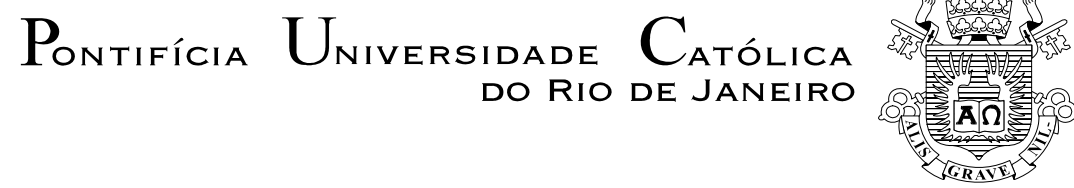

Fabrício Toledo de Souza

A crise do refúgio e o refugiado como crise

Tese de Doutorado

Tese apresentada como requisito parcial para obtenção do grau de Doutor pelo Programa de PósGraduação em Direito do Departamento de Direito da PUC-Rio.

Orientador: Prof. Francisco de Guimaraens Co-orientador: Prof. Adriano Pilatti 


$$
\text { Pontifícia Universidade } \text { Católica }_{\text {Do Rio de Janeiro }}
$$

Fabricio Toledo de Souza

\section{A crise do refúgio e o refugiado como crise}

Tese apresentada como requisito parcial para a obtenção do grau de Doutor pelo Programa de Pós-Graduação em Direito do Departamento de Direito da PUC-Rio. Aprovada pela Comissão Examinadora abaixo assinada.

Prof. Francisco de Guimaraens Orientador Departamento de Direito - PUC-Rio

Prof. Adriano Pilatti Co-orientador Departamento de Direito - PUC-Rio

Prof $^{a}$. Bethânia de Albuquerque Assy Departamento de Direito - PUC-Rio

Prof. Roberto Vilchez Yamato PUC-Rio

Prof. Alexandre Fabiano Mendes UERJ

Prof $^{\mathrm{a}}$ Angela Mercedes Facundo Navia

Profa ${ }^{\text {. Monica Herz }}$ Vice-Decana de Pós-Graduação do Centro de Ciências Sociais - PUC-Rio

Rio de Janeiro, 12 de setembro de 2016. 
Todos os direitos reservados. É proibida a reprodução total ou parcial do trabalho sem autorização da universidade, do autor e dos orientadores.

\section{Fabrício Toledo de Souza}

Graduou-se em Direito na Universidade Presbiteriana Mackenzie, em 1994. Mestre em Comunicação (Mídia e Mediações Socioculturais) pela Escola de Comunicação da Universidade Federal do Rio de Janeiro, em 2011. Doutor em Direito (Teoria do Estado e Direito Constitucional) pela Pontifícia Universidade Católica do Rio de Janeiro, em 2016. Realizou estágio de doutorado em período sanduíche na Birkbeck School of Law (University of London).

Ficha Catalográfica

\section{Souza, Fabrício Toledo}

A crise do refúgio e o refugiado como crise/ Fabrício Toledo de Souza; orientador: Francisco de Guimaraens. Departamento de Direito. Rio de Janeiro, 2016.

$$
\text { v., 204f,: il.; } 29,7 \mathrm{~cm}
$$

Tese (Doutorado) - Pontifícia Universidade Católica do Rio de Janeiro. Departamento de Direito.

Inclui referências bibliográficas.

1 Direito - Teses. 2. Direito de Refúgio. 3. Crise de Refugiados. 4. Migração 5. Fluxos. 6. Biopoder. 7. Fuga. 8. Resistência. I. Guimaraens, Francisco de. II. Pontifícia Universidade Católica do Rio de Janeiro. Departamento de Direito. III. Título. 
É realmente pequena a contribuição que posso fazer,

e pouco o que posso dedicar a quem quer que seja. Aproveito as páginas solenes desta tese para homenagear nossos companheiros e companheiras que estão fugindo e a todos nós, pessoas que sentiram medo e mesmo assim ousaram fugir. 


\section{Agradecimentos}

Impossível nomear e agradecer a todas as pessoas que me acompanharam neste percurso. Cito o nome de apenas algumas, pelo limite de espaço e tempo. Todas estas pessoas, dentre muitas outras, permitiram que eu tivesse a imensa alegria de realizar o doutorado. Mais que agradecimentos, gostaria de prestar minha homenagem a todas elas. E em especial a todas as pessoas com quem descobri o que é a fuga.

Agradeço à coordenação do Programa de Pós-Graduação em Direito da PUC-Rio e à Capes pelo apoio institucional e financeiro.

Agradeço especialmente ao Prof. Francisco de Guimaraens, pelo cuidado e atenção como orientador e pelas importantes lições de ética neste trajeto. Sou profundamente grato ao Prof. Adriano Pilatti, co-orientador, companheiro e mestre em muitas batalhas. Obrigado por me abrir as portas.

Agradeço ao amigo Charly Kongo, um dos mais ativos e interessantes pesquisadores que já conheci, pelas mais importantes lições nestes últimos anos.

Serei sempre grato a Sindia, por sua companhia diária, por seu amor ao mundo e por seu cuidado em cada gesto e palavra. Sem sua ajuda, não teria sequer ousado querer. Agradeço especialmente pela ajuda nas primeiras linhas da tese, no saudoso Toll Gate.

Agradeço à Profa. Angela Facundo, autora de uma das teses mais bonitas e interessantes sobre o tema do refúgio, por aceitar o convite e por toda a generosa interlocução. Agradeço à Profa. Bethania Assy, cujo incentivo e apoio foram fundamentais para que eu pudesse realizar o período de sanduíche. Ao companheiro e amigo Alexandre Fabiano Mendes, que há anos tem sido um dos meus maiores professores. Ao Prof. Roberto Yamato, pela constante interlocução, pelas dicas, orientações, e aulas em conjunto, e pelas grandes lições de vida. Agradeço ainda a Talita Tibola, pela curiosidade e delicadeza, e ao Prof. José María Gómez, por entrar nesta roubada sem saber. Pelas belas e densas lições e por toda gentileza. 
Sou especialmente grato à Profa. Patricia Tuitt por ter me recebido de maneira tão atenciosa em Birkbeck. Agradeço por todo o carinhoso apoio que me deu a Profa. Gisele Cittadino, fundamental para que eu pudesse levar adiante esta pequena jornada. Agradeço a Carmem e Anderson, pelo constante e paciente suporte. Sem eles, nada teria sido possível.

Sou grato a Aryadne Bittencourt, com quem experimentei e experimento os meus maiores êxodos. Por todo companheirismo, apoio e carinho. Pelos textos que fizemos juntos, pelos dias e noites lendo pareceres, pelas risadas pelas guerrilhas que inventamos. Pelas perdas e pelas vitórias.

Agradeço ao amigo Rafael Vieira, colega de doutorado, que se tornou um dos melhores professores que já tive. E a todos os amigos e amigas da PUC-Rio, com quem compartilhei momentos de grande alegria.

Nunca serei capaz de dizer a Giuseppe Cocco o quanto sou grato por sua generosidade. Por ter me convidado a experimentar pensamentos, experiências e alianças com tamanha alegria. Um mestre para toda a vida.

Sou muito grato aos companheiros e companheiras da Uninomade, em especial a Barbara Szaniceki, Bruno Cava, Clarissa Naback, Silvio Pedrosa, dentre tantas outras, autores e autoras fundamentais para os desafios presentes. Agradeço especialmente a Leonora Corsini, autora de uma tese que serve como inspiração e como chave.

Agradeço aos amigos e amigas do Núcleo Interdisciplinar de Estudos Migratórios (NIEM), em especial a Hélion Póvoa e a Regina Petrus, pelas várias oportunidades de interlocução. Agradeço a Charles Gomes e aos demais amigos e amigas da Casa Rui Barbosa.

Sou eternamente grato aos amigos e amigas da Cáritas do Rio de Janeiro, e em especial a Aline Thuller, pela paciência e generosidade. E a Cândido Feliciano, cujo apoio me permitiu iniciar e terminar este trabalho. Agradeço a Mireille Muluila, pelas diárias lições de força, coragem e delicadeza. A todas as pessoas de uma enorme lista com quem trabalhei no Setor de Proteção Legal nestes últimos oito anos. E, claro, a todas as pessoas que vieram dos mais diferentes mundos, que participaram da imensa confusão que é nosso cotidiano. 
Agradeço aos companheiros e companheiras de batalha. A Irmã Rosita Milesi, pela incansável luta e incrível solidariedade. Pelas tantas gentilezas, pelo permanente sorriso e por todas as acolhidas em Brasília. A Larissa Leite, Pablo Mattos, Rafael Marques, Natália Medina, Vivian Holzackher, Ricardo Félix, Gabriela Ferraz, Rafael Trabazo, Isabela Mazão, Gabriel Godoy, Thais Moraes, Virginius Lianza, Gabriela Tavares e a tantas outras pessoas com quem cruzamos caminhos.

Sou grato à Katie Jensen, pela amizade, solidariedade e companheirismo. Por me encorajar constantemente. Pelas lições, trocas e observações. Uma presença sempre constante, capaz de mudar nossos dias e nossas vidas. 


\section{Resumo}

Souza, Fabrício Toledo de; Guimaraens, Francisco de; A crise do refúgio e o refugiado como crise. Rio de Janeiro, 2016. 204p. Tese de Doutorado - Departamento de Direito, Pontifícia Universidade Católica do Rio de Janeiro.

A crise dos refugiados é apreendida em duas principais dimensões. De um lado, é a evidência de que a guerra tornou-se a condição generalizada de nosso tempo. Mais do que um evento extraordinário, a crise dos refugiados é signo da violência e da desigualdade como normalidade. Neste sentido, nomear como “crise” o aumento incessante dos deslocamentos é apenas uma forma de legitimar a violência constante em que vivem parcelas enormes da população mundial, especialmente as mais pobres. O fundamento humanitário do instituto do refúgio é indissociável da gestão global da iniquidade. Nesta primeira dimensão, qualificada como negativa, o instituto de refúgio, fundado em uma concepção de vida sempre diminuída, é apreendido como um dispositivo de controle e docilização. Por meio da distinção e classificação entre refugiados e migrantes, a vida, o direito e a cidadania surgem como bens escassos. De outro lado, sem recusar a tragédia, a crise surge em sua dimensão afirmativa. Nesta perspectiva, as classificações instituídas pelos estados cedem lugar às subjetividades produzidas pelos sujeitos que fogem. Os sujeitos em fuga afirmam o caráter constituinte e ontológico da fuga: atravessam a sobrevivência para afirmar a resistência como fundamento da vida, atribuindo, por meio de sua luta, o valor e a dignidade da própria vida. Simultaneamente à dor, à negatividade e à violência, na fuga existe o desejo positivo por liberdade e democracia. Os sujeitos decidem fugir porque querem viver. Não se trata de recusar a tragédia, mas sim recuperá-la do vazio e da impotência.

\section{Palavras-chave}

Direito de Refúgio; Crise de refugiados; Migração; Fluxos; Biopoder; Fuga; Resistência. 


\section{Abstract}

Souza, Fabrício Toledo de; Guimaraens, Francisco de (Advisor). The refugee crisis and the refugee as a crisis. Rio de Janeiro, 2016. 204p. Doctoral Thesis - Departamento de Direito, Pontifícia Universidade Católica do Rio de Janeiro.

The refugee crisis is considered in two main dimensions. On the one hand, it demonstrates that war has become the generalized condition of our time. More than an extraordinary event, the refugee crisis is a sign of the normalization of violence and inequality. In this regard, naming as a "crisis" the incessant increase of displacement is a way of legitimizing the constant violence in which large portions of the world population live, especially the poorest. The humanitarian foundation of the institution of refuge is inseparable from the global management of iniquity. In this first dimension, qualified as negative, the refuge regime, founded on a conception of always diminished life, is treated as a mechanism of control and docilization. Through the distinction and classification of refugees and migrants, life, rights and citizenship arise as scarce goods. On the other hand, without rejecting this tragedy, the affirmative dimension of the crisis is considered. In this perspective, the classifications established by states give way to the subjectivities produced by the fleeing subjects. They affirm the constitutive and ontological character of the escape: through survival, subjects in escape assert resistance as the foundation of life, giving, through their very struggle, value and dignity to life itself. Concomitant to the pain, negativity and violence, in escape there is a positive desire for freedom and democracy. Escaping subjects decide to flee because they want to live. This is not to deny the tragedy, but reclaim escape from emptiness and impotence.

\section{Keywords}

Refugee law; Refugee crisis; Migration; Escape; Resistance; Subjects in escape. 


\section{Sumário}

Introdução

1.A Crise dos refugiados e o refugiado como crise

1.1.A crise como tragédia e a crise como retórica 23

1.2.As fronteiras da crise 25

$\begin{array}{ll}\text { 1.3.A crise renovada e atualizada } & 27\end{array}$

1.4. História e genealogia da crise $\quad 29$

1.5.Os refugiados no sul do mundo 33

1.6.Gestão global dos fluxos $\quad 37$

1.7.Verdade, poder e a palavra dos refugiados 39

1.8.0 processo de refúgio no Brasil 40

1.9.Distinção entre refugiado e migrante: a vítima inocente 43

2.Direito de refúgio e a vida como fundamento 46

2.1.A crítica ao paradigma humanitário: a vida diminuída 47

2.2.A ascensão da vida ao centro da política 48

2.3.O Estatuto do refugiado e o estatuto da exceção 52

2.4.A vítima como paradigma e o governo da compaixão 56

2.5.A inocência e o corpo no limite 58

2.6.0 espetáculo das vítimas e os bastidores da guerra 60

2.7.Sofrimento como paradigma e a dissimulação das desigualdades 64

3.Razões humanitárias e gestão global dos refugiados 66

$\begin{array}{ll}\text { 3.1.Desigualdade como regra } & 67\end{array}$

3.2.Entre Dadaab e Calais: o campo e o vácuo como paradigmas 70

3.3.Os campos na fronteira: nem dentro, nem fora da lei 76

3.4.O "campo" de Brasiléia: a solução humanitária para os haitianos 79

3.5.A "crise" dos haitianos, a diáspora e o campo 82 
4.A verdade como escassez e raridade $\quad 87$

4.1.A decisão sobre refúgio no Brasil 90

4.2.A desconfiança como método 95

5.Guerra, biopoder e soberania 103

5.1.A crise "contra" a democracia 104

5.2.A crise ilimitada e incessante: exceção como normalidade $\quad 106$

5.3.A soberania imperial e a guerra global 107

5.4.Violência legítima e o paradigma da segurança 112

5.5.Estados de violência e a segurança dos viventes 115

5.5.Cálculo dos riscos e controle dos fluxos 119

$\begin{array}{ll}\text { 6.A guerra contra os refugiados } & 120\end{array}$

6.1.A crise dentre as crises: os refugiados na África 121

6.2.América Latina, guerra e instabilidade 123

6.3.Oriente Médio e o conflito sírio 125

6.4.A exceção como paradigma: a crise dos refugiados na Europa 126

6.5.A crise da gestão: acordos para controle de fronteira 131

$\begin{array}{ll}\text { 7.A crise da soberania. Europa como paradigma } & 137\end{array}$

7.1.A Fortaleza Europeia e a polícia como governabilidade $\quad 144$

7.2.Choque de civilizações ou a civilização em choque 149

8.0 Congo como paradigma: no coração das trevas. 155

8.1.A diáspora e a possibilidade de lutar 156

8.2.Repressão política e opressão 160

8.3.A luta por direitos humanos no Congo: a coragem da verdade 162

8.4.Ciclos de uma guerra sem fim 164

8.5.Modulações da guerra 169

8.6.Operação "Likofi" e o massacre de crianças 170

9.Dimensão afirmativa da crise 175

9.1.Pós-modernidade, êxodo e subtração 177

9.2.Insubmissão, desutopia e libertação 180

9.3.Exceção como potência: a vida como excedente 182 
$\begin{array}{ll}\text { 9.4.A vida maior contra a sobrevivência } & 187\end{array}$

9.5.Cidadania como potência e o direito dos mais fortes 189

10.Conclusões 192

11.Referências bibliográficas 199 


\section{Introdução}

“É preciso continuar. Eu não posso continuar, eu vou

continuar".

Samuel Beckett ${ }^{1}$.

Assumimos a crise como um fato e como o ponto de partida para elaborar uma crítica à própria definição de refugiado. E, desta forma, queremos aprofundar o sentido de crise para vê-la desdobrar-se em vários sentidos. Partimos do pressuposto de que o instituto de refúgio não apenas vive incessantes crises, mas está ele mesmo instituído como uma crise: primeiro, porque a figura do refugiado nos prova que a positivação dos direitos dos refugiados e dos chamados direitos humanos nunca foi suficiente para garantir a sua proteção.

Segundo, porque a existência dos refugiados assinala também expressão da crise do próprio conceito de estado como o conhecemos e, desta forma, a crise é, na verdade, o nome do contínuo esforço de recomposição violenta das hierarquias e dos comandos. Neste sentido, a crise é expressão da arbitrariedade das fronteiras e da burocracia. E terceiro, o que nos parece mais grave, é que o fundamento humanitário do instituto do refúgio é indissociável da gestão global da iniquidade: não apenas dispositivos que bloqueiam fluxos, mas, sobretudo, que definem e liberam novos fluxos: fluxo de corpos docilizados, de mão-de-obra barata, de trabalhadores subordinados, além do fluxo de investimentos em cercas, em armas e consultores.

Para elaborar uma crítica ao instituto de refúgio, percorremos duas perspectivas, que são ao mesmo tempo teóricas e éticas: de acordo com a primeira, o instituto de refúgio é tomado como um dispositivo de gestão e controle dos fluxos. Nesta primeira perspectiva, que qualificamos como negativa ou reativa, o instituto de refúgio tem por principal produção a distinção entre migrantes e refugiados, mas também entre refugiados e solicitantes de refúgio. É o

\footnotetext{
${ }^{1}$ BECKETT, Samuel. “O Inominável”. Rio de Janeiro: Ed. Globo, 2009.
} 
dispositivo de gestão e de controle dos fluxos, que valoriza em especial a escassez da vontade e da vida. Os refugiados são os que não tiveram escolha, enquanto os migrantes possuem a opção livre de decidir.

Não se trata evidentemente de ignorar a terrível d

iferença. Ao contrário, trata-se de verificar as nuances. E, acima de tudo, de recusar o fundamento da distinção: não para dizer que os migrantes tampouco puderam escolher, como acontece com grande parte das pessoas que deixam sua cidade em razão da miséria, da fome, da violência e de outras formas de opressão. Recusamos a distinção para dizer que os refugiados e deslocados forçados em geral também decidem. E decidem viver.

De acordo com esta segunda perspectiva, que qualificamos como afirmativa, apreendemos o direito como terreno das lutas e das forças sociais, o que significa reconhecer a fuga e o êxodo como forças constituintes do direito. E o sujeito em fuga como a subjetividade que recusa as tradicionais classificações binárias e antagonistas - migrante ou refugiado, refugiado inocente ou falso solicitante - e que também qualifica positivamente o gesto de fugir, atribuindo o valor daquilo que seria a vida e a sua dignidade.

Insistimos no caráter afirmativo do movimento de fuga porque, de nosso ponto de vista e do ponto de vista de ativistas e teóricos com os quais compartilhamos alguns conceitos e pressupostos, ela é dor, sofrimento e recusa, mas, ao mesmo tempo, afirmação do desejo por libertação, segurança e justiça. Dentro desta perspectiva, pretendemos também afirmar o caráter constituinte e ontológico da fuga. Isso significa sustentar o caráter antecedente e constituinte da fuga, e, em seguida, o direito como terreno imanente à resistência dos refugiados e dos migrantes. E, por fim, tomar o sujeito em fuga como produção subjetiva deste gesto de recusa e afirmação. A fuga como processo de constituição de um sujeito que atravessa a sobrevivência para afirmar a resistência como fundamento da vida.

Se do ponto de vista dos estados, o estatuto dos refugiados significa dar proteção e cidadania às pessoas obrigadas a fugir - e certamente elas precisam de tal amparo - do ponto de vista da resistência, os refugiados e migrantes pretendem ao estatuto de cidadania global e, por isso, no atual ciclo de lutas - também chamada de "crise dos refugiados" - eles não são o triste saldo dos massacres e guerras, mas são os sujeitos que determinam a crise, em sua dimensão 
constituinte. A crise é a emergência de uma cidadania global e de uma globalização de singularidades.

Aceitamos a crise, como se pode ver no primeiro texto da pesquisa, e a assumimos em toda sua profundidade: uma crise para as vítimas e para os sobreviventes e, em sequida para os deslocados, refugiados e migrantes que vivem precariamente nas periferias do mundo, na incerteza quanto ao seu futuro. A outra expressão da crise diz respeito à distribuição desigual da "crise" no mundo: as populações das partes mais pobres sofrem com as guerras e suportam os ônus dos deslocamentos, com a chegada massiva de pessoas fugindo e com o esvaziamento de suas próprias cidades. E quando decidem fugir em direção aos países onde a democracia é anunciada como um modelo para o mundo, são violentamente perseguidas, justamente porque estão fugindo. E porque colocam em risco as diversas fronteiras que definem as hierarquias.

As fronteiras que separam o refugiado, o solicitante de refúgio e o migrante são os traços desta crise. Em vez de criticar os supostos acidentes, tratamos de criticar exatamente o êxito dos dispositivos. A distribuição desigual, a distinção racial e a escassez são constantemente produzidas e ampliadas, como forma de manutenção das fronteiras e das divisões globais. A distinção é também simultânea à perseguição das pessoas, justamente em razão de sua fuga. Distinção realizada através de critérios raciais e com pretensões de demarcar novos signos biopolíticos: o refugiado e o migrante se tornam novas representações raciais.

Queremos assinalar, neste primeiro texto, que a retórica da escassez, utilizada para justificar a distinção entre migrantes e refugiados, é expressão direta da governabilidade. Mesmo no Brasil, onde é irrelevante o número de solicitantes de refúgio, os dispositivos de distinção são tão arbitrários quanto em países onde os números são muito maiores. O que importa, deste ponto de vista, é aprimorar os dispositivos, acentuar as distinções e recompor a divisão e as iniquidades.

Depois de tratar brevemente sobre o histórico do instituto de refúgio e de algumas de suas linhas genealógicas, apontamos alguns das iniciativas adotadas pelos estados do continente africano e latino-americano para elaborar uma nova definição de refugiado, em acordo com os problemas e desafios da região, fugindo, assim, das restrições que a definição europeia determinava. A despeito de todos os esforços e a despeito de todas as particularidades, a definição de refugiado mantém-se distante da realidade das pessoas que necessitam de amparo. 
E, por fim, apontamos como o processo de refúgio, inclusive no Brasil, está baseado quase exclusivamente sobre a análise da credibilidade dos solicitantes de refúgio. A palavra dos refugiados é validada apenas como peça processual e somente depois de verificada sua credibilidade. Perscrutada por especialistas e julgadores aos quais são atribuídos poderes para definir a verdade, a palavra dos refugiados será sempre objeto dos dispositivos de saber e poder. E terão validade apenas depois de homologadas, de forma que possam retornar aos indivíduos, subjetivando-os como vítimas inocentes.

No segundo texto, por meio da crítica ao fundamento "humanitário" do instituto de refúgio, queremos demonstrar que a vida colocada sob proteção é a vida em sua qualidade mais fraca. O estatuto político do refugiado é o estatuto fundado na sobrevivência ou na quase-vida, a vida diminuída em sua potência de resistir. Aquela vida que o filósofo Giorgio Agamben denomina de "vida nua”. A vida se tornou, por excelência, o lugar onde incide e investe o poder e onde estão as resistências. É a vida diminuída, como quase-vida, que se torna o fundamento da proteção. Por consequência, a cidadania, de acordo com o governo "humanitário", pode ser concedida apenas àqueles que se apresentam e se confessam como vítimas.

Trata-se, como já havia demonstrado Michel Foucault, da história que começa com a ascensão da vida ao centro da política na transição do regime disciplinar para o regime do biopoder. Em vez do poder decidindo pela morte, como ocorria na soberania clássica, o biopoder que decide a vida. Na soberania do biopoder, o direito de fazer morrer cede lugar ao fazer viver. Contudo, o investimento do poder sobre a vida não é um investimento qualquer, mas é, acima de tudo, um modo de expropriação das forças vitais. E, de modo paradoxal, é no regime do biopoder em que se dão as mais terríveis guerras. Travadas não mais em nome do soberano, mas em nome da existência da espécie. Numa reviravolta, a sobrevivência da humanidade fundamenta a possibilidade de extermínio total pelo poder das armas atômicas.

Na sequência das análises de Foucault, Giorgio Agamben toma a questão da politização da vida para demonstrar que a nudez da vida surge como momento decisivo da modernidade. Ao seu próprio modo, Agamben afirma a continuidade entre o poder soberano e o biopoder, especificamente a partir do ponto da incidência do poder sobre a vida nua. Agamben quer demonstrar que a vida 
biológica como fundamento da política prova justamente a continuidade do soberano arcaico: a decisão sobre a morte ainda é uma prerrogativa do poder. Conectando as investigações de Foucault com o trabalho de Hannah Arendt, Agamben pretende provar que os regimes contemporâneos de soberania e poder, incluindo o nazismo e a democracia liberal, apoiam-se sobre o mesmo conceito de vida nua.

Além das denúncias feitas por Foucault e Agamben quanto à ascensão da vida - ou da vida nua -- ao centro da política, há outros autores que formulam suas críticas a partir da eleição do sofrimento como fundamento para o direito e, portanto, da compaixão e da condescendência como fundamentos do sujeito político. Costas Douzinas, de uma parte, critica a retórica dos direitos humanos como uma “antipolítica”, ou como uma nova teologia de estado, cujo principal efeito é apagar as desigualdades responsáveis pelo sofrimento e pela violência. Didier Fassin, por sua vez, acusa o enfraquecimento da política e a transformação daquilo sobre o qual se fundava o "sujeito de direitos". O "humanitarismo" surge justamente neste regime de valorização do humano como vivente, como mera vida biológica. Em nossa crítica à natureza "humanitária” do direito de refúgio, ou ao seu componente biopolítico de docilização das forças de resistência, queremos demonstrar que tornar a vida como mera sobrevivência é neutralizá-la em sua capacidade de criar e resistir.

No terceiro texto, a crítica ao governo humanitário pretende atingir os aspectos mais globais da gestão dos refugiados. Como fala Didier Fassin, a gestão dos refugiados implica que, de um lado sejam mantidas as enormes massas indiferenciadas de pessoas, entre deslocadas e refugiadas, que serão abrigadas em tendas improvisadas e nas periferias das cidades, nas periferias do mundo. De outro, os solicitantes de refúgio que compõem os "fluxos mistos" e que tentaram a vida nas cidades do norte global, mas não sem antes passar por processos burocráticos, individuais e individualizantes, em que terão de convencer-nos de sua sinceridade. Cada uma delas será analisada meticulosamente, para que não se dê a alguém que não merece um status excepcional. É a retórica da escassez, justificada pela necessidade de se evitar a "banalização" do refúgio. Gestão da excepcionalidade.

Este sistema, que mantém os refugiados dos campos (no sul) longe do acesso à possibilidade de se tornarem solicitantes de refúgio (no norte), é 
construído através de fronteiras legitimadas pela retórica da exceção (as crises) e da escassez (de direitos e de recursos). Neste sentido, seguindo ainda os passos de Didier Fassin, apontamos como paradigma não os campos, mas aquilo que está entre "entre" os campos e os solicitantes de refúgio, como é o caso do acampamento de Calais, na França, e o abrigo de Brasileia, no Brasil.

A propósito, tomamos a "crise" dos haitianos no Brasil como perfeita ilustração das ambiguidades e das ambivalências da gestão humanitária no Brasil. Primeiro, porque a chegada dos haitianos expôs os métodos perversos de seleção e utilização de mão-de-obra "barata” no Brasil. E, segundo, porque a estabilidade no Haiti é garantida pela presença militar brasileira, graças à experiência que conseguiram na "pacificação” das periferias no Brasil. E a experiência acumulada no Haiti é utilizada nas novas experiências de estabilização dos pobres, como acontece nas favelas do Rio de Janeiro.

No quarto texto, tentamos demonstrar, através de casos reais, como se analisa a verdade em algumas solicitações de refúgio. Nossa preocupação não é definir uma amostra que possa servir de base para uma análise crítica, mas demonstrar, através de algumas decisões, os critérios utilizados para julgar a sinceridade e credibilidade dos solicitantes de refúgio, através de processos individuais. Fazemos referência a casos julgados pelo governo do Reino Unido e analisado pelas organizações de direitos humanos “Anistia Internacional” e "Still Human Still Here”, em relatório publicado em 2013. Sem qualquer pretensão de promover um estudo comparado entre os modelos de decisão, nosso objetivo é demonstrar a semelhança entre os critérios e as decisões, aproveitando, por um lado, a transparência permitida pelo governo britânico e, por outro, nosso acesso aos processos no Brasil, graças à nossa atuação na defesa de alguns casos.

No quinto texto, a crise é apreendida em seu sentido mais trágico. O regime da soberania do biopoder é também o regime da guerra generalizada e global. É a condição diária em que vivemos. Falar em guerra, nestes termos, significa, por um lado, ampliação e expansão dos conflitos, por outro, a intervenção policial como forma de controle social. É a guerra em suas duas dimensões: ao mesmo tempo, conflito e policiamento, local e global. Acompanhamos, assim, as análises de Hardt e Negri (2005), sobre a "soberania imperial” e o estado de guerra global, e o conceito de “estados de violência”, desenvolvido por Frédéric Gros (2009), para 
quem as guerras e a violência são justificadas em nome da preservação dos viventes e em defesa das vítimas.

Neste estado de violência geral normalizada, que a guerra convive com a gestão policial permanente, os inimigos são incessantemente inventados e a violência contra eles é legitimada a posteriori. Em outros tempos, a "ameaça comunista” foi uma das expressões do inimigo invisível contra a soberania. Hoje, os migrantes e refugiados são anunciados como risco. Em parte, por causa da imagem onipresente e onipotente da ameaça terrorista, mas também porque são imaginados como desvios da normalidade e risco à segurança e estabilidade interna. Do ponto de vista dos estados, o refúgio é uma brecha nos dispositivos de regulação de mobilidade e, portanto, uma anormalidade a ser constantemente corrigida e vigiada.

O regime de guerra total, entretanto, não se resume à destruição e morte generalizada. Não é este a sua produção principal. O regime da soberania do biopoder não pode produzir apenas pura morte, sob o risco de eliminar a vida que lhe serve como fonte de existência. Seguindo as lições de Michel Foucault, ressaltamos que o poder não se resume a uma única e exclusiva concepção negativa ou de pura repressão. A hipótese não repressiva, proposta por Foucault, e desenvolvida, em outros termos, por Gilles Deleuze e Felix Guatarri, anuncia uma concepção de poder que passa pelo desejo. O poder, enfim, produz positividade. E produz, inclusive, um determinado conceito de refugiado.

Como uma confirmação trágica do que apresentamos no texto anterior, o sexto texto apresenta a crise dos refugiados a partir de fatos concretos. A crise que é especialmente grave para as populações das partes mais pobres do planeta, que arcam com as dores das guerras e com os ônus dos deslocamentos forçados. A Etiópia e a República Democrática do Congo, países que já enfrentam graves crises internas, incluindo conflitos sangrentos, fome e falta de liberdade, estão dentre os mais afetados economicamente pela chegada dos refugiados. Na América Latina, o conflito armado colombiano é responsável pelo deslocamento de 6,7 milhões de pessoas e pelo menos 360 mil reconhecidas como refugiadas em outros países, principalmente no Equador, o país da América Latina com maior número de refugiados. No Oriente Médio, a crise explodiu de modo particular, especialmente na Jordânia - onde foi criado o campo de Zaatari, com cerca de 80 
mil refugiados --, no Líbano, e outros países, incluindo Iraque, de onde há anos fogem milhares de pessoas.

Enquanto isso, a Europa se fecha para a crise, produzindo sua própria crise: de um lado, estendendo suas fronteiras por meio de acordos com a Turquia, na tentativa de conter o fluxo de refugiados, delegando a violência - e responsabilidade legal - para um governo conhecido pelas arbitrariedades. Em 2012, a União Europeia destinou à Turquia cerca de 20 milhões de euros para compra de equipamentos, com a condição de ter o "fortalecimento da capacidade de vigilância das fronteiras”. Entre 2007 e 2013, a União Europeia gastou quatro bilhões de euros para lidar com a questão dos refugiados, mas a maior parte dos recursos foi usada em militarização das fronteiras, criação de centros de detenção e nos processos de deportação.

A retórica da crise é a justificativa para o fechamento das fronteiras na Europa, para a violência policial e outras medidas arbitrárias contra os refugiados, incluindo detenção e o confisco de bens. O sétimo texto prossegue na descrição do recrudescimento no tratamento dos refugiados no continente europeu. O que nos interessa nestes acontecimentos, entretanto, não é confirmar, nem desmentir a crise de refugiados na Europa. De um modo ou de outro, a crise é real e inegável. Nem tampouco nos interessa tornar estes eventos paradigmas do sofrimento dos refugiados no mundo.

O que nos interessa, em primeiro lugar, é tomar esta crise na relação e conexão com as outras crises. Em certo sentido, não há fluxo de refugiados que não seja globalmente conectado a outros. A violência contra os refugiados nos países do norte está conectada às mortes no Mediterrâneo, às arbitrariedades na Turquia, ao esgotamento dos recursos na Etiópia e inclusive no aumento de refugiados no Brasil. E, acima de tudo, está crise diz respeito ao esforço pela recomposição de uma identidade majoritária ameaçada. Neste sentido, a crise europeia nos mostra a crise de um modelo e o funcionamento da governabilidade em termos globais.

E se a violência contra os refugiados nos revela a crise europeia como paradigma da guerra como regulação social, o conflito no Congo é o paradigma da guerra em sua dimensão mais terrível. É sobre este tema que trata o oitavo texto. A face mortífera da soberania do biopoder. Mesmo no Congo, contudo, a guerra é também o modo de normalização e repressão social. Se partes do país são 
atingidas por conflitos bélicos, outras sofrem com a ação de um governo policial e tirânico: prisão de opositores políticos, jornalistas, ativistas de direitos humanos, dentre outras arbitrariedades, incluindo cerceamento de liberdade e da livre escolha dos representantes políticos. Uma guerra que é local e global, em que estão em jogo a vida de mulheres e crianças, e também os valiosos recursos minerais utilizados pelas grandes empresas de eletrônicos.

Por fim, no último texto, de número nove, tratamos da crise em sua dimensão afirmativa: Uma afirmação que não pacifica a dor e o sofrimento, mas ainda assim se faz produção de vida. Trata-se da crise determinada pelos sujeitos em fuga e que tem a liberdade dos sujeitos - ou sua luta por libertação, sem utopias, mas repleta de desejos e sonhos - como objetivo e causa. A crise, deste ponto de vista, diz respeito a uma ontologia que não apenas subsiste, mas recusa e conjura qualquer condescendência e piedade. Afasta toda negatividade. 


\section{A Crise dos refugiados e o refugiado como crise}

“A libertação não é um fim, mas um começo”.

Antonio Negri ${ }^{2}$.

A “crise” dos refugiados é oficialmente declarada “crise” pelo Alto Comissariado das Nações Unidas para Refugiados (ACNUR), certamente a maior autoridade global no assunto. O ACNUR contabilizou, ao final de 2014, 59,5 milhões de pessoas fugindo de perseguições ou conflitos, o maior desde o fim da Segunda Guerra Mundial. Em termos globais, foram contabilizadas 19,5 milhões de pessoas refugiados, 38,2 milhões de deslocados dentro de seus próprios países e 1,8 milhão de solicitantes de refúgio. Sem contar os mais de cinco milhões de refugiados palestinos que há décadas vivem nos 58 campos de refugiados organizados pela UNRWA ${ }^{3}$. A crise tem também um dado que a torna ainda mais trágica: metade dos refugiados no mundo é formada por jovens e crianças de até 18 anos de idade ${ }^{4}$.

No ano anterior, quando a crise já era anunciada como a maior das últimas décadas, havia 51,2 milhões de pessoas buscando proteção, dentre as quais, 33 milhões de deslocadas internas, 16,7 milhões reconhecidas como refugiadas e pouco mais de um milhão aguardando resposta ao seu pedido ${ }^{5}$. O mais recente relatório do ACNUR mostra que as populações de pessoas refugiadas e

\footnotetext{
${ }^{2}$ NEGRI, Antonio. “Jó, a força do escravo”. p. 35. Editora Record; Rio de Janeiro, 2002.

${ }^{3}$ United Nations Relief and Works Agency for Palestine Refugees in the Near East ou, em tradução livre, Agência das Nações Unidas de Assistência aos Refugiados da Palestina no Oriente Próximo.

4 "Relatório do ACNUR revela 60 milhões de deslocados no mundo por causa de guerras e conflitos”. Acnur. 18/06/2015 (Disponível em http://www.acnur.org/t3/portugues/noticias/noticia/relatorio-do-acnur-revela-60-milhoes-dedeslocados-no-mundo-por-causa-de-guerras-e-conflitos/) (Último acesso em 05/06/2016) e "World at war: UNHCR global trends. Forced displacement in 2014". UNHCR. (Disponível em http://www.unhcr.org/556725e69.pdf) (Último acesso em 05/06/2016).

5 "War human cost. UNHCR Global Trends 2013". UNHCR. (Disponível em http://unhcr.org/trends2013/) (Último acesso em 05/06/2016).
} 
deslocadas internamente cresceram em todas as regiões do mundo e que nos últimos cinco anos, pelo menos 15 conflitos se iniciaram ou foram retomados: oito na África (Costa do Marfim, República Centro Africana, Líbia, Mali, Nigéria, República Democrática do Congo, Sudão do Sul e Burundi); três no Oriente Médio (Síria, Iraque e Iêmen); um na Europa (Ucrânia); e três na Ásia (Quirguistão e em diferentes áreas de Mianmar e Paquistão). Os conflitos no Afeganistão, Somália, República Democrática do Congo, dentre outros, lançam milhões de deslocados em campos improvisados (ainda que improvisados por décadas), nas periferias das cidades e na incerteza quanto seu futuro próximo.

O conflito na Síria, com mais de 400 mil vítimas fatais e cerca de 4,8 milhões de pessoas refugiadas até o ano passado ${ }^{6}$, é considerado a principal crise das últimas décadas, com impactos em muitos países no mundo, incluindo o Brasil. No entanto, é principalmente nos países vizinhos que a crise síria denuncia sua gravidade. A Turquia abriga 2,5 milhões de refugiados sírios, o Líbano, cerca de 1,14 milhão, a Jordânia tem 635 mil e Iraque (onde 3,9 milhões de iraquianos são deslocados internos em razão do longo conflito no país), tem 245 mil e o Egito, 117 mil sírios ${ }^{7}$.

\section{1}

\section{A crise como tragédia e a crise como retórica}

São os países pobres ou "em desenvolvimento" que arcam com quase todo o ônus, embora a crise seja sempre anunciada como uma crise dos estados ricos do norte global: cerca de 14 milhões de refugiados e mais de 30 milhões de deslocados internos estão distribuídos em diferentes países da África Subsaariana e do Oriente Médio. De outro lado, pouco menos de um milhão de pessoas buscaram refúgio na Europa durante 2015. Ao mesmo tempo, cresce, a cada ano, o número de pessoas que se arriscam nas perigosas jornadas pelo Mediterrâneo, no Golfo de Áden, no Mar Vermelho e no Sudeste da Ásia. Durante 2015, 911 mil

\footnotetext{
6 “Syria Regional Refugee Response” Inter-agency information sharing portal. UNHCR. 01/06/2016 (Disponível em http://data.unhcr.org/syrianrefugees/regional.php) (Último acesso em 05/06/2016).

7 "Syria's refugee crisis in numbers". Anistia Internacional. 03/02/2016. (Disponível em https://www.amnesty.org/en/latest/news/2016/02/syrias-refugee-crisis-in-numbers/) (Último acesso em 05/06/2016).
} 
pessoas chegaram à Europa por mar, enquanto 3.550 perderam a vida durante a jornada. Dentre os que tiveram a sorte de chegar com segurança, a maioria (cerca de 75\%) fugiram de perseguições ou de conflitos na Síria, Afeganistão e Iraque ${ }^{8}$.

Em termos de custo econômico e social, a crise é sobretudo uma crise para os países mais pobres. Se Turquia, Líbano, Jordânia e outros países do Oriente Médio sofrem com o pesado ônus da chegada massiva de refugiados sírios, países pobres como Etiópia, Uganda, República Democrática do Congo, Chade e Quênia estão entre os mais impactados economicamente pela crise dos refugiados ${ }^{9}$. A Etiópia, com 400 mil crianças em situação de má nutrição aguda e mais de 10 milhões de pessoas carentes de ajuda alimentar ${ }^{10}$, é o país economicamente mais afetado pela chegada de refugiados.

No continente mais pobre do mundo, onde persiste um dos mais longos conflitos da história, cerca de 1,2 milhões de pessoas se dispersaram fugindo da guerra na República Democrática do Congo, que deslocou mais de um milhão de pessoas apenas para os países vizinhos, enquanto 3,8 milhões vivem deslocadas dentro do país ${ }^{11}$. O mesmo país que recebeu, no decorrer dos anos 1990, centenas de milhares de pessoas fugindo da guerra civil em Angola, do genocídio de Ruanda, dos conflitos na República Centro Africana e no Burundi. Em outro pedaço pobre do sul global, o conflito colombiano provocou 40 mil mortos, 6,7 milhões de deslocados e 360 mil refugiados, sem contar as centenas de milhares que ainda aguardam uma solução. É a segunda maior crise de deslocados internos do mundo depois da Síria ${ }^{12}$.

Trata-se inegavelmente de uma crise. Em primeiro lugar, para as famílias dos mortos e para os mutilados; para os sobreviventes que se escondem dentro do

8 “2015: the year of Europe's refugee crisis”. UHNCR. 2015. (Disponível emhttp://tracks.unhcr.org/2015/12/2015-the-year-of-europes-refugee-crisis/) (Último acesso em 05/06/2016).

${ }^{9}$ De acordo com o relatório oficial do ACNUR “Mid Year Trends - June 2015”. (Disponível em http://www.unhcr.org/56701b969.html) (Último acesso em 07/04/2016).

10 "Ethiopia drought 'as bad for children as Syria's war'. Al Jazeera. Charles Stratford. 17/01/2016. (Disponível em http://www.aljazeera.com/news/2016/01/ethiopia-drought-prompts-globalappeals-aid-160117143110259.html). (Último acesso em 26/01/2016)”.

11 "Democratic Republic f the Congo: A migration history marked by crises and restrictions". Migration Policy Instituto. 20/04/2016. Marie-Laurence Flaxaus e Bruno Schoumaker. (disponível em http://www.migrationpolicy.org/article/democratic-republic-congo-migration-history-markedcrises-and-restrictions) (Último acesso em 13/05/2016).

12 “ACNUR pede que refugiados sejam ouvidos em negociações de paz na Colômbia”. ONUBR Nações Unidas no Brasil. 12/04/2016 (Disponível em https://nacoesunidas.org/acnur-pede-querefugiados-sejam-ouvidos-em-negociacoes-de-paz-na-colombia/) (Último acesso em 14/05/2016) 
próprio país e para os que habitam as tendas improvisadas; para os que cruzam florestas, mares e desertosem busca de paz; para os que superam as cercas erguidas em diversas partes do mundo e para os que agora estão recolhidos em centros de detenção. E para os que vivem nas periferias do mundo, com documentos precários, na incerteza quanto ao seu futuro. Para todas estas pessoas, a crise é inegável e ela prova que a violência mais arcaica sobrevive a todos os avanços tecnológicos, a todas as boas intenções, às conquistas da civilização e acordos de paz. E ela evidencia que as guerras foram trazidas para dentro das fronteiras de cada estado, variando de intensidade, seja como guerra civil, intervenção militar, contra-insurgência ou simplemente como ação "pacificadora” de polícia. De qualquer modo, a guerra é a condição generalizada em que vivemos, simultaneamente local e global, e ainda maior e mais violenta do que já foi antes.

A outra dimensão da crise diz respeito à sua distribuição desigual no mundo e à reiterada iniquidade quanto aos custos da guerra. As populações das partes mais pobres arcam com o ônus das guerras - sempre brutais e invisíveis -- ao mesmo tempo em que suportam o custo dos deslocamentos, com a chegada massiva de pessoas fugindo de outras guerras perseguições. E quando uma parte insignificante deste fluxo parte em busca da paz, da segurança e dos direitos humanos prometidos pelas nações democráticas da parte mais rica do globo, eis então uma nova dimensão da crise e também uma nova dimensão da guerra: os refugiados são eles mesmos nomeados como crise e a guerra é movida também contra eles, apenas e justamente porque ousaram fugir da miséria que lhes era reservada como destino.

\section{2}

\section{As fronteiras da crise}

A “crise dos migrantes" -- este outro nome que se deu ao massacre contra as pessoas que decidiram atravessar a fronteira entre o sul e o norte, sejam eles nomeados refugiados, migrantes ou deslocados, todos estes sujeitos em fuga -- é o nome da crise em termos de exceção e escassez, através da produção de uma falsa imagem de invasão, risco e insegurança. Quando os próprios refugiados não são diretamente criminalizados, nomeados como "falsos solicitantes", "migrantes 
ilegais" ou "indocumentados", a eles são associadas à figura do "coiote” ou do traficante de pessoas. $\mathrm{O}$ fato terrível, sem que se faça qualquer segredo quanto a isso, é que eles passaram a ser perseguidos em razão de sua fuga, isto é, são perseguidos justamente por terem desejado fugir. A perseguição contra os refugiados - os sujeitos em fuga - é também uma perseguição motivada por critérios raciais ${ }^{13}$ : um mecanismo biopolítico que não apenas distingue racialmente, mas que pretende marcar e criar incessantemente novas distinções, de forma que hoje o "migrante” e o "refugiado" já sejam consideradas classificações raciais. O refugiado e o migrante não apenas são figuras associadas às minorias raciais, como se tornam, elas mesmas, novas representações raciais.

As fronteiras entre o refugiado, o solicitante de refúgio e o migrante são hoje os traços desta crise. Não faltam críticos a apontar as terríveis consequências dessa crise, mas elas se limitam, em geral, a acusar a insuficiência de recursos e direitos ou uma suposta distorção ou corrupção do sistema, como se ele estivesse contaminado por distúrbios externos ou influências exteriores. Em vez disso, trata-se de criticar exatamente o seu sucesso: o que chamamos de falhas fazem parte essencial do funcionamento ambíguo e ambivalente do sistema de refúgio, como parte da gestão dos dispositivos. Ao mesmo tempo, proteção humanitária e produção de distinção. A distribuição desigual, a distinção racial e a escassez são constantemente produzidas e ampliadas, como forma de manutenção da fronteira entre o refugiado que vive as guerras no sul global e o solicitante de refúgio que pretende a paz prometida pelo norte. E, ao mesmo tempo, como um modo de acréscimo aos dispositivos de segurança e controle conectados e agenciados ao sistema de refúgio.

A nomeação e a decisão sobre quem é e quem não é refugiado demonstra de maneira clara como o regime de "exceção" é a outra face da governabilidade do biopoder. A exceção tornada regra e normalidade. E a guerra, em vez de exceção, transformada em condição geral de existência, assim como a exploração, a sujeição e a distribuição desigual de bens e direitos. A crise é a normalidade do regime de governo do biopoder. E não é preciso acreditar que a distinção seja parte de um sistema regular, estável e organizado rigidamente e de modo vertical:

${ }^{13}$ FASSIN, Didier. “ La economia moral del asilo. Reflexiones críticas sobre la 'crisis de los refugiados’ de 2015 em Europa”. Revista de Dialectologia y Tradiciones Populares. Vol. LXX, n.2, pp.277-290, julho-dezembro 2015. 
mesmo nos países do sul, como o Brasil -- onde o número de refugiados e de solicitantes de refúgio, a despeito do enorme crescimento nos últimos anos, é irrelevante em termos absolutos e relativos (proporcionalmente ao total da população e em termos de impacto social e financeiro) -- os dispositivos de distinção podem ser tão rígidos, brutais e arbitrários quanto na Turquia, no Reino Unido ou na França.

Nas nuances e ambivalências da crise, a fuga é o enigma a disputar. A fuga da vítima inocente, forçada a deixar sua casa, absolve o sujeito com o estatuto jurídico e moral de "refugiado". Maculado pelo desejo de uma vida melhor, os migrantes, por sua vez, são tratados como ameaça. Ao lado do refugiado como vítima inocente, o único absolvido por fugir, de acordo com as regras da economia moral ${ }^{14}$ de cada tempo, há o refugiado “mentiroso” e os migrantes. A despeito de se declarar refugiado e a despetido das infinitas nuances que habitam a fronteira entre as classificações, fugir é o nome do crime: fugir e desejar uma vida melhor.

\section{3}

\section{A crise renovada e atualizada}

A crise dos refugiados é sempre anunciada como algo extraordinário, uma emergência atípica ou uma excepcionalidade. E, de fato, a existência de mais de 50 milhões de pessoas em fuga seja mesmo um evento que denuncia a ruptura com o normal. O extraordinário está na própria dimensão contábil dos corpos dos corpos mortos, mutilados violentados e dos corpos em fuga - mas também na emergência de um evento inesperado ou incomum. As grandes guerras e revoluções do século XX, sobretudo a Segunda Grande Guerra, fez do refugiado o signo de um tempo, tendo por pressuposto ou condição implícita, contudo, que o refugiado era um evento determinado, com prazo para acabar.

\footnotetext{
${ }^{14}$ Referência ao conceito de "economia moral", que Didier Fassin desenvolveu no texto "La economia moral del asilo. Reflexiones críticas sobre la 'crisis de los refugiados' de 2015 em Europa”. Revista de Dialectologia y Tradiciones Populares. Vol. LXX, n.2, pp.277-290, julhodezembro 2015. Ele define economias morais como a "produção, circulação e apropriação de normas e obrigações, valores e afetos relativos a um problema específico em um tempo e espaço específicos” (p.279).
} 
A edificação de um grande sistema de refúgio logo após a Guerra parecia mais um sinal da disposição em demarcar e delimitar a memória do que propriamente a precaução para um futuro que se tornaria sombrio. Do ponto de vista dos refugiados, nem a eloquência das autoridades, nem a boa vontade das declarações de direitos, foram capazes de salva-los de um mundo em ruínas. As paredes, mesmo no mundo da declaração dos direitos humanos e da Convenção de 1951, continuaram a desabar sobre as cabeças de uma parte considerável das pessoas, principalmente as mais pobres.

A verdade, porém, como ela nos parece, é que não se pode falar de tudo isso em termos de grandes blocos compactados pela história. Se há algo de comum entre a atual crise dos refugiados - a maior crise humanitária desde a Segunda Grande Guerra, como insistiremos em repetir diversas vezes - e a tragédia dos massacres, diásporas e fugas do século XX, é que cada uma destas crises é a atualização da própria crise, como se ela fosse uma excepcionalidade. Atualizá-la como crise é propriamente a gestão da excepcionalidade como regra: dentro daquilo que é nomeado crise, há muitos e diferentes eventos e parte deles é governado de modo a tornar legítima, legal e normal toda iniquidade.

A crise é renovada de tempos em tempos, atualizada, de modo a recompor as relações de subordinação, de modo que o status de refugiado - o direito subjetivo de ser reconhecido refugiado e, portanto, a ter cidadania no país de acolhida -- apareça como ato de outorga e gesto benevolente, capaz de retomar a normalidade e resolver a exceção. Se então se assume que os refugiados nunca deixarão de existir e se então o sistema de refúgio é cada vez mais aprimorado, com novos protocolos de proteção, com incremento normativo e com discursos mais consistentes, isso não muda muito as coisas e, portanto, a exceção continua sendo a regra e a normalidade do governo do biopoder.

E se a “Convenção de 1951 para o Estatuto dos Refugiados” era o início do imenso sistema de proteção como o conhecemos atualmente - lembrando que antes das atrocidades nazistas e antes do massacre e fuga dos judeus e outras minorias, populações na Armênia, Rússia e outras partes do mundo já haviam instado os estados a se preocuparem com os refugiados - é preciso ver como em tal sistema sempre conviveram grandes ambiguidades e ambivalências. Talvez seja mesmo incorreto encarar o instituto de refúgio como um dispositivo único, mas, em vez disso, seja o caso de trata-lo como um conjunto ou como 
agenciamento de dispositivos heterogêneos e instáveis, dentro de um contexto dinâmico, mobilizado a partir das diferentes estratégias, e dos diversos atores que compõem o sistema.

\section{4}

\section{História e genealogia da crise}

Na literatura sobre refúgio é comum que se invoque, a partir da eleição de sua virtude essencial, suas origens num ponto remoto da história. E, neste sentido, as análises históricas e etimológicas, no esforço de confirmar sua a origem e suas virtudes, nos oferecem uma história aparentemente linear, e quase sempre em termos de evolução. No entanto, em relação ao direito de refúgio é também possível, tanto do ponto de vista etimológico quanto histórico, localizar sua vocação equívoca e ambígua. Ainda que, de nosso ponto de vista, o mais importante seja perceber o instituto de refúgio (e sua expressão em termos de direito) não como um dispositivo isolado, capaz, por si só, de produzir resultados eficientes, ainda que ambíguos, mas, em vez disso, analisar sua relação e envolvimento com os processos de governabilidade.

Uma genealogia possível do refúgio nos levaria a duas origens distintas, uma, mais etimológica do que histórica, remete ao conceito de asilo como o espaço protegido dos templos gregos. Neste sentido, o lugar de "refúgio” para se proteger dos invasores e que, na tradução latina, como "asilo", adquiriu o sentido de espaço fora da cidade, para onde poderiam escapar os perseguidos pela justiça, como os criminosos e escravos, mas também os opositores políticos ${ }^{15}$. Seja no sentido que lhes deram os gregos ou os romanos, trata-se de um espaço de exceção, que separa o mundo sagrado e o mundo profano.

A outra origem remete ao conceito de hospitalidade, que, contudo, possui uma ambiguidade essencial em termos de sua filologia: hospitalidade tem sua raiz em "hospes”, cuja origem é "hostis”, o inimigo, origem da palavra hostilidade. O estrangeiro, assim, pode ser encarado destas duas maneiras, ou pela hospitalidade ou pela hostilidade. Desta forma, considerada sua origem semântica ambivalente e

${ }^{15}$ FASSIN, Didier. “ La economia moral del asilo. Reflexiones críticas sobre la 'crisis de los refugiados’ de 2015 em Europa”. Revista de Dialectologia y Tradiciones Populares. Vol. LXX, n.2, pp.277-290, julho-dezembro 2015, p. 279. 
sua historiografia, o asilo ou refúgio contemporâneo poderia ser considerado como o sagrado direito a proteção em um espaço inviolável, a quem a hospitalidade garantiria abrigo independentemente da condição de refugiado por si, mas sempre sob o risco de hostilidade ${ }^{16}$.

O sentido moderno de refúgio, entretanto, ganhou sua forma atual a partir do século XVIII e, sobretudo, depois das duas grandes guerras. Desde a fuga dos russos do regime comunista, dos armênios escapando do massacre turco, dos judeus sobrevivendo aos nazistas e, logo depois, as grandes massas se deslocando durante e após a segunda guerra mundial. A ratificação da Convenção de 1951, precedida da criação do Alto Comissariado para os Refugiados, propiciou, em proporção internacional, estrutura legal e institucional para amparar os refugiados. Ao contrário, porém, da mítica narrativa da origem da Convenção, os governos foram muito menos generosos do que se diz e haveria uma grande história sobre as recusas e restrições a ser $\operatorname{contada}^{17}$ a começar pela própria definição de refugiado.

A Convenção de 1951 limitava seu âmbito de atuação aos europeus vítimas da segunda guerra mundial. De acordo com a definição estabelecida pela Convenção, o refugiado é a pessoa que,

\begin{abstract}
"consequência dos acontecimentos ocorridos antes de $1^{\circ}$ de janeiro de 1951 e temendo ser perseguida por motivos de raça, religião, nacionalidade, grupo social ou opiniões políticas, se encontra fora do país de sua nacionalidade e que não pode ou, em virtude desse temor, não quer valer-se da proteção desse país, ou que, se não tem nacionalidade e se encontra fora do país no qual tinha sua residência habitual em consequência de tais acontecimentos, não pode ou, devido ao referido temor, não quer voltar a ele”.
\end{abstract}

Somente com o Protocolo de Nova Iorque, de 1967, a restrição geográfica e temporal foi resolvida em favor da universalização da proteção. Mesmo assim, o instituto de refúgio manteve desigualdades no tratamento aos refugiados, agora pela divisão entre os refugiados do sul global e os solicitantes de refúgio no norte. A suposta generosidade dos países do norte nas décadas posteriores à Convenção de 1951 era motivada sobretudo pela expansão econômica durante a reconstrução

${ }^{16}$ FASSIN, Didier. “ La economia moral del asilo. Reflexiones críticas sobre la 'crisis de los refugiados’ de 2015 em Europa”. Revista de Dialectologia y Tradiciones Populares. Vol. LXX, n.2, pp.277-290, julho-dezembro 2015, p. 280.

${ }^{17}$ Ibidem, p. 280. 
da Europa no período pós-guerra, o que significava, de modo geral, necessidade de ampliação demográfica e de força de trabalho. Ao mesmo tempo, a Guerra Fria dava condições para que os países ocidentais recebessem como refugiados as pessoas que fugiam dos regimes comunistas. No contexto da Guerra Fria, a generosidade dos países de acolhida era também uma estratégia política de tensionamento.

Interessa analisar, acima de tudo, a recepção positiva como eram percebidos positivamente os refugiados durante certo período, ainda que houvesse sempre uma reserva negativa em relação a um grupo ou por parte de alguns setores das sociedades de acolhida. No período subsequente à Segunda Guerra, os sentimentos morais em relação aos refugiados eram de lástima e solidariedade, algo próximo ao que aconteceu com as vítimas do comunismo, nos anos seguintes, recebidas com empatia. Ainda que esta representação positiva não fosse isenta -- basta lembrar que, até 1967, apenas europeus atingidos pela guerra eram considerados refugiados - a distinção entre migrantes e refugiados, que se tornaria um grande problema nas décadas seguintes - e se tornaria um dos pontos principais da atual crise dos refugiados - nem sequer era uma questão. Muitos dos que estavam em condições de serem reconhecidos como refugiados, aliás, conseguiram documentos através de contratos de trabalho, algo que se inverteria a partir das décadas de 1970 em diante.

Na década de 1970, apesar do fortalecimento das fronteiras, no contexto da Guerra Fria em declínio, a maioria dos países europeus demonstrava ampla simpatia pelos refugiados, especialmente por aqueles que fugiam dos regimes comunistas e das ditaduras latino-americanas, como forma de expressar seu apreço pelos direitos humanos como uma política universal. Na França, os solicitantes de refúgio, especialmente os que fugiam da ditadura no Chile e os vietnamitas que saíram de Saigon em 1975, tiveram solidariedade ampla dos políticos, de diferentes posições. E mesmo diante do fato de que as solicitações de refúgio multiplicaram dez vezes naquela década ${ }^{18}$. Mesmo quando a migração passou a ser encarada como risco à segurança e aos empregos dos nacionais, a imagem moral dos refugiados seguia positiva ${ }^{19}$.

\footnotetext{
${ }^{18}$ Fassin (Ibidem), p. 284.

${ }^{19}$ Ibidem.
} 
A ascensão da Europa de Schengen nos anos 1980, em contexto de fortalecimento das fronteiras e de crescimento da xenofobia, as políticas de refúgio e as políticas de controle migratório passam a se relacionar de modo mais indiscriminado. Na retórica dos políticos, no contexto de avanço da direita no comando político da Europa e do norte global, os solicitantes de refúgio são associados a migrantes indocumentados e cada vez mais são vistos com desconfiança. O sistema de análise e julgamento dos pedidos de refúgio se torna ainda mais rigoroso, deixando evidente que os solicitantes eram percebidos como mentirosos e suspeitos. Na França, a proporção de solicitantes reconhecidos dificilmente excedia $10 \%$ e mesmo os haitianos e os congoleses - afetados por uma guerra que naquela década contabilizava três milhões de mortos - não desfrutaram da simpatia que antes ${ }^{20}$.

A partir de então, atendendo às novas redefinições das fronteiras do refúgio, o sistema de análise e decisão toma a forma como hoje o conhecemos. A contraposição entre os grandes fluxos de refugiados no sul, de um lado, e o fluxo "misto" de refugiados "urbanos" no norte marcam as novas fronteiras do refúgio e a forma de sua gestão. Sul e norte, no entanto, não são exatamente localizações geográficas, mas, antes, indicações para novas demarcações geopolíticas e biopolíticas. Na América do Sul, por exemplo, ambos os sistemas convivem lado a lado: no Equador, fluxos massivos de refugiados colombianos acomodados de modo improvisado. E, ao mesmo tempo, um sistema de análise individualizada, com uma fase prévia de admissibilidade (para selecionar quem pode ser selecionado). No Brasil, um sistema de análise individualizada é cada vez mais aprimorado, de modo a ser capaz de distinguir, no "fluxo misto", os refugiados dos migrantes. E ainda que a taxa de elegibilidade seja comparativamente alta $^{21} \mathrm{e}$ que o número de solicitantes e refugiados seja insignificante, principalmente em comparação com o fluxo de colombianos no Equador, os dispositivos de distinção tendem a ganhar força.

\footnotetext{
${ }^{20}$ Fassin (Ibidem), p. 285.

${ }^{21}$ Sobre os índices de deferimento e indeferimento, ver os dados compartilhados pelo Conare. Os dados estão disponíveis no site do ACNUR (http://www.acnur.org/t3/portugues/recursos/estatisticas/dados-sobre-refugio-no-brasil/) (Último acesso em 15/06/2016).
} 
Ainda no Brasil, aliás, seria interessante analisar a questão dos haitianos, talvez a mais emblemática entre as questões envolvendo refugiados, mesmo que eles não sejam considerados refugiados e justamente por isso. Neste mesmo país, onde o sistema de elegibilidade individualizado é a regra, os haitianos são recebidos como migrantes econômicos - depois de um breve período em que eram percebidos como migrantes ambientais - e acomodados nos abrigos improvisados. O sistema do sul convivendo com o sistema do norte, operando critérios raciais. A solução "humanitária” para os haitianos -- que merece ser celebrada por regularizar cerca de 80 mil pessoas no Brasil - somente se tornou possível porque a representação dos haitianos foi construída com base na imagem de vítimas de uma catástrofe.

\section{5}

\section{Os refugiados no sul do mundo}

Na parte sul do mundo, as crises de refugiados exigiram esforços por uma solução adequada e tanto na África quanto na América Latina, houve iniciativas para uma definição de refúgio que fosse mais ampla e generosa do que o sistema individualizado estabelecido pela Convenção de 1951, na Europa. Os violentos conflitos na África no período subsequente às lutas por independência, durante os anos 1960, e as perseguições na América Latina, sobretudo no decorrer dos anos 1970, demandaram dos estados uma resposta para os refugiados e deslocados, uma vez que o sistema da Convenção ainda era restritivo para as situações vividas naquelas regiões. O vento da democracia que soprava pela África pós-colonial logo foi engolido pelas lutas sangrentas por poder, com participação direta dos antigos colonizadores. E a América Latina mergulhava no período de ditaduras e porões de tortura, como sintoma direto da guerra de polarização conhecida por Guerra Fria.

Os estados africanos estabeleceram, em 1969, a Convenção da Organização de Unidade Africana, para tratar de aspectos específicos dos problemas dos refugiados na África. Dentre outras determinações, a Convenção criou uma definição ampliada de refugiado, reconhecendo que a proteção pode ser declarada a: 
“qualquer pessoa que, devido a uma agressão, ocupação externa, dominação estrangeira ou a acontecimentos que perturbem gravemente a ordem pública numa parte ou na totalidade do seu país de origem ou do país de que tem nacionalidade, seja obrigada a deixar o lugar da residência habitual para procurar refúgio noutro lugar fora do seu país de origem ou de nacionalidade”.

Na América Latina, a iniciativa por uma definição de refúgio própria para as vítimas da violência na região surgiu dos acadêmicos, que elaboraram, em 1984, a Declaração de Cartagena ${ }^{22}$. Embora houvesse nos países da região, uma longa e forte tradição de asilo a pessoas que enfrentavam perseguições por razões políticas, este sistema de proteção regional, enfrentou uma grande crise na década de 1960. A fuga dos cubanos e os exilados da Bolívia, Haiti, Honduras, Nicarágua e Paraguai mostraram a incapacidade dos estados quanto sua capacidade em acolhe refugiados. E na tentativa de dar solução adequada para a crescente crise dos refugiados, a Comissão Interamericana de Direitos Humanos elaborou um rascunho para a Convenção Interamericana de Refúgio, que acabou não sendo acatada por nenhum dos membros da Organização dos Estados Americanos (“OEA”). Em realidade, grande parte dos estados membros era reticente quanto à assinatura da Convenção de 1951, muito provavelmente para evitar alguma forma de controle internacional.

A situação dos refugiados na América Central se deteriorou drasticamente nas décadas seguintes, com milhares de mortos e desparecidos, além das vítimas de tortura e detenção arbitrária. Nos países do cone sul, crescia o número de desaparecidos e ao final da década de 1970, havia um número considerável de pessoas necessitando de proteção. Diferentemente do que era comum antes, em vez de iminentes figuras políticas, eram pessoas comuns que temiam perseguição por parte de seus governos.

Frente à inércia dos Estados e da OEA, um grupo de especialistas e acadêmicos decidiu elaborar um documento que pudesse tratar da crise dos

22 De acordo com as recomendações estabelecidas na Declaração de Cartagena, de 1984, a definição ou o conceito de refugiado, além de conter os elementos da Convenção de 1951 e do Protocolo de 1967, consideraria também como refugiados as pessoas que tenham fugido dos seus países porque a "sua vida, segurança ou liberdade tenham sido ameaçadas pela violência generalizada, a agressão estrangeira, os conflitos internos, a violação maciça dos direitos humanos ou outras circunstâncias que tenham perturbado gravemente a ordem pública”. A Lei brasileira (Lei 9.474/97, artigo 1, inciso III) assimilou em parte esta definição, definido refugiado como a pessoa que, “devido a grave e generalizada violação de direitos humanos, é obrigado a deixar seu país de nacionalidade para buscar refúgio em outro país”. 
perseguidos. Influenciados pelo texto da Convenção da Organização de Unidade Africana $^{23}$ (1974), a Declaração de Cartagena convocou os países a usar uma definição ampliada de refugiado, incluindo, além daqueles protegidos nos termos da Convenção de 1951 e do Protocolo de 1967, as pessoas que tenham fugido de seus países porque sua vida, segurança ou liberdade tenham sido ameaçadas pela violência generalizada, agressão estrangeira, conflitos internos, violação maciça dos direitos humanos ou outras circunstâncias que tenham perturbado gravemente a ordem pública.

A definição ampliada aos poucos foi incorporada pelos estados da região em sua legislação: sete dos 17 países - incluindo Argentina, Bolívia, Chile, El Salvador, Guatemala, México e Nicarágua - usam a definição contida na Declaração e outros seis países usam a definição com pequenas diferenciações na redação. Apenas três países - Costa Rica, Panamá e Venezuela - não incorporaram a definição em seus sistemas nacionais. Uma recente alteração na legislação de Equador - o primeiro país da América Latina a introduzir a definição em sua lei doméstica, em 1987 - determinou um grave retrocesso neste tema.

O Brasil, junto com Colômbia, Paraguai e Peru, limitaram o alcance, definindo que serão refugiados aqueles “forçados” ou "obrigados” a deixar seus países de origem como resultado de uma situação objetiva, incluindo assim o elemento de compulsão ou obrigação como causa para fuga. A definição de refugiado da Declaração de Cartagena, porém, requer tão somente que haja uma ameaça genérica à vida, à liberdade e à segurança gerada por uma das cinco situações objetivas determinadas na Declaração. A legislação interna de alguns países - no Brasil, Uruguai, Honduras e Peru - introduziu algumas modificações às cinco situações objetivas presentes na definição regional. No Peru, substituiu-se a expressão “violência generalizada” por “dominação ou ocupação estrangeira”. No caso do Uruguai, por exemplo, foi incluída a situação de “terrorismo”. Quanto aos hondurenhos, à “violência generalizada” acrescentou-se que esta precisaria ser “grave e contínua”. Em Honduras, a propósito, a legislação reconhece também pessoas que buscam refúgio por razões de violência sexual ou outras formas de violência baseada no gênero da pessoa. E inclui elementos que definem os termos

\footnotetext{
${ }^{23}$ Convenção da Organização de Unidade Africana, adotada pela Convenção dos Chefes de Estado
} e do Governo, realizada de 6 a 9 de setembro de 1969, entrando em vigor em 20 de junho de 1974. 
“agressão externa e conflitos armados internos”, com o fim de evitar equívocos ou distorções.

A definição utilizada pelo Brasil - comparativamente à definição usada nos demais países -- foi a que mais se distanciou da definição original proposta pela Declaração. Além da definição clássica, de acordo com a Convenção de 1951 e o Protocolo de 1967, a lei brasileira assimilou a proposta da Declaração, mas em outros termos, prevendo proteção “àqueles que devido a uma grave e generalizada violação de direitos humanos foram forçados a deixar seu país de origem para buscar refúgio em outra nação”. O Equador foi o único país da região que utilizou a definição de refugiado nos termos da Declaração de Cartagena e, mesmo assim, sua prática foi interrompida por meio de alteração legal motivada por decreto presidencial em maio de 2012. O procedimento anteriormente adotado pelo governo equatoriano se baseava em referências geográficas juntamente com dados do país de origem sobre possíveis ameaças objetivas a violações de direitos humanos, presença de grupos armados, combatentes ou outras fontes de violência.

De qualquer forma, a definição ampliada proposta pela Declaração teve pouco impacto nas práticas das instituições estatais. Em alguns casos, porque os estados utilizam uma definição mais restritiva em suas leis ou porque os estados limitam o seu uso. Tais restrições e limitações não são acidentais e estão ligadas, em grande parte, à conservação de um modelo individualizado de refúgio. Desta forma, como as decisões são sempre referidas a uma experiência individual, os estados não se comprometem com uma avaliação sobre o contexto geral do país e, esta forma, manter o controle sobre os fluxos (de pessoas, direitos e subjetividades).

A fronteira entre o sul e norte, portanto, não é natural, geográfica nem sequer fixa. Ela se atualiza inclusive dentro do território de um mesmo país e poderíamos dizer que a fronteira - aquela que determina dois diferentes tipos de regime de reconhecimento de refugiados - é também a fronteira vinculada à diferenciação e desigualdade racial e social: fronteiras biopolíticas que se afirmam com base na distinção racial, para reforçar o abismo entre brancos e não-brancos e entre ricos e pobres. Ou, ainda, criando novas classes e raças "inferiores”, pelo acréscimo do status de “migrantes” ou “refugiadas” à sua condição já minoritária, acentuando as percepções de ilegalidade, risco ou ameaça. Marcando na pele e no rosto cansado o status jurídico. Na economia moral do mundo atual, o refugiado é 
representando como o "ilegal” que consegui um acesso excepcional pela fronteira e, desta forma, ele é a origem de uma nova raça menor e seu corpo é ele mesmo tornado o lugar da fronteira.

\section{6}

\section{Gestão global dos fluxos}

A definição das fronteiras do refúgio obedece à mesma lógica da soberania pós-moderna: a gestão do sistema de refúgio, a despeito das particularidades regionais, das particularidades dos fluxos, das condições históricas, demográficas, geográficas e políticas de cada história, é arranjada de modo global e descentralizada. Funciona como os dispositivos de poder, isto é, rizomáticos, fluídos e com verticalidades eventuais, ocupando o conjunto das relações das sociedades de um modo global. Mesmo situado na parte que se convém chamar de sul, o Brasil, por exemplo, como parte integrante da gestão global do sistema de refúgio, participa das definições da fronteira do norte. Assim como a Turquia, por meio dos acordos com a Comunidade Europeia, adiciona-se, de modo concreto e material (e militar) às fronteiras da Europa. O norte e o sul convivem no mesmo território e em diferentes corpos da população.

Mesmo distante dos grandes fluxos de migrantes ou refugiados, no Brasil, a exemplo do que ocorre nos países do norte, os solicitantes são avaliados e valorados individualmente, através de processos inquisitivos, nos quais o exame sobre a veracidade tem mais importância do que as informações objetivas sobre o país. Mais do que um exame sobre o contexto e a natureza do fluxo, sobre as condições que determinam a fuga ou sobre o temor do solicitante em ficar em seu país, trata-se de uma investigação sobre a verdade do solicitante. Sobre sua credibilidade e sua sinceridade. E sempre como pressuposto que os solicitantes estão tentando enganar os julgadores. E tudo isso a despeito de um grande esforço regional - na América Latina - no sentido de desenvolver uma nova definição de refugiado com a Declaração de Cartagena de 1984.

Esta análise da verdade, aliás, não se limita ao pedido inicial de refúgio, mas se estende a todos os seus atos, inclusive depois que a pessoa é reconhecida como refugiada. Seu compromisso com a sinceridade é eterno. Os refugiados, no Brasil, 
quando solicitam a autorização obrigatória para viagens temporárias fora do país - sob pena de perderem o status - são igualmente interrogados sobre sua verdade: sobre o motivo de sua viagem, sobre o tempo da viagem, e outras informações que não guardam qualquer relação com sua proteção e que, a rigor, diriam respeito à sua absoluta privacidade: quem vai visitar, por qual razão e onde moram. E se em qualquer momento dentro de sua relação com a burocracia estatal o refugiado comete um deslize ou se é mal interpretado, a inverdade poderá ser usada como motivo para retirar-lhe seu status jurídico e, logo, sua condição regular no país. E mesmo seu silêncio ou sua recusa em responder serão motivos para negar-lhe o direito a viajar.

A honestidade e a credibilidade do refugiado são a condição para que a fronteira não feche sobre si. Pessoas que deixaram países em guerra ou em evidente crise humanitária terão que provar sua sinceridade, contornar a suspeita dos julgadores e conquistar sua confiança. Mais do que tudo, terão que convencêlos de que são vítimas e que a violência é algo que lhes diz atinge pessoalmente. Sejam elas camponesas vítimas dos paramilitares na Colômbia, mulheres vítimas de estupros no Congo, cristãos perseguidos pelo Boko Haram ${ }^{24}$ na Nigéria, todas devem confessar sua condição de vítimas inocentes. A situação geopolítica interessa apenas enquanto está relacionado a uma vítima. O humanitarismo do sistema de refúgio resgata o humano desde que ele se mostre digno de condescendência e piedade e tão somente se passa pelo crivo da confiabilidade e honestidade. Encontra o humano apenas no que crê ser o resto sua vida e de resistência.

Não há nada na Convenção de 1951, e nem mesmo nos documentos adicionais que ampliaram a definição de refugiado, acerca da análise de credibilidade. O único ponto em que alguma análise mais subjetiva é permitida

24 Grupo fundado em 2002, inicialmente focado em contestar o Ocidente e as formas de influências culturais e educacionais ocidentais. Lançou operações militares a partir de 2009, para criar um estado islâmico e acabou por ser designado como grupo terrorista, em 2013, pelo governo dos Estados Unidos da América. Ficou famoso por causa do sequestro de centenas de mulheres e garotas, em 2014. O nome original do grupo é “Jama'atu Ahlis Sunna Lidda'awati wal-Jihad”. Traduzindo do inglês "People Committed to the Propagation of the Prophet's Teachings and Jihad", seria algo como "Povo comprometido com a propagação dos ensinamentos do profeta e com a Jihad”. Algumas informações podem ser obtidas em "Testemunhas relatam terror do Boko Haram um ano após sequestro coletivo de estudantes” BBC Brasil. Stephanie Hegarty. 14/04/2015. (Disponível em http://www.bbc.com/portuguese/noticias/2015/04/150413_vida_boko_haram_pai) (Último acesso em 12/06/2016). 
pela Convenção, assim como acontece na lei brasileira (Lei 9.474/97), refere-se ao “fundado temor de perseguição", que não se confunde, no entanto, com a credibilidade do solicitante. Em geral, as regras sobre a análise de credibilidade são elaboradas e compartilhadas pelo ACNUR, através de orientações, diretrizes e recomendações ${ }^{25}$. Estas orientações globais ${ }^{26}$ tratam do modo como os julgadores devem tratar as informações e provas trazidas pelos solicitantes, mas também sobre o modo como se deve avaliar a sinceridade das informações e do perfil do solicitante ${ }^{27}$.

Enquanto o fundado temor se refere à gravidade, potencialidade, iminência ou possibilidade de risco percebida pelo indivíduo - o que, por si, é uma distorção da realidade, se levamos em conta que a violência não é uma experiência individual, mesmo no caso das perseguições - a credibilidade diz respeito à verdade do que diz o solicitante. É sobre a verdade de si mesmo que se trata, isto é, se ele é de fato um refugiado ou não. Não por outra razão que em alguns países, como Reino Unido, o indeferimento de um pedido é atribuído a uma falha do próprio solicitante (“failed asylum seeker”).

\section{7}

\section{Verdade, poder e a palavra dos refugiados}

A palavra dos refugiados é tomada apenas como e enquanto elemento de provas suficiente para demonstrar que se trata de uma pessoa que possui o

25 O mais importante destes documentos é o "Manual de procedimentos e critérios para a determinação da condição de refugiado, de acordo com a Convenção de 1951 e o Protocolo de 1967 Relativos ao Estatuto dos Refugiados”, Genebra, ACNUR, 2011. (Disponível em http://www.acnur.org/t3/fileadmin/Documentos/portugues/Publicacoes/2013/Manual_de_procedi mentos_e_criterios_para_a_determinacao_da_condicao_de_refugiado.pdf?view=1) (Último acesso em 12/06/2016).

${ }^{26}$ A versão em inglês, utilizado como referência em vários países do norte, está disponível em http://www.unhcr.org/publications/legal/3d58e13b4/handbook-procedures-criteria-determiningrefugee-status-under-1951-convention.html (Último acesso em 12/06/2016).

${ }^{27}$ Diante de um solicitante que teme ser perseguido em virtude de sua conversão religiosa, o Manual recomenda: "quando os indivíduos se convertem após deixarem o seu país de origem (...) surgem preocupações específicas quanto à credibilidade e será necessário realizar um exame profundo e rigoroso das circunstâncias e genuidade da conversão. Dentre as questões que o tomador de decisão deverá avaliar estão a natureza e a conexão entre a convicção religiosa adotada no país de origem e aquela que o solicitante adota no presente; (...) sua experiência com essa nova religião; (...) e a existência de evidências que confirmem o seu envolvimento e filiação à nova religião. "Manual de procedimentos e critérios para a determinação da condição de refugiado, de acordo com a Convenção de 1951 e o Protocolo de 1967 Relativos ao Estatuto dos Refugiados”, Genebra, ACNUR, 2011.p.137. 
“fundado temor de perseguição”, conforme a figura clássica do refugiado. É apenas como uma peça de um processo, dentre outras peças, que sua palavra tem valor, e, ainda que seja a prova mais relevante, ela está subordinada a um jogo previamente determinado, à qual sua palavra deve corresponder. Discurso subordinado à verificação da verdade, perscrutada pelos julgadores e especialistas, que de antemão são capazes de dizer o que é e o que não é um refugiado. A distinção quer apagar inclusive o fato de que, em grande parte do mundo onde funciona o sistema de elegibilidade, todo refugiado deve viver como migrante, ou seja, buscar sua subsistência por sua própria conta.

A verdade a ser "revelada” está determinada desde o começo, como pressuposto. O refugiado é aquele que foge involuntariamente de uma perseguição concreta, provável ou iminente. Ele não tem proteção em seu país e só lhe restou fugir. E, afinal, é uma vítima incapaz de decidir e escolher, restando-lhe apenas entregar sua sobrevivência a outro Estado que garanta segurança. Se em vez de relatar a inevitabilidade de sua fuga, ele afirma a voluntariedade, haverá riscos para seu pedido. Se em vez de insistir na sua própria fragilidade, na precariedade da vida, na sobrevivência como critério para o direito ao refúgio, ele afirma o desejo por uma vida melhor, mais justa, assume os riscos de se denunciar como migrante. Se algo escapa ao roteiro, se ele não atende às expectativas, se não chora no momento certo, se ri no momento errado, se gagueja, tudo isso pode ser um risco. Então a verdade é rara ou inexistente.

\section{8}

\section{O processo de refúgio no Brasil}

No Brasil, a avaliação e determinação dos pedidos de refúgio dependem de um processo que segue as regras do típico processo administrativo, mas com algumas características peculiares, em consideração à situação excepcional dos refugiados e solicitantes de refúgio. Como a maior parte das pessoas que fogem não é capaz de trazer documentos que possam provar o fundado temor de perseguição ou como foi atingido pelo contexto de grave violência, o seu depoimento se torna o principal ou o único meio de prova. Por esta razão, a entrevista pessoal com os solicitantes de refúgio se torna, na maior parte dos casos, o momento mais importante do processo. 
E, nestes termos, a credibilidade do depoimento é um dos critérios capaz de decidir se uma pessoa é declarada refugiada ou não. A maior parte das regras para análise e avaliação das provas e da narrativa dos solicitantes, contudo, não consta de lei ou de resoluções, mas estão elencadas em diretrizes e orientações feitas pelo $\mathrm{ACNUR}^{28}$. São as mesmas recomendações seguidas por quase todos os países do norte que recebem solicitantes de refúgio, mas também nos países do sul onde os refugiados chegam dentro do chamado "fluxo misto", exigindo então a distinção entre solicitantes e refugiados. São padrões de análise e julgamento compartilhados por quase todos estes países, a partir de diretrizes gerais do ACNUR, mas também incluindo experiências e práticas concretas dos diferentes atores estatais e não-estatais, através de uma imensa e instável rede de comunicação e intercâmbio.

A finalidade da entrevista de elegibilidade, de acordo com as diretrizes do ACNUR (2013, p. 17), é “identificar os fatos e fazer uma imagem dos eventos que seja a mais completa e objetiva possível”. Esse esforço de objetividade remete à ponderação da credibilidade da narrativa feita pelo solicitante, que é avaliada durante a entrevista e em momento posterior. O reconhecimento do status de refugiado, de acordo com as regras do sistema, deve ser amparado numa história verdadeira, implicando que o instituto do refúgio depende de mecanismos de busca e produção de verdade sobre a trajetória do solicitante.

O manual do ACNUR de metodologia e técnicas para entrevistar solicitantes de refúgio deixa evidente a importância da credibilidade do relato e da busca pela verdade dos fatos. Um dos tópicos presentes nesse manual refere-se à “obrigação de ser verdadeiro” (ACNUR, 2013, p. 21). Os solicitantes são convocados a narrar coerentemente a relação entre os fatos que motivaram a sua fuga por meio de um testemunho "honesto e confiável”. Para tanto, cabe ao entrevistador identificar eventuais discrepâncias na narrativa do solicitante, de modo a colocar em cheque sua credibilidade. Esse procedimento é bem representativo da necessidade de verdade discutida por Foucault (2010b, p. 20-

${ }^{28}$ O mais importante destes documentos é o "Manual de procedimentos e critérios para a determinação da condição de refugiado, de acordo com a Convenção de 1951 e o Protocolo de 1967 Relativos ao Estatuto dos Refugiados”, Genebra, ACNUR, 2011. (Disponível em http://www.acnur.org/t3/fileadmin/Documentos/portugues/Publicacoes/2013/Manual_de_procedi mentos_e_criterios_para_a_determinacao_da_condicao_de_refugiado.pdf?view=1) (Último acesso em 12/06/2016). 
22). Nesse sentido, avaliar a credibilidade de uma solicitação de refúgio deve ser uma das principais tarefas do entrevistador, o que inclui, dentre outras coisas, conferir declarações dúbias ou enganosas, considerar a fluidez do testemunho e ponderar o comportamento do solicitante. A avaliação da credibilidade do solicitante relaciona-se com a veracidade de sua declaração (ACNUR, 2013, p. $53)$.

O mesmo manual do ACNUR determina que as solicitações devem estar bem documentadas e devem manter consistência interna (coerência da declaração) e externa (equivalência com os fatos objetivos conhecidos) para facilitar as conclusões a que chegam os entrevistadores. Por outro lado, o manual (2013, p. 52) reconhece que "não existem regras que podem ser aplicadas cegamente”, vez que os distintos ordenamentos jurídicos e procedimentos nacionais de refúgio estão relacionados a práticas sociais de seus contextos culturais, dificultando o alcance de critérios, a priori, universalmente aplicáveis.

Se no Brasil vemos os mesmos problemas que acontecem no Reino Unido, então talvez seja preciso insistir que o instituto ou sistema de refúgio é a gestão, em nível local e global, dos fluxos de pessoas, de seus direitos e subjetividades. Um esforço de classificar, nomear e homologar os fluxos e as fugas, de acordo com uma determinada economia de poder e de moral. A presença do ACNUR em quase todos os países de acolhida a solicitantes de refúgio não pode ser a única justificativa para explicar que os problemas sejam comuns. E a despeito das diferenças em cada estado, conforme as diferentes forças e atores presentes, o sistema tende a produzir e reproduzir a criação de fronteiras segundo uma governança da iniquidade.

$\mathrm{E}$, mais que isso, uma ontologia da iniquidade, produzindo subjetividades fundadas na culpa por fugir. E que no Brasil o número de refugiados e solicitantes de refúgio seja irrelevante ${ }^{29}$, sem nenhum impacto social, econômico ou mesmo

\footnotetext{
${ }^{29}$ De acordo com dados oficiais do Conare, o Brasil tem 8.863 refugiados, dos quais, 2.298 são de nacionalidade síria. O número de solicitações aguardando solução, porém, aumentou $2.868 \%$ no período entre 2010 a 2015. São 28.670 pessoas, de 79 diferentes nacionalidades. Em 2010, eram 966 pessoas, em 2014, eram 28.385. A grande maioria (80,8\%) é composta de homens adultos (18 a 59 anos). As principais nacionalidades de solicitantes são: haitianos, senegaleses, sírios, bengaleses e nigerianos. Enquanto que as principais nacionalidades de refugiados reconhecidos são: sírios, angolanos, colombianos, congoleses e libaneses. Em 2013, quando os números já eram anunciados com certo alarme, foram apresentadas no país 5.256 solicitações, o que já significava um aumento de quase dez vezes em relação a ano anterior. A previsão era de que ao final de 2014, houvesse de 10 a 12 mil pedidos. A maior parte dos pedidos feitos em 2013, de acordo com os
} 
político, o que interessa do ponto de vista da análise da governança do biopoder, é o modo como se constituem, incrementam e lubrificam os dispositivos de gestão dos fluxos de pessoas em fuga, em dimensão global. Esta gestão dos fluxos depende de uma economia moral baseada na verdade confessada pelos refugiados e na sua inocência como valor.

\section{9}

\section{Distinção entre refugiado e migrante: a vítima inocente}

A definição de refugiado depende da possibilidade de distingui-la da definição de migrante e tal distinção tem como critério a liberdade e a vontade: de um lado, a coerção da fuga, no caso dos refugiados e, portanto, a inexistência da vontade e da voluntariedade. De outro, a espontaneidade e a voluntariedade, no caso dos migrantes, que viajam em busca de uma vida melhor. E se o estado opera sobre esta lógica, é preciso ver que a retórica das organizações humanitárias e das campanhas de sensibilização estão baseadas nesta mesma distinção: somente a imagem da vitimização e da inocência permitem a existência do refugiado. É preciso, para atravessar as fronteiras (os muros e a burocracia), não ser culpado pela própria fuga. Esta distinção -- que não é absoluta, nem total e não opera sem enfrentar resistências - pretende apagar as nuances entre os sujeitos, entre os motivos das fugas, e também quer neutralizar qualquer pensamento ou crítica sobre os conflitos e a violência, fragmentando as narrativas para que se possam selecionar apenas as confissões de dor e impotência.

Há uma retórica comum utilizada pelos que defendem a análise de credibilidade como critério relevante: ela é necessária para impedir o uso indevido do direito de refúgio pelos migrantes. Este consenso em torno da rarefação do refúgio é compartilhado globalmente, com aquiescência de todos os atores. De modo geral, os sujeitos engajados na defesa da credibilidade - no Brasil, desde os servidores públicos responsáveis pelas entrevistas com os solicitantes, os que elaboram os pareceres, os julgadores presentes na plenária, mas também os representantes das agências humanitárias internacionais e das organizações da

países de origem: Bangladesh, com 1.837 pedidos, Senegal, com 961 pedidos, Líbano, com 320 pedidos. Os dados estão disponíveis no site do ACNUR (http://www.acnur.org/t3/portugues/recursos/estatisticas/dados-sobre-refugio-no-brasil/) (Último acesso em 15/06/2016). 
sociedade civil $^{30}$-- parecem convencidos de que é preciso zelar com ardor para que o refúgio não seja usado indevidamente.

A “preservação do instituto" significa, em última instância, mantê-lo como excepcionalidade. Eis a crise: o direito como escassez e excepcionalidade. É com base nesta lógica que agem os organismos dos estados e também as agências humanitárias; e é defendida até mesmo por um grande número de especialistas e acadêmicos. O fundamento desta retórica situa-se numa ideia simples: a falta de rigor na eleição (e na distinção) dos refugiados pode fragilizar a credibilidade do instituto e romper o supostamente frágil consenso (entre os estados), colocando em risco a vida dos próprios refugiados.

O argumento expressa uma óbvia chantagem: o consenso global que sustenta a proteção aos refugiados está baseado naquele regime de escassez, em que é preciso constantemente produzir a distinção arbitrária entre os que merecem e os que não merecem o status de refugiado. A arbitrariedade, neste caso, não incidental. Ela é a peça fundamental. No fundo, se trata de conceber a cidadania e o pertencimento ao estado como uma escassez. E ainda mais ao fundo, se trata de conceber a vida mesma como escassez. A cidadania somente é possível quando a vida está no limite de sua rarefação. O consenso que permite a proteção é o consenso em torno de um conceito de vida. É, ao final, disso que se trata: a definição do que é a vida.

Separar, classificar e distinguir os migrantes dos refugiados é um modo de garantir proteção aos que foram obrigados a fugir, mas a distinção também sanciona os refugiados "verdadeiros”, as perseguições e guerras realmente graves e, enfim, as vítimas que merecem proteção. Nesta operação, os refugiados “verdadeiros”, os refugiados “falsos”, os refugiados que "fracassaram” (“failed asylum seeker”), os migrantes por “razões humanitárias”, os migrantes

${ }^{30}$ Lei 9.474/97 determinou a criação do Comitê Nacional para os Refugiados (Conare) órgão ao qual cabe, de acordo com o art. 12, dentre outras atribuições, criar políticas públicas para os refugiados e solicitantes de refúgio analisar e decidir os pedidos de refúgio em primeira instância (inciso I). O Conare, de acordo com o art. 14, é composto por representantes do Ministério da Justiça (a quem cabe sua presidência), do Ministério das Relações Exteriores, do Ministério do Trabalho, do Ministério do Trabalho, do Ministério da Saúde, do Ministério da Educação e do Desporto, do Departamento de Polícia Federal e de um representante de organização nãogovernamental dedicada à assistência e proteção de refugiados. Todos estes atores têm direito a votar nas sessões. Além destes, o ACNUR (Alto Comissariado das Nações Unidas) ( $\left(1^{\circ}\right)$, a Defensoria Pública da União e o Instituto Migrações e Direitos Humanos (IMDH) são considerados membros convidados, com direito a voz, mas sem direito a voto. 
“ambientais” e os migrantes “econômicos” são classificados em hierarquias por ordem de mérito, e a todos eles resta algum tipo de subjugação.

Aos que merecem o refúgio e aos que não merecem são distribuídas diferentes cidadanias, ligadas não apenas a uma determinação jurídica, mas de acordo com certa economia moral: quem é vítima e quem não é e dentre eles, quem é mais vítima e quem é mais inocente. A crise, deste ponto de vista, não pode ser narrada como mera insuficiência das instituições ou do direito frente a problemas concretos. A crise é a governança com características de excepcionalidade. 


\section{2}

\section{Direito de refúgio e a vida como fundamento}

"Foi preciso que as vítimas pensassem e vivessem de outro modo para dar matéria àqueles que choram em seu nome, e que pensam em seu nome, e que dão lições em seu nome. Foi a sua força de vida que os impeliu, não a sua amargura (...)”

Gilles Deleuze \& Claire Parnet ${ }^{31}$.

Em sua institucionalidade oficial, o estatuto político do refugiado é o estatuto fundado na quase-vida, a vida diminuída em sua potência de resistir. O seu estatuto como cidadão e sua inscrição na existência política da cidade se dá, portanto, por meio do reconhecimento de seu sofrimento passivo e sua dor, ao mesmo tempo em que sua tragédia possa atestar sua inocência. Somente após ser salvo pelo soberano e somente depois de purificar-se pela confissão, o refugiado pode encontrar sua redenção. Nunca antes de confessar incessantemente sua dor e sua inocência.

Diante da inigualável tragédia que se tornou a crise dos refugiados, parece imprudente colocar a razão humanitária sob crítica. Especialmente porque milhões de pessoas estão hoje protegidas graças às ações das organizações humanitárias e da retórica dos direitos humanos. No entanto, considerar a vida apenas em seu momento de limiar biológico, como mera sobrevivência, é a tentativa de neutralizar a vida em sua potência de resistir e de criar.

A vida se tornou o lugar onde incide o poder e onde estão as resistências. Mas é a vida diminuída, como mera sobrevivência, que se torna o fundamento do governo do biopoder. Em complemento às "razões de estado”, o governo mantém a sua face benevolente, na forma das "razões humanitárias". E na medida em que a razão humanitária passa a integrar a governabilidade e a gestão das vidas e das populações, a distinção, quase sempre arbitrária, entre os refugiados e migrantes de um lado, as vítimas inocentes e passivas, e, de outro, os que ousam buscar uma

${ }^{31}$ DELEUZE, Gilles e PARNET, Claire. Diálogos. Lisboa: Relógio D`água, 2004p. 174 
vida "melhor" - assinala em suas existências uma qualidade moral que deve ser confessada pelos próprios sujeitos.

A cidadania, de acordo com o governo "humanitário", pode ser concedida apenas àqueles que se apresentam e se testemunham como vítimas. Apenas o sofrimento pode libertá-los da culpa por fugir e apenas a compaixão e a condescendência poderão salva-los. O "humanitário", no sentido que aqui criticamos, não diz respeito às agências humanitárias ou a instituições em particular, nem se resume às tradicionais figuras do estado, mas, antes, a um modo de gestão compartilhado por diferentes atores, incluindo agências governamentais, organismos supranacionais e instituições não-governamentais. E principalmente a um modo de subjetividade que atravessa as conexões sociais, afetivas e políticas. A questão que merece atenção é a inclusão do humanitário como componente das gestões do governo, especialmente na classificação moral dos sujeitos e na distribuição dos direitos e de cidadania.

\section{1}

\section{A crítica ao paradigma humanitário: a vida diminuída}

Afinal, qual é o problema a ser criticado ou o ponto a ser superado? Que problema pode haver no fato de uma pessoa ser reconhecida refugiada porque ela demonstrou o risco à sua sobrevivência? Porque a sobrevivência não pode justificar seu direito em ser protegida? A sobrevivência não é, afinal, um fato? A tragédia de nosso tempo? E que a razão de estado tenha assimilado as razões humanitárias em suas práticas de gestão, isso não seria algo a celebrar?

Certamente a resposta pode ser afirmativa. E certamente nossa crítica não pretende desfazer os pressupostos positivos da razão humanitária. A questão não é tampouco tornar a resistência como algo a priori, nobre e bom por si só, mas verificar, primeiro, que a lógica humanitária é uma forma de capturar a potência da resistência e enfraquece-la, apresentando a vida como uma dádiva, cuja extensão e valor são concessões do soberano.

A questão é verificar, em primeiro lugar, como a vida "biológica” - e sobretudo, a sobrevida ou a vida no limite - se tornou o centro da política e, em seguida, o ponto de referência da gestão humanitária que compõem o governo do 
biopoder. E como a lógica de governo humanitário pressupõe a neutralização da potência criativa das formas de vida que ela pretende subjetivar.

Os elementos que poderiam anunciar a potência da vida, como o desejo, por exemplo, serão interpretados como a perda da inocência. Apenas ao migrante - e sobretudo o "ilegal” - desejou fugir. Por esta razão, a tentativa de dar conta das complexidades e nuances entre estas tantas figuras - os sujeitos que decidem fugir, por vários motivos - através do nome de “fluxos mistos” apenas tenta, uma vez mais, retomar a classificação, como se os refugiados não afirmassem sua escolha e seu desejo em viver. Como diz o refugiado Charly Kongo, os refugiados “escolheram viver" 32 .

E, por fim, verificar que a questão não é insistir para que o estado recue em sua forma de gestão - retornando ao reconhecimento do "sujeito de direitos" como modelo ideal - mas sim insistir que o direito dos refugiados está baseado em sua luta, como acontece com todos os direitos, que nascem, sempre, dentro e contra o estado.

\section{2}

\section{A ascensão da vida ao centro da política}

A vida se tornou o centro da política desde o surgimento do governo do biopoder, como Foucault anunciou em algumas de suas obras. O homem moderno é um animal em cuja política sua vida, como ser vivo, está em questão (Foucault, 207, p. 113). Ao diferenciar da antiga soberania clássica do novo regime de soberania do biopoder, que afirma a vida e o corpo como centro e fundamento, Foucault aponta sobretudo para a o modo como cada um destes regimes se relaciona com a vida e a morte. Enquanto a soberania clássica decidia a morte, o biopoder decide a vida. No primeiro registro, trata-se de fazer morrer e deixar viver; no segundo, fazer viver e deixar morrer.

No regime da antiga soberania, o súdito carrega a dívida por sua vida e por sua morte diante do soberano. E mais do que a vida, é sobre sua morte que o soberano decidirá; é porque tem o poder de matar que ele exerce o direto sobre

\footnotetext{
${ }^{32}$ Esta é uma afirmação que Charly Kongo, um refugiado congolês que mora no Rio de Janeiro há cerca de oito anos, sempre repete em suas manifestações.
} 
sua vida e é por esta razão que se trata de um regime em que a morte é central e o poder é um direito de “espada” (Foucault, 1999, p. 287). No regime da soberania, que vigorou até os séculos XVII e XVIII, a morte era ritualizada e poderia ser requisitada pelo soberano no estado da guerra. Ela fazia parte dos atos de poder.

Na soberania do biopoder, o direito de fazer morrer cede lugar ao fazer viver. Contudo, o investimento do poder sobre a vida não é um investimento qualquer, mas é, acima de tudo, um modo de expropriação das forças vitais. Diferentemente do regime que sucedeu, o biopoder opera pela otimização das forças que ele pretende submeter, para então apropriar-se de sua produção. E mesmo quando se trata da morte e de deixar (ou fazer) morrer, será em nome da defesa da vida.

E, paradoxalmente, é no regime do biopoder, quando mais se fala da vida, que acontecem as mais terríveis guerras os mais terríveis genocídios (Foucault, 2007a, p. 149). As guerras não se travam mais em nome do soberano a ser defendido, mas em nome da existência de todos e, numa reviravolta, a sobrevivência da humanidade fundamenta a possibilidade de extermínio total pelo poder das armas atômicas.

O poder sobre a vida, a partir do século XVIII, se desenvolveu em duas formas interligadas: uma, centrada no corpo, agindo pelo adestramento e ampliação de suas aptidões, para, ao final extorquir suas forças, no crescimento paralelo de sua utilidade e docilidade; a segunda, desenvolvida pouco mais tarde, é centrada no corpo como espécie e daí todo o interesse pelo tema da população, incluindo temas como reprodução, nascimento, saúde, longevidade, etc. Ao lado da disciplina dos corpos nos quarteis, escolas e prisões, surgem os problemas relacionados à subsistência e ampliação da espécie.

Ao fim do século XVIII, o corpo individual deixa de ser objeto exclusivo do poder e, em seu lugar, os fenômenos populacionais ascendem como foco de interesse. Além do adestramento e docilização dos corpos individuais, o poder cria técnicas de governo para gerir os fluxos populacionais. Isso não quer dizer que o poder sobre o corpo foi abandonado, mas que junto com isso é necessária a gestão das populações.

Como dizem Hardt e Negri, o "biopoder é a forma de poder que regula a vida social por dentro, acompanhando-a, interpretando-a, absorvendo-a e a rearticulando” (2006, p. 43). O poder adquire comando sobre a vida total da 
população quando se torna função integral e vital ao qual todos os indivíduos aderem por vontade própria. E sua função mais elevada é envolver a vida totalmente e administrá-la. O biopoder, portanto, diz respeito a uma situação "na qual o que está diretamente em jogo no poder é a produção e a reprodução da própria vida” (Ibidem).

Enquanto as disciplinas eram dirigidas ao corpo e ao homem enquanto corpo, e o poder tenta organizá-los enquanto indivíduos, a biopolítica tem o homem enquanto ser vivente e enquanto espécie, e dirige-se à multiplicidade dos indivíduos enquanto populações. Quase concomitante à operação de poder sobre o corpo através da individualização, marca do regime disciplinar, surge a tomada de poder massificante, operada sobre o conjunto dos seres e fluxos.

Pela primeira vez a vida entra na história, e o biológico reflete-se no político. Fenômenos da espécie humana, pela primeira vez, entraram na ordem do saber e do poder, no campo das técnicas políticas. A vida, que sempre pressionou a história, principalmente através das epidemias e da fome, só entrou quando estes eventos foram relativamente controlados.

E quando o biológico coincide com o político, o poder não se exerce mais sobre os sujeitos de direito, mas sim sobre os seres viventes, de cuja vida deve se encarregar. Durante milênios, diz Foucault, o homem era aquilo que dele dizia Aristóteles: um animal vivo, capaz de existência política. No regime da moderna soberania, o homem é um animal, “em cuja política, sua vida de ser vivo está em questão” (Foucault, 2007, p. 156).

O poder não se apresenta somente para decidir a morte, se não para encarregar-se de suas vidas. No entanto, a consequência do desenvolvimento do biopoder é a importância crescente da norma: o poder que se encarrega da vida terá necessidade de mecanismos contínuos de regulação e correção. Se o poder abandonou a tarefa de morte, cabe a ele agora distribuir os vivos, determinar hierarquias, medir, avaliar, atribuindo-lhes utilidades. A lei e a norma não desaparecem, mas, ao contrário, se integram na multiplicidade de instituições, incluindo a medicina e a administração.

As técnicas de governo incluem nos cálculos os fenômenos populacionais, considerando a taxa de normalidade das populações, incluindo não apenas os humanos, mas os vírus, as plantações, os migrantes, etc. Governar populações 
implica, assim, em considerar os índices de normalidade e anormalidade de cada uma delas, de modo a garantir a segurança e evitar os riscos ${ }^{33}$.

Foucault sublinha ainda a relação entre estado, biopoder e racismo. Embora o racismo existisse muito antes do biopoder, ele foi o responsável por dar ao racismo um lugar especial dentre os mecanismos fundamentais do estado. Não há funcionamento do estado que, em certo momento, diz Foucault, não passe pelo racismo (Foucault, 1999, p.304). Novamente, o corte entre quem deve viver e quem deve morrer; mas a partir da determinação de quem deve viver, decide-se pela morte da raça inferior e degenerada. É a operação de eliminar não exatamente os adversários, mas os riscos para a população ou para a espécie.

Foi contra esse poder sobre a vida, no entanto, que as lutas se levantaram desde então; e não em nome do retorno aos antigos direitos ou antigos ideais, mas também em nome da vida. Em nome da vida, mais do que em nome dos direitos, que se deram as lutas, ainda que formuladas pela afirmação de direitos, como direito à vida, ao corpo ou à felicidade. Uma réplica, como diz Foucault, incompreensível para o sistema jurídico clássico (Foucault, 2007, p.158).

As investigações de Foucault sobre a gênese da biopolítica guardam relação com a questão do governo e da governabilidade. Em sua descrição genealógica, ele mostra a sequência do governo dos homens ao governo das almas por meio do poder pastoral, até a constituição da "governamentabilidade” política, que é a arte de governar de onde emerge a "razão de estado".

A noção de biopolítica, como afirma Judith Revel (2011, p. 24), exige uma investigação histórica do contexto político em que ela surgiu, isto é, o liberalismo, o modelo de governo que, a partir da lógica da “razão de estado”, não apenas pretende a maximização de seus efeitos, reduzindo seus custos, sobre o modelo de produção industrial, mas que também adota a retórica da mínima intervenção estatal. Esse novo modelo de governabilidade, que não se reduz à mera análise jurídica, nem econômica, se expressa como uma nova tecnologia de poder que terá como objeto o conjunto dos seres vivos.

\footnotetext{
${ }^{33}$ GUIMARAENS, Francisco. “O biopoder e os direitos em Michel Foucault”.
} 


\section{3}

\section{O Estatuto do refugiado e o estatuto da exceção}

Na esteira das análises de Foucault, o filósofo italiano Giorgio Agamben toma a questão da politização da vida para demonstrar que há um ponto de inflexão na modernidade, em que a nudez da vida surge como seu momento decisivo. A vida nua estaria, segundo Agamben, na intersecção entre os dois modelos de poder, o jurídico-institucional e o biopolítico (Pelbart, 2003, p. 61).

Interessa ver como Agambem argumenta sobre a exceção e sobre a vida nua. E como, a seu modo, ele pensa sobre a continuidade entre o poder soberano e o biopoder, especificamente a partir do ponto da incidência do poder sobre a vida nua. A biopolítica, como ele sustenta, seria tão antiga quanto a exceção soberana. E o estado moderno, colocando a vida no centro de seus cálculos, apenas confirma o vínculo secreto que une o poder à vida nua.

Agamben quer demonstrar que tomar a vida biológica como fundamento da política prova justamente a continuidade do soberano arcaico: a decisão sobre a morte ainda é uma prerrogativa do poder. Conectando as investigações de Foucault com o trabalho de Hannah Arendt, ele pretende mostrar que do ponto de vista histórico e filosófico, os regimes contemporâneos de soberania e poder, incluindo o nazismo e a democracia liberal, apoiam-se sobre o mesmo conceito de vida nua.

A biopolítica do totalitarismo moderno, de um lado, e a sociedade de consumo, do outro, constituem modos que se comunicam. E o que caracteriza a democracia moderna seria justamente a tentativa de transformar a vida nua em vida qualificada, ou, nos termos de Agamben, encontrar o "bios" da "zoé". O paradoxo neste encontro, contudo, é que toda vez que a democracia aponta para as liberdades e direitos há uma crescente inscrição das vidas na ordem estatal.

Agamben conecta a qualidade mais arcaica do poder ao mais moderno, para dizer que o soberano sempre tem a prerrogativa de decidir, num estado de exceção, qual vida pode ser extinta, sem que se possa falar em crime. No regime biopolítico, esse poder se emancipa do extado de exceção para se transformar no poder de decidir o momento em que a vida deixa de ser politicamente pertinente.

A propósito, ele já havia utilizado a figura do refugiado para pensar o ressurgimento da vida nua na cena política do mundo pós-guerras (2002). Ao 
mesmo tempo em que funda sua existência sobre a vida nua, o refugiado anuncia o campo (de refugiados) como território pleno do biopoder, o local privilegiado da exceção: pedaços de território colocados fora do ordenamento jurídico normal. Inicialmente apresentado como algo provisório, mas que se estende indefinidamente.

Referindo-se às reflexões de Hannah Arendt (1998), Agamben argumenta que a nudez política da vida, isto é, o puro fato de serem humanos, assinala definitivamente a crise radical dos direitos do homem. Isso significa que a vida nua não é a base para os direitos do homem. Quando desaparece para o homem o nexo entre nascimento e nacionalidade, dizia Arendt, fundamento para o conceito da soberania e da cidadania, aquilo que resta da vida não é suficiente para garantir-lhe um lugar seguro no mundo.

No sistema do estado-nação, segundo a linha de pensamento de Agamben, os direitos do homem não permitem qualquer tutela enquanto não se possam configurá-los como direitos do cidadão de um determinado estado. A vida, enfim, abandonada à sua natureza original, de vivente, não é garantia de sua própria preservação. O ingresso da zoé na esfera da pólis, diz ele, ou a politização da vida nua, é o evento decisivo da modernidade, assinalando uma transformação radical no modo como se pensava e teorizava a filosofia política.

A implicação da vida nua na esfera política - na pólis - constitui o núcleo originário, mesmo que encoberto, do poder soberano. Também o poder soberano tem esta característica paradoxal, da exclusão pela inclusão. E desta forma, entre o homo sacer e o soberano há esta incrível coincidência. Se de um lado a vida nua isto é, o homo sacer, a vida matável, porém insacrificável - prova a inclusão da vida humana no ordenamento unicamente sob a forma de sua exclusão, o soberano é, por sua vez, aquele que decide pelo estado de exceção, ou seja, a sua inclusão no mundo se dá pela sua própria exclusão do ordenamento. Em ambos os casos, a inclusão pela exclusão, mas, no caso do soberano, o poder da decisão está em suas mãos.

A vida como locus privilegiado da política, fenômeno ao qual Michel Foucault dará o nome de biopolítica, é, como conclui Agamben, tão antigo quanto a exceção soberana. O que caracteriza, assim, a politica moderna não é a inclusão da vida biológica na cidade, ou o fato de que a zoé torne-se objeto principal dos cálculos e das ações do poder estatal. O fato decisivo, para Agamben, é que ao 
lado do processo pelo qual a exceção se torna regra, a vida nua - em sua origem, situada à margem do ordenamento - passe a coincidir com o espaço político e, desta forma, inclusão e exclusão, bios e zoé, entrem em uma zona de indistinção. A conclusão é que o estado de exceção, condição em que a vida nua é simultaneamente objeto de exclusão e captura, constitui o fundamento oculto sobre o qual repousa o sistema político.

O que marca definitivamente a biopolítica moderna, portanto, é esta necessidade de redefinir continuamente o limiar que separa o que está dentro e o que está fora da vida, isto é, o limiar que permite ver qual é a vida sacra. E na medida em que a vida natural é cada vez mais incluída na pólis, o limiar tende a se deslocar continuamente, além das sombrias fronteiras que separam a vida da morte. E se o campo de concentração foi o lugar por excelência onde o estado de exceção se torna regra, os campos de refugiado - e a própria definição de refugiado - ilustra, de maneira clara, a atualização dos novos limiares em que a vida é incluída pela exclusão.

O campo de refugiados é o lugar em que a proteção somente é possível porque a inclusão se opera pela exclusão e a exceção se torna a norma. Da mesma forma, o refugiado é aquele cuja definição assinala sua inclusão (no sistema de proteção) porque sua ligação com o Estado tornou-se frágil o bastante para que lhe restasse apenas a nudez da vida.

Acompanhamos Agamben e sua reflexão sobre a vida nua e sobre a exceção até o ponto em que seja possível fazer um desvio. As diferentes experiências concretas nos mostra que, não raras vezes, a exceção não é determinada pela ausência da regra e da lei, mas justamente por seu exercício. E, de outro lado, tomar a exceção sempre em sua expressão negativa nos levaria a recusar e a negar a produção de vida nascida das lutas e nas linhas de fuga.

Neste sentido, acompanhamos sua reflexão sobre a vida nua para comprovar que ela serve como justificativa para as políticas de recusa da vida como resistência. A vida nua é justamente aquela vida criada pelas máquinas de produção de subjetividade que tomam este conceito como uma verdade a priori, recusando muitas e diversas formas de resistência.

Da forma como a apresenta, a vida nua, segundo Agamben, está suposta na distinção entre homem e natureza, como instâncias separadas e puras. Como se a natureza estivesse no mundo separada da cultura e como se a cultura existisse 
como uma dimensão fora da natureza. Sempre como algo a mais e mesmo como algo impuro. E como se a vida pudesse ser caracterizada como algo meramente biológica. Como se a vida mesma não fosse artifício e natureza, ao mesmo tempo. E sobretudo, resultados de inúmeros conflitos. Essa separação, que ele toma como pressuposto e se torna sua grande afirmação, recusa, no entanto, que a vida não existe, nem nunca existiu fora da cultura, nem fora da natureza.

De outra parte, a vida nua não pode ser, como faz Agambem, a constatação da vida absolutamente impotente. Sem recusar a dor dos refugiados e das pessoas que sofrem as mais duras formas de violência, é possível qualificar a vida apesar e a despeito da impotência. Justamente por não se recusar nem a dor nem a tragédia. O fato é que no último respiro de vida ainda há resistência. O mero fato da sobrevivência já encarna, em si, a vida como afirmação vital e política. A vida sempre tem a possibilidade e, portanto, a vida sempre escolhe resistir, para além do esmagamento do poder. Do contrário, a vida nua seria a celebração da morte.

Se o poder passa a incidir diretamente sobra vida, decidindo investir na produção de vida e tendo a morte como decisão subsidiária, e se o ser vivente, enquanto fenômeno populacional, se torna o centro do interesse deste mesmo poder, isso não quer dizer que a vida se faz passivamente. E se a vida não é outra coisa se não a força de resistir - e por isso concordamos que a resistência é antecedente e constituinte - é porque a resistência não é reativa ao poder.

As lutas, como dizia Foucault (2006, p. 276) vêm antes do próprio poder e são elas que põem em marcha as relações de poder, pois determinam os meios institucionais pelos quais o poder passa. As relações de poder estão em constante mutação, por causas que estão situadas fora delas, enquanto que as lutas acontecem no interior dos dispositivos e instituições criados pelas relações de poder.

O poder, por sua vez, como diz Foucault (Ibidem), não existe como categoria ontológica ou como um universal. Não existe o poder com P maiúsculo, contra o qual se submetem os indivíduos, coagidos por sua força irresistível. O poder nasce de uma pluralidade de relações "que se enxertam em outra coisa, nascem de outra coisa e tornam possível outra coisa” (Ibidem). 


\section{4}

\section{A vítima como paradigma e o governo da compaixão}

Ao lado da crítica formulada pela denúncia da ascensão da vida nua ao centro da política, pode se acusar a eleição do sofrimento como fundamento para o direito e, portanto, da compaixão e da condescendência como fundamentos do sujeito político. Nesta acusação, algumas críticas apontam a retórica dos direitos humanos como uma “antipolítica”, como faz Costa Douzinas (2015) ${ }^{34}$, ou como uma nova teologia de estado, cujo principal efeito é apagar as desigualdades responsáveis pelo sofrimento e pela violência, como diz Didier Fassin (2012). De certo modo, todas denunciam o mesmo processo de enfraquecimento da política e a transformação daquilo sobre o qual se fundava o "sujeito de direitos”.

O "humanitarismo" surge justamente neste regime de valorização do humano como vivente, como mera vida biológica. Na França, demonstra Fassin ${ }^{35}$, enquanto se reduz diminui o número de deferimentos de pedidos de refúgio, aumenta o número de vistos "humanitários” baseados em razões médicas. Em 1980, enquanto o número de deferimentos de refúgio chegava a dez mil, as autorizações de visto por razões humanitárias representavam algumas dezenas de casos. Em apenas dez anos, o número de vistos por razões humanitárias era igual ao de refugiados. Em pouco tempo, os vistos por razões humanitárias tornam-se prioridade em relação ao refúgio.

O governo "humanitário", como se vê, está assentado sobre este direito humano abstrato, e a verdade revelada pelos corpos despolitizados é a única forma de legitimar os direitos. Eis a humanização que escancara a vida nua como ponto central de ação do poder, de modo que o refugiado, figura que corresponde à crise radical do sujeito de direitos. Por isso mesmo, o humanitarismo é criticado como o soterramento da resistência política, na mesma medida em que a vítima, mesmo como virtualidade, o sofrimento e a compaixão acendem ao centro do palco.

O direito à vida é definido como um direito ligado a uma causa externa, transcendente e que em última análise depende da soberania. Na ficção forjada

${ }^{34}$ DOUZINAS, Costas. “As Muitas Faces do Humanitarismo”, Revista Direito \& Praxis, vol. 06. N.11, 2015, p. 375-424.

${ }^{35}$ FASSIN, Didier. "La Souffrance du monde. Considérations Anthropologiques sur les Politiques Contemporaines de La Compassion”. Évolution Psichyatrique, 67, PP. 676-89. 2002. 
pelo poder, os homens cedem seus direitos ao soberano, renunciando a existir em troca de seu sagrado direito à vida, expondo assim seu corpo matável à violência do direito estatal ${ }^{36}$.

Como aponta Douzinas, citando Alain Finkierklraut ${ }^{37}$, “a geração humanitária não gosta do homem - eles são muito desconcertantes --, mas gosta de tomar conta deles. Homens livres assustam. Ansiosa para expressar ternura enquanto assegura que o homem não irá fugir, ela prefere pessoas debilitadas”. Atingido pela retórica humanitarista, o principal objetivo da política torna-se, então, ainda argumentando com Douzinas, restringir o mal e aliviar o sofrimento.

O humanitarismo, apresentando-se como a antipolítica, atribui a si a única imparcialidade e neutralidade que permite direitos iguais para todos os humanos. Não por acaso, o governo humanitário surge justamente após o colapso das possibilidades reais de comunismo e com a ascensão triunfante do neoliberalismo (Fassin, 2012, p. 14 e Douzinas, 2015, p. 415).

A crítica que faz Fassin (2012) é neste mesmo sentido: a mobilização coletiva da compaixão, como elemento central da política e da governabilidade, não apenas pretende tomar o lugar dos tradicionais conflitos políticos, mas de fato apaga a memória da exploração e da desigualdade que estão por trás das lutas e dos conflitos.

Ao mesmo tempo em que o mundo se comovia com as vítimas do terremoto no Haiti, em 2010, com mobilização de governos e de organizações nãogovernamentais, deslocamento de grandes investimentos - de dinheiro, ajuda emergencial, tropas, remédios, comidas, etc -- trinta mil haitianos estavam na lista de deportação nos Estados Unidos da América. E na França, apenas 6\% dos pedidos de refúgio feitos por haitianos foram aceitos. A compaixão pelos haitianos sequer foi capaz de lembrar os cidadãos franceses e norte-americanos sobre a exploração violenta que seus governos impuseram contra a ilha (Fassin, 2012, p. xii).

Fassin, para quem o "governo humanitário" -- em sentido amplo, incluindo não apenas as práticas das agências do estado, mas as administrações locais,

${ }^{36}$ CAVA, B. \& MENDES, F.A. “A vida dos direitos - violência e modernidade em Foucault e Agambem”, Revista Filosofia Polícia do direito, Rio de Janeiro: Núcleo de Pesquisa Lyrian, Agon, 2008.

${ }^{37}$ FINKIERLKRAUT, Alain. In the name of humanity. Nova Iorque: Colunbia University Press, 2000, p. 91. 
órgãos internacionais, organizações não-governamentais, dentre outras, -utilizando sentimentos morais para definir a política de governo como forma de gerir e regular o comportamento dos indivíduos, demonstra, ao final, suas contradições e mesmo seu cinismo: utilizando a linguagem de sentimentos morais, o governo humanitário implementa políticas que aumentam as desigualdades sociais e restringem os direitos das minorias, incluindo os migrantes e refugiados. Focada principalmente nos pobres e mais vulneráveis, a política de gestão humanitária é a política da desigualdade.

A desigualdade surge, primeiro, pela assimetria essencial na relação entre o doador e o beneficiário, pela humildade com que as minorias são obrigadas a se comportar e responder diante de seus benfeitores. Em segundo, a gestão da compaixão faz aparecer a desigualdade pela neutralização, fazendo dos sujeitos meros beneficiários, tirando-lhes a capacidade de demandar por direitos. A assimetria, assinala Fassin (2012, p. 04), não é uma questão psicológica, mas política e, portanto, a gestão humanitária é de fato a política da vida precária.

E, por fim, a compaixão funciona como elemento de neutralização da memória sobre as assimetrias e injustiças, restando apenas a dor e a condescendência como possibilidade de política. A desigualdade, assim, é naturalizada nesta operação em que a igualdade é dada pela equivalência do sofrimento. Se todos podem sofrer, todos são iguais e, portanto, a gestão é uma gestão do sofrimento e da dor: a vítima é o sujeito emblemático do governo humanitário e sua inocente vulnerabilidade o princípio e o fim da política.

\section{5}

\section{A inocência e o corpo no limite}

Fassin narra a história da jovem mulher haitiana que teve seu pedido de refúgio (asilo) rejeitado pelo governo francês (2012, p. 141). O pedido, endereçado, em 2000, ao Escritório Francês de Proteção dos Refugiados e Apátridas $^{38}$ foi rejeitado. E novamente negado pela instância recursal (Comissão de Recurso para Refugiados ${ }^{39}$ ). Seu pedido de refúgio estava baseado na

\footnotetext{
${ }^{38}$ No original, em francês "Office Français de Protection des Réfugiés et des Apatrides".

${ }^{39}$ No original, Commission des Recours des Réfugiés.
} 
perseguição política que sua família sofria no Haiti: seu pai foi assassinado, sua mãe foi desaparecida e ela tinha sido vítima de terríveis violências sexuais depois que os perseguidores invadiram sua casa. $\mathrm{O}$ pedido foi negado porque, de acordo com as autoridades, não ficou provado que seu estupro tivesse motivação política. Decidiram que se tratava de violência comum, não protegida pelo instituto do refúgio.

Naqueles anos, os pedidos de refúgio apresentados pelos haitianos tinham poucas chances de sucesso: apenas 3,3\% eram aceitos em primeira instância e 3,8\% em segunda, a despeito do conflito no Haiti, do regime de terror instaurado e da instabilidade política (Fassin, 2012, p. 142). Como a maior parte dos solicitantes de refúgio que têm seu pedido negado, a jovem haitiana se tornou uma migrante "ilegal" e passou a viver de modo clandestino, sujeitando-se a trabalhos pesados e a uma vida de dificuldades.

Em dois anos, ela perdeu muito peso e aparentava severa depressão. Depois de consultar um psiquiatra - que havia diagnosticado a depressão e risco de suicídio - e passar por exames, descobriu-se que ela era portadora de HIV e que seu sofrimento físico era resultado do estado avançado da síndrome. Com base no laudo, ela facilmente obteve documentos de residência, como grande parte dos haitianos que pediram residência na França com base em laudos médicos. Os haitianos, a propósito, eram o terceiro maior grupo de solicitantes de residência por questões médicas no país, principalmente por causa de AIDS.

A cidadania inicialmente rejeitada a ela como refugiada, foi obtida por razões humanitárias. E, se suas palavras não foram suficientes para convencer as autoridades sobre a violência que sofreu, foi preciso que seu corpo falasse por ela (Fassin, 2012, p. 142). Mas, acrescentaríamos, não era apenas um corpo ou qualquer corpo, e sim o corpo doente, nos limites de sua potência, na fronteira entre vida e morte.

A jornada e o destino da jovem haitiana, no entanto, como nos conta Fassin (2012, p. 143), não era uma exceção. De fato, em duas décadas, uma verdadeira mudança aconteceu na França em relação à garantia de proteção aos refugiados e à documentação dos migrantes "humanitários”. No início dos anos 1980, havia cerca de 20 mil pedidos de refúgio por ano, dentre os quais 75\% eram aceitos, o que representava cerca de 15 mil. No início dos anos 1990, no entanto, apesar do número de solicitações subir para cerca de 80 mil por ano, apenas $15 \%$ foram 
deferidos, correspondendo a 13 mil pedidos: mesmo em termos absolutos, era um número menor do que antes.

Os números, nas décadas seguintes, continuaram a decrescer, como efeito dos esforços para diminuir a chegada e o acesso dos solicitantes de refúgio nos pontos de entrada do país. E mesmo com as medidas “seletivas” para restringir a chegada, a taxa de deferimentos continuou baixando. No início da década de 2000, apenas 7,8\% dos pedidos foram aceitos, o que significava apenas três mil refugiados reconhecidos. Em duas décadas, o governo francês passou a aceitar apenas um quinto do número de refugiados. O efeito secundário desta mudança foi o aumento brutal do número de migrantes indocumentados ou em situação irregular: apenas no período entre 2003 a 2007, eram 171 mil pessoas.

\section{6}

\section{O espetáculo das vítimas e os bastidores da guerra}

O corpo do pequeno Aylan Kurdi abriu os olhos do mundo para a tragédia dos refugiados sírios e se tornou uma das imagens mais emblemáticas da atual crise dos refugiados. Na sequência da morte de Aylan, no entanto, mais de 100 crianças se afogaram no Mediterrâneo e mais de um milhão de refugiados entraram na Europa, sendo que pelo menos metade deles é composta por sírios. Somente no início de 2016, foram contabilizadas 25 pessoas mortas no Mar Egeu, incluindo 18 crianças, que morreram quando o barco em que usavam para chegar à Grécia naufragou. Dez pessoas foram resgatadas e levadas ao hospital ${ }^{40}$. Mas a guarda costeira não sabe exatamente quantas pessoas havia no barco. Dias antes, 43 pessoas - a maioria mulheres e crianças -- morreram no mesmo lugar, quando dois barcos se chocaram com a costa da pequena ilha de Farmakonisi ${ }^{41}$.

De acordo com a ONU, mais de 46 mil pessoas chegaram à Grécia até o final de janeiro (28/01/2016), uma das principais portas de entrada para o continente europeu. Aproximadamente três mil pessoas chegam diariamente ao

\footnotetext{
40 “Dozens die in refugee boat disaster off Greek island”. Al Jazeera. 28/01/2016. (Disponível em http://www.aljazeera.com/news/2016/01/160128082306824.html). (Último acesso em 28/01/2016).

41 "Refugees drown as two boats capsize off Greek islands”. Al Jazeera. 23/01/2016.( Disponível em http://www.aljazeera.com/news/2016/01/refugees-drown-boats-capsize-greek-islands160122100827699.html). (Último acesso em 28/01/2016).
} 
país, apesar do frio do rigoroso inverno. Mais de 170 morreram na travessia marítima. Ao mesmo tempo, a crise econômica no país deixou 1.500 atenienses sem casa, estima Praksis, uma ONG grega ${ }^{42}$. Mais de 500 mil pessoas passaram a viver em "condições inadequadas ou precárias" Na região local de Attica, vivem sem água ou eletricidade, por exemplo, ou em abrigos. Por sua vez, os problemas associados com a pobreza e a falta de moradia, como o uso de drogas e o tráfico, estão crescendo rapidamente. Este é o cenário do país europeu onde mais chegam refugiados.

Enquanto o policial turco levantava seu corpo do chão - a imagem mais dramática dentre várias desta crise -- um dos primos de Aylan viajava sozinho em um ônibus, na Hungria, fugindo da guerra em Damasco ${ }^{43}$. Dias depois da morte do garoto, uma de suas tias se preparava para fazer a mesma travessia, junto com seus filhos. E outros primos trabalham em turnos de dezoito horas em uma oficina clandestina de costura, em Istambul, para garantir a sobrevivência da família.

A família de Aylan tem sua história atravessada por êxodos. Pertenciam a um clã de etnia curda, bastante oprimida na Síria. Para a maioria de seus familiares, a vida em Damasco fazia da questão étnica algo irrelevante. A filiação étnica, após a guerra, se tornou importante. Na verdade, uma questão de vida e morte. Seu avô nasceu em Kobate, um enclave curdo na fronteira com a Turquia. Depois de cumprir o serviço militar, mudou-se para Damasco e se instalou em um bairro de predominância curda. Abriu um salão de cabelereiro e se casou com uma mulher curda. Tiveram seis filhos e alguns deles abandonaram a escola para seguir seu ofício.

Fátima, a mais velha, migrou em 1992 para o Canadá e se casou com um curdo iraquiano. Divorciou-se, conseguiu uma vida estável e, quando veio a guerra, ajudou a amparar a família. Quando o mundo conheceu a história de Aylan, Fátima entrou em ação e, a partir de sua nova casa, no Canadá, passou a acusar a burocracia canadense e a indiferença do mundo em relação aos sírios.

\footnotetext{
42 “Greek refugee crisis: 'we need coordinated action'”. The Guardian. Adam Smith. 04/11/2015. (Disponível em http://www.theguardian.com/global-development-professionalsnetwork/2015/nov/04/greek-refugee-crisis-we-need-coordinated-action). (Último acesso em 25/01/2016).

43 "Escape del infierno: la tragedia de la familia de Aylan, símbolo de la desesperación por la guerra en Siria”. La Nacion. Anne Barnard. 30/12/2015. (Disponível em http://www.lanacion.com.ar//1858084-escape-del-infierno-la-trage). (Último acesso em 22/01/2016).
} 
Depois, foi à Europa para participar de campanhas em favor dos refugiados. Tornou-se símbolo da luta pelos refugiados, depois que o país que a acolheu rejeitou a entrada de Aylan e seus familiares.

O pai de Aylan se culpa pela morte de seus dois filhos e da esposa e gostaria voltar no tempo para não entrar no navio fatídico. Foi ele quem assumiu o comando no caos quando o navio foi engolido pelas águas. Antes mesmo de acusar a si mesmo, as autoridades europeias tentaram responsabilizá-lo pela tragédia, seguidas pela imprensa ${ }^{44}$. Não foi sequer preciso ignorar a comoção em relação à criança, mas aproveitá-la para montar uma acusação. Seu pai, que colocou a si e sua família em fuga, buscando proteção, foi apontado como autor da morte do filho que tentava salvar.

Tragédia semelhante aconteceu, muitos anos antes, com dois adolescentes que tentavam chegar a Bruxelas depois de deixar Guine Conacri, seu país de origem. Este incidente descrito por Fassin (2012, p. 254/255), ocorrido em 1999, ilustra o paradoxo da política sobre a vida e o regime humanitário como uma das faces do governo do biopoder.

Os corpos dos dois garotos foram encontrados próximo ao trem de pouso do avião em que tinham entrado clandestinamente. Mortos por asfixia ou hipotermia, um deles tinha uma carta nas mãos, destinada às autoridades europeias. A enorme emoção causada tragédia envolvendo os dois adolescentes, principalmente na Bélgica, onde poucos meses antes uma jovem mulher nigeriana foi sufocada por policiais que tentavam devolvê-la ao seu país de origem, não tinha relação apenas com a jornada intercontinental de garotos tentando fugir da pobreza e da violência. Como diz Fassin (2012, p. 256), a comoção tinha a ver também com o conteúdo da carta, que apelava diretamente aos sentimentos morais das autoridades europeias e certamente atingia a todos os cidadãos europeus.

A carta, utilizando o vocabulário e a retórica humanitária, mais do que demonstrar a evidente desigualdade entre a situação de vida dos jovens e a do governo a quem recorriam - e eventualmente dando margem a interpretações

\footnotetext{
44 "Syrian toddler Aylan's father drove capsizes boat, passengers say". Reuters. 11/09/2015. (Disponível em http://www.reuters.com/article/us-europe-migrants-turkey-iraqidUSKCNORB2BE20150911) (Último acesso em 11/04/2016) e "Aylan Kurdi's father denies claims he was a people smuggler and driving boat that capsized and led to son's death". Independent. 13/09/2015 (Disponível em http://www.independent.co.uk/news/world/middleeast/aylan-kurdi-s-father-denies-claims-he-was-a-people-smuggler-and-driving-boat-that-capsizedand-led-10498798.html) (Último acesso em 11/04/2015).
} 
depreciativas que poderiam ver na carta a postura humilhante de jovens apelando pelo paternalismo neocolonial - jogava luz justamente sobre a verdade dos direitos humanos e sobre a vocação humanitária do governo europeu.

Eles abrem a carta invocando o próprio sofrimento e o sofrimento de seu povo, (“ajude-nos, nós estamos sofrendo enormemente”), e então apelavam ao sacrifício e à vida (“estamos expondo nossas vidas ao sacrifício”), mas também à linguagem própria do humanitarismo, pedindo engajamento das autoridades europeias ("para combater a pobreza e por fim à guerra”) ${ }^{45}$. A grande força da carta está sobretudo na habilidade que tiveram os dois jovens em lançar de volta aos europeus as imagens que eles utilizam para falar de sua própria posição no mundo e porque, como diz Fassin (2012, p. 256) eles provaram a impotência dos europeus em agir conforme as imagens e palavras que insistem em utilizar.

Tão trágico quanto a morte dos jovens, é que a comoção que eles causaram não foi sequer suficiente para impedir que um jovem senegalês que milagrosamente sobreviveu a uma jornada semelhante - de Dacar a Lion - fosse

\footnotetext{
${ }^{45} \mathrm{O}$ conteúdo integral da carta segue no idioma original:
}

"Excellences, Messieurs les membres et responsables d'Europe,

Nous avons l'honorable plaisir et la grande confiance de vous écrire cette lettre pour vous parler de l'objectif de notre voyage et de la souffrance de nous, les enfants et jeunes d'Afrique. Mais tout d'abord, nous vous présentons les salutations les plus délicieuses, adorables et respectées dans la vie. A cet effet, soyez notre appui et notre aide. Vous êtes pour nous, en Afrique, ceux à qui il faut demander au secours.

Nous vous en supplions, pour l'amour de votre continent, pour le sentiment que vous avez envers votre peuple et surtout pour l'affinité et l'amour que vous avez pour vos enfants que vous aimez pour la vie. En plus, pour l'amour et la timidité de notre créateur Dieu le tout-puissant qui vous a donné toutes les bonnes expériences, richesses et pouvoirs de bien construire et bien organiser votre continent à devenir le plus beau et admirable parmi les autres.

Messieurs les membres et responsables d'Europe, c'est de votre solidarité et votre gentillesse que nous vous crions au secours en Afrique. Aidez-nous, nous souffrons énormément en Afrique, nous avons des problèmes et quelques manques au niveau des droits de l'enfant. Au niveau des problèmes, nous avons la guerre, la maladie, le manque de nourriture, etc. Quant aux droits de l'enfant, c'est en Afrique, et surtout en Guinée nous avons trop d'écoles mais un grand manque d'éducation et d'enseignement. Sauf dans les écoles privées où l'on peut avoir une bonne éducation et un bon enseignement, mais il faut une forte somme d'argent. Or, nos parents sont pauvres et il leur faut nous nourrir.

Ensuite, nous n'avons pas non plus d'écoles sportives où nous pourrions pratiquer le football, le basket ou le tennis. C'est pourquoi, nous, les enfants et jeunes Africains, vous demandons de faire une grande organisation efficace pour l'Afrique pour nous permettre de progresser. Donc, si vous voyez que nous nous sacrifions et exposons notre vie, c'est parce qu'on souffre trop en Afrique et qu'on a besoin de vous pour lutter contre la pauvreté et pour mettre fin à la guerre en Afrique. Néanmoins, nous voulons étudier, et nous vous demandons de nous aider à étudier pour être comme vous en Afrique.

Enfin, nous vous supplions de nous excuser très très fort d'oser vous écrire cette lettre en tant que Vous, les grands personages à qui nous devons beaucoup de respect. Et n'oubliez pas que c'est à vous que nous devons nous plaindre de la faiblesse de notre force en Afrique.

Ecrit par deux enfants guinéens, Yaguine Koita et Fodé Tounkara”. 
enviado de volta ao seu país. E que morresse, então, em sua segunda tentativa de fazer a mesma viagem. É Fassin (2012, p. 257) quem diz: "se tivessem sobrevivido à fatal jornada, a razão de estado teria uma vez mais prevalecido contra eles, sobre a razão humanitária à qual eles tinham apelado”.

\section{7}

\section{Sofrimento como paradigma e a dissimulação das desigualdades}

De modo paradoxal, a vida alçada como fundamento da política significa que ela pode justificar o desprezo pelos vivos. Diante de um trágico acidente com migrantes que naufragaram, o governo italiano reconheceu cidadania aos mortos, enquanto tantas outras pessoas continuavam enfrentando riscos para fugir. Em outubro de 2013, cerca de 400 pessoas morreram no Mediterrâneo tentando chegar à pequena ilha de Lampedusa, porta de entrada para o continente europeu.

Em menos de dez dias, foram dois incidentes, que vitimaram principalmente mulheres e crianças. No primeiro, 366 pessoas morreram, e no segundo, dias depois, 34 cadáveres foram encontrados no mar, enquanto 200 pessoas eram recolhidas com segurança ${ }^{46}$. As autoridades italianas responderam aos incidentes, mandando à prisão um jovem tunisiano apontado como responsável pelo "tráfico" dos “migrantes”, culpado também pelo naufrágio. Quanto ao segundo incidente, diante da comoção pública, o governo italiano decidiu dar cidadania aos mortos e liberou ajuda financeira para os serviços de acolhimento a refugiados.

Em relação aos sobreviventes, no entanto, eles aguardam uma decisão sobre seu destino ${ }^{47}$, mas contaram sobre a violência por qual passaram antes de chegar: foram submetidos a torturas, humilhações e violência sexual. Garotas foram

\footnotetext{
${ }^{46}$ As notícias podem ser encontradas na versão digital do jornal The Guardian ("Lampedusa boat tragedy: survivor's story”) de 22/03/2014, (disponível em http://www.theguardian.com/world/2014/mar/22/lampedusa-boat-tragedy-migrants-africa)do jornal The Telegraph ("Italy mourns 300 dead in Lampedusa boat migrant tragedy"), de 04/10/2013(disponível

"http://www.telegraph.co.uk/news/worldnews/europe/italy/10355661/Italy-mourns-300-dead-inLampedusa-migrant-boat-tragedy.html) (Último acesso em 03/04/2016).

${ }^{47}$ A notícia foi publicada na imprensa internacional: "Italy boat sinking: hundreds feared dead off Lampedusa”. BBC News, 03/10/2013 (disponível em http://www.bbc.com/news/world-europe24380247); “Italy grants citizenship to Lampedusa dead”. EUobserver. 07/10/2013 (Disponível em https://euobserver.com/justice/121681); e "The Lampedusa hypocrisy: Italy prefers its migrants dead on arrival”. The Spectator. 10/10/2013 (Disponível em http://blogs.spectator.co.uk/2013/10/the-lampedusa-hypocrisy-italy-prefers-its-migrants-dead-onarrival/).(Último acesso em 03/04/2016).
} 
seguidamente estupradas por vários homens, e aqueles que não tinham bens suficientes para entregar aos milicianos foram espancados ${ }^{48}$. Esta era uma das poucas rotas “seguras” para chegar à Europa, graças ao fechamento das fronteiras e aumento do controle migratório. O governo dos sobreviventes pode ser também o governo da morte.

Na França, ficou famoso o caso de Leonarda Dibrani, uma estudante de 15 anos, de origem cigana, deportada com a família para o Kosovo. Dibrani foi detida em uma excursão escolar, em outubro de 2013, diante dos colegas de classe. O caso ganhou mais publicidade, principalmente depois que milhares de estudantes protestaram contra o governo. As autoridades recuaram, mas Dibrani, no entanto, não aceitou a oferta de retornar à França sem a família, que já vivia no país há quase cinco anos, depois de terem fugido da discriminação no Kosovo. Sua família teve três pedidos de asilo recusados e estava a poucos meses de conseguir a residência legal ${ }^{49}$.

48 "Eritrean survivor of Lampedusa tragedy returns to honour the dead, meet Pope Francis". UNHCR, 02/10/2014 (disponível em http://www.unhcr.org/542d0ece5.html); e "Mediterranean migrant deaths: a litany of largely avoidable loss. The Guardian. 03/10/2013 (Disponível em http://www.theguardian.com/world/2013/oct/03/mediterranean-migrant-deaths-avoidable-loss). (Último acesso em 03/04/2016).

49 "Roma girl Leonarda Dibrani loses France residency bid". BBC News. 28/01/2014. (http://www.bbc.com/news/world-europe-25936784). "Migration Debate: Deportation Scandal Grips France”. Spiegel Online International. 28/10/2013 (http://www.spiegel.de/international/europe/french-minister-defends-decision-to-deport-roma-girland-family-a-929059.html). "Deported Roma girl's family denied residency. IOL. 28/01/2014 (http://www.iol.co.za/news/world/deported-roma-girls-family-denied-residency-1638234) (Último acesso em 09/04/2016). 


\title{
3.
}

\section{Razões humanitárias e gestão global dos refugiados}

\begin{abstract}
"Inclusive dentro da escravidão capitalista, ainda somos rebeldes, fugitivos, nós nos tornamos selvagens. Ser móveis, inteligentes, possuir linguagens, ser capazes de liberdade, não é um dado natural, é uma potência maquinal, ou produto de uma resistência criativa”.
\end{abstract}

Antonio Negri ${ }^{50}$

A crítica ao governo humanitário se torna ainda mais relevante quando se considera sua escala global. Acompanhando ainda as críticas de Fassin (2012, p. 253), é importante perceber que a gestão do refúgio, em sua dimensão global, precisa encontrar formas de lidar com aquilo que é resultado de seu mecanismo constante de classificação e divisão: de um lado, o campo e os enormes fluxos de refugiados, e, de outro, os solicitantes de refúgio.

No primeiro caso, enormes multidões de pessoas, massas indiferenciadas ou filas de pessoas marchando em longas jornadas. O destino destas pessoas, em primeiro lugar, são os campos montados dentro do próprio país. São os deslocados internos. Em seguida, há os fluxos de refugiados que fogem para os países vizinhos. De modo geral, estes fluxos se dirigem para os países mais pobres - ou os países “em desenvolvimento" - e o tratamento aos refugiados são as tendas, as pulseiras de identificação e os cartões para alimentação e medicamentos.

No segundo caso, são os solicitantes de refúgio, ou seja, os sujeitos individualizados chegando às grandes cidades dos países mais "desenvolvidos”, misturando-se aos fluxos de migrantes - por isso, o nome de "fluxos mistos". Aos solicitantes de refúgio, o tratamento é individualizado: é preciso fazê-los confessar suas razões, analisar sua boa fé, julgar sua inocência e decidir se são merecedores do status. Cada caso merece uma análise individualizada e meticulosa, sob o risco de se dar a alguém que não merece um status excepcional. É a retórica da escassez, justificada pela necessidade de se evitar, a todo custo, a "banalização"

${ }^{50}$ NEGRI, Antonio. "Biocapitalismo: entre Spinoza e a contribuição política do presente”. São Paulo, Ed. Iluminuras, 2015, pág. 64. 
do refúgio, preservando o instituto do uso inadequado por parte dos migrantes. $\mathrm{E}$ para isso é preciso então gerir sua excepcionalidade.

\section{1}

\section{Desigualdade como regra}

Dentre os dez países que mais recebem refugiados, oito são apontados como nações “em desenvolvimento" e dois como “países industrializados” ${ }^{51}$. O Paquistão e o Irã são os países que mais receberam refugiados em 2015: o primeiro com 1,5 milhões (a maioria vinda do Afeganistão) e o segundo com 951.000. Em seguida, vem Somália, com 1,1 milhões, Quênia (onde há décadas está montado um dos maiores e mais antigos campos do mundo: Daadab), com 418.900, Iêmen, com 249.000 e Etiópia, com 247.300 pessoas refugiadas. Embora a Turquia seja o país com maior número absoluto de pessoas refugiadas, seguido pelo Paquistão e Líbano, cinco países subsaarianos recebem a maior parte de todos os refugiados do mundo.

Com exceção dos refugiados da Síria e Ucrânia, é desta mesma região que foge a maioria dos refugiados do mundo. A violência no Burundi, os conflitos na República Centro-Africana, no Sudão do Sul, na Nigéria e na República Democrática do Congo contribuíram para aumentar o número de pessoas fugindo ${ }^{52}$. Em termos proporcionais, ou seja, em relação ao número total de habitantes, Jordânia, Líbano e Turquia estão na lista entre os três primeiros países com maior número de refugiados, acompanhados por Nauru, Chade e Sudão do Sul.

De outro lado, quanto às solicitações individuais de refúgio, durante a primeira metade de 2015 foram registrados cerca de um milhão de pessoas, de 190 diferentes nacionalidades, solicitando refúgio em 155 diferentes países. A Alemanha é o primeiro país na lista dentre os que mais registraram novos pedidos de refúgio, com 159.900 solicitações, o maior número desde 1992. A maior parte dos solicitantes fugiram da Albânia, Afeganistão, Iraque, Sérvia e Kosovo e Síria.

\footnotetext{
${ }^{51}$ De acordo com o relatório oficial do ACNUR “Mid Year Trends - June 2015”. (Disponível em http://www.unhcr.org/56701b969.html) (Último acesso em 07/04/2016).

52 São 140.400 refugiados de Burundi reconhecidos "prima facie” na Tanzânia, Ruanda e República Democrática do Congo e 118.800 refugiados do Sudão do Sul acolhidos, no primeiro semestre de 2015, no Sudão, na Etiópia e em Uganda.
} 
São 32.500 pedidos feitos por sírios, contra 12.100 no mesmo período no ano anterior. Outros países na lista dos que mais contabilizam pedidos de refúgio são a Rússia - em razão do conflito na Ucrânia --, Estados Unidos da América, com 78.200 pedidos. Há ainda Hungria, Turquia, África do Sul, Sérvia, Itália, França e Áustria. Os sírios são a primeira nacionalidade dentre os solicitantes de refúgio no mundo.

Avaliando, por outro lado, o impacto econômico da chegada dos refugiados no país de acolhida, a Etiópia está no topo dentre os países mais afetados: são 469 pessoas refugiadas por cada dólar norte-americano. Em seguida, Paquistão, Uganda, República Democrática do Congo, Chade e Quênia. Isso significa que a “crise” dos refugiados é, sobretudo, uma crise para os países mais pobres: crise em termos de densidade populacional e crise em termos de impacto econômico. Mas também crises em termos políticos, culturais, religiosos, etc.

A propósito, a Etiópia vive a pior seca em trinta anos, o que significa, segundo a Organização das Nações Unidas, 400 mil crianças sofrendo de má nutrição aguda e mais de 10 milhões de pessoas carentes de ajuda alimentar ${ }^{53}$. A organização não-governamental “Save the Children” diz que a seca na Etiópia representa uma ameaça tão grande para a vida das crianças quanto a guerra na Síria. Por esta razão, a organização elegeu Síria e Etiópia como prioridades na campanha de arrecadação de fundos.

Para se ter uma boa análise sobre esta crise, é preciso ver exatamente como ela se espalha no mundo. Sobre a população total de refugiados, a Síria é o principal motivo para o brutal aumento de pessoas refugiadas - de 10,4 milhões em 2011 para 15,1 milhões em 2015 (meados) - seguido dos conflitos no Afeganistão, Burundi, República Democrática do Congo, Mali, Somália, Sudão do Sul e Ucrânia ${ }^{54}$. Sem contar os mais de cinco milhões de refugiados palestinos que há décadas vivem nos 58 campos de refugiados organizados pela UNRWA ${ }^{55}$.

\footnotetext{
53 “Ethiopia drought 'as bad for children as Syria's war'. Al Jazeera. Charles Stratford. 17/01/2016. ( Disponível em http://www.aljazeera.com/news/2016/01/ethiopia-drought-prompts-globalappeals-aid-160117143110259.html). (Último acesso em 26/01/2016)”.

${ }^{54}$ No relatório, podemos ver que os países próximos recebem a maior parte das pessoas refugiadas: a Turquia recebeu 1,84 milhões, o Líbano, 1,2 milhões, a Jordânia, 628.800 e o Iraque, com 251.330, seguido do Egito, com 131.900. E ficamos sabendo que, somente naquele ano, 839.000 pessoas tiveram que atravessar fronteiras em busca de proteção. Outras crises incluem República Democrática do Congo, de onde saíram 535.330 pessoas (sem contar os 2,7 milhões de deslocados internos), República Centro-Africana, contabilizando 470.600 pessoas, Miamar, com 458.400, Eritreia, com 383.900 e Iraque, com 377.700. O recente conflito no Sudão do Sul
} 
Apesar de tudo, a verdade é que a grande maioria das pessoas que fugiu de suas casas buscou proteção dentro do próprio país. O principal efeito dos conflitos e perseguições é o deslocamento interno. São 32.2 milhões de pessoas até meados de 2015, sendo que pelo menos 4.2 milhões se deslocaram apenas neste período ${ }^{56}$. Isso significa que a maior parte das pessoas que deixaram suas casas ainda vive nos países em conflito ou onde sofreram perseguições. Exatamente o dobro do número de pessoas oficialmente refugiadas.

Depois dos deslocados internos, o maior grupo de refugiados é composto por pessoas que buscaram proteção nos países de fronteira. Quanto a estes, em geral eles foram reconhecidos "prima facie”, o que significa que não passaram por um sistema individualizado de reconhecimento, mas, em vez disso, foram registrados como refugiados, morando em tendas nos campos ou distribuídos em cidades mais afastadas, enquanto que uma parte menor participava da vida nas cidades principais.

Como argumenta Fassin, para que este duplo registro do humanismo possa funcionar, impedindo que os refugiados dos campos (no sul) possam reivindicar as prerrogativas como solicitantes de refúgio (no norte), as fronteiras morais e territoriais entre os dois mundos devem estar seladas tão firmemente quanto possível (2012, p. 253). E, acrescentaríamos, a retórica do humanitarismo, de um lado, e o apelo às razões de estado, de outro, dão condições para se formalizar institucionalmente e juridicamente a vedação entre estas duas partes do mundo.

Entre estas fronteiras - que separam e ligam os refugiados do campo e os solicitantes de refúgio nas cidades - é sempre a arbitrariedade que funciona e sempre legitimada pela exceção das crises e pela escassez de recursos. O campo de refugiados é uma das imagens mais emblemáticas da exceção e da arbitrariedade como expressões da governabilidade. No entanto, a operação

transformou a vida nos países da região próxima, que já enfrentam suas próprias crises: 275.400 pessoas para Etiópia, 190.700 para o Sudão e 179.600 para Uganda.

${ }^{55}$ Sigla para United Nations Relief and Works Agency for Palestine Refugees in the Near East ou, em português, Agência das Nações Unidas de Assistência aos Refugiados da Palestina no Oriente Próximo.

${ }^{56} \mathrm{O}$ maior número de novos deslocados está registrado no Iêmen, com 933.500, seguido por Ucrânia (559.000) e República Democrática do Congo (558.000), Nigéria (378.500), Iraque (36.500) e Paquistão (309.200). Em termos absolutos, a Síria contabiliza o maior número de deslocados internos, com 7,6 milhões de pessoas e, em seguida, Colômbia, com 6,5 milhões, Iraque (4 milhões), Sudão (2,3 milhões), Paquistão (1,6 milhões), Sudão do Sul (1,5 milhões), República Democrática do Congo (1,5 milhões), Nigéria (1,4 milhões) e Ucrânia (1,4 milhões). 
incessante de transformar solicitantes de refúgio em "migrantes ilegais” através da recusa aos seus pedidos é o outro lado da mesma moeda.

Neste sentido, o refugiado e o campo podem ser as figuras paradigmáticas de nosso tempo, mas apenas se levamos em consideração o que há entre cada uma das figuras. Entre os deslocados internados, os refugiados dos campos, os solicitantes e os migrantes ilegais, o que há nestes intervalos? Neste sentido, o campo de Dadaab, de um lado, e o campo de Calais, de outro, cada um a seu modo, e igualmente o espaço entre eles, são expressões emblemáticas da "crise dos refugiados" e da "exceção" como expressão do governo biopolítico exercido sobre os sujeitos que fogem. Eis a crise como nome da recomposição do poder. Insistimos, porém, que apelar à imagem ou ao conceito de exceção não pode servir nem para afirmar a totalidade e invencibilidade do poder, nem tampouco para acusar as pequenas rupturas ou crises do sistema. A exceção é o modo de gestão.

\section{2}

\section{Entre Dadaab e Calais: o campo e o vácuo como paradigmas}

Dadaab, oficialmente o maior campo de refugiados do mundo, localizado no Quênia, chegou a abrigar mais de 400 mil pessoas, em sua maioria refugiados da Somália. Em 2015, apesar da determinação do governo do Quênia em desativar o campo, e a despeito dos esforços das organizações humanitárias para repatriação dos refugiados ${ }^{57}$, o campo mantinha seu trágico posto.

De outro lado, há Calais, ou melhor, “Calais Jungle”, ou apenas “Jungle” (“Selva”) ${ }^{58}$. A “Selva” é o nome ou apelido dado ao acampamento montado por refugiados que tentam passar da cidade francesa de Calais para o Reino Unido, através do porto ou pelo Eurotúnel. Não é um campo de refugiados no sentido estrito do termo e nem sequer tem um lugar fixo, já que as pessoas movimentam-

\footnotetext{
57 Notícias sobre o fechamento do campo estão disponíveis em http://www.unhcr.org/pages/49e483a16.html (Último acesso em 16/01/2016).

58 Além da "Selva” (“Jungle”) de Calais, o acampamento de Grande-Synth, próximo a Dunkirk, na França, se tornou também abrigo provisório e precário para cerca de 2.500 pessoas que buscam refúgio. As condições em que vivem seus habitantes, incluindo crianças pequenas e mulheres é, segundo diversos relatos, ainda pior do que em Calais. Há apenas duas estações de água potável e 26 banheiros químicos.
} 
se de um lugar para outro - o que inclui a ocupação de prédios abandonados -- à medida que as autoridades francesas os pressionam ${ }^{59}$.

Dadaab - um complexo composto por cinco campos - é apenas o maior dentre os vários campos do mundo. Com mais de vinte anos de existência, recebeu a maior parte dos somalianos que fugiram da guerra civil conflagrada em 1991 e também pessoas que fugiram das consequências das disputas de grupos pelo poder, da seca e da fome ${ }^{60}$.

Com cem quilômetros de extensão, e mais de duas décadas de existência, o conjunto de campos situado na cidade semiárida de Dadaab abrigava, em 2015, 329.811 pessoas. Começaram a ser construídos em 1992 e o número de habitantes variou durante os anos, alcançando seu maior número em 2011, com aproximadamente 500 mil pessoas ${ }^{61}$. Os campos, criados para abrigar 90 mil pessoas, chegaram a receber mais de mil por dia, fugindo não apenas dos efeitos imediatos da violência, mas também das consequências da seca. Cerca de um quarto dos habitantes eram, em 2011, pessoas que fugiam da seca e da fome. Muitos chegavam a Dadaab em situação de severa desnutrição ${ }^{62}$.

A maioria fugiu da guerra civil na Somália, incluindo diferentes grupos étnicos minoritários. Cerca de 80\% dos habitantes do campo, em 2015, era composto por mulheres e crianças, incluindo as nascidas no próprio campo. A propósito, muitos dos habitantes passaram toda sua vida dentro dos campos e muitos relatam que não se sentiam ligados a nenhuma das nacionalidades, nem

59 "La 'jungle" de Calais est majoritairement située en zone Seveso". (Disponível em http://www.lemonde.fr/societe/article/2015/10/19/la-jungle-de-calais-est-majoritairement-situeeen-zone-seveso_4792559_3224.html.) "What is Britain doing to help the Calais migrant crisis?” (Disponível em http://www.france24.com/en/20151021-france-cazeneuve-calais-jungle-britainrole-resolving-refugee-migrant-crisis). (último acesso em 17/01/2016).

${ }^{60}$ Além dele, há o complexo de Dollo Ado, na Etiópia, com quase 300 mil pessoas, a maioria somalis; Kakukma, no Quênia, com mais de 120 mil, entre somalis e sudaneses; Al Zaatri, na Jordânia, que chegou a receber cerca de 5 mil refugiados sírios por dia, com número total variando entre 70 a 150 mil; Jabalia, na Faixa de Gaza, com 110 mil palestinos; Mbera, na Mauritânia, com cerca de 75 mil pessoas fugindo dos conflitos no Mali; Yida, no Sudão do Sul, com 70 mil; Nakivale, em Uganda, que mantinha 68 mil ruandeses refugiados; Nyaragusu, na Tanzânia, com mais de 68 mil pessoas, a maioria de Burundi e República Democrática do Congo; e, finalmente, em Tamil Nadu, na India, onde vivem cerca de 66 mil pessoas que fugiram do Sri Lanka ${ }^{60}$."Ten largest refugees camp”. Wall Street Journal. 06/09/2013. (Disponível em http://www.wsj.com/articles/SB10001424127887323932604579052742703621858) (último acesso em 16/01/2016).

61 "Inside world's biggest refugee camp". Blogs.aljazeera.net. July 8, 2011. (último acesso em 16/01/2016).

62 "Kenya: Fleeing Somalis Struggle To Find Shelter At The World's Largest Refugee Camp". MSF USA. Retrieved2015-10-19. (último acesso em 16/01/2016). 
somalis nem quenianos ${ }^{63}$. A eles posteriormente se juntaram refugiados do Sudão, República Democrática do Congo, Etiópia, Uganda e Ruanda.

Como uma grande cidade, os campos de Dadaab contam com densa atividade econômica, hospitais, escolas, espaços religiosos, estações de polícia, estações de ônibus e ligas de futebol ${ }^{64}$. Organizados e gerenciados pelo ACNUR, os campos contavam com a contribuição de outras organizações, como Médico Sem Fronteiras e Cruz Vermelha, dentre outras, que atuam para melhorar as condições dos campos, resolvendo problemas de desnutrição, saúde frágil, insegurança e outros. Em média, cada tenda abrigava quatro pessoas, que além de necessidades básicas, enfrentavam problemas de acesso a educação e trabalho. O direito a trabalhar é negado aos habitantes dos campos. Há relatos de garotas envolvidas em prostituição como forma de melhorar a subsistência de suas famílias ${ }^{65}$.

Os habitantes dos campos não são protegidos pelo governo do Quênia e, portanto, não estão identificados como cidadãos daquele país. Em razão disso, são constantes os casos de prisão, agravando os estigmas que recaem normalmente sobre os refugiados em geral e em especial os que habitam os campos. Além disso, são acusados de causarem prejuízos à economia do país, ainda que alguns estudos demonstrem que eles são economicamente autossuficientes ${ }^{66}$.

Em 2013, os governos da Somália e Quênia assinaram um acordo, com intervenção do ACNUR, para a repatriação voluntária dos habitantes somalis dos campos. O acordo foi uma resposta imediata aos ataques em Westgate, em Nairóbi, creditados ao grupo al-Shabaab, que supostamente recrutava parte de seus membros em Dadaab ${ }^{67}$. No entanto, não há quaisquer evidências de que isso seja verdade $^{68}$. O ataque a um centro comercial resultou na morte de 67 pessoas,

63 "No Direction Home: A Generation Shaped by Life in Dadaab". UNFPA - United Nations Population Fund. Retrieved 2015-11-23. (Último acesso em 16/01/2016).

64 “Inside Dadaab, the 'strange parallel universe' of the world's largest refugee camp”. Richard Warnica. Disponível em [http://news.nationalpost.com/arts/books/inside-dadaab-the-strangeparallel-universe-of-the-worlds-largest-refugee-camp]. (Último acesso em 16/01/2016).

65 "Refugee Reports November 2002" (PDF). Refugees.org(Último acesso em 16/01/2016).

${ }^{66}$ Montclos, Marc-Antoine Perouse De; Kagwanja, Peter Mwangi (2000-06-01). "Refugee Camps or Cities? The Socio-economic Dynamics of the Dadaab and Kakuma Camps in Northern Kenya". Journal of Refugee Studies 13 (2): 205-222.doi:10.1093/jrs/13.2.205. ISSN 0951-6328.

67 "Kenya loses patience over Dadaab refugee camp housing displaced Somalis". hiiraan.com. Retrieved 2015-11-02. (Último acesso em 16/01/2016).

68 "Climate of fear in Dadaab refugee camp leads many to consider repatriation". Mélanie Gouby .The Guardian. 20/05/2015. (Disponível em http://www.theguardian.com/global- 
com 175 feridos $^{69}$. A despeito do acordo, a maioria voltou por conta própria. Em fevereiro de 2014, cerca de 100 mil pessoas voltaram à Somália ${ }^{70}$.

Depois do atentado na Universidade Garissa, em abril de 2015, que resultou na morte de 148 pessoas, o governo do Quênia solicitou ao ACNUR repatriação dos refugiados no prazo de três meses para regiões consideradas seguras na Somália. Novamente, especulava-se que habitantes dos campos estivessem sendo recrutados pelo grupo al-Shabaab. O ultimato, porém, terminou sem que a repatriação se concluísse ${ }^{71}$. De acordo com organizações internacionais de direitos humanos, como a Human Rights Watch, não há segurança adequada para os refugiados que serão repatriados, e, portanto, forçar o retorno fere a Convenção de $1951^{72}$.

Calais é o maior e mais movimentado porto operando entre o Reino Unido e noroeste da Europa. Ela tem tanto um porto da balsa e da Eurotúnel, e, portanto, comporta uma enorme quantidade de tráfego e embarcações. Isso também torna o lugar mais movimentado para as pessoas que pretendem arriscar-se na travessia. Na região de Calais, nasceu o acampamento chamado "Calais Jungle”, ou simplesmente "Jungle”. O acampamento começou com um centro de acolhimento montado pela Cruz Vermelha, chamado Sangatte, em 1999. Rapidamente, o centro ficou superlotado e os migrantes e refugiados passaram a ocupar a região em torno do porto, assim que Sangatte foi fechado, em novembro de 2002, por determinação do então Ministro do Interior, François Sarkozy.

O governo francês enfrenta o dilema entre atender as necessidades humanitárias dos refugiados e migrantes em Calais, sem atrair mais pessoas, cumprindo, assim, o compromisso assinado em 2003 (Tratado de Touquet ${ }^{73}$ ), de

development/2015/may/20/dadaab-refugee-camp-kenya-repatriation-somalia). (Último acesso em 16/01/2016).

${ }^{69}$ Associated Press; Daniel, Douglass K. (21 September 2013). "39 people killed in Kenya mall attack claimed by Somali militants; hostages still held". The Washington Post. p. 2. Retrieved 21 September 2013.(Último acesso em 16/01/2016).

70 "Kenya softens its position on proposed closure of Dadaab refugee camp". Goobjoog. 30 April 2015. Retrieved 11 May 2015. (Último acesso em 16/01/2016).

71 "The future of the world's largest refugee camp". ISS Peace and Security Council Report. 24 August 2015. Retrieved4 September 2015. (Último acesso em 16/01/2016).

72 "Dadaab refugee camp clousure would risk 350,000 Somali lives, warns Amnesty". The Guardian. Sam Jones. 17/04/2015. Disponível em http://www.theguardian.com/globaldevelopment/2015/apr/17/dadaab-refugee-camp-closure-risk-350000-somali-lives-amnesty

(Último acesso em 16/01/2016).

${ }^{73}$ Em 4 de fevereiro de 2003, os governos do Reino Unido e França firmaram o Tratado de Touquet, -- formalmente denominado "Tratado entre o Governo do Reino Unido e o Governo da 
impedir a imigração ilegal para o Reino Unido. O principal resultado do Tratado Le Touquet é a criação de um gargalo na cidade de Calais.

Houve várias intervenções por parte das autoridades francesas para fechar o acampamento, desde então. Em 2009, centenas de pessoas foram presas e as tendas foram destruídas por tratores. Os migrantes e refugiados, no entanto, retornaram à "Selva” e continuaram enfrentando repressão. Em 2014, havia cerca de 1300 pessoas no acampamento, com destaque para nacionais de Eritréia, Somália e Síria ${ }^{74}$. Em 2015, as estimativas calculavam 6 mil pessoas vivendo na "Selva"75.

A maior parte dos habitantes do campo são homens jovens, provenientes de países atingidos por conflitos, que pretendem entrar no Reino Unido onde, supostamente, as condições econômicas e o mercado de trabalho são melhores do que na França. Devido ao rigor da legislação britânica ou à seletividade do serviço de imigração, é quase impossível para alguém sem dinheiro e razões justificadas, entrar no país. Só é possível requerer refúgio (ou asilo) dentro do território britânico, o que explica porque os candidatos a refúgio e migrantes tentem entrar clandestinamente no país, arriscando sua própria vida.

Muitos deles pagaram contrabandistas, gastando cerca de três mil dólares para chegar a Calais através do mar. Alguns deles fizeram dezenas de tentativas de travessia até o Reino Unido, sem sucesso. Recentemente, algumas dezenas foram flagradas tentando a travessia a bordo de caminhões de carga ${ }^{76}$. O próprio acampamento, em si, traz grandes riscos, especialmente para mulheres. Entre os habitantes da "Selva”, porém, há muitos que não pretendem atravessar para o Reino Unido, mas permanecem em Calais devido à inadequação da França no fornecimento de habitação e apoio para aqueles que solicitam asilo.

Pelo menos 15 pessoas morreram em Calais, durante o ano de 2014, tentando a extremamente arriscada travessia até o Reino Unido, incluindo crianças

República Francesa relativo à execução de controles fronteiriços em portos marítimos de ambos os países sobre o Canal da Mancha e do Mar do Norte” - que determina o estabelecimento de controle migratório em ambos os países, como forma de barrar a imigração denominada "ilegal" ou "indesejada".

74 "Calais mayor threatens to block port if UK fails to help deal with migrants". Natacha Bouchart, The Guardian, 3/09/14. Retrieved 1 July 2015.(Último acesso em 17/01/2016)

75 "Calais crisis: Bicycle repair shops, mosques and an Orthodox church - the town where migrants wait to cross to Britain”. Rory Mulholland, The Telegraph, 5/07/2015. Retrieved 22 July 2015. (Último acesso em 17/01/2016).

76 “'At night it's like a horror movie' - inside Calais's official shantytown". Angelique Chrisafis, The Guardian, 6/04/ 2015. (Último acesso em 17/01/2016). 
e mulheres. Em 2015, foram pelo menos $10^{77}$, segundo dados oficiais, mas há fontes que contabilizaram pelo menos 24 vítimas, principalmente jovens abaixo dos 25 anos de idade ${ }^{78}$. E quanto maior o número de pessoas chegando, tornam-se ainda mais constantes as tentativas e os riscos, assim como os conflitos com as autoridades policiais. Alguns deles foram enterrados em sepulturas sem identificação. Os migrantes e refugiados que vivem na "Selva” enfrentam duras condições de sobrevivência, incluindo falta de higiene, frio e fome.

O representante do escritório do ACNUR na Europa descreveu a situação em Calais como "vergonhosa” e incoerente “com os valores que uma sociedade democrática deve ter”. Ele comparou a situação em Calais com os campos de refugiados na Turquia, para onde fogem milhares de pessoas escapando da guerra na Síria. Há relatos que traficantes cobram entre 800 a 2.500 libras para fazer a travessia dos refugiados e migrantes. E há também registros de mulheres que foram sexualmente exploradas por traficantes, em troca de ajuda na travessia para o Reino Unido ${ }^{79}$

Não há regulamentos, nenhuma autoridade civil, ou intervenção estatal na “Selva”, a não ser repressão policial, que espera pelos tumultos para agir. As pessoas não tem nada para fazer, exceto esperar por uma oportunidade de fugir e, enquanto isso, lidar com a miséria e com suas necessidades mais básicas. Nas ruas, cheias de lama e poças de água, homens ficam em roda, como se esperassem por algo. Carrocerias de caminhões servem como sanitários improvisados e há excrementos humanos espalhados pelos poucos arbustos que ainda restam, fazendo a vida dos moradores ainda mais insuportável. Há poucas crianças e as mulheres correspondem, segundo estimativas não oficiais, a $10 \%$ do total dos habitantes. Não há registros oficiais, nenhuma contabilidade, nada sobre as pessoas que estão lá. Mesmo assim, os habitantes conseguiram construir pequenos estabelecimentos, como bares, restaurantes, biblioteca, igreja, mesquita e até um banho turco.

77 "Calais Migrant Crisis Is 'Civil Emergency': U.N.". Newsweek. Lucy Westcot. 21/08/ 2015.(Último acesso em 16/01/2016).

78 Informação disponível no site "Calais Solidarity". (Disponível em https://calaismigrantsolidarity.wordpress.com/deaths-at-the-calais-border). (Último acesso em 16/01/2016).

79 “At least 15 migrants died in 'shameful' Calais conditions in 2014”. The Guardian. Matthew Taylor e Guy Grandjean. 23/12/2014. (Disponível em http://www.theguardian.com/uknews/2014/dec/23/15-migrants-trying-enter-uk-die-shameful-calais-conditions). (Último acesso em 17/01/2016). 
A violência é usual para os habitantes do acampamento. Há relatos de espancamentos, agressões e humilhação por parte de policiais, incluindo uso de por spray de pimenta, gás e outros meios “não letais” de repressão ou tortura. A ameaça de grupos fascistas também é uma realidade enfrentada em Calais. Em 2013, surgiu um grupo fascista organizado, chamado “Sauvons Calais” (Salve Calais). Eles realizaram encontros entre diversos grupos de extrema-direita, incluindo a organização de um ataque, em março de 2014, contra os habitantes do acampamento, com uso de coquetéis molotov.

Ataques e ofensas racistas são constantes e os migrantes e refugiados relatam grande sensação de insegurança quando estão sozinhos. Ameaças feitas por pessoas armadas, em carros ou em motos são comuns, e outros incidentes de vandalismo contra instalações dos habitantes do acampamento foram também registrados. Muitas pessoas e empresas contribuem para o estabelecimento de regime de apartheid em Calais: algumas lojas, bares e cafés não permitem a entrada dos migrantes e refugiados, especialmente se são negros. O tratamento nos serviços públicos também é discriminatório, principalmente para as mulheres que precisam de apoio.

Novas linhas de cercas de arame farpado foram montadas e muros se tornaram mais altos. Esta foi a contribuição do governo britânico. Toda ajuda vem de doações e do trabalho dos voluntários, que são muitos, levando cobertores, tendas, água, materiais de construção, roupas e alimentos. E até mesmo espetáculos de teatro.

\section{3}

\section{Os campos na fronteira: nem dentro, nem fora da lei}

O ponto mais interessante sobre o campo de Calais talvez seja seu lugar em relação à lei: não existe oficialmente como campo, mas é tolerado pelo governo. Inúmeras organizações não-governamentais, além de voluntários de várias partes do mundo estiveram em Calais para amparar os refugiados, sem qualquer contrapartida por parte do governo francês. Assim é também a situação dos sujeitos que vivem na "Selva”. Normalmente, seriam deportados ou detidos na condição de migrantes “ilegais”. No entanto, a polícia intervém apenas para 
controlar pequenas irrupções de desordem, para garantir que não atravessem o túnel ou, finalmente, para despeja-los.

Antes de Calais, porém, houve Sangatte. E décadas antes de Sangatte, aquela mesma região abrigou um campo nazista de trabalhos forçados, organizado pela “Organização Todt” ${ }^{80}$. Desde 1999, a região que depois se tornaria conhecida pelo nome de "Selva de Calais” já era uma “selva”. Naquele tempo, contudo, se chamava Sangatte e era ocupada por antigos hangares que acomodaram as máquinas que antes foram usadas para abrir o túnel entre França e Reino Unido. Ponto de parada para os refugiados que pretendiam chegar ao Reino Unido, naqueles anos cerca de 55 mil pessoas encontraram abrigo temporário em Sangatte, amparados pela Cruz Vermelha (Fassin, 2012, p. 133).

Em sua inauguração como abrigo a refugiados, 200 pessoas conseguiram abrigo e a elas logo se seguiram, nos dois anos seguintes, mais de mil pessoas. Em várias ocasiões o campo foi ameaçado de fechar, ora por razões de "segurança”, ora em nome da "república” (Fassin, 2012, p.134). Mas antes destes primeiros refugiados, aquela mesma região foi ocupada, nos anos 1980, por paquistaneses e vietnamitas que pretendiam fazer a travessia. Na década seguinte, chegaram também pessoas do leste europeu e de Sri Lanka, fugindo, os primeiros, do colapso do comunismo e, os segundos, da guerra civil. E posteriormente, ainda vieram os refugiados de Kosovo, fugindo da perseguição na Sérvia.

O Reino Unido recusou a entrada a eles, que foram então devolvidos à França. E então começaram pequenas iniciativas para amparar aquelas pessoas que se viram obrigadas a dormir nas ruas e parques da região de Calais. Em 1989, diante do relevante fluxo de pessoas fugindo do Kosovo - e diante da gravidade e publicidade da perseguição - as autoridades locais tiveram que assumir a existência do campo, ainda que como um abrigo noturno. E em pouco tempo, chegaram os afegãos e os curdos que fugiam de perseguição.

\footnotetext{
${ }^{80}$ A Organização Todt foi um grupo de engenharia civil e militar do Terceiro Reich na Alemanha, que ganhou o nome de seu fundador, Fritz Todt, engenheiro e eminente figura nazista. A organização foi responsável por uma enorme gama de projetos de engenharia, especialmente no período antecedente à Segunda Guerra e durante. A organização foi responsável por várias obras dentro da Alemanha, mas também na França ocupada e na União Soviética durante a guerra. Tornou-se famosa por usar trabalho forçado. (DELMAIRE, Danielle."Les camps de juifs dans le nord de la France" in "Orients. Bulletin de l'association des anciens élèves et amis des langues orientales”. Mai 2008. (Disponível em http://anciens.inalco.free.fr/Orients/200805.pdf) (Último acesso em 10/04/2016).
} 
Sangatte tornou-se então o lugar onde habitavam os indivíduos que não poderiam ser tolerados - por serem imigrantes ilegais - mas que não poderiam ser punidos, nem devolvidos - porque fugiam de perseguição e, portanto, eram refugiados. Um duplo registro, utilizado conforme a conveniência, mas que revelava o lugar intermediário que os refugiados de fato ocupavam: o lugar da exceção e da arbitrariedade.

Lugar também da convergência de diferentes presenças: organizações humanitárias, como a Cruz Vermelha, dentre outras, além de coletivos e grupos espontâneos, voluntários e, por fim, o estado, através da polícia francesa. Enquanto as organizações e voluntários pudessem controlar os refugiados e manter a ordem, os policiais se mantinham a distância. Paradoxalmente, era um dos poucos lugares no país onde um “migrante ilegal” poderia ficar em segurança, sem ser importunado por policiais.

Nomeado ora como "selva", lugar de parada, acampamento ou campo, Sangatte ou Calais poderia ser identificado como lugar da exceção, especialmente pelo que existe no suposto vácuo entre cada um destes lugares e, em especial, pelo modo como se relacionam. Mesmo sem os arames farpados, muros e mesmo livre para entrada e saída dos refugiados, ainda assim pode ser considerado um campo. Contudo, é importante, desde já, insistir nas ambivalências da exceção e perceber os vácuos também como brechas e recusar o campo como totalidade do poder sem resistência.

Fassin argumenta que Sangatte não era exatamente um campo, porque era uma área aberta e os refugiados eram livres para entrar e sair, mas, ao mesmo tempo, era um espaço com a mesma estrutura e organização que caracteriza um campo de refugiados: desde o número de pessoas dependendo de ajuda externa, sua condição de fato (como refugiados), a presença de pessoas para assistência e controle, procedimentos de organização, dentre outras características (Fassin, 2012, p. 151).

Tudo fica ainda mais sombrio, entretanto, quando se sabe que no passado este mesmo território onde se ergueram Calais e Sangatte era antes um campo nazista de trabalho forçado. Oficialmente era chamado de "campo de trânsito" durante a Segunda Guerra, onde os judeus ficavam antes de serem enviados ao campo de extermínio. Em 1942, naquele mesmo terreno, cerca de três mil judeus - franceses e belgas, sobretudo -- foram forçados a trabalhar na construção do 
muro do Atlântico antes de serem levados a Auschwitz. Uma pequena pesquisa com os moradores da região revelou que a memória sobre o campo nazista aparentemente se apagou ${ }^{81}$.

Mais do que decidir se Sangatte ou Calais é um campo ou não, Fassin se interessa por encontrar os elementos que caracterizam o campo e, para tanto, recorre à tese de Agamben sobre o campo: não como um fato histórico ou como anomalia pertencente ao passado, mas como a matriz ou "nomos" da exceção, como espaço político que subsiste como possibilidade e fato. Onde a exceção se torna a regra.

\section{4}

\section{O "campo" de Brasiléia: a solução humanitária para os haitianos}

Até recentemente, o Brasil tinha seu “campo de refugiados”, na pequena cidade de Brasileia, no Acre, região norte do país. Mais de 20 mil migrantes principalmente haitianos, mas também senegaleses, nigerianos, dominicanos e pessoas de outras nacionalidades -- passaram pelo abrigo de Brasileia durante seus poucos anos de funcionamento. O abrigo, construído para abrigar 300 pessoas, chegou a comportar mais 2.500, que dividiam dez banheiros e oito chuveiros. Sem contar com itens básicos, como sabão ou creme dental, e vivendo junto ao esgoto que corria a céu aberto, 90\% dos habitantes do “campo” passaram por hospitais em razão de diarreia ${ }^{82}$.

O fluxo de haitianos começou em 2010, imediatamente após o terremoto que atingiu o Haiti, causando a morte de mais de 300 mil pessoas e o mesmo número de pessoas deslocadas. Todos os hospitais foram destruídos ou severamente danificados, assim como o principal presídio do país, o Palácio Presidencial, o edifício do Parlamento e a sede da Missão das Nações Unidas para estabilização no Haiti (MINUSTAH) ${ }^{83}$. Se antes a presença de haitianos era

${ }^{81}$ BERNARDOT, Marc, \& DEGUINES, Isabelle. “Cohabiter à Sangatte”. Plein droit 3/2003 (nº 58) , p. 25-28 (Disponível em www.cairn.info/revue-plein-droit-2003-3-page-25.htm) (Último acesso em 10/04/2016).

82 Disponível no site da organização não-governamental Conectas (http://www.conectas.org/pt/acoes/politica-externa/noticia/17008-governo-fecha-abrigo-parahaitianos-em-brasileia) (Último acesso em 13/04/2016).

83 FOURNIER, Keith. "Devastating 7.0 Earthquake Hammers Beleagured Island Nation of Haiti". Catholic Online. 13/01/2010. (Disponível em 
inexpressiva -- até 2010, eram 36 pessoas $^{84}$-- entre 80 a 130 mil haitianos ${ }^{85}$ passaram pelas cidades de Epitaciolândia e Brasileia, no Acre, desde que iniciou o fluxo migratório. Destes, pelo menos 44 mil estão documentados ${ }^{86}$. A presença do Brasil no comando da MINUSTAH é apontada como o principal motivo para o fluxo migratório para o Brasil, ao mesmo tempo em que aumentaram os obstáculos para entrar nos tradicionais destinos da diáspora haitiana, com República Dominicana, Estados Unidos da América e França.

Antes que o governo brasileiro estabelecesse medidas para facilitar o visto para a chegada dos haitianos, eles eram obrigados a fazer uma rota que incluía República Dominicana, Panamá e Equador, de onde seguiam até Puerto Maldonado, no Peru e então atravessava a fronteira, chegando ao Acre. A rota “ilegal” custava, para cada haitiano, entre 3 a 5 mil dólares, pagos aos agenciadores $^{87}$, o que não impedia que fossem vítimas de vários tipos de precariedade e violência, incluindo sequestros, extorsões e estupros, mas também achaques por parte de policiais de fronteira, pagamento de "coiotes" e perda de dinheiro durante o câmbio clandestino de moeda ${ }^{88}$. A violência a qual eram submetidas os haitianos era imediatamente decorrente de sua situação de “ilegais" e sua condição de "ilegais" era consequência da impossibilidade, para a maioria deles, em atender a todas as exigências para obter um visto de entrada.

http://www.catholic.org/news/international/americas/story.php?id=35181) e "Quake 'levels Haiti presidential palace"'. Sydney Morning Herald. 13/10/2013. (Diponível em http://www.smh.com.au//breaking-news-world/hundreds-feared-dead-in-haiti-earthquake20100113-m5d3.html).

${ }^{84}$ ARAUJO, Adriano A.A. "Reve de Brezil: A inserção de um grupo de imigrantes haitianos em Santo André, São Paulo” - Brasil. Santo André: Dissertação de Mestrado. Programa de PósGraduação em Ciências Humanas e Sociais - UFABC, 2015.

${ }^{85}$ Não há qualquer registro oficial e confiável sobre os números. Pesquisadores e militantes que trabalham com o tema da migração haitiana estimam que o número seja entre 80 a 130 mil migrantes haitianos. Mas nem é possível assegurar que todos eles pretendiam se estabelecer no país ou se o Brasil era parte de uma rota para outros países.

${ }^{86}$ Informação disponível no "Portal Brasil", site do governo brasileiro (http://www.brasil.gov.br/cidadania-e-justica/2015/11/brasil-autoriza-visto-de-residencia-

permanente-para-43-8-mil-haitianos) (Último acesso em 14/04/2016). E há informações, não oficiais, de que um número semelhante de haitianos também já havia sido regularizado.

87 "Número de haitianos que entram no Brasil pelo Acre cai 96\% em 12 meses". G1. Caio Fulgêncio. 08/01/2016. (Disponível em http://g1.globo.com/ac/acre/noticia/2016/01/n-dehaitianos-que-entram-no-brasil-pelo-acre-cai-96-em-12-meses.html) (Último acesso em 18/01/2016).

88 "Instituições fazem mapeamento das rotas de imigração haitiano ao Brasil”. EBC, 15/04/2013. (Disponível em http://www.ebc.com.br/noticias/brasil/2013/04/instituicoes-fazem-mapeamentodas-rotas-de-imigracao-haitiana-ao-brasil) (Último acesso em 13/04/2016). 
Para cruzar a fronteira, os haitianos apelaram ao refúgio, impedindo, deste modo, que fossem impedidos de entrar. Identificados como solicitantes de refúgio, os haitianos estavam regularizados e conseguiam documento para trabalhar. Em resposta ao crescente fluxo, o governo brasileiro decidiu regularizar os haitianos com documentos de permanência, utilizando uma resolução do Conselho Nacional de Imigração (Resolução 27/98) para “casos omissos”. A Resolução 27 é normalmente utilizada para casos que demandam uma solução "humanitária”, especialmente quando o solicitante não pode ser amparado pelo instituto do refúgio. Em determinados casos, Comitê Nacional para os Refugiados "encaminhe" o caso para o CNIG recomendando a regularização por "razões humanitárias”. Esta foi a solução encontrada para os haitianos, desde que o governo brasileiro decidiu que eles não poderiam ser reconhecidos como refugiados.

Os haitianos continuaram chegando e as denúncias de violência e extorsão apenas aumentavam. No início de 2012, uma resolução normativa do Conselho Nacional de Imigração (CNIG) estabeleceu uma cota de 1200 vistos anuais para os haitianos, como forma de regularizar o fluxo migratório e impedir a ação dos “coiotes” e exploradores. A medida temporária foi renovada nos anos seguintes, com ampliação da cota e segue valendo até $2016^{89}$. Além de Porto Príncipe, capital do país, os haitianos conseguiram vistos em Quito (Equador) e Lima (Peru). Isso fez cair a chegada irregular em 96\%. De acordo com o Ministério das Relações Exteriores, a emissão de vistos para os haitianos aumentou em 1537\% entre 2012 e $2015 .^{90}$ Em vez de Acre, os haitianos tem ido para as grandes capitais, como Rio de Janeiro e São Paulo.

Em abril de 2013, em razão do aumento expressivo do fluxo, o governo do Acre decretou situação de "emergência social” em Epitaciolândia e Brasileia. Em 2014, com as enchentes do Rio Madeira, o abrigo teve que ser desativado ${ }^{91}$. Um

\footnotetext{
${ }^{89}$ Informação disponível no site do Instituto de Migração e Direitos Humanos (IMDH), dirigido pela advogada e religiosa Rosita Milesi (Disponível em http://www.migrante.org.br/index.php/migracao-haitiana2/266-noticia-visto-humanitario-aosimigrantes-haitianos-e-prorrogado-ate-2016) (Último acesso em 13/04/2016).

90 "Número de haitianos que entram no Brasil pelo Acre cai 96\% em 12 meses". G1. Caio Fulgêncio. 08/01/2016. (Disponível em http://g1.globo.com/ac/acre/noticia/2016/01/n-dehaitianos-que-entram-no-brasil-pelo-acre-cai-96-em-12-meses.html) (Último acesso em 18/01/2016).

${ }^{91}$ Quando a situação no abrigo se tornou crítica, o Secretário de Direitos Humanos do Acre chegou a solicitar ao governo federal o seu fechamento. O Secretário Nilson Mourão sugeriu ao governo
} 
novo abrigo foi improvisado em Rio Branco, capital do Acre. A partir de abril de 2014, o governo do Acre contratou ônibus para levar os haitianos a São Paulo, dando início a uma crise envolvendo o governo de São Paulo e o governo federal $^{92}$. Não se sabe ao certo se a transferência havia sido negociada ou avisada, mas o fato é que cerca de 500 haitianos ${ }^{93}$ foram levados a São Paulo e só conseguiram abrigo improvisado graças às iniciativas da Missão Paz ${ }^{94}$, uma organização humanitária ligada à Pastoral dos Migrantes. E uma vez mais tiveram que enfrentar a provisoriedade e precariedade dos abrigos ${ }^{95}$.

\section{5}

\section{A "crise" dos haitianos, a diáspora e o campo}

A “crise” dos haitianos é um das mais relevantes expressões da ambiguidade e da ambivalência da política migratória e da gestão humanitária no Brasil. É talvez o paradigma central da questão humanitária e da gestão biopolítica dos fluxos migratórios. Primeiro, porque a solução humanitária para os haitianos segue a presença militar brasileira no país, através da Missão das Nações Unidas para a Estabilização no Haiti ${ }^{96}$. Desde sua implementação, há mais de dez anos, a

federal fechar a fronteira do Brasil com o Peru, afirmando: "Estamos à beira de uma tragédia no abrigo, mas o governo decidiu manter a tradição brasileira de manter as fronteiras abertas". O Ministério Público Federal do Acre instaurou uma ação civil pública para exigir do governo brasileiro melhor tratamento aos haitianos. ("Acre quer fechar fronteira para evitar excesso de haitianos no Brasil.” O Globo. 15/01/2014. Disponível em http://oglobo.globo.com/brasil/acrequer-fechar-fronteira-para-evitar-excesso-de-haitianos-no-brasil-11309952. Último acesso em 14/04/2016).

92 “Envio de haitianos a SP escancara crise migratória”. BBC Brasil. 25/04/2015. (Disponível em http://www.bbc.com/portuguese/noticias/2014/04/140425_haitianos_entenda_jf) (Último acesso em 14/04/2016).

93 “Ministério barra envio de haitianos a São Paulo”. Estadão. 19/05/2016 (Disponível em http://sao-paulo.estadao.com.br/noticias/geral,ministerio-barra-envio-de-haitianos-a-saopaulo,1690549) (Último acesso em 14/04/2016).

${ }^{94}$ Fundada por religiosos scalabrinianos, a Missão Paz funciona na paróquia de Nossa Senhora da Paz, no bairro do Glicério, desde 1939. Atende refugiados, solicitantes de refúgio, migrantes internos e migrantes estrangeiros. Informações estão disponíveis no site da Missão Paz (http://www.missaonspaz.org) (Último acesso em 14/04/2016).

95 "Haitianos chegam a SP e vivem em condições precárias em salão de igreja”. O Globo. 20/06/2015. (Disponível em http://oglobo.globo.com/brasil/haitianos-chegam-sp-vivem-emcondicoes-precarias-em-salao-de-igreja-16215248) (Último acesso em 14/04/2016).

${ }^{96}$ Conhecida por MINUSTAH (que, em francês, é a sigla para "Mission des Nations Unies pour la Stabilisation em Haïti) a Missão estabelecida no Haiti é comandada por militares brasileiros desde 2004. Sob a justificativa de levar estabilidade ao país, a Missão já custou mais de R\$ 2 bilhões, dos quais apenas 35\% foram reembolsados pela ONU. Sobre este ponto, consultar "Dez anos no Haiti: a missão militar que ajudou a projetar o Brasil no mundo?” BBC Brasil. Hugo Bachega. 30/05/2014.

(Disponível 
Missão é composta por lideranças militares brasileiras e conta, em grande parte, por tropas brasileiras. A lacuna de paz, de segurança e, portanto, de direitos, é preenchida, por um lado, pela presença militar de um país emergente com ambições no cenário internacional, e, de outro, pela compaixão humanitária na forma de vistos e documentos.

Quanto a isso, a presença brasileira no Haiti suscita muitas contradições, principalmente porque a regulação dos pobres haitianos significa uma via de mão dupla com o governo dos pobres no Brasil. Como diz Cocco (2014, p.43), as forças militares brasileiras desenvolveram um "know how” sobre intervenção em zonas da pobreza urbana, como as favelas, que lhe permitem gerenciar a ordem nas periferias de Cité Soleil, em Porto Príncipe. E, ao mesmo, tempo, a experiência adquirida na intervenção no Haiti é aproveitada na presença militar nas favelas, como na intervenção permanente no Complexo do Alemão, no Rio de Janeiro.

A solução humanitária expõe a ambiguidade da política migratória brasileira: é por uma medida excepcional e improvisada - e, portanto, precária, por mais nobre que sejam suas intenções humanitárias e por mais positivas que sejam seus efeitos, sobretudo no que diz respeito à efetiva documentação dos haitianos - a única possibilidade de garantir os direitos de milhares de pessoas que fogem de uma das maiores catástrofes das últimas décadas. Uma catástrofe, a propósito, que não se resume ao terremoto (com seus 316 mil mortos), nem à extrema pobreza (70\% da população é pobre) ou à instabilidade política (que faz parte da história do país desde o começo do século passado), mas envolve também bloqueio comercial, intervenções militares estrangeiras e uma longa e sangrenta ditadura. "Papa doc”, “Baby doc” e os “Tonton Macoutes”, são alguns dos nomes da violência que se abateu sobre os haitianos.

A outra ambiguidade da solução dada aos haitianos está na forma como a “crise” dos haitianos e a "crise” do Haiti foi percebida e disputada. Primeiro percebidos como vítimas de uma catástrofe natural e, depois, como migrantes econômicos ou migrantes da miséria. Quando a chegada de haitianos passou a ser percebida como um fluxo cuja tendência seria crescer e, sobretudo quando a incapacidade do abrigo (ou "campo”) se tornou um fato, a reação foi apelar à 
retórica de invasão e de crise ${ }^{97}$. E em seguida, a retórica do tráfico e dos “coiotes”.

Na sequência da prisão de um haitiano, acusado como “coiote”, em abril de 2013, o Secretário de Direitos Humanos do Acre afirmara que o Brasil encontrava-se definitivamente na "rota de tráfico" - não apenas de pessoas, mas também de drogas e armas -- e que a migração dos haitianos na América Latina não era algo “espontâneo”, mas forçada por redes de "coiotes”, sem nenhum “controle” por parte do estado. O coordenador do abrigo para migrantes, da mesma Secretaria, acusava o problema de consumo de bebida alcoolica entre os haitianos. Chamados pelo coordenador, agentes da Policia Federal advertiram os migrantes que o uso de bebida alcoolica poderia causar “deportação” ao país de origem $^{98}$.

A criminalização da migração e dos migrantes de um lado e a moralização do outro. A polícia sempre a espreita, como o duplo do governo humanitário. A sua outra face. O mesmo Secretário de Estado, responsável pela pasta de direitos humanos no Acre, expressa sua preocupação com os coiotes e com o tráfico e é ele também que, apelando para a existência de uma crise, solicitou ao governo federal o fechamento da fronteira do Brasil com o Peru ${ }^{99}$.

A ambiguidade está presente em quase todo o percurso e presença dos haitianos no Brasil. A única solução para a crise no abrigo, antes que se decidissem pela transferência dos haitianos - e da crise - para outras partes do país, principalmente São Paulo, eram as empresas que buscavam trabalhadores. Os haitianos logo ficaram conhecidos como bons trabalhadores, procurados

\footnotetext{
${ }^{97}$ Sobre o modo como as mídias trataram o tema dos haitianos, é possível ver a pesquisa publicada no site do Instituto Migração e Direitos Humanos, disponível em http://www.migrante.org.br/images/arquivos/resenha-de-imprensa-2013.pdf (Último acesso em 16/04/2016).

98 “Coiotes cobram US\$ 4 mil”. Circuito Mato Grosso. 07/04/2013. (Disponível em http://www.circuitomt.com.br/editorias/brasil/28086-coiotes-cobram-us-4-mil.html); "Jogador preso seria o primeiro de 'rede de coiotes' no Brasil”. Expresso MT, 06/04/13. (Disponível em http://www.expressomt.com.br/esportes/jogador-preso-seria-o-primeiro-de-rede-de-coiotes-nobrasil-58453.html); e "Haitiano detido no Acre com seis passaportes no sapato". Jornal do Brasil, 09/04/13 (Disponível em http://www.jb.com.br/pais/noticias/2013/04/09/haitiano-e-detido-noacre-com-seis-passaportes-no-sapato/).(Último acesso em 18/01/2016).

${ }^{99}$ Naquela ocasião, o Secretário de Direitos Humanos do Acre afirmou: "Estamos à beira de uma tragédia no abrigo", complementando com o que parecia um complemento à sua queixa: “ mas o governo decidiu manter a tradição brasileira de manter as fronteiras abertas". O Ministério Público Federal do Acre instaurou uma ação civil pública para exigir do governo brasileiro melhor tratamento aos haitianos. ("Acre quer fechar fronteira para evitar excesso de haitianos no Brasil." O Globo. 15/01/2014. Disponível em http://oglobo.globo.com/brasil/acre-quer-fechar-fronteirapara-evitar-excesso-de-haitianos-no-brasil-11309952. Último acesso em 14/04/2016).
} 
ansiosamente por empresários - principalmente da área de construção civil - que diariamente procuravam por corpos aptos ao trabalho duro.

A grossura das canelas e o tamanho do órgão sexual se tornaram critérios para definir a contratação dos homens haitianos: os indícios biopolíticos de um corpo apto para o trabalho pesado. Este procedimento utilizado para a classificação e seleção dos escravos africanos que chegavam ao Brasil no início de sua história moderna teve sua atualização na seleção dos migrantes haitianos que chegaram recentemente na região norte do país ${ }^{100}$.

Se o clássico e ancestral "método" de seleção recebeu reprovação, sobretudo porque a sua perversidade foi tornada explícita, a busca dos trabalhadores dóceis foi e de fato continua sendo comemorada como a boa nova para os pobres migrantes haitianos. A outra dimensão da solução humanitária para os migrantes (ou refugiados) haitianos é a "inserção no mercado de trabalho", ou seja, sua subsistência depende não apenas de seu próprio trabalho, mas de sua submissão aos trabalhos mais explorados, duros e degradantes. Eis o modo de purificar o corpo do migrante que ousou apelar à migração e à ilegalidade da fuga: a redenção pelo trabalho duro.

O caráter escandaloso deste episódio - que chamou a atenção das autoridades e dos jornais como fato isolado - é grave não por sua aparente extemporaneidade. Ao contrário, sua gravidade reside justamente na coerência com os atuais modos de gestão global do trabalho e dos trabalhadores. A descoberta de migrantes bolivianos e chineses trabalhando em regime de escravidão em grandes metrópoles como Rio de Janeiro e São Paulo ${ }^{101}$ - as maiores do país e entre as maiores da América Latina - são outros exemplos.

\footnotetext{
${ }^{100}$ Sobre este fato, há diversas fontes de notícias ("Largura da canela é requisito para haitiano conseguir emprego no Brasil”. G1. 26/05/2016, disponível em http://g1.globo.com/ac/acre/noticia/2015/05/largura-de-canela-e-requisito-para-haitiano-conseguiremprego-no-brasil.html. E há vídeos com depoimentos sobre o "método" de seleção de trabalhadores entre os haitianos (Disponível em https://www.youtube.com/watch?v=hsY9RZlkTwA) (Último acesso em 16/04/2016).

${ }^{101}$ Há inúmeras notícias sobre a descoberta de trabalho escravo ou análogo à escravidão nas grandes cidades brasileiras. Dentre várias fontes, podemos indicar: "http://www.passapalavra.info/2010/11/31342" ， "http://noticias.uol.com.br/cotidiano/ultimasnoticias/2014/05/01/por-trabalho-escravo-mpf-denuncia-4-pessoas-de-confeccao-da-zara.htm” e "http://www.bbc.com/portuguese/noticias/2013/05/130508_trabescravo_estrangeiros_fl.” (Último acesso em 16/04/2016)
} 
Este é o modo de gestão dos fluxos de migrantes e de atribuição e valoração da cidadania. A violência da exploração dos corpos está articulada à precarização da condição jurídica e política destes corpos: gestão biolítica dos fluxos de circulação, trabalho e cidadania. A regularização da situação dos migrantes haitianos, bolivianos e chineses, através de dispositivos jurídicos específicos, certamente diminuem a violência da exploração e o sofrimento das pessoas, mas, ao mesmo tempo, não se mostram como outra coisa que não um momento indispensável à própria sobrevivência dos mecanismos de exploração. 


\title{
A verdade como escassez e raridade
}

\begin{abstract}
"Um carrasco, em nossos dias, é um honrado funcionário; o espírito pragmático da função pública assegura-lhe um bom tratamento. Consequentemente, porque não haveria um carrasco adormecido em todo funcionário honrado? (...) Eles pegam seres vivos capazes de se transformar, e deles fazem matrícula de arquivos, mortos e incapazes da mínima transformação".
\end{abstract}

Franz Kafka ${ }^{102}$

O escritório da Anistia Internacional do Reino Unido publicou, em 2004, um relatório sobre as decisões do governo britânico aos pedidos de refúgio e constatou que uma em cada cinco decisões de recusa foi anulada em recurso ${ }^{103}$. Quase uma década depois, apesar de aparentes melhorias na qualidade da tomada de decisão, o número de recursos deferidos aumentou, com mais de $25 \%$ das decisões anulada em recurso. Estes índices foram observados nos anos de 2010, 2011 e 2012. Na maioria casos, a principal razão para revogar a decisão inicial estava ligada a erros na análise de credibilidade: a decisão estava baseada tão somente em especulações sobre a credibilidade do solicitante, em vez de se fundar em informações objetivas sobre os eventos que determinaram a fuga ou sobre o contexto de violência.

Em 2013, em novo relatório, a Anistia Internacional, em conjunto com a organização "Still Human Still Here", publicou um relatório sobre as decisões do escritório de migração e refúgio do governo britânico, em que se pode ver alguns dos equívocos ou arbitrariedades cometidas pelos julgadores ${ }^{104}$. O relatório

102 JANOUCH, Gustav. Conversas com Kafka. São Paulo: Novo século, 2008.p. 19

103 "Get ir right. How Home Office decision making fails refugees" Amnesty International UK. $\begin{array}{llll}\text { Fevereiro de } 2014 . & \text { (Disponível em }\end{array}$ https://www.amnesty.org.uk/sites/default/files/get_it_right_0.pdf) (Último acesso em 06/05/2016). 104 "A question of credibility: Why so many initial asylm decisions are overtuned on appeal in the UK”. Amnesty International/ Still Human Still Here. Abril 2013. (Disponível em https://www.amnesty.org.uk/sites/default/files/a_question_of_credibility_final_0.pdf) (Último acesso em 06/05/2016). 
analisou também a decisão em grau de recurso, envolvendo cinquenta casos de solicitações de refúgio de pessoas de diferentes países, como Síria, Sri Lanka, Irã e Zimbábue. Em 42 dos 50 casos selecionados aleatoriamente (84\% da amostra), a autoridade responsável pelo julgamento do recurso apontava que a principal razão para a reforma da decisão era o erro na avaliação da credibilidade do caso. Em outras palavras, o julgador de primeira "instância” decidiu que faltava credibilidade ao solicitante e esta foi a principal razão para a recusa.

Os erros no julgamento da credibilidade, segundo o relatório, estão relacionados a "uso de argumentos especulativos”, “análise inadequada das evidências disponíveis”, “utilização de número irrelevante de inconsistências para a recusa” e “utilização inadequada de informações objetivas do país de origem”. Analisando as razões do recurso, também é possível verificar uma série de motivos secundários atacados e que foram importantes na decisão de recusa. A maior parte, também relacionada a questões de credibilidade.

De acordo com o relatório, os critérios para julgamento de credibilidade são utilizados incorretamente, de maneira reiterada, provocando, em muitos casos, um "efeito dominó": a partir de pequenos pontos aparentemente inconsistentes ou implausíveis, o julgador minava todos os demais aspectos do pedido, recusando por inteiro seus argumentos. Além disso, também foram verificados erros em relação a circunstâncias atenuantes e de aplicação correta da lei ("Section 8 of the Asylum and Immigration, Treatment of Claimants, Act $2004^{105}$ ).

Em um dos casos negados, o julgador indeferiu um pedido feito por um solicitante sírio porque ele não foi capaz de responder a perguntas "básicas sobre política internacional” e, portanto, era implausível que ele tivesse tomado parte nos protestos ou “qualquer papel em atividades políticas”. Isso porque o solicitante afirmara que a Turquia, Arábia Saudita e Qatar haviam proposto uma resolução ao Conselho de Segurança das Nações Unidas, em nome das nações árabes, pedindo a renúncia do presidente sírio. Em grau de recurso, o julgador considerou o pouco grau de instrução educacional do solicitante e o fato de que ele morava em área rural como motivos para reformar a decisão, justificando que as informações que ele prestou eram suficientes.

105 Disponível em http://www.legislation.gov.uk/ukpga/2004/19/pdfs/ukpga_20040019_en.pdf (Último acesso em 06/05/2016). 
Em resposta a um pedido feito por solicitante iraniano, o escritório britânico recusou o refugio porque ele, embora tivesse apenas 16 anos de idade ao tempo dos eventos, não fora capaz de dar mais detalhes sobre as atividades que seu falecido pai desenvolvia. Em recurso, o Juiz responsável reformou a decisão e considerou totalmente plausível que um jovem de 16 anos não fosse capaz de explicar com detalhes as atividades em que seu pai estava envolvido. "Não é incomum”, decidiu o Juiz, "que as crianças tenham pouca ou nenhuma compreensão sobre a filiação política de seus pais, sobre os manifestos e a história dos partidos políticos aos quais eram ligados”.

Ao negar o pedido feito por uma solicitante de Sri Lanka, o órgão julgador afirmou que as fotos apresentadas por ela, com cicatrizes resultado de espancamentos, queimaduras com cigarros e de estupro, não serviam de prova, porque não se podia estabelecer que as fotos eram realmente de seu corpo. Em resposta ao recurso, o Juiz britânico acusou a falha do escritório em não considerar outras peças importantes de prova, incluindo as marcas de queimaduras atualmente presentes em seu corpo. Em outro caso, envolvendo um solicitante de Sri Lanka, o Juiz reformou, em recurso, a decisão que recusou refúgio porque ele não fora capaz de lembrar a data de um ataque ocorrido há seis anos. E no caso de um solicitante sírio, o Juiz reformou a decisão que negou refúgio porque ele não sabia detalhes sobre o partido. O juiz, levando em consideração que o solicitante era analfabeto e não tinha posição de destaque no partido, decidiu reconhece-lo refugiado.

Um solicitante da República Democrática do Congo narra que fugiu do país depois ter visto seu pai ser morto a tiros e sua mãe e sua irmã, estupradas. O pedido, no entanto, foi rejeitado porque não pareceu plausível, ao julgador, que ele deixasse o país, logo depois do ataque e abandonasse sua família. Assim, se sua vida estivesse realmente em perigo, ele não teria deixado sua esposa e seu filho no país. A negativa ao pedido não considerou a existência ou inexistência do ataque e nem negou que no país o estupro seja usado como arma de guerra. $\mathrm{O}$ julgador apenas rejeitou a credibilidade com base em um julgamento moral sobre a conduta do solicitante.

Outro solicitante, do mesmo país, teve seu pedido rejeitado porque o julgador, que não realizou nem solicitou qualquer exame médico, afirmou que não viu nenhuma marca no corpo do solicitante que revelasse a tortura que ele alegava 
ter sofrido. E em relação a outro caso, também do mesmo país, o pedido foi rejeitado porque o solicitante, durante os três meses de sua detenção arbitrária, foi apenas "moralmente torturado". Por "moralmente torturado", o solicitante explicou que foi colocado em uma cela com corpos espalhados pelo chão e sangue nas paredes.

Em outro caso, o solicitante camaronês que esteve injustamente preso durante dois dias, teve seu pedido rejeitado porque suas respostas foram ambíguas: em um momento, disse que foi severamente brutalizado durante sua detenção e, em outro, disse que a "maioria de nós" foi brutalizada durante a prisão. Uma jovem de 15 anos de idade, também do Camarões, que alegou ter sido estuprada e ter testemunhado o espancamento do próprio pai, teve o pedido rejeitado porque não buscou tratamento médico assim que chegou ao país.

\section{1}

\section{A decisão sobre refúgio no Brasil}

Se no Brasil a Anistia Internacional ou outra organização pudesse apontar publicamente os problemas nas decisões, certamente encontraríamos reportados em seus relatórios problemas muito semelhantes àqueles encontrados no Reino Unido. Dentre os casos que foram julgados pelo Conare no Brasil, alguns servem para exemplificar o modelo de investigação da verdade e as suas consequências $^{106}$ : O caso de Alex ${ }^{107}$, que saiu de Maiduguri, no estado de Borno, na Nigéria, em razão da ameaça que o Boko Haram representa para cristãos como ele, ilustra a crítica que fazemos.

Toda sua família foi morta em um ataque realizado à igreja que frequentavam, em junho de 2013. Ele sobreviveu porque se manteve escondido na sacristia por mais de sete horas. Em termos gerais, a Nigéria contabiliza um lado de 6.300 civis mortos ${ }^{108}$, mais de um milhão de deslocados internos no nordeste, e

${ }^{106}$ Os casos referem-se a solicitantes que procuraram atendimento no programa de atendimento a refugiados e solicitantes de refúgio da Cáritas Arquidiocesana do Rio de Janeiro. Estivemos diretamente envolvidos na defesa destes casos: Os casos foram recusados (indeferidos) e alguns acabaram sendo revertidos em segunda instância e outros aguardam ainda solução. Os nomes são todos fictícios.

${ }^{107}$ Nome fictício, como todos os nomes de refugiados e solicitantes mencionados.

108 "UN officials say suffering in Nigeria 'immense,' warn of regional humanitarian crisis”. UN News Center. $\quad 19 / 03 / 2015 . \quad$ (Disponível em: 
47 mil no centro norte, além de 200 mil pessoas que buscaram proteção em outros países, segundo o ACNUR ${ }^{109}$. O Boko Haram, em sua pretensão de implementar a “sharia” em todo o país, era responsável pela violência em várias partes do país, e controlava, naquele período, mais de quinze territórios e ameaçava a estabilidade política. Um dos principais alvos do grupo eram as igrejas e os cristãos.

O pedido de Alex, assim como o de outros quarenta nigerianos julgados na mesma sessão, em meados de 2015, teve o mesmo fim: indeferidos pela plenária, seguindo a orientação dos oficiais do Conare, para os quais faltava credibilidade aos pedidos. O fato relevante, porém, é que os membros da plenária sequer ouviram os relatos sobre os casos e tampouco as objeções que membros da sociedade civil pretendiam opor. Apenas seguiram a sugestão do presidente da sessão e concordaram em indeferir os pedidos.

O primeiro motivo para alegar falta de credibilidade do jovem nigeriano era a falta de provas sobre sua origem: não havia documentos que comprovassem que vinha da região nordeste, onde atua o grupo Boko Haram. Não havia no processo, contudo, qualquer indício de que o entrevistador tivesse sequer se esforçado para obter do solicitante informações que pudessem comprovar indiretamente sua origem. O outro motivo para recusar-lhe o refúgio foi ainda mais significativo: as igrejas evangélicas - que o solicitante frequentava -- segundo o oficial do Conare, não possuem sacristia. Com um pouco mais de esforço de pesquisa, contudo, e o oficial descobriria que as igrejas evangélicas da Nigéria utilizam a palavra “sacristia” para se referir à parte interna da igreja onde se guardam os pertences referentes ao culto ${ }^{110}$. A igreja evangélica episcopal, conhecida como protestante, também possui sacristia em seu interior e utiliza esta nomenclatura ${ }^{111}$.

Em meados de 2015, o Conare teve diante de si o desafio de analisar e julgar um conjunto de casos graves, dentre os quais, solicitações feitas por pessoas que fugiram do Togo e da Nigéria. O Togo, em 2015, contava com mais de nove

http://www.un.org/apps/news/story.asp?NewsID=50376\#.VbWNrLfyNG4) (Último acesso em 26/07/2015).

109 "Subregional Operational Profiles West Africa”, 2015. UNHCR. Statistical Snapshot. (Disponível em: http://www.unhcr.org/pages/49e484f76.html). (Último acesso em 26/07/2015).

${ }^{110}$ Informação disponível em: http://www.hopelutheranchurch.co/altar-sacristy-guilds. (Último acesso em 26/07/2015).

111 "Sacristia é o local no qual os materiais da comunhão, as vestes e os elementos de altar são guardados”. The Episcopal Parish of St. John the Evangelist. Altar Guild Manual. P. 3 e 18. Disponível 
mil refugiados no mundo, além de cerca de 1.200 solicitantes de refúgio ${ }^{112}$. Dentre os pedidos de refúgio apresentados por togoleses, havia o pedido de um jovem chamado Kossi, cujo pai era membro do partido de oposição no Togo, o UFC (Union de Forces for Change). Em 2005, por recusar a filiação no partido governista, o pai do solicitante foi preso e ameaçado de morte. Poucos dias depois, sua casa foi invadida por soldados, seu primo foi baleado e sua irmã violentada sexualmente. Toda a família deixou o Togo, em direção ao Benin, onde foram acomodados no Campo de Agamé. O solicitante saiu de lá em 2013, assim que teve uma oportunidade, porque o campo era vulnerável a ataques e, conseguiu chegar no Brasil.

O contexto político do país é extremamente dramático: o presidente atualmente no poder no Togo, Faure Gnassingbé, foi eleito em eleições contestadas em 2015, e está no governo desde 2005. Ele foi eleito pela primeira vez, substituindo seu pai, em eleições bastante contestadas pela oposição, o que gerou manifestações que resultaram na morte de 500 pessoas e forçou 40.000 pessoas a fugirem do país ${ }^{113}$. A família de Faure Gnassingbé está no poder há 48 anos, um recorde de permanência no poder apenas menor do que aquele da Coréia do Norte ${ }^{114}$.

Por esta razão, é difícil dizer que o Togo tenha democracia eleitoral, especialmente porque as previsões indicam que Gnassingbé se manterá no poder indefinidamente. O partido governista é majoritário no Parlamento e, repetidas vezes, impediu mudanças no sistema eleitoral togolês ${ }^{115}$. O governo e as Forças Armadas do Togo são dominados pela etnia do presidente, Kabyé, enquanto a oposição é majoritariamente composta pelo maior grupo étnico do Togo, Ewé. Há relatos constantes sobre repressão a opositores, assim como relatos consistentes sobre a fuga de togoleses para Benin, gerando forte tensão entre os dois países. Também há notícias sobre presenças de agentes infiltrados no campo de

112 "Subregional Operational Profiles West Africa - Togo. 2015" (Disponível em http://www.unhcr.org/news/briefing/2005/5/427b59764/refugee-numbers-fleeing-togo-slow.html) (Último acesso em 14/06/2016).

113“"Freedom in the World 2011: Togo. 2011”. Freedom House. 2011. (Disponível em https://freedomhouse.org/report/freedom-world/2011/togo) (Último acesso em 14/06/2016).

${ }_{114}$ “Au Togo, l'opposition coincée aprés son échec à la presidentielle”. Le Monde Afrique. 02/05/2015. (Disponível em http://www.lemonde.fr/afrique/article/2015/05/02/au-togo-lopposition-coincee-apres-son-echec-a-la-presidentielle_4626476_3212.html) (Último acesso em 14/06/2016).

115 "Freedom in the World 2015: Togo. 2015". Freedom House. 2015. (Disponível em https://freedomhouse.org/report/freedom-world/2015/togo) (Último acesso em 14/06/2016). 
refugiados de Agamé, assim como notícias de ataques de cidadãos beninenses contra refugiados togoleses, resultando em um incêndio, e na fuga de mais de nove mil refugiados do campo ${ }^{116}$.

Notícias sobre as frequentes tensões no Campo de Agamé demonstram a falta de proteção presente no local ${ }^{117}$. A posição do Conare, no entanto, segundo parecer oficial que acabou por convencer a plenária pelo indeferimento, apontava uma série de motivos que colocavam em questão a credibilidade do pedido. Em primeiro lugar, a própria nacionalidade do solicitante, que, não trouxe qualquer documento de identificação.

Em segundo lugar, o parecer citava que ele não era capaz de explicar com clareza as atividades de seu pai como membro do partido político, durante os anos de 2003 a 2005. E há uma série de outras dúvidas quanto à sua capacidade de lembrar-se de fatos considerados secundários. Um dos pontos que mais chama atenção, no entanto, foi ele ter sido acusado de incoerência porque errou o número de refugiados no campo onde vivia: em vez de dizer que 10 mil, diz o parecer, ele declarou que eram 15 mil pessoas no campo de Agamé. Ao lado do fato de que nem mesmo o Acnur tem sido capaz de estimar com precisão a população daquele campo (e fala em “mais ou menos 15 mil pessoas”) ${ }^{118}$, como se pode esperar que alguém seja capaz de fazer tal cálculo? O fato é que o pedido foi indeferido na plenária e o solicitante espera uma decisão em segunda instância.

Por último, o caso de Jean, que deixou a Costa do Marfim e foi para o Senegal por causa da guerra que explodiu em seu país, tornando-se uma das mais graves crises no continente. Foi membro de um partido chamado "Frente Popular Marfinense” (“Front Populaire ivoirien”, no original). Mais de 24 mil pessoas deixaram suas casas e mais de 70 mil se tornaram refugiados. A mãe de Jean foi degolada, porque a família pertencia a uma etnia (gouro) que se tornou perseguida. No poder do país, a etnia “dioula” acusa os "gouro” por darem apoio ao ex-presidente Laurent Gagbo e por isso, se tornaram vítimas de discriminação e violência, incluindo agressões e prisões arbitrárias. Jean foi para o Senegal, onde

\footnotetext{
116 "Bureau of Democracy, Human Rights and Labor". US Department of State. Benin. 2006.(Disponível em http://www.state.gov/j/drl/) (Último acesso em 14/06/2016).

${ }^{117}$ Joint Assessment Mission:Togolese Refugees in Benin and Ghana and IDPs in Togo. 2006. UNHCR/WFP. (Disponível em http://vam.wfp.org/CountryPage_assessments.aspx?iso3=TGO). (Último acesso em 14/06/2016).

${ }^{118}$ Idem
} 
tentou um pouco de paz e em 2012 resolveu visitar seu pai. Foi então detido e torturado pelas forças de segurança. Finalmente, depois de passar novamente por Senegal, decidiu ir ao Brasil.

Segundo a Human Rights Watch ${ }^{119}$ mesmo depois do fim do conflito, membros das forças de segurança continuaram realizando prisões e detenções arbitrárias, dispensando tratamento cruel e desumano aos presos e detidos. As operações de repatriação foram suspensas no primeiro semestre de 2014, em consequência da epidemia de Ebola ${ }^{120}$, tornando ainda mais dramática a situação do país. E o ACNUR expressava preocupação com a vulnerabilidade dos refugiados retornados. A revolta começou em 19 de setembro de 2002, quando tropas insatisfeitas com a desmobilização do Exército iniciaram um motim.

E logo se transformou em uma rebelião de grande escala. Os muçulmanos do norte passaram a protestar contra o que chamam de discriminação por parte do governo do presidente Laurent Gbagdo. O líder de oposição, Alassanne Quattara, um mulçumano do norte do país, foi impedido de concorrer às eleições presidenciais devido a uma nova lei que determina que os candidatos à Presidência da República precisam ter nascido na Costa do Marfim, assim como seus pais.

Quattara é acusado de ser natural de Burkina Faso, mesmo já tendo ocupado anteriormente o cargo de primeiro-ministro da Costa do Marfim. Para alguns muçulmanos, a nova lei simboliza a marginalização do líder de oposição. Quattara negou estar envolvido na rebelião. Sua casa na capital Abidjan chegou a ser atacada, e o líder muçulmano passou várias semanas sob a proteção do Exército francês antes de se mudar para o Gabão. Burkina Faso e Libéria são apontados como apoiadores dos rebeldes ${ }^{121}$.

Tropas da ONU mantêm uma paz precária no país desde 2002. O Presidente Laurent Gbagbo, é cristão e tem suas bases eleitorais no Sul. Ele enfrentou Alassane Ouattara, muçulmano muito popular no Norte do país, nas eleições presidenciais de setembro e outubro de 2010. Conforme a comissão

119 “World Report 2014” Human Rights Watch. 2014.P. 99 (Disponível em https://www.hrw.org/world-report/2014.) (Último acesso em 15/06/2016)

120 "A new displacement crisis in West Africa”. s/d (Disponível em http://www.unhcr.org/cotedivoire-edge.html) (Último acesso em 15/06/2016).

121 "Entenda o conflito na Costa do Marfim”. BBC Brasil. 10/02/2003. (Disponível em http://www.bbc.com/portuguese/noticias/2003/030210_costadomarfim.shtml) (Último acesso em 15/06/2016). 
eleitoral independente da Costa do Marfim, Ouattara foi o vencedor das eleições. Apesar de tudo, Gbagbo não cedeu à presidência a Outtara, que, por sua vez, foi reconhecido pela ONU, a União Europeia e os Estados Unidos como o vencedor nas eleições

Seguiram-se os conflitos que mergulharam o país em enfrentamentos armados e perseguições baseadas em filiação religiosa. O embate entre cristãos e muçulmanos deu dimensão internacional à crise na Costa do Marfim. O conjunto da população da África subsaariana compõe-se de 57\% de cristãos e $29 \%$ de muçulmanos. Mas nos países acima da bacia do Congo, as proporções são mais próximas e as clivagens internas mais nítidas, como na Nigéria e no Sudão, onde surgiram conflitos sangrentos entre as duas comunidades ${ }^{122}$.

A despeito de todas as informações disponíveis e de recomendações sobre a instabilidade no país, o oficial do Conare se posicionou contra o seu reconhecimento como refugiado e a plenária seguiu a orientação. Novamente, um dos principais motivos para a recusa era a falta de credibilidade. Em primeiro lugar, o parecer do Conare afirmava que ele não mostrou que tivesse função relevante no partido que o pudesse transformar em um alvo de perseguições. E embora Jean, que já havia sofrido com a morte brutal de sua mãe, tenha relatado sua prisão e tortura, a posição do Conare era de que a Costa do Marfim “caminhava para a normalidade”, negando relatórios consistentes sobre a instabilidade no período pós-eleições, quando Jean decidiu deixar o país

E, por fim, o oficial do Conare acusou a falta de credibilidade porque Jean foi incapaz de lembrar corretamente o nome do partido do qual fazia parte: em vez de “Front Populaire Ivoirian”, dissera "Force Populaire Ivoirian”. Em nenhum momento, no entanto, ele teve a chance de explicar seu "lapso”.

\section{2}

\section{A desconfiança como método}

Até o final de 2015, pouco mais de três mil congoleses chegaram ao Brasil, superando as dificuldades para conseguir visto e para conseguir o dinheiro

122 “Conflito entre cristãos e muçulmanos coloca Costa do Marfim no foco mundial”. Portas Abertas. 31/03/2011.

(Disponível

em https://www.portasabertas.org.br/noticias/2011/04/noticia7001/) (Último acesso em 15/06/2016). 
suficiente para a viagem. Pelo menos 968 já foram reconhecidos refugiados - a maior parte morando no Rio de Janeiro -- e 2.167 aguardam decisão ${ }^{123}$. Foi principalmente no início dos anos 2000 que os congoleses começaram a chegar, provavelmente seguindo a rota dos angolanos que, durante os anos 1990, vieram em número significativo, fugindo da guerra civil em seu país.

A República Democrática do Congo, um dos países mais ricos em recursos naturais do mundo - incluindo cobre, diamantes, ouro, além de terras férteis e energia hídrica suficiente para iluminar toda a África - tornou-se um dos países mais violentos, pobres e devastados do mundo, sem que exista uma solução em curto prazo. Atravessando golpes, guerras e conflitos desde sua independência, na década de 1960, o país tem um saldo estimado de seis milhões de vítimas fatais, o maior, portanto, de todas as guerras desde a Segunda Guerra Mundial, razão pela qual muitos falam em o "holocausto africano".

O Congo também é conhecido como "capital mundial do estupro”: centenas de milhares de mulheres têm sido sistematicamente violentadas nos últimos anos, seja por grupos rebeldes ou mesmo por membros das forças armadas do país: são 48 mulheres estupradas por hora ${ }^{124}$. A violência sexual contra as mulheres tornouse comum mesmo na vida cotidiana das cidades, mas a violência e brutalidade do estupro como arma de guerra ganhou contornos sem precedentes, mesmo para um lugar marcado por "senhores de guerra" e crianças soldados: entre os horrores narrados, há casos de mulheres que, depois de estupradas por vários homens, foram mortas por um rifle introduzido em seu corpo ${ }^{125}$.

O conflito na República Democrática do Congo produziu o deslocamento de cerca de 3,8 milhões de pessoas, dentro do próprio território. E mais de um milhão de pessoas de deslocados para os países vizinhos ${ }^{126}$. O fluxo de refugiados cresceu

\footnotetext{
${ }^{123}$ Sobre os índices de deferimento e indeferimento, ver os dados compartilhados pelo Conare. Os dados estão disponíveis no site do ACNUR (http://www.acnur.org/t3/portugues/recursos/estatisticas/dados-sobre-refugio-no-brasil/) (Último acesso em 15/06/2016)

124 "Milícias usam violência sexual como arma de Guerra no Congo". BBC Brasil. 24/08/2012. (Disponível em http://www.bbc.com/portuguese/noticias/2012/08/120814_congo_estupro_ru.shtml) （Último acesso em 29/05/2016).

125 "The world's worst war”. Jeffrey Gettleman. New York Times. 15/12/2012. (Disponível em http://www.nytimes.com/2012/12/16/sunday-review/congos-never-ending-war.html?_r=0) (Último acesso em 27/05/2016).

126 "Democratic Republic f the Congo: A migration history marked by crises and restrictions". Migration Policy Instituto. 20/04/2016. Marie-Laurence Flaxaus e Bruno Schoumaker, pág. 06/07
} 
principalmente a partir dos anos 1990. Cerca de 80 mil refugiados da RDC viviam nos países vizinhos durante aquela década. Ao final dos anos 1990, porém, o número subiu para 250 mil.

E atualmente (março de 2016) se contabiliza cerca de 450 mil refugiados em países africanos. Depois de Angola, a maioria vive em Uganda (202 mil), Ruanda (75 mil), Tanzânia (64 mil) e Burundi (53 mil) e República do Congo (32 mil) ${ }^{127}$ É o país com a mais longa e cara missão da ONU, com efetivo de 20 mil homens, incapazes, contudo, de evitar os massacres, chacinas, estupros coletivos, sequestros de crianças, dentre outras violências brutais, utilizadas por todas as partes envolvidas, como forma de intimidar e derrotar física e moralmente os oponentes.

Dentre as tantas pessoas que vieram ao Brasil em busca de proteção, vale destacar o caso de Huguette. Em agosto de 2010, esta jovem mulher congolesa chegou ao Brasil com seus dois filhos pequenos e solicitou refúgio na delegacia da Polícia Federal no Rio de Janeiro. Ela foi entrevistada pelo oficial de elegibilidade do Comitê Nacional para os Refugiados (CONARE), e reportou ter sido injustamente perseguida, depois que o jornalista e ativista de direitos humanos com o qual trabalhava foi considerado desaparecido e encontrado morto dias depois.

O desaparecimento e morte de Floribert Chebeya, diretor da organização “La Voix des Sans Voix”, ganhou grande repercussão não apenas entre os ativistas que atuam na República Democrática do Congo, mas também entre todas as pessoas preocupadas com as condições políticas naquele país, incluindo as instituições internacionais de direitos humanos, como Human Rights Watch e Anistia Internacional ${ }^{128}$.

A despeito de todas as notícias sobre a situação do país e a despeito dos documentos que provavam parte de suas alegações, o pedido de Huguette foi

(disponível em http://www.migrationpolicy.org/article/democratic-republic-congo-migrationhistory-marked-crises-and-restrictions) (Último acesso em 13/05/2016).

127 "Congolese (DRC) refugees". 2013. (Disponível em http://www.resettlement.eu/page/congolese-drc-refugees) (Último acesso em 29/05/2016).

${ }_{128}$ "DR Congo: Prominent Human Rights Defender Killed". Human Rights Watch. 03/06/2010. (Disponível em https://www.hrw.org/news/2010/06/03/dr-congo-prominent-human-rightsdefender-killed) e "Human Rights activisti targered in Democratic Republico of Congo". Amnesty International. 30/06/2010. (Disponível em https://www.amnesty.org/en/latest/news/2010/06/human-rights-activists-targeted-democraticrepublic-congo/) (Último acesso em 14/06/2016). 
indeferido pelo CONARE, por "falta de credibilidade". Naquele mesmo período, algumas dezenas de congoleses tinham solicitado refúgio no Brasil alegando ligações com Chebeya, o que motivou a postura restritiva por parte do Comitê. O fato, porém, é que em relação ao caso de Huguette não havia nenhum dado relevante que pudesse fazer crer que estivesse mentindo. E a falta de provas irrefutáveis não seria motivo para a negativa, uma vez a dúvida deve sempre favorecer o solicitante, em consideração à precariedade de sua situação e à emergência de sua fuga, como recomenda o manual do ACNUR (2013, p. 54) em suas diretrizes.

Chebeya foi encontrado morto na manhã do dia 02 de junho de 2010. Tinha 47 anos e desapareceu juntamente com o motorista Fidèle Edadi na noite anterior, quando se dirigiam para uma reunião na Sede da Inspetoria Geral da Polícia. Seu corpo foi encontrado no banco de trás de seu carro, abandonado à beira de uma rodovia a oeste de Kinshasa, capital do país, com as mãos amarradas às costas. O corpo do motorista foi encontrado no dia seguinte, em outra área nos arredores da cidade.

Destacado defensor dos direitos humanos e alvo de constantes ameaças ao longo dos anos, Chebeya pretendia apresentar um relatório detalhado sobre as condições dos presídios locais. Há algum tempo vinha recebendo ameaças por causa de sua luta em prol dos direitos humanos. Ele chegou a ser preso pelas autoridades congolesas por protestar contra um contrato firmado pelo governo e uma importante empresa francesa, que tinha por objetivo exploração de recursos naturais em Katanga. Chebeya denunciou à Anistia Internacional que estava sendo perseguido e suspeitava estar sob vigilância dos serviços de segurança.

A morte de Floribert Chebeya é apenas uma dentre uma grande lista de jornalistas mortos naquele país, onde há imensas listas de opositores e ativistas ameaçados ou vítimas de arbitrariedades. A República Democrática do Congo está em $148^{\circ}$ lugar no "ranking” de liberdade de imprensa, numa lista com 178 países. De acordo com um relatório da organização “Jornalista em perigo”, foram cometidas 87 violações a liberdade de imprensa em 2010, incluindo um assassinato, 17 encarceramentos, 27 interpelações, sete agressões, oito ameaças e 
13 medidas administrativas ou judiciárias, além de 14 entraves à livre circulação de informação ${ }^{129}$.

Naquele ano, a Human Rights Watch declarava em relatório (2010) o aumento da violência e abusos brutais a direitos humanos na República Democrática do Congo. Reportava o massacre de pelo menos 2500 civis na região leste do país e a existência de sete mil mulheres e meninas submetidas a violência sexual. Mais de um milhão de pessoas, segundo o relatório, foram forçadas a sair de suas casas, aumentando para dois milhões o número total de deslocados, sendo que a maioria sofria com falta de acesso a assistência humanitária e se viu obrigada a retornar atrás de comida, correndo riscos. As operações militares realizadas na região oriental do Congo foram acompanhadas de violência sexual contra mulheres e meninas, dando à região o título de pior lugar do mundo para ser uma mulher.

Por conta de sua ligação profissional com Chebeya, Huguette foi presa poucos dias depois e levada à prisão “Kin Maiziere”, que, embora declarada oficialmente fechada, era conhecida como um centro de torturas. Por causa de golpes que recebeu na cabeça com um fuzil, Huguette sofreu descolamento de retina, e por algum tempo não pode enxergar. Só foi colocada em liberdade depois que a morte de Chebeya provocou reação inesperada. Mesmo depois de solta, voltou a receber ameaças por cartas e por telefone, razão pela qual não viu outra saída que não fugir do país.

Diferentemente da maior parte dos solicitantes de refúgio que foge da República Democrática do Congo, Huguette trazia documentos pessoais comprovando a sua identidade e nacionalidade e também a identidade das crianças. Observando seu passaporte, podia se verificar que ela foi obrigada a fugir com extrema urgência. Contando com ajuda de pessoas influentes, conseguiu um passaporte onze dias antes da fuga e visto com apenas um dia de antecedência. Ela também tinha documentos comprovando sua formação em jornalismo e provando que esta era sua atual ocupação. E, por fim, um laudo médico (de um hospital público brasileiro) comprovava as lesões nos olhos, como havia relatado.

\footnotetext{
129 "Journalist in Danger releases annual report revealing alarming plight of journalists". Reporter Without Borders. 15/12/2010. (Disponível em https://rsf.org/en/news/journalist-danger-releasesannual-report-revealing-alarming-plight-journalists) (Último acesso em 14/06/2016).
} 
Em dezembro de 2011, foi a vez de Marlene, outra jovem mulher congolesa. Junto com uma ativista de direitos humanos e mais três jovens com quem trabalhava no mesmo escritório, ela chegou ao Brasil e solicitou refúgio. A exemplo do que aconteceu com Huguette, o pedido de Marlene foi rejeitado pelo CONARE, igualmente por falta de credibilidade. Dentre as cinco pessoas que faziam parte do mesmo grupo, somente ela teve seu pedido negado, depois de um longo debate a respeito de incoerências ou lacunas em seu depoimento, todas provocadas, aliás, por uma entrevista mal conduzida. Não havia no processo nada de relevante que tornasse seu caso mais frágil. A possibilidade de resposta negativa, aliás, oscilou em relação a cada uma das cinco pessoas do grupo e acabou finalmente se tornando o destino do pedido de Marlene.

Todas as suas declarações foram confirmadas por relatórios de instituições de direitos humanos e as supostas lacunas em seu depoimento não eram mais graves do que as observadas em quase todos os casos, lembrando que são pessoas que passaram por situações extremamente violentas e que estão cientes de que seu depoimento está sob avaliação em tempo real. A fuga de Marlene e seu grupo estava ligada às perseguições perpetradas pelo governo contra opositores políticos, e, em especial, aos militantes do partido UDPS (União pela Democracia e Progresso Social), que tinha como líder um conhecido e antigo oposicionista, chamado Étienne Tshisekedi.

Diversos militantes deste e de outros pequenos partidos de oposição foram arbitrariamente presos e enviados à prisão central de Kinshasa, "Makala”, famosa pelos casos de torturas, espancamentos e privações de alimentação e agua potável. O Ministro de Justiça congolês já havia se referido à prisão como "casa de morte” ${ }^{130}$. Em junho de 2011, contabilizava-se aproximadamente 1.700 militantes presos em suas dependências. Em novembro de 2011, o presidente da UDPS deu um ultimato de 48 horas ao presidente do país para que ele libertasse os simpatizantes de seu partido, sob ameaça de conclamar os militantes do partido a um ataque contra a prisão.

Havia ainda relatos consistentes sobre fraudes nas eleições, comprovando que as objeções levantadas pelos partidos de oposição, principalmente por

\footnotetext{
130 "The treatment of prisioners and prison conditions in Kinshasa". Immigration and Refugee Board of Canada: the treatment of prisoners. 31/03/2010. (Disponível em https://www.ecoi.net/local_link/137718/237995_en.html) (Último acesso em 14/06/2016).
} 
Tshisekedi - certamente o mais prejudicado por elas - tinham fundamento. Eram comuns os relatos de registro duplo de eleitores: o presidente da Comissão Eleitoral Nacional Independente (CENI) constatara a existência de milhares de eleitores duplamente registrados, em diversas regiões do país, principalmente naqueles onde a base de apoio da oposição era maior, o que levou a UDPS a convocar manifestações para divulgar o problema dos doublons (registros duplos).

Além disso, agentes de partidos políticos de fato vinham denunciando as irregularidades no processo eleitoral. Pela observação desses agentes, houve fraudes eleitorais graves e passiveis de anulação da eleição em sete importantes cidades. Entretanto, a lei eleitoral estipula que a anulação só pode se feita mediante julgamento da Corte Suprema, o que não foi feito ${ }^{131}$.

Quanto à repressão de manifestações e de opositores, os observadores das Nações Unidas reportaram 118 casos de violação de direitos humanos em meses anteriores ao lançamento da campanha oficial presidencial, incluindo violência perpetrada por policiais e outros agentes do Estado, uso desnecessário de força contra manifestações, prisões arbitrárias direcionadas aos lideres de oposição partidária. O exército reprimiu violentamente uma manifestação pacífica da UDPS, prendendo 32 membros do partido e ferindo vários outros. Cerca de 10 apoiadores da UDPS ficaram feridos e um foi morto em repressão policial à uma manifestação contra o governo atual. Notícias tratam expressamente da repressão direta contra Tshisekedi, proibido pela polícia de se dirigir ao local de votação. Inúmeras matérias falam dos confrontos e das mortes provocadas.

Não obstante todos os graves fatos relatados pelas agências de notícias e pelas organizações de direitos humanos, o pedido de Marlene não foi aceito. Faltava-lhe credibilidade. Um julgamento sobre a verdade e a mentira e sobre a moral da solicitante. As supostas incoerências ou contradições foram utilizadas para justificar o indeferimento do pedido, mas o resultado poderia ter sido diferente se ela tivesse a chance de opor seus argumentos e defender-se das suspeitas. Nada de mais concreto ou material foi levantado contra ela e não havia prova definitiva ou mesmo indícios consistentes de que estivesse mentindo.

131 “DR Congo: 24 killed since eletion results announced”. Human Rights Watch. 21/12/2011. (Disponível em https://www.hrw.org/news/2011/12/21/dr-congo-24-killed-election-resultsannounced) (Último acesso em 14/06/2016). 
Marlene teve seu pedido recusado, mas qualquer outra pessoa de seu grupo poderia ter recebido o mesmo resultado. 


\section{Guerra, biopoder e soberania}

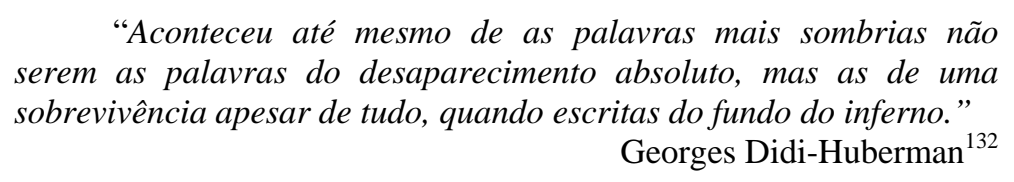

Na passagem da soberania clássica para a soberania do biopoder, assistimos a alteração nos dispositivos de controle social e nos modos como a soberania decide pela legitimidade da violência. O mundo vive hoje a guerra generalizada e global, o que significa, por um lado, ampliação e expansão dos conflitos e massacres e, por outro, a intervenção policial como forma de regulação social. Os refugiados que fogem do conflito na Síria ou no Iraque - exemplos de conflitos transnacionais - são agora atacados por policiais nas fronteiras da "fortaleza europeia”. Este é a guerra em suas duas dimensões e vertentes: local e global, conflito e policiamento.

Nas palavras de Hardt e Negri (2005), a “soberania imperial” é o palco para o estado de guerra global, em que a exceção se torna a regra. Para Frédéric Gros (2009), nos “estados de violência”, as guerras e a violência são justificadas em nome da preservação dos viventes e em defesa das vítimas. Neste estado de guerra global ou de violência como forma de governo, em que a guerra convive com a gestão policial permanente, os inimigos são voláteis e incessantemente inventados, e a violência é legitimada a posteriori. As guerras são explicadas apenas em termos de inimigos e vítimas. Neste sentido, o mesmo regime de produção do inimigo - como o terrorista islâmico hoje - justifica a criação da imagem do refugiado como a vítima inocente cuja vida está por um fio. A soberania não apenas está em crise, mas ela mesma é a crise. Entre o massacre e a ordem social, o poder biopolítico soberano pretende utiliza a crise para definir o

${ }^{132}$ DIDI-HUBERMAN,Georges. A sobrevivência dos vagalumes. Belo Horizonte, Editora UFMG, 2011, pág.131. 
estatuto do vivente e, deste modo, estabelecer o controle sobre os fluxos de pessoas.

Se no passado a "ameaça comunista" foi uma das manifestações da soberania ameaçada pelo inimigo disperso e não localizável, os “terroristas” encarnam hoje a ameaça subterrânea e, junto com eles, os migrantes e refugiados, imaginados como bárbaros rudes, negros incivilizados ou homens bomba, independentemente de sua origem. Eles são a imagem do risco e do inimigo em potencial, contra os quais se erguem os muros e as tropas. O "muçulmano radical" pode ser eleito mesmo entre os nacionais, filhos de migrantes e refugiados e a questão não é somente a potencialidade do inimigo, mas a eventualidade que a brecha abre. E a brecha, neste caso, é a mobilidade e a possibilidade de invocar a lei para obter passagem pelas fronteiras. O refugiado é tomado como suspeito porque ele é uma possibilidade jurídica e política para esta passagem.

A guerra é muito maior e mais comum do que pensamos e é mesmo o estado normal do mundo. Pensar sobre o instituto do refúgio, portanto, inclui, sobretudo, uma reflexão sobre guerra, capitalismo e democracia. Principalmente sobre democracia. E não apenas porque a segurança dos refugiados depende de democracia nos países de acolhida, mas porque eles, os refugiados, são a constante advertência sobre a importância de lutar por democracia. Neste sentido, vivemos um mundo em que a paz e a democracia estão em permanente estado de suspensão.

Tratar da questão dos refugiados e da crise dos refugiados como efeitos fragmentados de eventos acidentais, desconectados ou inevitáveis e tratar o direito de refúgio como um tema específico, pertinente apenas ao campo dos direitos humanos e do direito humanitário, é perder a sensibilidade diante das relações que determinam a continuidade incessante do sofrimento em que vive a maior parte da humanidade e, sobretudo, perder-se diante da condescendência impotente.

\section{1}

\section{A crise "contra" a democracia}

Se seguimos os traços deixados pelos sujeitos em suas fugas, talvez sejamos capazes de ver as conexões entre as diferentes formas de atuação do biopoder e sua natureza conflitiva frente à democracia. Os sírios, por exemplo, fogem de um 
conflito que, de certo modo, surge como reação aos ventos democráticos da “Primavera Árabe”. A autoimolação do jovem tunisiano expressava a indignação que se alastrou pelos países vizinhos, derrubando antigas e sólidas ditaduras, mas também desencadeando reações que culminaram em guerras, como acontece hoje na Síria ${ }^{133}$.

No período entre 2010 e 2015, configurou-se um novo ciclo de lutas global, do qual emergiu um complexo jogo de “contágios, proliferações, emergências, reviravoltas, restaurações e contínua renovação de ações criativas e constituintes” ${ }^{134}$. Contagiados pelos acontecimentos, surgiram as acampadas e o movimento "15 M” na Espanha, em 2011, e a ocupação da Praça Syntagma, na Grécia. Na Islândia, no ápice da crise financeira, a população colocou em questão o poder financeiro. No outono de 2011, os ventos chegaram aos Estados Unidos, na forma do movimento "Occupy”, transformando-se no estopim para as ocupações que surgiram em centenas de cidades do mundo inteiro, com o slogan "nós somos os 99\%”. De 2011 a 2013, a América Latina testemunhou a luta dos estudantes no

${ }^{133}$ De certo modo, pode-se dizer que o conflito iniciou no dia 18 de março de 2011, quando o governo sírio abre fogo contra um grupo de estudantes que fazem um graffiti em protesto ao regime de Bashar al-Assad. Candidato único pelo Partido Árabe Socialista Baath, Assad fora eleito mediante referendo no dia 10 de julho de 2000. Exatamente um mês depois da morte de seus pai, Hafez al-Assad, que se manteve no poder desde 1971. Embora apresentasse uma tendência à abertura, - uma das primeiras medida de Assad depois de assumir a presidência foi ordenar a libertação de 600 presos políticos - não é isso o que acontece. E é dando continuidade a politica de seu pai, que busca a estabilidade por meio da repressão, que Assad responde ao protesto dos estudantes enviando tropas do exercito para reprimir o protesto. A cidade de Deera sai em defesa dos alunos. Quatro pessoas são mortas. Um dia depois, mais uma vítima, quando as forças de Assad voltam a abrir fogo contra os civis presentes no velório das vitimas. É importante afirmar que os protestos na Síria são contagiados e passam a fazer parte de uma série de manifestações que ocorreram no Oriente Médio e no Norte da África, a partir do dia 18 de dezembro de 2010. Essa onda é deflagrada quando o jovem tunisiano, Mohamed Bouazizi, ateou fogo ao próprio corpo em protesto em frente a sede do governo. $\mathrm{O}$ ambulante protestava contra as autoridades locais que após várias tentativas de extorsão lhe apreendem de sua barraca de frutas, alegando que a venda na rua era proibida. O trabalho lhe rendia 75 dólares mensais com os quais ajudava a sustentar da casa, que dividia com sua irmã e sua mãe. Cinco mil pessoas participaram de seu funeral. Os protestos na Tunísia pressionam o presidente Zine al-Abidine Ben Ali estava no poder havia mais de 20 anos, a renunciar. No Egito, se seguiram protestos que antecederam a queda do presidente Hosni Mubarak, e a um conflito na Líbia, que resultou no fim do regime de Muammar Khadafi. Além das revoluções na Tunísia e no Egito, os ventos da chamada primavera árabe também desencadearam reações violentas na Líbia e na Síria, grandes protestos na Argélia, Iraque, Jordânia, Omã e Iêmen, e protestos menores no Iraque, Líbano, Mauritânia, Marrocos, Arábia Saudita, Sudão e Saara Ocidental, sem contar os inúmeros protestos e manifestações despertadas na América Latina.

134 MENDES, Alexandre. “Ocupações estudantis: novas assembleias constituintes diante da crise?”. Uninomade Brasil. (Disponível em http://uninomade.net/tenda/ocupacoes-estudantisnovas-assembleias-constituintes-diante-da-crise-2/) (Último acesso em 02/07/2016). 
Chile, o movimento mexicano “\#YoSoy132” e as “Jornadas de Junho” no Brasil, inspirados na ocupação do parque Gezi, em Istambul.

Em reação a esta enorme força viva de produção democrática, uma série de violentas restaurações desembocaram em guerras, massacres, perseguições e novas formas de ditadura, mostrando, uma vez mais, que cada uma das guerras, desde Síria até Ucrânia, é a oportunidade para a restauração e reacomodação da soberania imperial. O mundo se tornou novamente revirado pela ação das elites nacionalistas, grupos radicais religiosos e as tradicionais forças da OTAN, Estados Unidos, Rússia e demais potências europeias.

Em outras partes do mundo, a guerra também significou a repressão a ativistas e destruição das experiências alternativas de democracia (como as ocupações e acampadas) e o fim do ciclo de governos progressistas na América Latina, com a restauração das forças conservadoras em boa parte dos países da região, incluindo no Brasil, onde a criatividade das "jornadas de junho" foi engolida pela repressão e pela chantagem do esquema da política representativa. E na Europa, os atentados terroristas se tornaram a justificativa para mascarar a crise da soberania em proliferação do nacionalismo com tons fascistas, recrudescimento dos aparatos de segurança, xenofobia e repressão aos migrantes e refugiados ${ }^{135}$.

\section{2}

\section{A crise ilimitada e incessante: exceção como normalidade}

A crise é certamente muito maior do que a crise dos migrantes e refugiados. E muito mais grave do que expressam os relatórios oficiais sobre os mortos e feridos, sobre os deslocados e refugiados. Se levássemos em conta o número de crianças mortas por desnutrição ou em decorrência de doenças facilmente evitáveis”, ou ainda todas as pessoas que foram arbitrariamente deslocadas em razão da gentrificação das cidades ou da construção de grandes obras, a crise não seria exatamente a excepcionalidade que querem nos fazer crer.

Em muitos casos, a violência urbana não pode ser dissociada da guerra, como bem demonstram Angola, Colômbia ou Venezuela, dentre muitos exemplos,

135 MENDES, Alexandre. "Ocupações estudantis: novas assembleias constituintes diante da crise?”. Uninomade Brasil. (Disponível em http://uninomade.net/tenda/ocupacoes-estudantisnovas-assembleias-constituintes-diante-da-crise-2/) (Último acesso em 02/07/2016). 
com a violência de milícias, batalhas entre guerrilheiros e paramilitares e as disputas entre diferentes grupos armados. Mas também poderíamos falar do Brasil e de como a guerra contra as drogas justifica o controle social dos pobres e negros, ou como a gestão das grandes cidades se torna cada vez mais violenta contra os pobres, desmontando suas potências de colaboração, criatividade e, enfim, de trabalho vivo.

E poderíamos falar da guerra contra as pessoas que fogem de seus países em busca de paz, justiça e segurança. A partir desta perspectiva, o instituto do refúgio é, por vezes, a única brecha encontrada em meio aos obstáculos impostos à mobilidade. As restrições aos refugiados e migrantes, porém, não são parte de uma exceção, mas sim a violência calculada e cruel que se tornou o controle biopolítico - medida pelo número de vítimas, mas também pela burocracia, pela expropriação de vida, trabalho, produção e criação que este sistema promove.

E ainda haveria muitos números a acrescentar à crise além das pessoas que morrem nas fronteiras e nas travessias em busca de um lugar seguro: os jovens encarcerados, os ativistas mortos, presos e agredidos, os povos indígenas acuados pelo agronegócio, as mulheres violentadas, sem falar nos moradores de rua, nos endividados, enfim, todos os que sucumbem neste mundo sitiado por aquela coisa “inominável”, como dizem Deleuze e Guatarri (2010) sobre o capitalismo.

\section{3}

\section{A soberania imperial e a guerra global}

Como disseram uma vez Hardt e Negri, “o mundo está mais uma vez em guerra, mas esta vez as coisas são diferentes” (2005, p.21). Em vez do tradicional conflito armado entre estados soberanos, a guerra se transformou num fenômeno geral, global e interminável. A guerra global segue a nova forma de soberania supranacional do regime do biopoder, que os autores chamam de Império. A manifestação do poder soberano - em sua dimensão de biopoder imperial - se dá pela guerra, determinando o controle e a disciplina. A guerra funciona como controle biopolítico, e, portanto, ela mantém a capacidade de destruir e massacrar, mas também de produzir.

Se a guerra é o fato consumado ou uma virtualidade, a espreita, é porque vivemos outra economia de poder: por vezes, a guerra é a última manobra, adiada 
e excêntrica. Por outras, é tomada como plano de gestão e plano sobre o qual se fará a gestão das populações e de sua produção. De uma maneira ou de outra, a guerra será aplicada na imanência das relações sociais, dentro da normalidade e das regras. Ela funciona como controle do corpo social, e também ela suspende indefinidamente a democracia e quaisquer possibilidades de abertura democrática. Toda tentativa ou experiência por alguma pressão democrática é prontamente respondida pelos poderes com a guerra, o que confirma a inversão na relação entre política e guerra. Ela tende mesmo a tornar-se uma forma de governo (Hardt e Negri, 2005, p.427).

Desde o início do século XX o mundo não voltou realmente a viver em paz, dizem Hardt e Negri (Ibidem, p. 64). A Segunda Guerra veio logo na sequência dos acontecimentos da Primeira e foi sucedida pela Guerra Fria, num certo sentido, uma Terceira Guerra Mundial, que abriu caminho para o atual estado de guerra civil imperial. Para os autores, nossa época poderia ser encarada como a Quarta Guerra Mundial. Hoje, o estado de guerra tornou-se interminável, onde os estados-Nação soberanos já não definem os lados do conflito, como era característica da Guerra Fria.

A estratégia de dissuasão recíproca dos Estados Unidos e da antiga União Soviética transformou a guerra: ela era menos dirigida para a defesa contra uma grande ameaça e mais centrada em pequenas ameaças fragmentadas. Menos preocupada com a destruição total do inimigo e mais inclinada para a transformação e mesmo a produção do inimigo. No lugar dos combates total em larga escala, as potências mundiais começaram a desenvolver ações policiais de alta intensidade, como foi a intervenção norte-americana no Vietnã e na América Latina e a ação soviética no Afeganistão.

Os inúmeros conflitos que explodem pelo mundo, alguns breves e limitados geograficamente, outros, prolongados e expansivos, segundo eles, não são casos de guerra, mas sim de "guerra civil”. Trata-se, ainda, segundo a leitura que fazem aqueles dois autores, de uma guerra que não é mais travada no contexto de um espaço soberano nacional, mas no ambiente global.

Mesmo a estrutura do direito internacional que regulamenta a guerra foi deixada de lado e, deste modo, todos os conflitos armados devem ser considerados como "guerras civis imperiais", mesmo que estados estejam envolvidos e mesmo que cada um deles seja um conflito local e específico (Hardt e Negri, 2005, p. 22). 
Dizer isso não significa que todos os conflitos mobilizem toda soberania “imperial”, mas o fato é que eles acontecem no interior do sistema imperial global e não podem ser encarados isoladamente, se não como partes de uma grande constelação, em que zonas de guerra estão ligadas entre si.

A guerra que o mundo contemporâneo vive hoje, fantasiada de guerra religiosa entre cristãos e muçulmanos, apenas mascara uma profunda mudança histórica, assinalada, em especial com os atentados de 11 de setembro de 2001. Quanto à paz, não somos capazes de imaginá-la ou de ter esperanças que ela verdadeiramente aconteça desde que passamos a viver este generalizado estado de guerra global.

A primeira chave para entender o estado de guerra global, segundo Hardt e Negri (2005), está no conceito de exceção. A era moderna nasce na Europa justamente como reação à generalização das guerras e o objetivo principal do pensamento político moderno era separar a guerra da política. Para Carl von Clausewitz, expressão singular do pensamento político moderno, a guerra é a continuação da política por outros meios e, portanto, completamente exterior aos conflitos políticos que se manifestam em uma sociedade.

A mesma análise seria feita por Carl Schmitt, para quem todos os motivos e atos políticos baseiam-se fundamentalmente na distinção amigo-inimigo, o que significa, em última instância, que o único inimigo possível de um estado é um outo estado. O objetivo da soberania moderna, portanto, era banir a guerra do terreno interno. A guerra era pensada, assim, como um limitado estado de exceção.

Na soberania pós-moderna do Império global, com o declínio da soberania dos estados-nação, em vez da paz perpétua sonhada por Kant, vivemos o estado de exceção permanente e generalizado, tanto no nível do espaço interno dos estados quanto nas relações internacionais, o que significa uma contradição em relação ao conceito tradicional de exceção, segundo o qual a lei é temporariamente suspensa para que o soberano proteja a república.

Hoje, portanto, a guerra se transformou numa "relação social permanente" (Hardt e Negri, 2005, p. 33), e princípio básico de organização das sociedades, de forma que a política vem se tornando cada vez mais a guerra conduzida por outros meios, invertendo-se assim a fórmula de Clausewitz. A guerra transformou-se na matriz geral de todas as relações de poder e técnicas de dominação, esteja ou não 
envolvido o derramamento de sangue (Ibidem, p. 34). A força letal deixou de ser o elemento final das sequências de poder para se tornar o primeiro e fundamental elemento, constituindo a base da política (Ibidem, p. 44).

A outra característica do estado de guerra é a quase indistinção entre política interna e política externa, quanto à relação entre política, riscos e segurança. A fim de garantir a segurança, é cada vez menor a diferença entre as atividades militares e as atividades policiais, entre o que está dentro e o que está fora do âmbito do estado. As ações policiais de baixa intensidade se encontram com as ações militares de alta intensidade, mas também as ações policiais se dão em alta intensidade.

E mesmo entre o "inimigo", tradicionalmente de "fora", e as "classes perigosas”, normalmente “dentro” do estado, há uma indistinção crescente. Quanto a isso, a mistura e a fusão entre guerra e policiamento tem significado um duro obstáculo para as forças e lutas por transformação social, como recentemente se pode observar em várias partes do mundo: Oito mortos e dezenas de feridos por causa de repressão policial a professores que protestavam contra a reforma educacional, em Oaxaca, no México. Cenas de guerra nas ruas de Paris, por causa dos protestos contra austeridade. Armas "não letais" contra os estudantes que ocuparam escolas em São Paulo, Rio de Janeiro e outras cidades do Brasil, em protesto contra a política de educação. E o que dizer então dos policiais jogando gás lacrimogêneo contra os refugiados na fronteira da Hungria? Tudo isso no primeiro semestre de 2016.

O inimigo, por sua vez, deve ser continuamente inventado e, paradoxalmente, não deve ser nunca vencido. E, quando vencido, deve haver outro, que possa justificar a disciplina e o controle, já que cada indivíduo singular pode se levantar como inimigo do soberano imperial. A paz e a guerra não se diferenciam mais e fazem ambas parte da mesma matriz biopolítica (Negri, 2003, p. 191).

A luta contra o inimigo disperso, não-identificável e não-soberano - e que, portanto, é externo e interno - termina por desagregar a soberania do próprio estado-nação e aparece como ameaça ao comando (Negri, 2003, p.77). Da perspectiva molar, a forma ou a natureza da soberania não se modificou durante o 
pós-Guerra, mas, do ponto de vista molecular ${ }^{136}$ ela passou por intensa transformação: a Guerra Fria é caracterizada justamente pela extensão global do conflito, mas sem a declaração de guerra entre os estados. Os conflitos são agora, todos, parte de uma guerra civil, travada dentro de um mesmo território soberano, entre combatentes soberanos e não-soberanos. Nesta forma de conflito globalizado e fragmentado, o inimigo torna-se "indefinido, evanescente e espectral” (Negri, 2003, p. 77).

O resultado desta mudança em termos moleculares é o aparecimento da nova forma de soberania que não reconhece diferença entre o dentro e o fora. E, portanto, a Guerra Fria, deste ponto de vista, marca o declínio da forma nacional de soberania e o nascimento de sua forma global. Na composição atual do mundo, nenhum estado, mesmo os mais poderosos, é soberano, nem tampouco os seus adversários. E mesmo que os grandes inimigos e alvos das potências ocidentais reivindiquem a condição de estados e nações, é por meio de redes não localizáveis que eles agem e produzem sua existência.

No mundo em que, em vez de um estado-nação ou vários estados, há apenas um poder global soberano, sem um lado de fora, cada guerra é necessariamente uma guerra civil (Negri, 2003, p. 82), pois que cada conflito diz respeito a uma única sociedade que se tornou global. O soberano sempre se frustra quando tenta identificar o inimigo em um único lugar ou, como diz Negri, "única raiz diabólica” (Ibidem, p.83). O soberano está sempre ameaçado não por um inimigo externo, pois não existe mais o lado de fora da soberania, mas por um conjunto heterogêneo de tensões internas difundias em várias direções.

A nova forma da guerra global tem também como consequência a indistinção quanto aos "lados" da batalha. Diante de inimigos abstratos e que variam ao sabor das escolhas, as alianças formadas para combatê-los é igualmente expansiva e universal. Face à ameaça comunista ou mais recentemente, frente ao risco terrorista, toda a humanidade pode ser convocada a lutar.

\footnotetext{
${ }^{136}$ Como diz Negri, a "diferença entre molar e molecular não se refere somente à ordem de grandeza nem à diferença entre individual e coletivo. Ambos os termos, molecular e molar, indicam coletividades sociais: aludem a dois tipos de agregação e população. Molar se refere a amplos agregados ou grupos estatísticos que constituem, mediante processos de integração e representação, um conjunto coeso e unitário. Molecular, por sua vez, designa micromultiplicidades, ou melhor, singularidades que formam constelações ou redes nãohomogêneas" (Negri, 2003, p. 75).
} 
O conceito de "guerra justa” volta para legitimar a violência contra o inimigo selecionado e universalizar a guerra como se não estivessem ligadas a interesses particulares. E para isso, inclui-se o (suposto) interesse de toda a humanidade. E com o conceito de guerra justa, renova-se o conceito de mal absoluto. Apresentar o inimigo como encarnação do mal serve para torna-lo absoluto, assim como a guerra contra ele.

\section{4}

\section{Violência legítima e o paradigma da segurança}

Neste contexto de guerra global e de renovação do conceito de guerra justa, o terrorismo surge como paradigma de insegurança mundial e reconfigura as forças de segurança e as próprias leis. O terrorismo torna-se o próprio campo das lutas. A dificuldade em estabelecer uma definição satisfatória de "terrorismo” é, segundo Hardt e Negri (2005), consequência direta da dificuldade em estabelecer um conceito adequado de "violência legítima”. O declínio do monopólio da violência legítima por parte do Estado-Nação trouxe de volta questões inquietantes. Se a violência do Estado deixou de ser considerada legítima a priori, com base em suas próprias estruturas legais, qual o fundamento que pode legitimá-la hoje?

Como avaliar se a Al-Qaeda tem a mesma legitimidade que os militares americanos para utilizar a violência? Como comparar a violência do governo iugoslavo contra parte de sua população e a ação dos Estados Unidos no encarceramento e execução de segmentos de seu povo? Quando nenhuma forma de violência parecer ser passível de legitimação, então toda violência pode ser considerada terrorismo, dependendo de quem defina alguns de seus elementos centrais: governo legítimo, direitos humanos e normas de guerra (Hardt e Negri, 2005, p. 51). Para muitos analistas, a violência é legítima quando sua fundamentação é moral e justa, mas ilegítima se sua fundamentação é imoral e injusta.

Cada vez mais, o direito internacional se mostra em declínio, sendo aos poucos substituído por uma formal global de direito. No final das contas, a violência só pode ser legitimada a posteriori, de acordo com seus resultados. A princípio, parece que a violência do mais forte é automaticamente legitimada e a 
do fraco, imediatamente qualificada de terrorismo. Contudo, a lógica da legitimação está mais ligada aos efeitos da violência. É o restabelecimento da atual ordem global que legitima retroativamente o uso da violência.

A primeira Guerra do Golfo foi legitimada com base no direito internacional, com a justificativa de restabelecer a soberania do Kuait. A segunda guerra do Golfo era uma ação preventiva, que invocou a legitimação exclusivamente com base em seus resultados. Todo poder militar e policial será legítimo na medida em que se mostra eficaz para manter a ordem global. O inimigo é desconhecido e invisível, porém, está sempre presente, de forma a justificar a presença da força de guerra (Ibidem, pág. 56).

A guerra caminha em duas direções opostas, mas não contraditórias: por um lado, alçada a níveis absolutos, ontológicos, em razão das tecnologias de destruição total, por outro, ela é reduzida a formas de ação policial. Não são contraditórias porque embora a guerra tenha se reduzido à ação policial, ela não perde sua dimensão ontológica. O recrudescimento da função policial preserva a ameaça de genocídio e de aniquilação absoluta. O principal indício do novo caráter ativo e constituinte da guerra é a transição da política de “defesa” para a de “segurança” promovida principalmente pelo governo estadunidense depois dos ataques de setembro de 2001.

A violência da guerra não foi atenuada, mas ampliada. A vida cotidiana e o funcionamento normal do poder são permeados pela ameaça da violência da guerra. A guerra se tornou o regime de biopoder, uma forma de governo que pretende não somente controlar a população, mas produzir e reproduzir todos os aspectos da vida social. E se a guerra contra as drogas ou a guerra contra o terrorismo revelam de modo mais explicito o caráter violento do biopoder, a guerra contra a pobreza, por exemplo, dissimula a violência e a arbitrariedade na forma de atos de gestão.

Em certo sentido, a guerra é hoje menos do que foi no período moderno, mas, em outro sentido, é muito mais. Especialmente se atentamos à sua capacidade de produção do social. Ela produz morte, dor, mas também formas de vida e formas de relação. E inclusive ordens jurídicas: a possibilidade de tortura, de detenções arbitrárias, confinamentos, fronteiras, exceções contínuas.

$\mathrm{Na}$ anunciada guerra permanente contra o terrorismo, fica claro que a guerra se estende a toda parte do mundo e por tempo indefinido. De acordo com esta 
perspectiva, a manutenção da "ordem social” não pode ter fim nem limites e envolverá, tanto quanto o necessário, o exercício da violência, em nome da preservação de vidas. A guerra não tem fim e não se pode vencer.

No Brasil, a relação entre guerra de alta intensidade e baixa intensidade, ou também entre guerra e democracia, ganha outro aspecto. A guerra de alta intensidade pode acontecer dentro da cidade, contra os cidadãos eleitos como inimigos. A presença militar brasileira no Haiti é ilustração disso: as intervenções nas favelas do Rio de Janeiro foram, ao mesmo tempo, aprendizados para a “pacificação” no Haiti e foram “aprimoradas” após a experiência internacional.

O poder político soberano, no entanto, não deve chegar realmente à pura produção de morte, sob o risco de eliminar a vida que administra e que lhe serve como fundamento. Se a tortura pode ser usada como estratégia de contenção e controle, as armas de destruição são apenas meios para, sob ameaça, manter estável a tensão entre os estados e os eventuais conflitos.

Foucault já advertia que o poder não se resume a uma única e exclusiva concepção negativa ou de pura repressão; ao contrário, como ele explica, a dominação capitalista não seria capaz de se manter baseada apenas na repressão (Foucault, 2004, p.XV). A hipótese não repressiva, presente em Vontade do Saber, também foi considerada por Deleuze e Guatarri em sua elaboração de uma concepção de poder que passa pelo desejo (em Anti-Édipo). O poder, para Foucault, não apenas está situado no nível geral e amplo das relações, como ele ainda apresenta uma dimensão produtiva.

O poder produz positividade. E seu interesse primeiro não é “expulsar os homens da vida social, impedir o exercício de suas atividades, e sim gerir a vida dos homens, controla-los em suas ações, para que seja possível e viável utilizá-los ao máximo, aproveitando suas potencialidades” (Ibidem, p.XVI). .

Considerando que o poder possui uma dimensão de positividade (produção) e que a guerra não é uma exceção, mas um estado permanente (de controle), o exercício do biopoder soberano não pode significar ameaça às suas estruturas, nem mesmo uma força de desequilíbrio; ao contrário, o poder se pretende como dispositivo de estabilização da atual ordem global, o que inclui a preservação e a reprodução da vida e da capacidade de produção dos indivíduos.

Num mundo onde não há mais lado de fora, a guerra e sempre interna e, desta forma, sempre menos guerra e cada vez mais polícia (Negri, 2003, pág. 
189). Os súditos fazem parte do poder, na medida em que o poder não é outra coisa que não uma relação e, por isso, sua destruição seria insensata - seria o suicídio do poder.

O que verdadeiramente define a soberania do biopoder é sua capacidade de produzir subjetividade. Deste ponto de vista, ela não é poder puramente destrutivo, mas poder de ordenamento e de hierarquização. A guerra é longa, infinita e difusa, mas, por outro lado, seletiva e definidora de espaços e limites. E ao contrário do que se pensava sobre a guerra e a paz no mundo moderno, a ordem não é produto que nasce ao fim da guerra, mas é através da promoção indefinida a guerra se obtém a ordem.

O poder soberano se sustenta apenas se preserva a vida dos súditos e a sua capacidade de produção e consumo. Destruir a vida dos súditos implica em destruir a si mesmo e por isso, a guerra global não leva apenas à morte. Ao contrário, é a criação e regulação da vida que interessa ao regime. A redução da guerra ao exercício de polícia, ou à forma de guerra civil, intervenção ou conflito, não nega o caráter ontológico da guerra, mas, ao contrário, o exaspera, já que se torna evidente seu papel de organizadora de subjetividade.

A guerra contra o terrorismo e mesmo a guerra contra as drogas são parte de um regime cujos investimentos estão centrados principalmente no controle social, justamente no período de transição do estado de bem-estar social para o estado de guerra, marcado pelo espírito de uma sociedade de tolerância zero, em que as liberdades civis são permanentemente restringidas, ao mesmo tempo em que aumenta o encarceramento dos mais pobres (Hardt e Negri, 2005, p. 39).

No contexto desta guerra generalizada, em que a paz nem sequer pode ser sonhada, a democracia torna-se um conceito cada vez mais flexibilizado. A rigor, a guerra exige apenas hierarquia e obediência e, assim, a suspensão parcial ou total, dissimulada ou explícita, da participação dos sujeitos. A suspensão da democracia não é uma exceção, mas é a regra.

\section{5}

\section{Estados de violência e a segurança dos viventes}

Frédéric Gros (2009) dá a esta nova configuração mundial de insegurança generalizada o nome de "estados de violência”. Em sintonia com Hardt e Negri, 
Gros afirma que o fim da era nuclear não trouxe a paz. Ao contrário, na sequência da "queda do muro", surgiram novas formas de violência: intervenção e segurança; as grandes potências deixaram de fazer a guerra, mas adotaram a intervenção. E se antes o intervencionismo era considerado um escândalo, e por isso acontecia em segredo, hoje, a guerra é que seria um escândalo. E diferentemente do que ocorria antes nas intervenções secretas, agora ela não é propriamente militar, mas, antes, é policial.

A intervenção significa impor a ordem, neutralizar os fatores de perturbação, prender os criminosos. O interventor não se mostra como um ator do mesmo nível daquele em que intervém, mas como agente da ordem mundial, representante de uma comunidade de valores e de ordem. Neste novo mundo em que a guerra não tem mais lugar, a intervenção não é outra coisa se não a ponta armada de um dispositivo geral de segurança.

Se a guerra defendia uma pátria, um povo e sua ideologia, a guerra, na forma de "segurança", protege tão somente os indivíduos vivos. Por isso, assim como o conceito de intervenção, a ideia de segurança não é propriamente militar. Além de garantir proteção contra atos violentos, a segurança significa também proteção contra agressões que ameaçam sua integridade: epidemias, fome, doenças, etc. Como diz Gros, “a segurança como regulação dos estados de violência supõe levar em conta uma trama única comportando todos os riscos incorridos pelo vivente, do vírus ao atentado terrorista” (Gros, 2009, p. 245).

A segurança é mais do que a ausência de hostilidades declaradas entre nações. Ela designa um processo ininterrupto de proteção dos indivíduos, em que o risco jamais é absolutamente redutível. O risco é o limite insuperável em que vivem os indivíduos. E a segurança é tanto mais eficaz, quanto mais puder ser internalizada, assumida por cada um dos indivíduos. Citando Foucault, ele afirma que toda segurança é uma biopolítica.

A polícia e o exército, a diplomacia e os serviços privados de segurança, a medicina e as entidades humanitárias, todos se dirigem a um mesmo esforço de segurança do indivíduo. E para tanto, a segurança assume a retórica dos direitos do homem, mas de uma maneira diferente, pois em lugar do sujeito de direito, surge o indivíduo vivo.

Visto da perspectiva de vivente, o indivíduo é menos um sujeito que reivindica direitos do que um ser com pontos de vulnerabilidade a superar. Neste 
sentido, há uma continuidade de viventes e, portanto, uma continuidade necessária de proteção, desde o policial até o militar, do risco alimentar ao risco terrorista, etc. Continuidades que são permanentemente integradas por fluxos de imagens e sublinhadas pela solidariedade dos espectadores, formando todos uma grande comunidade de vítimas. Os estados de violência não estão em oposição às guerras, mas antes, se organizam de acordo com linhas indiferentes às antigas divisões. O sistema de segurança, portanto, constitui um princípio de regulação interna e contínuo.

Ao mesmo tempo em que a guerra torna-se global e cotidiana, as imagens e narrativas sobre a violência passam a dar cada vez mais importância às vítimas, ainda que elas -- salvo algumas exceções, como o caso de Aylan Kurdi - nunca tenham rosto em particular. Distinguem-se apenas as perdas, entre as pesadas ou leves, aceitáveis ou excessivas. Produz-se uma nova economia moral em consonância com a imagem fragmentada das guerras.

Não há narrativa que possa distinguir sofrimentos, que possa discriminar a justiça das causas ou criar comunidade. O conflito nada mais é do que um homicídio e não há como explicar porque a violência atingiu logo estes que choram diante das câmeras. Não há contexto, explicações, por vezes há os vilões, mas, em geral, há, sobretudo, as vítimas sobreviventes. Tem valor apenas o escândalo do sofrimento individualizado das vítimas, através de imagens que embotam a inteligência e desestimulam qualquer tentativa de explicação ou justificação. Restam apenas as imagens de sofrimento.

A guerra tornava visível a existência das cidades, dos impérios e dos Estados, como "unidades políticas" que eram o palco de seu acontecimento. E, ao mesmo tempo em que lhes dava consistência, revelava a precariedade das comunidades históricas. No atual de estado de guerra global (Hardt e Negri, 2005) ou de estados de violência (Gros, 2009), a regulação é feita por dispositivos de segurança que valorizam principalmente a fragilidade do indivíduo, dando à violência o sentido de vulnerabilidade individual, referente a uma causa externa. Assim, há uma continuidade entre os atos terroristas, as epidemias ou as catástrofes naturais, assim como entre os conflitos civis e os crimes de direito comum.

O "migrante" é anunciado como crise, o que significa, no limite, a virtual ameaça que vem de fora para corromper a segurança e a estabilidade interna. E 
quando associam à sua figura outras qualidades de perigo e risco - como o “fundamentalista islâmico”, “terrorista”, “tráfico de pessoas”, etc -- ele justifica a retórica da crise e a explicitação, em seguida, de todo o aparato de exceção. Não importa que esteja ele mesmo fugindo dos terroristas ou esteja buscando protegerse do terror que o seu próprio estado lhe inflige. Ele se torna apenas a justificativa para a ampliação dos investimentos em segurança e repressão nas fronteiras e para seu próprio encarceramento em subordinação, medo e culpa.

Não se trata, porém, apenas de aumentar a possibilidade de repressão, ampliar o rol de tipos penais e o número de sujeitos encarceráveis. A mesma governabilidade que investe nos conflitos e nos massacres e que exponencialmente cria centros de detenção para migrantes e refugiados, produz também conhecimento sobre estas figuras, isto é, o "saber” e a “verdade” sobre suas motivações, suas escolhas e sobre suas estratégias. E também sobre como devemos nos sentir diante deles.

Todo o esforço feito pelos ativistas e pelas organizações de direitos humanos em nos tornar sensíveis diante dos problemas dos refugiados, ao final das contas, lamentavelmente acentua a mesma lógica de distinção que o sistema global de refúgio faz operar, baseada na imagem fragmentada das guerras e na piedade impotente. A definição do refugiado é forjada na distinção em relação ao migrante e sobre esta distinção é sempre o conceito de voluntariedade que está em questão para dizer quem foi obrigado a fugir e quem escolheu deixar seu país.

E será a coerção da fuga que permitirá a criação da imagem da vitimização e da inocência. E sobre elas, todas as boas intenções investirão seus desejos para aprofundar ainda mais as injustiças e iniquidades. O poder possui habilidades para apostar na afirmação e no desejo e há tempos não se trata mais de dizer “não”. É na afirmação que ele opera e será condescendência, pela afirmação contínua da vítima inocente e frágil, coagida a fugir contra sua vontade, que se operará o confinamento das subjetividades e das relações.

E ainda que a produção desta distinção não se faça sem resistências, ela soterra não apenas todas as nuances, mas coloca todos os sujeitos que fogem sob chantagem. A operação de distinção opera pela afirmação e, portanto, nem sequer se localiza exclusivamente nos supostos circuitos do estado. Nada está excluído do poder, nem as almas dos “súditos”, nem seus desejos e boas intenções. 


\section{6}

\section{Cálculo dos riscos e controle dos fluxos}

De um lado, a guerra é o que ocorre hoje na Síria e em partes da República Democrática do Congo: tropas, mísseis, blindados e contagem de corpos. Mesmo dentro do Congo, no entanto, a guerra ganha outras dimensões: perseguição política, corrupção sistêmica, violência sexual contra mulheres e meninas, democracia precária, etc. Conflitos fragmentados, esparsos e por vezes longos e continuados, por vezes, pontuais. Não há uma maneira simples de explicar a guerra em que se transformou o próprio país. Há resquícios das lutas por independência e autonomia, rivalidades étnicas e tribais, junto com disputas regionais entre países africanos, principalmente em torno da riqueza de recursos minerais. Um sem número de eventos que não se resumem à política interna da soberania do país.

Dentro da perspectiva humanitária do refúgio, importaria distinguir as vítimas em risco de "fundado temor", os vulneráveis e os deslocados, para que recebam a devida assistência ou sejam amparadas através dos protocolos específicos. Quando, no entanto, os "refugiados” decidem fugir em direção ao continente dos “direitos do homem”, porque escolheram viver, é declarada contra eles uma guerra, em outras modulações, mas tão selvagem e cruel quanto qualquer outra guerra.

Evidentemente, a guerra movida contra os “migrantes” terá sucesso em impedi-los de cruzar as fronteiras e, em especial, impor medo a outros que estejam a caminho. De outra parte, porém, o regime soberano atual sempre encontrou modos de recompor as estruturas de ordem: não se trata apenas de fechar hermeticamente as fronteiras, mas estabelecer sistema de diques para produzir, em última instância, um processo ativo de inclusão do trabalho e da cidadania dos migrantes através da ilegalidade ou submissão ${ }^{137}$.

137 MEZZADRA, Sandro. "Capitalismo, Migraciones y luchas sociales. La mirada de la autonomia”. Nueva Sociedad, 237, janeiro-fevereiro de 2012. 


\section{6}

\section{A guerra contra os refugiados.}

"Nosso desejo de fugir é mil vezes mais forte do que a vontade que eles têm de nos impedir. Por isso, nunca serão capazes de nos parar".

Charly Kongo ${ }^{138}$

"Essa reivindicação de humanidade como relação é, afinal, aquilo que entendemos ou deveríamos entende por libertação. Os escravos tão bem o souberam, ninguém a concede; é preciso rugir, como os animais, para consegui-la” ${ }^{139}$.

Silvio Pedrosa

A crise dos refugiados, como se poderá constatar, não é uma crise europeia: há cerca de 14 milhões de refugiados e mais de 30 milhões de deslocados internos espalhados pelo Oriente Médio e pela África Subsaariana. Três países muçulmanos acolheram 30\% dos refugiados do mundo: Turquia, Líbano e Paquistão. Enquanto isso, aproximadamente um milhão de pessoas tentaram refúgio na Europa, ao custo de aproximadamente 3.700 vidas perdidas no Mar Mediterrâneo, somente em 2015. Em termos de impacto econômico, são os países mais pobres que sofrem: a Etiópia é o país mais afetado economicamente pela chegada dos refugiados. Em seguida, estão Paquistão, Uganda, República Democrática do Congo, Chade e Quênia. A “crise” dos refugiados é, sobretudo, uma crise para os países mais pobres ${ }^{140}$.

\footnotetext{
138 Jovem refugiado congolês que vive no Brasil.

139 Fragmento de texto publicado por Silvio Pedrosa, educador da rede pública, no Facebook. (https://www.facebook.com/shgpedrosa/posts/1057524690926969)

140 De acordo com o relatório oficial do ACNUR “Mid Year Trends - June 2015”. (Disponível em http://www.unhcr.org/56701b969.html) (Último acesso em 07/04/2016).
} 


\section{1}

\section{A crise dentre as crises: os refugiados na África}

Sob o efeito de uma das maiores secas das últimas três décadas, a Etiópia tem cerca de 400 mil crianças em situação de má nutrição aguda e mais de 10 milhões de pessoas carentes de ajuda alimentar ${ }^{141}$. O governo do país calcula que em 2016, 102 milhões de pessoas vão precisar de assistência humanitária. Agravada pelo "El Niño”, a seca também afetou as colheitas e provocou a morte de 500 mil animais que seriam usados para alimentação. As pessoas são obrigadas a se deslocar por grandes distâncias - andando por dias - para conseguir água ${ }^{142}$.

Ainda sobre o continente africano, a longa crise humanitária na República Democrática do Congo deslocou mais de um milhão de pessoas apenas para os países vizinhos. Nos anos 1990, cerca de 300 mil congoleses fugiram para Angola, Burundi, República Central Africana, República do Congo, Ruanda, Sudão (e onde hoje é Sudão do Sul), Tanzânia, Uganda e Zâmbia. Nos anos 2000, a diáspora congolesa ultrapassou 1,2 milhões de pessoas, somente no continente $^{143}$. África do Sul e Angola receberam mais da metade dos congoleses na diáspora durante os anos 2000. E há ainda os deslocados internos, que, em 2008 chegavam a 3,8 milhões de pessoas e em 2015 eram cerca de 2,8 milhões.

Ao mesmo tempo, a República Democrática do Congo recebeu, durante os anos 1990, cerca de 650 mil pessoas, algumas delas fugindo do massacre em Ruanda. Em março de 2016, cerca de 250 mil ruandeses ainda viviam no Congo e a eles somaram-se mais refugiados: mais de 100 mil pessoas fugindo da recente

\footnotetext{
141 “Ethiopia drought 'as bad for children as Syria's war'. Al Jazeera. Charles Stratford. 17/01/2016. (Disponível em http://www.aljazeera.com/news/2016/01/ethiopia-drought-prompts-globalappeals-aid-160117143110259.html). (Último acesso em 26/01/2016)”.

${ }^{142}$ Informações disponíveis na imprensa internacional: "Hunger crisis in Ethiopia worsens amid drought”.BBC. 31/01/2016. (Disponível em http://www.bbc.com/news/world-africa-35455053); e em sites de organizações humanitárias: "Ethiopia food crisis”. Oxfam International. (Disponível em https://www.oxfam.org/en/emergencies/ethiopia-food-crisis) e "Water in crisis - Ethiopia". The Water Project. (Disponível em https://thewaterproject.org/water-in-crisis-ethiopia) (Último acesso em 17/04/2016).

143 "Democratic Republic f the Congo: A migration history marked by crises and restrictions". Migration Policy Instituto. 20/04/2016. Marie-Laurence Flaxaus e Bruno Schoumaker. (disponível em http://www.migrationpolicy.org/article/democratic-republic-congo-migration-history-markedcrises-and-restrictions) (Último acesso em 13/05/2016).
} 


\begin{abstract}
guerra na República Centro Africana ${ }^{144}$, 25 mil fugindo do conflito no Burundi ${ }^{145}$, sem contar quase 500 mil angolanos que fugiam da guerra civil ${ }^{146}$.
\end{abstract}

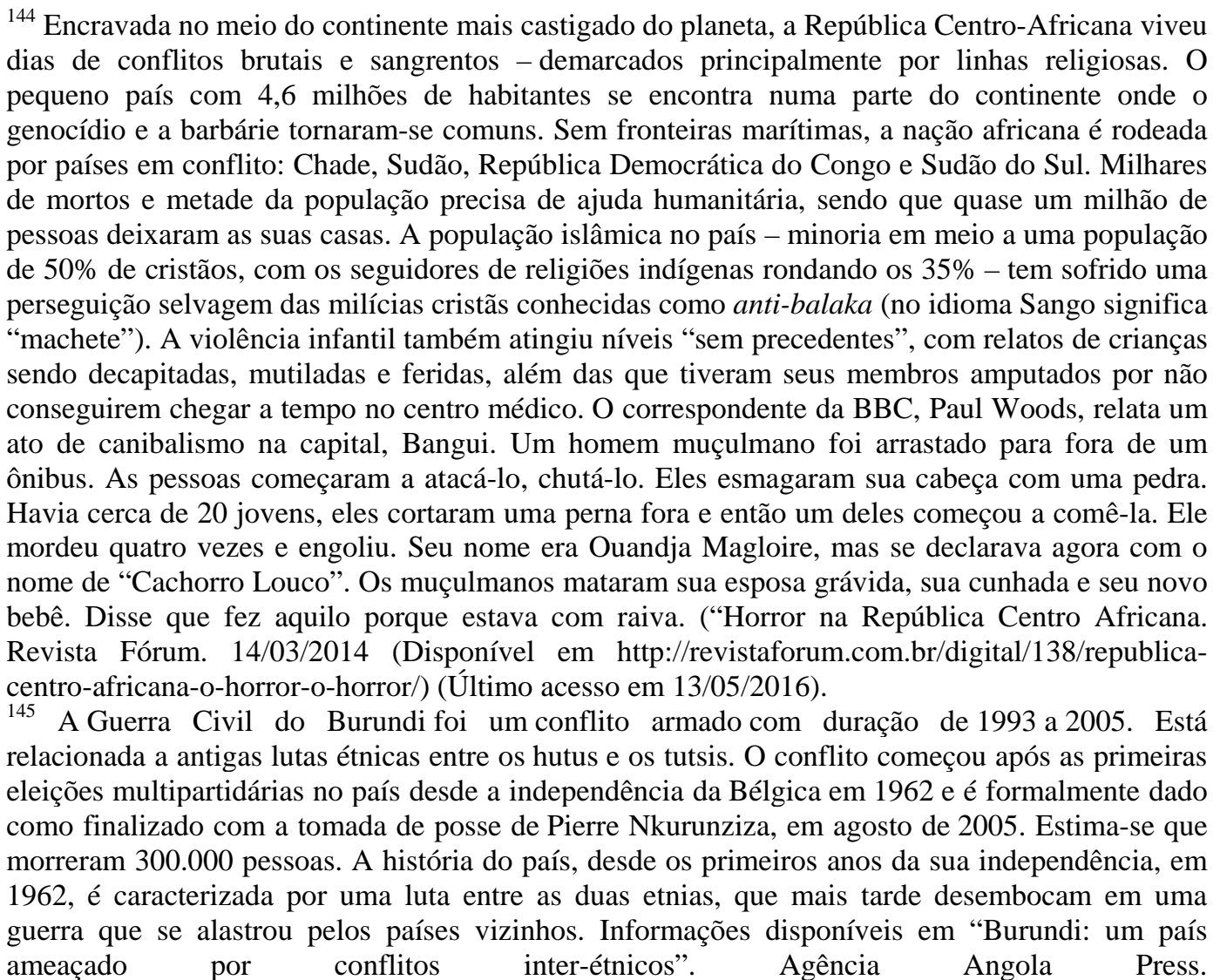
ameaçado por conflitos inter-étnicos”. Agência Angola
(http://www.portalangop.co.ao/angola/pt_pt/noticias/africa/2015/4/20/Burundi-historia-paismarcada-por-conflitos-inter-etnicos,46072c7c-ae85-484b-8f50-9238d5c222fc.html) (último acesso em 13/05/2016).

${ }^{146}$ Logo após a luta por sua independência, Angola passou por um longo período de guerra civil que teve início em 1975 e continuou, com alguns intervalos, até 2002. A guerra civil angolana foi essencialmente uma luta pelo poder entre dois antigos movimentos de libertação, o Movimento Popular de Libertação de Angola (MPLA) e a União Nacional para a Independência Total de Angola (UNITA). A guerra serviu como uma as frentes de hostilidade no contexto de Guerra Fria, com forte envolvimento internacional: União Soviética, Cuba, África do Sul e Estados Unidos. No dia 4 de abril de 2002 a paz chegou a Angola com a assinatura do acordo de Luanda entre o governo do Movimento Popular para a Libertação de Angola (MPLA) MPLA e a União Nacional pela Independência Total de Angola (UNITA). As duas formações políticas com mais influência no país pousaram as armas, pondo, assim, fim a 27 anos de uma guerra civil que causou pelo menos 500 mil mortos e mais de dois milhões de refugiados. A seguir à paz, Angola viveu um "boom" económico graças ao petróleo, atingindo um crescimento de mais de $20 \%$ em 2005 e em 2007. Mas apesar deste crescimento, muitos angolanos continuam até hoje a viver na pobreza. ("Cronologia 1974-2002: das independências ao fim da guerra em Moçambiique e Angola”. DW. Disponível em http://www.dw.com/pt/cronologia-1974-2002-das-independencias-ao-fim-daguerra-em-moc-e-angola/a-17280940) (último acesso em 14/05/2016). 


\section{2}

\section{América Latina, guerra e instabilidade}

Na América Latina, com mais de meio século de duração ${ }^{147}$, o conflito armado colombiano provocou o deslocamento de milhões de pessoas e colocou o país dentre os cinco mais violentos do mundo ${ }^{148}$. Além do saldo de 40 mil mortos, em sua maior parte civis, a Colômbia está entre os países com maior número de deslocados internos no mundo. Com 6,7 milhões de pessoas deslocadas -- o que significa $13 \%$ da população -- é a segunda maior crise do mundo depois da Síria ${ }^{149}$.

Cerca de 360 mil colombianos foram reconhecidos como refugiados em outros países, principalmente no Equador, o pais da América Latina com maior número de refugiados reconhecidos: 54.800 pessoas, fora os que ainda não tiveram uma decisão formal de reconhecimento. De acordo com relatórios de 2013, o país contabilizou 160 mil pedidos de refúgio desde o ano 2000, dos quais 98\% são colombianos. Em média, mil pessoas entravam no país a cada mês para pedir refúgio.

Dentre estes, 60\% estão vivendo em regiões extremamente pobres e os demais vivem em regiões isoladas, com frágil infraestrutura ${ }^{150}$, vulneráveis à ação

${ }^{147}$ O conflito colombiano iniciou aproximadamente em 1964 ou 1966, como uma guerra de baixa intensidade entre o governo colombiano, os grupos paramilitares, os traficantes e os guerrilheiros de esquerda, como as Forças Armadas Revolucionárias da Colômbia e o Exército de Libertação Nacional (ELN), lutando entre si para aumentar sua influência em território colombiano. É historicamente enraizada no conflito conhecido como La Violencia, que foi desencadeado pelo assassinato do líder político populista Jorge Eliécer Gaitán em1948, na sequência da forte repressão anticomunista apoiada pelos Estados Unidos na área rural da Colômbia na década de 1960. O conflito, portanto, tem antecedentes antigos, incluindo a luta dos camponeses e do Partido Comunista Colombiano e por isso muitos dizem que ele não pode está limitado aos 50 anos de guerra entre os principais grupos. Sobre o conflito colombiano, informações em "Acordo entre Colômbia e FARC pode por fim ao mais longo conflit interno no Ocidente”. BBC Brasil, 23/09/2015 (disponível em

148 “Quem é quem no conflito armado da Colômbia”. BBC Brasil. 10/07/2012. (Disponível em http://www.bbc.com/portuguese/noticias/2012/07/120605_colombia_quem_ac_lf.shtml) (Último acesso em 14/05/2016) e sobre os antecedentes do conflito há informações em "Manuel Marulanda, top commander of Colombia's largest guerrilha group, is dead”. The New York Times, 26/05/2008 (Disponível em http://www.nytimes.com/2008/05/26/world/americas/26marulanda.html?_r=0) (Último acesso em 28/05/2016).

149 “ACNUR pede que refugiados sejam ouvidos em negociações de paz na Colômbia”. ONUBR Nações Unidas no Brasil. 12/04/2016 (Disponível em https://nacoesunidas.org/acnur-pede-querefugiados-sejam-ouvidos-em-negociacoes-de-paz-na-colombia/) (Último acesso em 14/05/2016)

150 "UNHCR Global Appeal 2014-2015. Ecuador”. (Disponível em http://www.unhcr.org/528a0a370.html) (Último acesso em 14/05/2016). 
de guerrilheiros, paramilitares e às arbitrariedades das forças de segurança do país. Dados oficiais citados pela Acnur indicam que 74\% dos refugiados internos são mulheres e crianças -- para quem o abandono da casa muitas vezes significa o fim dos estudos. Segundo a agência, estima-se que apenas uma em oito crianças que estavam na escola volta a estudar depois que se "refugiam" em outra parte do país. As meninas também ficam mais expostas à exploração sexual ${ }^{151}$.

Na Venezuela, o escritório do ACNUR estima que existem cerca de 200 mil colombianos buscando proteção, mas, segundo a Comissão Nacional de Refugiados do país, estão registrados apenas 14.723 solicitantes de refúgio e 2.900 refugiados $^{152}$. Em agosto de 2015, no entanto, o presidente da Venezuela determinou o fechamento da fronteira com Colômbia, no estado de Táchira, após uma crise diplomática. Segundo a versão oficial do presidente, o fechamento da fronteira está ligado à repressão de paramilitares e criminosos e contará com três mil militares. Uma semana antes, outro trecho da fronteira havia sido fechado, e mil colombianos foram deportados do país, sob o pretexto de "segurança". Oficialmente, o governo não admite que existam refugiados ou solicitantes dentre os deportados, mas ninguém foi capaz de confirmar.

O presidente Maduro adotou as medidas logo depois de um ataque que deixou três militares venezuelanos feridos. Ao mesmo tempo, ele acusa o contrabando na fronteira como um dos motivos de desestabilização de seu governo. Segundo o presidente, paramilitares estão envolvidos com partidários de direita para atacar e desestabilizar o seu governo. Apesar das manifestações do Alto Comissariado da ONU para os Direitos Humanos, a decisão não foi revogada $^{153}$. A crise política e econômica na Venezuela, que tem os piores índices de inflação do mundo e sofre com falta de medicamentos e desabastecimento de mercadorias básicas, é apontado com principal motivo para a crise na fronteira. O governo do Panamá também decidiu fechar a fronteira com a Colômbia, como forma de reduzir o fluxo de migrantes. Sob a justificativa de falta de recursos, o

151 “Colômbia é o segundo país com mais refugiados internos, diz ONU”. Folha de São Paulo. 19/04/2006. (Disponível em http://www1.folha.uol.com.br/folha/bbc/ult272u52655.shtml) (Último acesso em 14/05/2016).

${ }^{152}$ « Al redor de 200.000 colombianos se encuentran refugiados en Venezuela ». El Espectador. 17/05/2016 (Disponível em http://www.elespectador.com/noticias/politica/alrededor-de-200000colombianos-se-encuentran-refugiado-articulo-208520) (Último acesso em 21/05/2016).

153 «Maduro anuncia fechamento de novo setor na fronteira Venezuela-Colômbia” .G1. 28/08/2015. (Disponível em http://g1.globo.com/mundo/noticia/2015/08/maduro-anunciafechamento-de-novo-setor-na-fronteira-venezuela-colombia.html) (Último acesso em 21/05/2016). 
governo atendeu aos pedidos do município de Acandí, onde cerca de 50 pessoas chegam diariamente e determinou o fechamento ${ }^{154}$.

\section{3}

\section{Oriente Médio e o conflito sírio}

No Oriente Médio, por sua vez, a crise ganhou dimensões sem precedentes. Na Jordânia, país com oito milhões de habitantes, já são aproximadamente 1,2 milhão de refugiados que chegaram em massa ${ }^{155}$. Naquele país, a propósito, foi criado o campo de Zaatari, que abriga cerca de 80 mil refugiados ${ }^{156}$. A maior parte dos refugiados, porém, vive integrada nas comunidades enquanto aproximadamente 15\% vive em campos. Em 2015, as autoridades reiteradamente impediam a entrada de refugiados sírios ou os mantinham em "zonas de trânsito", o que, na prática, significava abriga-los em regiões desérticas, ao longo da fronteira com a Síria ${ }^{157}$. No Líbano, há mais de um milhão de sírios oficialmente registrados como refugiados ${ }^{158}$. Obrigados a fazer prova de que estão amparados por um “patrocinador”, os refugiados são vulneráveis à exploração no trabalho.

Os recursos disponíveis para as cidades da Jordânia, incluindo a capital Amã, não são suficientes, mesmo com ajuda internacional. Cerca de meio milhão de refugiados corre o risco de ficar sem alimento, desde que a agência da ONU anunciou a sua incapacidade financeira ${ }^{159}$. Refugiados sírios no Líbano também

154 «Colombia teme crisis migratoria por cierre de la frontera de Panamá”. La Estrella de Panamá 11/05/2016. (Disponível em http://laestrella.com.pa/internacional/america/colombia-teme-crisismigratoria-cierre-frontera-panama/23939443) (Último acesso em 21/05/2016).

155 "La Jordanie demande l'aide de l'EU”. EurActiv. James Crisp. (Disponível em http://www.euractiv.fr/sections/leurope-dans-le-monde/la-jordanie-demande-laide-de-lue-321129). ～(Último acesso em 26/01/2016).

${ }^{156}$ United Nations High Commissioner for Refugees (UNHCR). "UNHCR data Portal. UNHCR Syria Regional Refugee Response”. (Último acesso em 26/04/2016).

157 “Jordan:Syrians held in desert face crisis”. Human Rights Watch. 08/12/2015 (Disponível em https://www.hrw.org/news/2015/12/08/jordan-syrians-held-desert-face-crisis) (Último acesso em 29/04/2016).

158 “Lebanon: Residency rules put Syrians at risk”. Human Rights Watch. 12/01/2016 (Disponível em https://www.hrw.org/news/2016/01/12/lebanon-residency-rules-put-syrians-risk); “Syrian refugees in Lebanon live in fear of deportation”. Al Jazeera. Olivia Alabaster. 22/01/2016. (Disponível em http://www.aljazeera.com/news/2016/01/syrian-refugees-lebanon-live-feardeportation-160117102350730.html). (Último acesso em 26/01/2016).

159 "Half a million Syrian refugees to stop receiving food aid when the money runs out next month". The Independent. 01/07/2015. (Disponível em http://www.independent.co.uk/news/world/middle-east/half-a-million-syrian-refugees-to-stopreceiving-food-aid-when-the-money-runs-out-next-month-10358632.html) (Último acesso em 26/04/2016). 
foram afetados pelos cortes na ajuda, assim como os somalis e sudaneses acolhidos no Quênia ${ }^{160}$.

\section{4}

\section{A exceção como paradigma: a crise dos refugiados na Europa}

No Egito, ao final de 2013, cerca de 300 sírios foram detidos, depois que 1.500 tentavam migrar para a Europa em barcos. A falta de segurança - inclusive econômica - e a crescente xenofobia no Egito foi o principal incentivo para que os refugiados buscassem proteção em outros países ${ }^{161}$. As autoridades egípcias querem processar os refugiados sírios sob acusação de imigração ilegal, mas a maior preocupação das entidades de proteção a direitos humanos era a condição a que estavam submetidos os refugiados: os alojamentos da delegacia onde eles estão detidos eram tão apertados que as pessoas estavam acomodadas umas sobre as outras ou mesmo em pé, dividindo um único banheiro e um só chuveiro.

A fim de evitar a detenção indefinida, alguns dos refugiados concordaram em assinar declarações comprometendo-se a deixar o país por conta própria. Forças militares egípcias chegaram a disparar contra um barco que transportava entre 170 a 200 sírios e palestinos que vivem na Síria, matando duas pessoas. Pouco depois deste incidente, um barco com sírios afundou, matando 12 pessoas e deixando muitos desaparecidos, principalmente idosos e crianças ${ }^{162}$.

Na Turquia, depois do acordo para "terceirização” das fronteiras europeias, há registros de refugiados baleados e espancados, incluindo sírios que fugiam de bombardeios. Relatório da "Human Rights Watch" trata da morte de cinco pessoas, incluindo uma criança, além de 14 pessoas gravemente feridas, em razão da violência dos guardas de fronteira ${ }^{163}$. O relatório, publicado em maio de 2016,

160 "UN agencies 'broke and failing' in face of ever-growing refugee crisis”. The Guardian. 06/09/2015. Disponível em http://www.theguardian.com/world/2015/sep/06/refugee-crisis-unagencies-broke-failing) (Último acesso em 26/04/2016).

161 "Egypt: Syria refugees detained, coerced to return”. Human Rights Watch. 10/11/2013. (Disponível em https://www.hrw.org/news/2013/11/10/egypt-syria-refugees-detained-coercedreturn) (Último acesso em 29/04/2016).

162 “'We cannot live here anymore' Refugees from Syria in Egypt”. Amnesty International. 16/10/2013. (Disponível em http://www.amnestyusa.org/research/reports/we-cannot-live-hereanymore-refugees-from-syria-in-egypt) (Último acesso em 29/04/2016).

163 “Turkey: Border guards kill and injure asylum seekers”. Human Rights Watch. 10/05/2016. (Disponível em https://www.hrw.org/news/2016/05/10/turkey-border-guards-kill-and-injureasylum-seekers) (Último acesso em 13/05/2016). 
revela também que os guardas de fronteira bloquearam milhares de pessoas fugindo depois que o campo onde estavam ter sido atacado.

Além de erguer um muro e concreto com mais de 900 quilômetros de extensão na fronteira com a Síria, a Turquia tem interceptado violentamente pessoas que tentam cruzar a fronteira. Algumas foram detidas arbitrariamente e enviadas de volta. Alto-falantes instalados perto da fronteira anunciam, em árabe, que qualquer um que se aproxime poderá ser baleado.

O conflito na Síria e a crise financeira fizeram da Turquia uma passagem para a Europa por meio da Grécia, que se tornou uma brecha para a entrada de refugiados e imigrantes na Europa. Antes que a Grécia adotasse sua política de portas abertas aos refugiados, a partir, sobretudo, dos primeiros anos do governo Syriza, a situação era dramática. Dos 10 mil pedidos de refúgio feitos entre 2007 e 2011, apenas pouco mais de 1.200 conseguiram o status. Enquanto aguarda a decisão ao seu pedido, o solicitante pode ficar detido por um ano. Para os migrantes, a detenção pode se estender até 18 meses.

A despeito de onze condenações pelo Tribunal Europeu de Direitos Humanos, em razão das condições em que estão detidos os refugiados e migrantes ${ }^{164}$, a Grécia mantinha uma política abertamente violenta contra eles, incluindo detenção em condições degradantes e política de “caça” aos refugiados e migrantes. Em agosto de 2013, a polícia lançou uma caçada para capturar os refugiados e migrantes que escaparam do centro de detenção próximo a Amygdaleza, depois de uma rebelião que se iniciou quando as 1200 pessoas souberam que sua detenção se estenderia para além dos 12 meses previstos ${ }^{165}$.

No centro de detenção, protegido por cercas e arame farpado, as pessoas compartilham dormitórios (70 a 80 pessoas em cada um) e eram autorizadas a caminhar apenas duas vezes por dia. O chuveiro era disponível durante noventa minutos por dia e havia um número considerável de pessoas sofrendo com

\footnotetext{
164 “Greece: Address longstanding rights issues”. Human Rights Watch. 19/02/2015. (Disponível em https://www.hrw.org/news/2015/02/19/greece-address-longstanding-rights-issues) (Último acesso em 29/04/2016).

165 "Greece: Systematic and prolonged detention of irregular migrants and asylum-seekers provokes riot” em “Amnesty International Public Statement”. 13/08/2013. (Disponível em http://www.refworld.org/pdfid/520e0f974.pdf) (Último acesso em 29/04/2016).
} 
transtornos psíquicos, que se agravaram com as condições da detenção. Nas palavras de um dos detidos, o centro é “uma nova Guantánamo” 166.

A maioria das cerca de mil pessoas colocadas no centro foram detidas em meados de 2012, quando o governo grego lançou a operação “Zeus Xênios”, o deus da hospitalidade. O representante da Anistia Internacional, que visitou o centro junto com outras organizações de direitos humanos e também com o Comissário de Direitos Humanos do Conselho Europeu, reagiu afirmando que mal podia acreditar que estava na Europa. Um argelino colocado em detenção denunciou o triste destino da política europeia: “os gregos são estúpidos. Eles colocaram arame farpado em seu sol”.

Somente em janeiro de 2016, mais de 46 mil pessoas chegaram à Grécia: aproximadamente três mil pessoas chegavam diariamente ao país, apesar do rigoroso inverno. Dentre os que chegaram à Grécia, somente nos três primeiros dias de 2016, a grande maioria era de sírios (41\%) e afegãos (37\%) e os demais vinham o Iraque, Irã, Palestina, dentre outros países ${ }^{167}$. Dentre os que tentaram as diversas travessias marítimas até a Europa - rota entre Turquia e Grécia ou a rota entre o Norte da África e Itália -- ao menos 620 morreram. Em 2015, no mesmo período, foram $505^{168}$.

Refugiados sírios pagam cerca de US\$ 3 mil para atravessar o Mediterrâneo até chegar à Europa, valor muito maior que o custo médio de um bilhete de avião ${ }^{169}$. Não é por causa de dinheiro que os refugiados se arriscam nos barcos e não são poucos os que se arriscam: de acordo com a Organização Internacional de Migração, pelo menos 170 mil pessoas, entre migrantes e refugiados, chegaram à

\footnotetext{
166 “Imigrantes detidos na Grécia relatam abusos em ‘nova Guantánamo’”, Le Monde, 26/08/2013. (Disponível em http://www.worldcrunch.com/culture-society/a-visit-to-the-quot-greekguantanamo-quot-/immigration-asylum-detention-camp/c3s13092/ e também em http://m.noticias.uol.com.br/midiaglobal/lemonde/2013/08/26/imigrantes-detidos-na-greciarelatam-abusos-em-nova-guantanamo.htm) (Último acesso em 29/04/2016).

167 "IOM counts 3,771 migrant fatalities in Mediterranean in 2015". International Organization for Migration. (Disponível em https://www.iom.int/news/iom-counts-3771-migrant-fatalitiesmediterranean-2015) (Último acesso em 02/05/2016).

${ }^{168}$ Dados disponíveis no site da OIM (www.iom.int) (Último acesso em 19/04/2016).

169 "Want to stop refugees from dying at sea? Let them fly". Equal Times. Bruan Carter.16/09/2015. (Disponível em http://www.equaltimes.org/want-to-stop-refugees-fromdying?lang=en\#.VpppwPmLTIV). (Último acesso em 22/01/2016).
} 
Europa somente nos três primeiros meses de 2016, utilizando rotas marítimas. É um número oito vezes superior ao mesmo período do ano anterior ${ }^{170}$.

Mais de 170 morreram na travessia marítima neste breve período de um mês. Logo no começo de 2016, dois incidentes com 68 vítimas. No primeiro, Ao menos 25 pessoas, incluindo 18 crianças, morreram afogadas no Mar Egeu quando o barco em que usavam para chegar à Grécia naufragou. Dez pessoas foram resgatadas e levadas ao hospital ${ }^{171}$, mas a guarda costeira não sabe exatamente quantas pessoas havia no barco. Dias antes, 44 pessoas - a maioria mulheres e crianças -- morreram no mesmo lugar, quando dois barcos se chocaram com a costa da pequena ilha de Farmakonisi ${ }^{172}$. As autoridades gregas estimam que entre 30 a 60 pessoas estejam desaparecidas, enquanto 74 foram resgatadas $^{173}$. Desde 2000, a OIM contabiliza 40 mil fatalidades no Mediterrâneo $^{174}$.

O Mediterrâneo se tornou um enorme cemitério justamente por causa das políticas terrivelmente restritivas da Europa. A propósito, seria mais apropriado dizer que o Mediterrâneo transformou-se em uma grande "vala comum”, seguindo assim a tradição dos genocídios monumentais. A explicação para que os refugiados tenham que pagar os “coiotes” e arriscar suas vidas está em uma normativa da União Europeia que determina responsabilidades das companhias de transporte pela chegada dos refugiados.

De acordo com o artigo $3^{\circ}$ da Diretiva 2001/51/CE (“Carrier Sanctions Directive”) ${ }^{175}$, que complementa o Acordo de Schengen (1985), os Estados membros devem tomar as medidas necessárias para obrigar as empresas

170 “Mediterranean Migrant arrivals in 2016”. Internacional Organization for Migration. 01/04/2016 (Disponível em https://www.iom.int/news/mediterranean-migrant-arrivals-2016169846-deaths-620) (Último acesso em 02/05/2016).

171 “Dozens die in refugee boat disaster off Greek island”. Al Jazeera. 28/01/2016. (Disponível em http://www.aljazeera.com/news/2016/01/160128082306824.html). (Último acesso em 28/01/2016).

172 "Refugees drown as two boats capsize off Greek islands”. Al Jazeera. 23/01/2016.( Disponível em http://www.aljazeera.com/news/2016/01/refugees-drown-boats-capsize-greek-islands160122100827699.html). (Último acesso em 28/01/2016).

173 “Ao menos 44 refugiados morrem em naufrágios no Mar Egeu”. O Globo.22/01/2016. (Disponível em http://oglobo.globo.com/mundo/ao-menos-44-refugiados-morrem-em-naufragiosno-mar-egeu-18520401). (Último acesso em 25/01/2016).

${ }^{174}$ Dados disponíveis em http://migration.iom.int/europe/ (Último acesso em 05/05/2016).

${ }^{175}$ Council Directive 2001/51/, of 28 June 2001, supplementing the provisions of Article 26 of the Convention implementing the Schengen Agreement of 14 June 1985. (Disponível em http://eurlex.europa.eu/legal-content/EN/TXT/PDF/?uri=CELEX:32001L0051\&from=FR). (Último acesso em 22/01/2016). 
transportadoras assumir responsabilidades pela estada dos estrangeiros cuja entrada for recusada, até retorno ao país de origem ${ }^{176}$. Em outras palavras, as companhias áreas têm responsabilidade de verificar se a documentação e os vistos dos passageiros são adequados para a entrada no país de destino, sob pena de significativas perdas financeiras, já que, de acordo com o artigo $4^{\circ}$, da mesma Diretiva, as sanções a elas aplicadas devem ser "dissuasivas, eficazes e proporcionais” $^{177}$.

Enquanto o Parlamento Europeu argumenta ${ }^{178}$ que as sanções não trazem riscos aos solicitantes de refúgio, pois as empresas negarão provavelmente os bilhetes somente quando os requisitos não são atendidos, o Conselho Europeu para os Refugiados e Exilados reconhece que as empresas de transporte vão continuar cumprindo esta regra, desde que seja economicamente mais benéfica, o que significa, na prática, negar viagem a um potencial solicitante de refúgio se isso puder resultar em multa e despesas com repatriação ${ }^{179}$.

No lugar da tradicional retórica de combate aos “coiotes” e em vez das medidas paliativas para evitar as mortes dos migrantes e refugiados, seria mais justo assumir a inconveniência da Diretiva ou, pelo menos, decidir sua suspensão para nacionais de países cuja população sofre com os conflitos, como é o caso da

\footnotetext{
${ }^{176}$ Art. 3. Member States shall take the necessary measures to oblige carriers which are unable to effect the return of a third-country national whose entry is refused to find means of onward transportation immediately and to bear the cost thereof, or, if immediate onward transportation is not possible, to assume responsibility for the costs of the stay and return of the third country national in question. (Disponível em http://eur-lex.europa.eu/legalcontent/EN/TXT/PDF/?uri=CELEX:32001L0051\&from=FR). (Último acesso em 22/01/2016).

${ }^{177}$ Article 41 . Member States shall take the necessary measures to ensure that the penalties applicable to carriers under the provisions of Article 26(2) and (3) of the Schengen Convention are dissuasive, effective and proportionate and that: (a) either the maximum amount of the applicable financial penalties is not less than EUR 5000 or equivalent national currency at the rate of exchange published in the Official Journal on 10 August 2001, for each person carried, or (b) the minimum amount of these penalties is not less than EUR 3000 or equivalent national currency at the rate of exchange published in the Official Journal on 10 August 2001, for each person carried, or (c) the maximum amount of the penalty imposed as a lump sum for each infringement is not less that EUR 500000 or equivalent national currency at the rate of exchange published in the Official Journal on 100 August 2001, irrespective of the number of persons carried. (Disponível em http://eur-lex.europa.eu/legal-content/EN/TXT/PDF/?uri=CELEX:32001L0051\&from=FR). (Último acesso em 22/01/2016).

178 "Directorate-General for external policies of the Union. Directorate B. Policy Department Study. Analysis of the external dimension of the EU's asylum and immigration policies' summary and recommendations for the European Parliament”. (Disponível emhttp://www.europarl.europa.eu/meetdocs/2004_2009/documents/dt/619/619330/619330en.pdf). (Último acesso em 22/01/2016).

179 European Council on Refugees and Exiles. "Carrier Sanctions". (Disponível em http://www.ecre.org/topics/areas-of-work/access-to-europe/7-carrier-sanctions.html). （Último acesso em 22/01/2016).
} 
Síria, Afeganistão, Eritreia e Iraque, dentre outros. Opositores sustentam que isso facilitaria demasiadamente a viagem, encorajando a chegada de mais refugiados na Europa. No entanto, as pessoas, apesar de todos os riscos e gastos, continuam fazendo tudo o que for possível para fugir da guerra e da morte.

E lançar-se ao mar em pequenos botes é apenas um dos riscos. De acordo com relatório elaborado conjuntamente pelo ACNUR, o Fundo de Populações das Nações Unidas (UNFPA) e Comissão para Mulheres Refugiadas (WCR), mulheres e crianças que chegam à Europa na condição de refugiadas estão sendo submetidas a violência sexual como forma de "pagar" pela viagem ou pelos documentos que permitem a viagem.

Muitas delas foram expostas a diferentes formas de violência sexual e de gênero em seu país de origem e no primeiro país de chegada, assim como ao longo da viagem até a Europa. Algumas delas relatam terem sido forçadas a manter relações sexuais como forma de pagamento pela documentação para viajar ou pela própria viagem. Nos primeiros quinze dias de 2016, 55\% das pessoas que chegaram à Europa eram mulheres e crianças. No ano anterior, eram apenas $27 \%^{180}$.

\section{5}

\section{A crise da gestão: acordos para controle de fronteira}

Na Comunidade Europeia, a crise dos refugiados é uma questão de polícia e, portanto, uma gestão de polícia. Entre 2007 e 2013, a União Europeia destinou quatro bilhões de euros para lidar com a questão dos refugiados, mas, de acordo com a Anistia Internacional ${ }^{181}$, apenas $17 \%$ do montante foi utilizado para aprimoramento dos procedimentos de recepção a solicitantes de refúgio e integração de refugiados. A maior parte do orçamento foi usada em militarização

180 "Mulheres e crianças são estupradas como forma de 'pagar' entrada na Europa”. Revista Forum. 28/01/2016. (Disponível em http://www.revistaforum.com.br/2016/01/28/mulheres-ecriancas-sao-estupradas-como-forma-de-pagar-entrada-na-europa/). (Último acesso em 04/02/2016).

181 "The human cost of fortress Europe. Human rights violations against migrants and refugees at Europe's borders”. Anistia Internacional. 2014. (Disponível em https://www.amnesty.ch/de/themen/asyl-und-migration/festung-europa/dok/2015/Die-KampagneSOS-Europa/bericht-the-human-cost-of-fortress-Europe). (Último acesso em 08/02/2016). 
das fronteiras, detenção, vigilância e deportação ${ }^{182}$. E ainda há todo o dinheiro utilizado para a "terceirização" das fronteiras, especialmente através de acordos com a Turquia.

Somente em 2012, a União Europeia destinou às autoridades turcas cerca de 20 milhões de euros para compra de equipamentos, com a condição de ter o “fortalecimento da capacidade de vigilância das fronteiras”. Justamente logo após a explosão de fluxo de sírios ao país, com a chegada de 280 mil pessoas. No total, a ajuda da Comissão Europeia para a Turquia enfrentar a crise dos refugiados sírios somava 42,8 milhões de euros. O governo turco reclamava uma despesa de 1,84 bilhões com a crise ${ }^{183}$.

A União Europeia estabeleceu acordos oficiais com países vizinhos, pelos quais dão suporte a sistemas de controle migratório, no esforço de bloquear os refugiados e migrantes antes mesmo de chegarem às fronteiras da Europa. Foram feitos acordos de cooperação com países como Líbia, Marrocos, Turquia e Ucrânia, dentre outros, na tentativa de transforma-los em países-muros em torno da União Europeia.

Os acordos assumem diversas formas, tais como diálogos políticos bilaterais ou regionais, acordos de facilitação de vistos e readmissão, e financiamento ou apoio operacional a partir de agências da UE como a Frontex. Envolve, em alguns casos, financiamento de equipamento de vigilância das fronteiras, formação de guardas de fronteira e guarda costeira, e a criação de sistemas de compartilhamento de informações, de forma a interromper a jornadas dos migrantes e refugiados nos países "terceiros", antes que cheguem à UE. Alguns acordos preveem financiamento, construção ou aprimoramento das instalações de detenção, como, por exemplo, nos casos dos acordos com Turquia e Ucrânia.

Embora a União Europeia considere oficialmente que a garantia dos direitos humanos dos refugiados e migrantes sejam componentes importantes de sua política de migração, incluindo a proteção aos solicitantes de refúgio, muitos

\footnotetext{
182 "The next refugee crisis". Jacobin. Christian Parenti. (Disponível em https://www.jacobinmag.com/2016/01/refugees-europe-merkel-germany-migrants-franceemergency/). (Último acesso em 08/02/2016).

183 "The human cost of fortress Europe. Human rights violations against migrants and refugees at Europe's borders. Anistia Internacional, 2014. (Disponível em https://www.amnesty.ch/de/themen/asyl-und-migration/festung-europa/dok/2015/Die-KampagneSOS-Europa/bericht-the-human-cost-of-fortress-Europe). (Último acesso em 09/02/2016).
} 
destes acordos de cooperação significam, na realidade, medidas concretas de prevenção e repulsa de migrantes e eventuais solicitantes de refúgio.

O acordo elaborado pela Comissão Europeia para permitir a entrada de cidadãos turcos com isenção de vistos obriga a Turquia adotar medidas "plenas e eficazes” de readmissão. Exige que Turquia "celebre acordos de readmissão com os países que representam fontes de importantes fluxos de imigração clandestina dirigida para a Turquia ou os Estados-Membros da UE." O regime de isenção de vistos também exige que Turquia demonstre esforços concretos na implementação de "controles fronteiriços adequados e vigilância das fronteiras ao longo de todas as fronteiras do país, especialmente ao longo das fronteiras com estados membros da UE, de modo a reduzir significativamente o número de pessoas que atravessam ilegalmente as fronteiras turcas seja para entrar ou para sair da Turquia”.

Não existe nenhum mecanismo para avaliar os impactos dos acordos de cooperação ou sobre os riscos para as pessoas que queiram solicitar refúgio, por exemplo. Pesquisas realizadas pela Anistia Internacional mostraram um dos efeitos destes acordos foi colocar refugiados, solicitantes de refúgio e migrantes sob risco de detenção prolongada e arbitrária, devolução infundada (refoulement ${ }^{184}$ ) e maus tratos nos países "terceirizados". Além disso, as negociações e os acordos de cooperação não são transparentes e alguns estados membros da UE nem sequer tornaram públicos os acordos que já entraram em vigência.

A União Europeia também tem acordos que preveem financiamento de um grande número de atividades relacionadas a políticas de migração nos "terceiros” países. O valor exato é ignorado, mas um dos principais acordos, chamado Programa Temático para Migração e Asilo, teve orçamento de 384 milhões de euros para ações relacionadas com migração em países fora da comunidade europeia, durantes os anos de 2007 a 2013.

\footnotetext{
${ }^{184}$ Devolução (Refoulement) é o regresso forçado de alguém a um país onde o solicitante de refúgio estaria em risco de graves violações dos direitos humanos. O direito internacional proíbe a transferência de qualquer pessoa para um lugar onde a sua vida ou liberdade esteja em risco - isto é conhecido como o princípio de não-devolução (non-refoulement). Tornou-se tão amplamente aceito que ele atingiu o status de direito internacional consuetudinário, o que significa que é vinculativa para todos os Estados, incluindo os que não ratificaram os instrumentos internacionais relevantes. Alguns atores não-estatais também estão vinculados ao princípio de não repulsão, como, por exemplo, a Frontex.
} 
Em maio de 2014, a UE assinou acordos de “readmissão” com 17 países: Albânia, Arménia, Azerbaijão, Bósnia e Herzegovina, Cabo Verde, Geórgia, Hong Kong, Macau, Macedónia, Moldávia, Montenegro, Paquistão, Rússia, Sérvia, Sri Lanka, Turquia e Ucrânia. As negociações incluíram ainda Argélia, Bielorrússia, China e Marrocos. O acordo de readmissão estabelece a expulsão de cidadãos não pertencentes à comunidade europeia, independentemente da autorização do país de origem ou trânsito.

Ainda que o acordo seja concernente apenas a migrantes irregulares - o que já deveria ser alarmante --, há sérias preocupações em relação aos solicitantes de refúgio que eventualmente possam ser devolvidos sem acesso aos procedimentos de refúgio. Esta preocupação é relevante, por exemplo, quanto aos casos de Bulgária e Grécia, dentre outros Estados com sistemas de refúgio considerados “frágeis” ou “deficientes”. Tal preocupação é ainda maior em relação às áreas de fronteira, onde procedimentos sumários podem ser aplicados sem dar chance de recursos às pessoas que eventualmente precisam de proteção.

Em 2011, a Comissão Europeia havia apresentado uma avaliação dos acordos de readmissão e fez recomendações concretas para excluir os nacionais de países terceiros os efeitos dos acordos. E recomendou incluir cláusulas de suspensão em caso de riscos persistentes e graves violações dos direitos humanos de pessoas sujeitas à readmissão. A Comissão recomendou também a participação de organizações internacionais e não-governamentais nos "Comitês Mistos de Readmissão", para fiscalização dos acordos de readmissão. No entanto, nenhuma dessas recomendações foi considerada quando, por exemplo, a UE formalizou acordo de readmissão com a Turquia, em Dezembro 2013.

Os estados membros também assinaram acordos bilaterais com países terceiros: a Grécia formalizou acordo de readmissão com a Turquia, a Espanha com Marrocos e a França com o Benin, Burkina Faso, Camarões, Cabo Verde, Congo, Gabão, Senegal, Tunísia e Maurício. Pelo acordo assinado em dezembro de 2013, a Turquia se compromete a fazer a "readmissão" de migrantes irregulares que passem por seu território tentando ingressar na UE. Estima-se que Bulgária e Grécia sejam os principais estados membros a fazer uso dos acordos de readmissão, como forma de bloquear os refugiados e migrantes que tentam entrar na UE pela Turquia. 
Mesmo com aprimoramentos legislativos, a Turquia mantém deficiências significativas em seu sistema de refúgio (asilo) e problemas graves em suas instalações de detenção. As pessoas devolvidas (ou “readmitidas”) à Turquia, nos termos do acordo, podem ser colocadas automaticamente em detenção, sem acesso aos procedimentos de refúgio, sob risco de maus tratos, conforme inúmeros relatos. Em 16 de Abril de 2014, o Gabinete do Primeiro-Ministro na Turquia emitiu uma ordem para a criação de novos centros de remoção e a expansão dos já existentes, para reter os migrantes irregulares enquanto aguardam a deportação. A medida foi explicitamente anunciada como parte do acordo de readmissão assinado com a UE.

A União Europeia pretende definir Turquia como país seguro ${ }^{185}$ - o que, na prática, significaria restrição à mobilidade dos solicitantes que passam pelo território turco em busca de proteção na Europa -, contudo, os relatos sobre perseguições a cidadãos do próprio país, sobretudo os curdos, mas também jornalistas e opositores fazem crer no contrario. Os países da UE aprovaram 23\% dos pedidos de refúgio apresentados por cidadãos perseguidos na Turquia, e o Tribunal Europeu de Direitos Humanos elencou 94 violações de direitos humanos no país ${ }^{186}$.

Um dos primeiros países a adotar a Convenção de Genebra de 1951, a Turquia nunca aderiu à remoção da limitação geográfica como fizeram os demais países signatários do Protocolo de 1967. A Turquia, deste modo, reconhece como refugiados apenas os solicitantes provenientes de países europeus, nos termos da redação original da Convenção de $1951^{187}$.

Aos nacionais de outros países, especialmente os sírios, afegãos, iraquianos e iranianos, a Turquia oferece uma forma de proteção temporária. São três

185 Como demonstra o documento "Regulation of the European Parliament and the Council establishing an EU common list of safe countries of origin for the purposes of Directive 2013/32/EU of the European Parliament and of the Council on common procedures for granting and withdrawing international protection, and amending Directive 2013/32/EU”, de 09/09/2015.

(Disponível em http://eur-lex.europa.eu/resource.html?uri=cellar:a5874209-56cc-11e5-afbf01aa75ed71a1.0009.02/DOC_1\&format=PDF). (Último acesso em 14/02/2016).

186 “No, EU, Turkey is not safe for everyone”. Open Democracy. EmmaSinclair.23/10/2015. (Disponível em https://www.opendemocracy.net/emma-sinclair-webb/no-eu-turkey-is-not-safefor-everyone). (Último aceso em 14/02/2016).

${ }^{187}$ As declarações de reserva feitas pela Turquia ao Protocolo encontram-se no texto do próprio Protocolo, que está disponível no site do ACNUR (http://www.unhcr.org/4dac37d79.html) e no relatório do ACNUR sobre a Turquia (Disponível em http://www.refworld.org/pdfid/5541e6694.pdf). (Último acesso em 14/02/2016) 
categorias de pessoas deslocadas no país: a primeira, dos refugiados, reservada aos que fogem da Europa, nos termos da Convenção de 1951; a segunda, dos refugiados que esperam reassentamento em terceiro país e, por fim, as pessoas que estão sob proteção “subsidiária”.

É nesta última categoria que os sírios, por exemplo, estão sendo classificados, a partir de uma decisão da Direção Geral da Gestão de Migração da Turquia, com apoio do ACNUR. Este status de proteção, no entanto, não permite aos refugiados trabalhar, nem tampouco a se candidatar para outras formas de proteção. São ainda obrigados a viver em cidades satélites, fora dos principais centros, como é o caso de Istambul ${ }^{188}$.

188 “Turkey is doing the dirty work of Europe's immigration control. Open Democracy. Lucy Williams. 22/01/2016. (Disponível em https://www.opendemocracy.net/can-europe-make-it/lucywilliams/turkey-is-doing-dirty-work-of-europe-s-immigration-control). (Último acesso em 14/02/2016). 
A crise da soberania. Europa como paradigma

\author{
"And what have I got? \\ Why am I alive anyway? \\ Yeah, what have I got \\ Nobody can take away? \\ I got my arms, I got my hands
}

I've got life, I've got my freedom. I've got the life”

Nina Simone ${ }^{189}$

A desigualdade na gestão da crise dos refugiados é forçada pela retórica da crise. É justamente na parte mais rica do mundo que este discurso ganha força e serve para justificar e legitimar a violência bruta contra os refugiados. Desde que os sujeitos decidiram fugir em direção ao continente europeu, a crise ganhou outras proporções e colocou em evidência a violência como fundamento do paradigma europeu no que diz respeito à democracia.

Em meio à maior crise humanitária das últimas décadas, o PrimeiroMinistro da França, Manuel Valls - membro do Partido Socialista - declarou à imprensa que o “conceito” de Europa está em "grave risco” por causa dos refugiados, acrescentando que "nossas sociedades estão totalmente desestabilizadas” ${ }^{190}$. "Se a Europa não é capaz de proteger suas fronteiras, a ideia de Europa será questionada”, disse ele em entrevista a um jornal britânico, durante o Fórum Econômico de Davos, ocorrido em janeiro de 2016. Disse ainda que a Europa não pode dar conta de todos os refugiados fugindo da Síria e do Iraque e, portanto, é preciso criar proteção para as fronteiras.

As declarações do francês fazem coro com as preocupações do Primeiro Ministro Holandês (líder do Partido pela Liberdade e Democracia), Mark Rute, para quem a crise deve ser resolvida nos "próximos seis a oito meses”. Antes que o acordo de Schengen "seja morto”, disse o Ministro holandês, “a União Europeia deve tentar fazer valer as normas de Dublin”, pelas quais os refugiados devem

\footnotetext{
189 Trecho da canção “Ain’t got no (I got life)”.

190 "French PM Manuel Valls says refugee crisis is 'destabilizing' Europe”. The Guardian. Larry Elliott e Jill Treanor. (Disponível em http://www.theguardian.com/world/2016/jan/22/french-pmmanuel-valls-says-refugee-crisis-is-destabilising-europe). (Último acesso em 22/01/2016).
} 
procurar proteção no primeiro país de acolhida. A Áustria, por sua vez, anunciou poucos dias antes que planeja limitar o número de pessoas autorizadas a solicitar asilo, restringindo a 1,5\% de sua população ao longo dos próximos quatro anos. Neste ano, o número será limitado a 37.500.

Meses antes, o governo belga havia proposto à Comissão Europeia a criação de um “corpo europeu de guardas de fronteira” que pudesse ser acionado imediatamente em casos de emergência, em qualquer fronteira da União Europeia $^{191}$. O ponto mais polêmico é que o corpo de guardar poderia ser enviado para qualquer fronteira, independentemente do consentimento do Estado que enfrenta a "crise", ou até mesmo a despeito de sua opinião. A intervenção, neste caso, seria obrigatória para o Estado-membro.

A preocupação de Bruxelas está dirigida principalmente à entrada de pessoas pela Grécia e Itália. A ideia é compor uma força com pelo menos 1500 policiais, com complementação da equipe da Frontex, a agência europeia de fronteiras. E transformar a Frontex na Agência Europeia de Guardas de Fronteira, a qual caberá avaliar quando uma intervenção deve se realizar. Nenhum outro país apoiou explicitamente a ideia, especialmente em razão de seu caráter impositivo e obrigatório.

$\mathrm{Na}$ Alemanha, a política de portas abertas aos refugiados encontrou seus limites. Milhares de solicitantes de refugio aguardavam solução para seus pedidos em alojamentos improvisados dentro do aeroporto Tempelhof, em Berlim, enfrentando temperaturas extremamente frias. Em novembro de 2015, havia pelo menos 40 mil solicitantes de refúgio apenas na capital, lotando abrigos emergenciais erguidos em escolas e quadras de esportes.

Em outubro de 2015, o histórico aeroporto de Tempelhof -- uma gigantesca estrutura de 300 mil metros quadrados, construída nos anos 1930, que ficou famoso por ter sido utilizado pelos Aliados durante a Guerra Fria -- tornou-se a solução para o fluxo de pessoas que chegam para pedir refúgio, durante os rigorosos meses de inverno. No total, eram duas mil pessoas no aeroporto, dentre

191 “Bruselas pide una policía europea de fronteras desplegable en tres días”. El Pais. Lucia Abellan e Claudi Pérez.11/12/2015.(Disponível em http://internacional.elpais.com/internacional/2015/12/11/actualidad/1449832662_879236.html). (Último acesso em 21/01/2016). 
as quais 500 crianças. De acordo com avaliação do escritório do $\operatorname{ACNUR}^{192}$, a instalação não atende as necessidades dos solicitantes. Não há chuveiros, nem torneiras nos banheiros disponibilizados e os sanitários não são adequados.

$\mathrm{Na}$ tentativa de sensibilizar os líderes europeus sobre a necessidade de compartilhar o ônus com a crise dos refugiados, e também de angariar a simpatia do eleitorado comovido com as mortes no mar, o governo alemão anunciou sua política de portas abertas, declarando, dentre outras coisas, o investimento de seis bilhões de euros, em 2016, para a recepção de refugiados ${ }^{193}$. Quando o anúncio foi feito, a estimativa era de que 800 mil pessoas haviam entrado no país. Em dois meses, o número subira para 964.574 pessoas $^{194}$.

O valor corresponde a quase $60 \%$ das despesas adicionais previstas no orçamento e, portanto, não é irrelevante. Nem economicamente, nem politicamente. Parte do dinheiro será destinada, segundo declarações, à construção de 150 mil alojamentos para o inverno e 300 mil unidades habitacionais a serem construídas pelos municípios, através de financiamento de bancos públicos. O governo também anuncia a criação de quatro mil postos de trabalho na agência federal para migração e refúgio.

Em parte, a generosidade de Merkel atende a uma expectativa de parte da população, especialmente depois da onda de comoção com o caso do menino Aylan Kurdi. A reação da opinião pública contra os ataques promovidos contra os centros de acolhimento a refugiados provavelmente deixaram evidente o sentimento coletivo de solidariedade. E a crise dos refugiados abre para Merkel a oportunidade de aparecer como forte líder na Europa - inclusive para colocar como pauta a cota de refugiados para os países europeus -- na medida em que ela toma a palavra contra a maioria dos líderes europeus, e também para restaurar o prestígio do país, mudando a imagem negativa que restou depois da indiferença com a crise grega.

192 “Asylum-seekers await application results at historic Berlin airport”. UHNCR. 17/11/2015.(Disponível em http://www.unhcr.org/564ae4796.html). (Último acesso em 20/01/2016).

193 “Pourquoi Angela Merkel est-elle si généreuse envers les réfugiés ?” EurActiv. 08/09/2015. (Disponível em http://www.euractiv.fr/sections/leurope-dans-le-monde/pourquoi-angela-merkel-est-elle-sigenereuse-envers-les-refugies). (Último acesso em 20/01/2016).

194 “Merkel promete diminuir a entrada de refugiados na Alemanha” Agência Brasil.14/12/2015. (Disponível em http://ultimosegundo.ig.com.br/mundo/2015-12-14/merkel-promete-diminuir-a-entrada-derefugiados-na-alemanha.html). (Último acesso em 20/01/2016). 
Além disso, há quem aponte para a questão demográfica, intimamente relacionada com a questão econômica. O país precisa do ingresso maciço de jovens para trabalhar e consumir, especialmente diante do fato de que $46 \%$ dos empregadores alemães demonstram dificuldade para recrutamento ${ }^{195}$. Angela Merkel, contudo, faz um jogo ambíguo, agradando também as reivindicações mais conservadoras. Dentre outras medidas, a Alemanha considera Macedônia, Albânia e Kosovo como "país seguro” para refugiados, facilitando, desta maneira, a recusa aos pedidos feitos por pessoas provenientes destes países e garantindo sua expulsão de forma mais rápida.

É um modo de separar dos refugiados que fogem da guerra no Oriente Médio os "migrantes econômicos” dos Balcãs. A expulsão, segundo as expectativas, deve acontecer em três semanas após a rejeição do pedido de refúgio $^{196}$. Diversas entidades de direitos humanos expressaram preocupações com a violação a normas de direito de refúgio. A queda da popularidade de Merkel, junto com as críticas generalizadas feitas por seus aliados, causou outros retrocessos em relação ao tema dos refugiados e solicitantes de refúgio.

Outras medidas adotadas obrigam os solicitantes de refúgio a se registrarem imediatamente ao entrarem no país, inibindo a circulação para outros países da Europa. Foi cogitada, entre os parceiros da coalizão do governo Merkel, a criação de "zonas de trânsito", que, na prática, correspondem a centros de detenção. A ideia foi criticada com ironia pelo programa de tevê satírico "Extra 3”: “Os alemães vão colocar pessoas em um campo. Uma grande ideia que há muito tempo não se tinha”. Embora não tenham sido aprovadas, o governo conseguiu a aprovação das zonas de registro ${ }^{197}$.

O reagrupamento familiar entre os refugiados e suas famílias também foram alvo das mudanças. Agora os refugiados terão que esperar até dois anos para obter a reunião com seus familiares, como forma de "controlar o fluxo atual de refugiados”. A iniciativa, que, segundo entidades de direitos humanos, contraria

\footnotetext{
195 “Pourquoi Angela Merkel est-elle si généreuse envers les réfugiés ?’” EurActiv. 08/09/2015. (Disponível em http://www.euractiv.fr/sections/leurope-dans-le-monde/pourquoi-angela-merkel-est-elle-sigenereuse-envers-les-refugies). (Último acesso em 20/01/2016).

196 “Alemania creará centros para expulsar más rápido a los solicitantes de asilo rechazados”. El Diario. Carmela Negrete. 06/11/2015. (Disponível em http://www.eldiario.es/desalambre/AlemaniaMerkel-refugiados-coalicion-centros-deportaciones_0_449355196.html). (Último acesso em 21/01/2016).

${ }^{197}$ Idem
} 
convenções internacionais, foi criticada pelo escritório do ACNUR, para o qual, a reunião familiar é uma forma de evitar que os refugiados arrisquem suas vidas em viagens perigosas ${ }^{198}$.

Na fronteira com a Áustria, a situação é descrita como caótica. Milhares de pessoas, incluindo muitas crianças, tentavam, no final do ano de 2015, cruzar a fronteira pelas cidades de Passau, Freilassing e Lindau, enfrentando longas filas, em céu aberto, sob temperaturas extremamente frias. É uma tentativa de criar a imagem de que a Alemanha está no limite de sua capacidade.

A Noruega fechou sua fronteira com a Rússia e decidiu deportar todos os migrantes e refugiados que entraram no país por ela. O governo norueguês afirma que as 5.500 pessoas que cruzaram a fronteira em 2015 - a maioria proveniente de países do Oriente Médio -- serão devolvidas para a Rússia. Em janeiro de 2016, aproximadamente 70 pessoas que aguardavam a deportação anunciaram greve de fome. Apesar disso, elas foram devolvidas à Rússia ${ }^{199}$.

O governo da Suécia anunciou, por sua vez, no final de janeiro de 2016, que se prepara para rejeitar até 80 mil pessoas que pediram refúgio (asilo) no país. Eles serão forçados a deixar o país contra sua vontade. O Ministério do Interior solicitou às forças policiais e às autoridades de migração para que se preparem para as deportações. A Suécia recebeu mais de 160 mil pedidos de refúgio (asilo) em 2015 - o maior número proporcionalmente ao tamanho de sua população dentro da União Europeia.

Com as medidas, o país pretende enviar a mensagem de que não é mais tão receptiva aos refugiados. Em 2015, a Suécia rejeitou 20 mil solicitantes de refúgio, o que significa $45 \%$ dos pedidos. Cerca de três mil foram deportados. Em 2016, as autoridades acreditam que o índice de aprovação será maior, porque a maioria dos pedidos foi feito por cidadãos do Afeganistão e Síria. O governo da Suécia está em negociações com outros países da União Europeia, inclusive Alemanha, para discutir como organizar a eficiência das medidas de deportação.

Outros países escandinavos também seguem a mesma política: ainda em janeiro de 2016, a Noruega começou a deportação de solicitantes de refúgio de

\footnotetext{
${ }^{198}$ Idem

199 "Flow of refugees via Russia to Norway dries up in recent weeks". Sputnik News. 20/01/2016. (Disponível emhttp://sputniknews.com/europe/20160120/1033440185/migration-russianorway.html ). (Último acesso em 09/02/2016).
} 
volta para a Rússia e a Dinamarca aprovou o confisco de dinheiro e valores que os solicitantes de refúgio trazem consigo. Antes disso, as fronteiras entre Suécia e Dinamarca já tinham sido bloqueadas, fazendo cair drasticamente a entrada de solicitantes de refúgio. O país espera que o número de solicitações fique em 45 mil em $2016^{200}$.

Na Dinamarca, a despeito dos protestos de organizações internacionais de direitos humanos, o Parlamento dinamarquês aprovou, em 26/01/2016, por maioria de votos (81 dos 109 presentes), medidas para conter a entrada de refugiados e migrantes no país. A mais polêmica é a que permite o confisco de bens dos solicitantes de refúgio e refugiados, sob o pretexto de que eles financiarão sua acolhida.

Há outras medidas igualmente criticadas, como as que determinam cortes nos direitos sociais dos solicitantes de refugio e a dilatação do prazo para reunião familiar. As pessoas que chegarem ao país terão suas bagagens revistadas e terão apreendidos objetos e quantias em dinheiro cujo valor exceda 10 mil coroas dinamarquesas, o que corresponde a cerca de 1.600 reais. Apenas bens de valor sentimental não podem ser apreendidos.

O ACNUR considera que as medidas alimentam sentimentos de medo e xenofobia e são respostas preocupantes frente a necessidades humanitárias. E também considera extremamente grave o confisco de bens. Em 2015, a Dinamarca recebeu 21 mil refugiados, número recorde em um país no qual cerca de 70\% da população se preocupa com o tema da imigração, conforme pesquisas de opinião pública.

A Anistia Internacional pediu ao parlamento da Dinamarca a rejeição das propostas de mudanças na lei de refúgio, sob a justificativa de que elas terão “impacto devastador sobre as pessoas vulneráveis” e porque violam leis internacionais de direitos humanos. Dentre as mudanças, a emenda inclui que os refugiados deverão esperar até três anos para obter a reunião familiar, isto é, a possibilidade de conseguir trazer seus familiares que ficaram no país de origem. Para o representante da Anistia Internacional (Diretor do escritório para Europa e

\footnotetext{
200 "Sweden sends sharp signal with plan to expel up to 80,000 asylum seekers". The Guardian. David Crouch. 28/01/2016. (Disponível em http://www.theguardian.com/world/2016/jan/28/sweden-to-expel-up-to-80000-rejected-asylumseekers). (Último acesso em 28/01/2016).
} 
Ásia Central), Gauri van Gulik, a medida é “cruel por forçar os refugiados a fazer uma escolha impossível: trazer seus filhos e outros familiares e enfrentar os perigos da jornada ou deixa-los para trás e enfrentar uma prolongada separação enquanto os familiares continuam sofrendo os horrores da guerra ${ }^{201}$.

Assim como a Dinamarca, a Suíça pretende adotar as medidas de confisco de bens com valores superiores a mil francos suíços (quatro mil reais). Além disso, os refugiados devem entregar $10 \%$ de seu salário pelo prazo de dez anos, até completar o valor de 15 mil francos suíços. Os estados de Baviera e BadenWürttemberg, no Sul da Alemanha, também colocaram o confisco em prática, apoiando-se em uma lei nacional segundo a qual solicitantes de refúgio devem consumir seus próprios bens antes que o Estado possa prover seu sustento ${ }^{202}$.

O Partido Trabalhista holandês apresentou um plano para devolver imediatamente à Turquia os refugiados e migrantes que chegam à Grécia, como forma de conter o fluxo de pessoas chegando à Europa. A Holanda, que atualmente tem a presidência da União Europeia, busca apoio entre os parceiros europeus. De acordo com o plano, os refugiados que chegarem à Grécia serão imediatamente devolvidos à Turquia.

Em troca, a União Europeia concorda em receber, por ano, 250 mil refugiados residentes na Turquia. A proposta pretende desencorajar a perigosa rota pelo Mar Egeu, segundo seus defensores. O plano, porém, depende também de que a Turquia tenha o status de "país seguro para refugiados”, o que implica adoção e aprimoramento de sua legislação.

A proposta tem sido severamente criticada por ativistas, políticos e intelectuais. Segundo alguns críticos, a Europa pretende apenas transferir o problema para um país inseguro, violando a Convenção de Genebra, que determina aos Estados a obrigação de processar o pedido de refúgio no país onde ele é requerido. O plano é similar à política adotada pela Austrália em 2013,

\footnotetext{
${ }^{201}$ Denmark urged to reject 'cruel' refugee laws'. Aljazeera. 21/01/2016. (Disponível em http://www.aljazeera.com/news/2016/01/denmark-urged-reject-cruel-refugee-laws160121045329929.html). (Último acesso em 21/01/2016).

202 "Dinamarca aprova proposta polêmica que permite confiscar bens de imigrantes". O Globo. 28/01/2016. (Disponível em http://oglobo.globo.com/mundo/dinamarca-aprova-propostapolemica-que-permite-confiscar-bens-de-imigrantes-18542877). (Último acesso em 09/02/2016).
} 
quando os refugiados eram rechaçados e enviados a centros de detenção em Nova Guiné e outras ilhas ${ }^{203}$.

\section{1}

\section{A Fortaleza Europeia e a polícia como governabilidade}

A política restritiva e repressiva tomou a Europa desde que a crise dos refugiados anunciava seu ápice. Em Londres, as autoridades cogitaram obrigar os médicos e os bancos a denunciar os migrantes indocumentados. O objetivo da nova lei, de acordo com Theresa May, uma conservadora que assumiu o Ministério do Interior, seria “criar um entorno realmente hostil para os imigrantes ilegais" 204 .

Para tanto, as autoridades pretendem contar com um grande contingente de delatores, de forma a dificultar a vida dos refugiados e migrantes, excluindo-os da possibilidade de acesso aos serviços médicos, serviços bancários ou a um matrimonio que possa, enfim, regularizar sua situação no país. O efeito destas medidas restritivas, segundo creem as organizações humanitárias, é a precarização cada vez maior da vida destas pessoas, que terão que pagar ainda mais por habitações insalubres, sofrerão com agravamento das enfermidades e aceitarão qualquer tipo de trabalho para conseguir ainda menos dinheiro. Ninguém parece realmente crer que eles irão embora.

A proposta de lei também pretende facilitar a deportação, diminuindo a defesa daqueles considerados migrantes. Se antes havia 17 hipóteses para apelação contra a ordem de deportação, a nova lei prevê somente quatro, todas elas dentro da nova perspectiva de “deportar primeiro, apelar depois”. Se a pessoa não corre risco de dano irreversível, ela deve ser devolvida. Cartazes espalhados pelos subúrbios de Londres incluem frases como "vá para casa ou arrisque-se a ser detido”. É nos subúrbios da cidade que são feitas operações de identificação de

\footnotetext{
203 "Dutch plan seeks to ferry refugees back to Turkey”. Al Jazeera. 30/01/2016. (Disponível em http://www.aljazeera.com/news/2016/01/netherlands-plan-ferry-refugees-turkey160128170612335.html. (Último acesso em 04/02/2016).

204 "Londres obligará a médicos y banqueros a delatar a los imigrantes 'sin papeles'”. Legalcity, 28/10/2013.

(Disponível em http://internacional.elpais.com/internacional/2013/10/27/actualidad/1382897544_669353.html) (Último acesso em 29/04/2016).
} 
migrantes indocumentados, incluindo divulgação de mensagens pelo twitter com fotografias de suspeitos ${ }^{205}$.

Indivíduos de "pele escura” são os principais alvos dos agentes de migração, que abordam os "suspeitos” nas estações de metro e trem. Apesar das reações críticas, David Cameron, Primeiro Ministro do Reino Unido, anunciou que as alterações nas leis de migração - com mais restrições aos benefícios sociais e serviços de saúde - são prioridade de seu governo.

A detenção indefinida e arbitrária de solicitantes de refúgio continua sendo uma das principais violações a direitos das pessoas refugiadas. O "Home Office", escritório para migração e refúgio do Reino Unido ofereceu desculpas oficiais e pagou uma indenização (não divulgada) a uma solicitante de refúgio grávida que foi ilegalmente detida no centro de detenção para migrantes Yarl’s Wood. Ela foi detida sem nenhum aviso, em Fevereiro de 2014. Ficou cerca de dez horas em uma delegacia antes de ser enviada ao centro de detenção, em uma jornada que durou oito horas.

O governo admite que a mulher, uma solicitante de refúgio congolesa, estava grávida de cinco meses quando foi detida em 2014, contrariando as normas locais. De acordo com as diretrizes atuais, as mulheres grávidas são consideradas “vulneráveis” e, portanto, não podem ser colocadas em detenção, a não ser por motivos excepcionais. De acordo com o relatório das Inspeções de Prisões, pelo menos 99 mulheres grávidas foram detidas em Yarl's Wood em 2014 e nove foram removidas do Reino Unido. No pedido de desculpas, o Ministério do Interior admitiu que violou a própria política ${ }^{206}$.

No entanto, em setembro de 2013, ao ser indagado sobre a detenção de mulheres grávidas nos centros de migração, o Ministro da Imigração respondeu literalmente que "muitas mulheres se declarariam grávidas como estratégia para atrasar sua partida do Reino Unido". E acrescentou: "Eu tenho visto as pessoas usando muitos obstáculos, quando elas não têm o direito de estar aqui e eu não

205 “Campanha contra imigração sem documentos gera acusações de racismo no Reino Unido”, O Público, 02/08/2013.(Disponível em https://www.publico.pt/mundo/noticia/campanha-contraimigracao-sem-documentos-gera-acusacoes-de-racismo-no-reino-unido-1602040) (último acesso em 21/05/2016).

206 "Home Office to compensate pregnant asylum seeker for unlawful detention". The Guardian. Diane Taylor. 06/10/2015. (Disponível em http://www.theguardian.com/uknews/2015/oct/06/home-office-to-compensate-pregnant-asylum-seeker-for-unlawful-detention). (Último acesso em 25/01/2016). 
quero que este seja um deles. Estamos comprometidos com o tratamento correto a mulheres grávidas, proporcionando cuidados de saúde adequados. Eu não quero que isso seja uma desculpa que elas usem para criar um obstáculo legal” 207.

O Centro Yarl's Wood, assim como o centro Verne, foram alvos de críticas por parte da entidade HMIP $^{208}$. O centro Yarl's foi considerado como uma questão “de interesse nacional”, devido à gravidade dos problemas. O Centro Verne é uma antiga prisão e é criticada por implementar um "regime de incentivos punitivistas” e segregação de pessoas com saúde mental fragilizada. Sem falar em restrições ao direito de movimento, uso de arames farpados e cercas excessivas na parte interior. Há também registro de altos níveis de violência, disponibilidade de drogas e álcool, dificuldade para obter representação legal, dentro outros. Foi registrada a detenção de uma pessoa por mais de cinco anos e já são 40 pessoas detidas há mais de um ano. O relatório registrou também o suicídio de um detento.

Sobre o centro Yarl's Wood, as críticas são ainda mais duras. Não se trata de um pequeno centro: ele abrigava 354 pessoas no momento da inspeção. Houve relatos de abuso sexual ou contato indevido por parte das mulheres detidas. O relatório apontou a existência de 99 mulheres grávidas, em contrariedade às diretrizes. Há ainda relatos de violência cometidos pelos funcionários. Uma mulher que declarou ser vítima de estupro não foi liberada da detenção, sob alegação de que “estupro não é tortura”, logo, não havia motivos para sua liberação. Do total de presas durante o ano de 2015, 894 mulheres foram liberadas, depois de passar meses em detenção ${ }^{209}$.

Na França, onde refugiados, migrantes e terrorismo são temas que andam juntos nos discursos dos políticos, a guerra contra o terrorismo significa também

\footnotetext{
207 "Home Office to compensate pregnant asylum seeker for unlawful detention”.Free Movement. Colyn Yeo. 06/10/2015. (Disponível em https://www.freemovement.org.uk/home-office-tocompensate-pregnant-asylum-seeker-for-unlawful-detention/). (Último acesso em 25/01/2016). E também no site do Parlamento (Disponível em http://www.publications.parliament.uk/pa/cm201314/cmhansrd/cm130905/debtext/1309050004.htm\#13090545000176). (Último acesso em 25/01/2016).

${ }^{208}$ Her Majesty's Inspectorate of Prisons.

209 "Damning oficial reports on The Verne and Yarl's Wood Immigration Removal Centres". Free Movement. Colin Yeo. 12/08/2015. (Disponível em https://www.freemovement.org.uk/damningreports-on-the-verne-and-yarls-wood-immigration-removal-centres/). Os relatórios elaborados pela HM Chief Inspector of Prisons estão disponíveis no site "Criminal Justice Inspectorates", do governo britânico (https://www.justiceinspectorates.gov.uk/hmiprisons/wpcontent/uploads/sites/4/2015/08/The-Verne-web-2015.pdf http://www.justiceinspectorates.gov.uk/hmiprisons/wp-content/uploads/sites/4/2015/08/YarlsWood-web-2015.pdf). (Último acesso em 25/01/2016).
} 
declaração de estado de emergência, com ampliação dos poderes de polícia e de medidas excepcionais. Da Suécia até Macedônia, os países adotaram medidas emergências de controles de fronteiras, incluindo, principalmente nos países do leste, construção de barreiras e cercas, altamente militarizadas.

Logo após o ataque em Novembro ${ }^{210}$, as autoridades francesas determinaram a criação de 132 pontos de controles e aumentaram os recursos para as ações de combate ao terrorismo, adicionando 9.500 pessoas às forças de segurança, alocando 10 mil soldados. Além disso, o Presidente Hollande, no contexto de estado de emergência, propôs uma emenda constitucional que determina a perda de nacionalidade para pessoas condenadas por terrorismo, mesmo para as nascidas na França, e ainda a criminalização do acesso a websites jihadistas e fechamento de mesquitas consideradas radicais.

A partir de 2015, a Hungria, então liderada por um Primeiro Ministro de direita, Viktor Orban, e enfrentando uma crise econômica severa, determinou a construção de cercas na fronteira com Servia e Croácia. Helicópteros e policiais com cães faziam a patrulha. Em setembro de 2015, a fronteira com a Sérvia foi fechada e um mês depois a fronteira com a Croácia também, seguida da repressão e prisão de refugiados e migrantes.

Em seguida, Eslovênia e Áustria começaram a construção de cercas, assim como a Macedônia, que militarizou a fronteira com a Grécia. Bulgária, então, decidiu vigiar a fronteira com a Turquia. Acusações de agressões, roubos e outros tipos de violência contra os refugiados e migrantes eram comuns, incluindo ataques de cães incitados pelos policiais.

Ao mesmo tempo, a Frontex vigiava as águas da fronteira europeia, com recursos cada vez maiores. Foram relatados vários incidentes violentos contra os refugiados e migrantes pela Human Rights Watch, incluindo ataques realizados por homens mascarados. Neste mesmo período, estima-se que mais de 30 mil

\footnotetext{
${ }^{210}$ Os ataques em Paris, ocorridos em 15 de novembro de 2015, com 137 mortos, impactaram significativamente a acolhida aos refugiados e o sentimento da opinião pública em relação a eles na Europa. Houve reações imediatas em quase todos os países, com adoção de medidas emergenciais e propostas de mudanças legislativas. $\mathrm{E}$ as políticas de recepção se tornaram mais tímidas. A falta de esclarecimentos em torno do passaporte sírio dentre os objetos deixados por um dos autores do atentado - e as especulações a respeito de seu estatuto de refugiado - tencionou ainda mais os debates sobre a acolhida aos refugiados. Dentre as várias fontes disponíveis: “Ataques foram deflagrados em apenas 33 minutos”. BBC Brasil, 15/11/2015. (Disponível em http://www.bbc.com/portuguese/noticias/2015/11/151115_crono_ataques_ab) (Último acesso em 22/04/2016).
} 
solicitantes de refúgio e migrantes indocumentados foram detidos em 224 centros de detenção espalhados pela União Europeia. Atualmente, o número total de refugiados e solicitantes de refúgio detidos na Europa é desconhecido, porque os estados não divulgam informações. Relatos de violência e abuso se tornaram comuns.

No decorrer dos meses, as barreiras apenas aumentaram: pelo menos seis países europeus adotaram, em 2015, amplos controles de fronteira. Áustria, Suécia, Alemanha, Noruega (que não é membro da União Europeia), França (depois dos ataques em Paris) e Dinamarca estabeleceram controles entre suas fronteiras como modo de bloquear ou controlar o fluxo dos refugiados e migrantes. As medidas de controle colocam e dúvida o futuro da política de livre circulação entre os 26 países que compõem a área de Schengen.

Nas primeiras semanas de 2016, ao menos 35 mil pessoas cruzaram as fronteiras europeias ${ }^{211}$. Durante 2015, a União Europeia viu aproximadamente 1,5 milhões de pessoas atravessarem suas fronteiras de forma "irregular". A maior parte delas entrou pela Grécia e Itália, mas o fluxo de refugiados se desloca principalmente em direção à Alemanha e Suécia. A Comissão Europeia avalia que as medidas excepcionais de controle não violam as regras. Em março, a Comissão deve definir novas regras para as fronteiras e para os pedidos de refúgio (asilo) na Europa $^{212}$.

Nas primeiras 24 horas após a implementação dos controles em suas fronteiras com a Dinamarca, a Suécia - país que proporcionalmente recebeu o maior número de pedidos de refúgio na União Europeia -- viu a redução drástica dos pedidos de refúgio ${ }^{213}$. Em dezembro de 2015, a média era de 200 pedidos diários e após as restrições, o número caiu para cerca de cinquenta. Ao todo, durante o ano passado, a Suécia recebeu 163 mil solicitantes, o que corresponde ao dobro do ano anterior e proporcionalmente o maior da União Europeia. A

211 "Dutch PM says refugee crisis could shut down Europe's open borders for good". The Guardian. Larry Elliot e Jill Treanor. 21/01/2016. (Disponível em http://www.theguardian.com/world/2016/jan/21/dutch-pm-says-refugee-crisis-could-shut-downeuropes-open-borders-for-good). (Último acesso em 22/01/2016).

212 "Refugee crisis: Six countries in Schengen now have border checks in place". Independent. Lorne Cook . 06/01/2016. (Disponível em http://www.independent.co.uk/news/world/europe/refugee-crisis-six-countries-in-schengen-nowhave-border-checks-in-place-a6796296.html). (Último acesso em 21/01/2016).

213 "Suecia detecta un fuerte descenso de solicitudes de asilo tras los nuevos controles". El Diario. 05/01/2016. (Disponível em http://www.eldiario.es/politica/Suecia-detecta-descenso-solicitudescontroles_0_470353592.html). (Último acesso em 21/01/2016). 
Dinamarca registrou em 2015 o total de 21 mil pedidos, um terço a mais que no período passado.

\section{2}

\section{Choque de civilizações ou a civilização em choque}

As notícias sobre os ataques sexuais durante as festas de final de ano (2015), na cidade de Colônia, na Alemanha, correram pelo mundo ou, pelo menos, pelas tradicionais mídias do ocidente. Supostamente cometidos por refugiados e migrantes muçulmanos, os ataques tiveram como alvo sobretudo mulheres europeias. Embora os ataques em Colônia tenham recebido mais atenção, eles aconteceram em ao menos dez cidades europeias, a maioria na Alemanha, mas também na Áustria, Suíça, Suécia e Finlândia, o que leva a crer que tenham sido articulados.

Os ataques foram divulgados dentro do clima de "invasão islâmica” na Europa. Um total de 347 acusações por agressões sexuais foi registrado durante o Ano Novo em Colônia. Ao todo, 751 pessoas apresentaram 676 queixas relativas a diversos crimes, dentre os quais, 347 acusações de agressão sexual ${ }^{214}$. Estima-se que pelo menos 350 crimes sexuais aconteceram em Colônia e Hamburgo. Os criminosos, segundo declarações feitas nas mídias, eram homens com feições árabes ou norte-africanas. Apenas 32 pessoas foram identificadas pela polícia e, destes, 22 foram identificados como solicitantes de refúgio (asilo). Há ainda dois alemães e um cidadão americano entre os agressores identificados.

A questão se torna complexa quando o contexto atual na Europa é de uma grave crise de "migrantes" e ganha contornos ainda mais delicados quando colocada ao lado dos brutais assassinatos em Paris. O primeiro fato digno de nota é que a população muçulmana na Europa é proporcionalmente significativa e há tendências de crescimento para as próximas décadas. Alemanha e França possuem as maiores populações de muçulmanos dentre os países da União Europeia. São cerca de 4,8 milhões na Alemanha, o que corresponde a 5,8\% da população, e 4,7

214 "Cologne attacks: American woman tells how Syrian refugees rescued her from New Year's Eve sexual assault”. Lizzie Dearden. The Independent. 16/01/2016. (Disponível em http://www.independent.co.uk/news/world/europe/cologne-attacks-american-woman-tells-howsyrian-refugees-rescued-her-from-new-years-eve-sexual-a6816221.html). Último acesso em 20/01/2016. 
milhões na França, correspondendo a 7,5\% do total. Reino Unido tem 2,9 milhões e Itália 2,2 milhões ${ }^{215}$.

O segundo fato, é que o recente fluxo de refugiados e migrantes tende a desestabilizar a percepção real sobre o contingente de pessoas e seu perfil e tem sido, ao menos nos últimos meses, reportado como uma crise com potencial de provocar ou maximizar outras crises. De qualquer modo, a tendência em retratar os muçulmanos como signo de ameaça - à identidade europeia e cada vez mais à segurança dos europeus - não é nova, mas ganha intensidades inéditas.

Protestos de grupos de extrema-direita com bandeiras “anti Islã”, como o Pegida $^{216}$ e $\mathrm{HoGeSa}^{217}$ fizeram demonstrações em várias partes do país. Ao mesmo tempo, vários protestos “anti-fascistas” ou em recepção aos refugiados marcou também a vida dos alemães. Em Colônia, onze refugiados foram atacados por militantes de extrema-direita, enquanto em Leipzig, eles promoveram atos de depredação contra estabelecimentos identificados como árabes e muçulmanos. Dois paquistaneses, dois sírios e um grupo de africanos estão entre as vítimas de agressões identificadas em Colônia. Em Leipzig, o grupo Legida - filial do movimento anti-muçulmano Pegida - promoveu ataques contra árabes e muçulmanos, como forma de intimidação.

Pesquisas apontaram então recuo significativo da opinião pública em relação aos refugiados: em novembro de 2015, metade dos entrevistados achava que o número de solicitantes de refúgio no país era muito alto. Em janeiro, passado o Ano Novo, as notícias sobre os ataques sexuais aumentaram a rejeição para $62 \%{ }^{218}$. Angela Merkel tem sido alvo de severas críticas depois que as suas

\footnotetext{
${ }^{215}$ Em números absolutos, a Rússia, com 14 milhões de muçulmanos, tem a maior população do continente. De 1990 para 2010, a porcentagem de muçulmanos na Europa cresceu de 4 para 6\%. Uma pesquisa realizada em alguns países europeus revela que na França, Reino Unido e Alemanha, há uma visão favorável a respeito dos muçulmanos, de modo geral. Na Itália e na Polônia, de modo geral, a visão é negativa " 5 facts about the Muslim population in Europe". Pew Research Center. Conrad Hackett. Novembro/2015. (Disponível em http://www.pewresearch.org/fact-tank/2015/11/17/5-facts-about-the-muslim-population-ineurope/). (Último acesso em 26/01/2016).

${ }^{216}$ Pegida, em tradução livre: "Europeus patriotas contra a Islamização do Ocidente”. Em inglês: "Patriotic Europeans Against the Islamisation of the West".

217 "Hooligans against Salafists". Nome de um movimento de extrema direita, surgido a partir dos "hooligans" na Alemanha, cujo objetivo é propor combate ao crescimento do Salafismo considerado como uma versão fundamentalista radical do Islamismo -- na Alemanha.

218 "Cologne attacks: Support for refugees in Germany falling amid far-right protests and vigilante attacks”. Lizzie Darden. 13/01/2016. The Independent. Disponível em http://www.independent.co.uk/news/world/europe/cologne-attacks-support-for-refugees-in-
} 
medidas abriram o país para a recepção a cerca de 1,1 milhão de pessoas, entre refugiados, solicitantes de refúgio e migrantes. Em razão de sua posição frente à crise dos refugiados, Merkel foi considerada pela revista Time a "personalidade do ano" de $2015^{219}$.

Seu slogan “nós podemos fazer isso agora” perdeu força logo na sequência das críticas, quando o governo alemão reintroduziu maiores controles na fronteira e passou a enviar centenas de refugiados de volta à Áustria. Ao lado das restrições, Merkel propôs novas medidas para negar o direito de refúgio (asilo) para os acusados por crimes. Outra alteração, considerada positiva, dispensa as vítimas de ataques sexuais de provar que resistiram ao agressor. Esta mudança é uma antiga reinvindicação dos movimentos feministas e foi preciso esperar pela "racialização" do crime para que algo de fato se tornasse concreto. A segunda alteração diz respeito à deportação dos acusados por tais crimes. No entanto, a medida restringe antigos direitos dos solicitantes de asilo e evidentemente contraria a Convenção de $1951^{220}$.

A relação entre crimes sexuais, migração e refugiados ganha consistência e o limite da tolerância em algumas cidades alemãs, como em Colônia, parecem chegar a um ponto crítico. Não faltam críticos que apontam o fracasso do "multiculturalismo" e das políticas de integração ou ainda que exigem formas mais rigorosas de "integração" e "assimilação”, como, por exemplo, acontece na Bélgica, onde há aulas para se aprender a "respeitar as mulheres”.

No Reino Unido, há propostas de “integração” no mesmo sentido. Em janeiro de 2016, em visita a uma mesquita, o Primeiro-Ministro Britânico, David Cameron, anunciou que colocará em vigência planos para encorajar a integração das mulheres muçulmanas. No mesmo dia, depois de afirmar que cerca de 40 mil mulheres migrantes no país não falam inglês e cerca de 190 mil falar muito mal, ele insistiu que os migrantes devem aceitar algumas obrigações, como aprender

germany-plummeting-amid-far-right-protests-and-vigilante-a6808616.html.(Último acesso em 20/01/2016).

219 "Angela Merkel: The quote that sums up why the German Chancellor was named TIME 'Person of the Year'”. Time. 09/12/2015. Disponível em http://www.independent.co.uk/news/people/angela-merkel-the-one-quote-that-sums-up-why-thegerman-chancellor-was-named-time-person-of-the-year-a6766556.html. (Último acesso em 20/01/2016).

220 "What the Cologne attacks tell us about Europe". Daniel Renwick. Middle East Eye. 18/01/2016. (Disponível em http://www.middleeasteye.net/columns/muslims-cologne-and-futureeurope-1504380542). (Último acesso em 18/01/2016). 
inglês, como condição de integração e como forma de contribuição com o crescimento do país ${ }^{221}$. E, enfim, advertiu que os migrantes que falharem nos testes de idioma, depois de dois anos e meio no Reino Unido, podem ser forçados a deixar o país.

Segundo Cameron, é preciso acabar com a "tolerância passiva” à separação das comunidades, que deixam as mulheres muçulmanas vulneráveis a discriminação e isolamento social. Em suas palavras, "nós nunca realmente construiremos Uma Nação, a menos que sejamos mais assertivos quanto aos nossos valores liberais, mais claros quanto às expectativas que colocamos sobre aqueles que vêm morar aqui”. Cameron foi criticado por ter escolhido como foco a dificuldade de integração das mulheres muçulmanas, já que há, por exemplo, um número considerável de mulheres iraquianas cristãs que enfrentam problemas semelhantes ${ }^{222}$.

Logo depois que os ataques em Colônia e outras cidades ganhou publicidade, o presidente do Departamento Federal de Investigações da Alemanha, Holger Munch, revelou o aumento de crimes em abrigos para refugiados. A quantidade de delitos, segundo sua declaração, é pequena e que a criminalidade não tem aumentado de forma proporcional à chegada de refugiados $^{223}$. A reação dos políticos e dos grupos de direita já era esperada e, de certo modo, os ataques vieram bem a calhar, justamente no momento em que faltava ao governo dos países europeus a desculpa necessária para acabar de vez com a "crise dos refugiados".

Para as mulheres que foram vítimas dos ataques ou que se sentem inseguras, a resposta das autoridades não foi melhor. A prefeita (Democrata-Cristã) de

221 Davida Cameron também explicou que não estava se referindo apenas às mulheres muçulmanas, mas a todas que entraram no país com vistos garantidos pelo casamento. E que a medida não era uma forma de culpar as mulheres que não falam inglês, porque, como ele disse, "algumas destas pessoas vêm de sociedades patriarcais e talvez os homens não queiram que elas aprendam inglês". O plano de incentivo inclui o investimento de 20 milhões de libras para ajudar as mulheres muçulmanas a aprender inglês. "Cameron: migrants on spousal visas may have to leave if English doesn't improve” Entrevista com David Cameron. The Guardian. Andrew Sparrow. 18/01/16.(http://www.theguardian.com/politics/blog/live/2016/jan/18/david-cameronstoday-interview-politics-live). (Último acesso em 18/01/2016).

222 "Migrant spouses who fail English test may have to leave UK, says Cameron". The Guardian. Rowena Mason and Harriet Sherwood. 18/01/2016. (Disponível em http://www.theguardian.com/uk-news/2016/jan/18/pm-migrant-spouses-who-fail-english-testmay-have-to-leave-uk). (Último acesso em 18/01/2016).

${ }^{223}$ "Refugados e violência: os dois lados". DW. 26/02/1016. (Disponível em http://www.dw.com/pt/refugiados-e-viol\%C3\%AAncia-os-dois-lados/a-18985827). （Último acesso em 26/01/2016). 
Colônia sugere às mulheres eu se adaptem à nova situação, afastando-se dos homens (“a um braço de distância”) e não saindo sozinhas de casa. O ônus, como denunciam as mulheres, recai novamente sobre elas.

De outro lado, a defesa intransigente dos migrantes e refugiados não apenas se mostra ineficaz, mas também traz graves perigos. Evidentemente, todos que se preocupam com os refugiados e migrantes sabem dos estigmas e das formas mais ou menos violentas como eles são discriminados, especialmente aqueles que se enquadram na imagem caricatural de árabes e muçulmanos. O fato, porém é que há evidencias fortes de que os ataques foram planejados. E que as mulheres tenham sido vítimas, isso não deixa de ser revelador.

De certo modo, os ataques em Colônia contra as mulheres estão em sintonia com os ataques em Paris: eles se voltam justamente contra o que há de mais progressista nas cidades europeias. Abandonar à própria sorte as conquistas que cidades como Colônia e Paris foram capazes de conseguir, não apenas para as mulheres, mas também para toda a diversidade de vidas, é deixar aberto o caminho para que a única resposta possível aos fundamentalistas seja a extremadireita $^{224}$.

Na Europa - o território geográfico, político e também subjetivo -- a eleição do islamismo radical e do terrorista muçulmano como o grande perigo funciona para justificar a indiferença em relação aos refugiados e migrantes, com a criação de todas as medidas e territórios de exceção, incluindo os centros de detenção e as fronteiras terceirizadas. Na luta especular entre o ódio ocidental ao radicalismo islâmico e o ódio islâmico contra o ocidente, a estranha convergência é o ataque à heterogeneidade e à democracia.

Não é apenas o alarme securitário que dispara, mas também o temor de desaparecimento da "identidade" cultural. O risco à segurança e à estabilidade identitária justifica as medidas restritivas na França (contra o véu e contra as mesquitas) e no Reino Unido (obrigatoriedade de idioma inglês), por exemplo. Ao final, é também de crise de soberania que se trata.

\footnotetext{
224 "Os ataques machistas coordenados em Colônia e os erros eurocêntricos de uma esquerda europeia pós-laica”. Marieme Hélie-Lucas. Passa Palavra. 24/01/2016. (Disponível em http://www.passapalavra.info/2016/01/107395). (Último acesso em 26/01/2016).
} 
É desta relação especular que saem insumos para uma gestão sobre a imagem dos refugiados e migrantes, que será distribuída globalmente. Neste sentido, a Europa não é apenas um território, mas uma subjetivação, um modo de vida e de gestão política. E se o Congo ou o Haiti estão em toda parte, como ameaças ou como devires, a Europa igualmente sucede pelos mesmos processos de desterritorialização e territorialização. 


\section{O Congo como paradigma: no coração das trevas.}

“O Congo, outra vez. O Congo, em toda parte”.

Roger Casement ${ }^{225}$.

A guerra é a condição afinal em que vivemos e em que se constituem nossas subjetividades. Queiramos ou não, a guerra é nosso campo de trabalho e de vida. A crise dos refugiados é o nome da terrível violência que se move contra a parte mais pobre do planeta, provando que se o poder investe sobretudo na vida, ele nunca abdicou de decidir a morte. A guerra continua sendo um modo de gestão e não apenas a continuação da política em outros termos.

Pelas palavras - e pela fuga - dos refugiados, sabemos que a guerra passou para dentro das fronteiras de cada estado, variando de intensidade, ora na forma típica de confronto militar, ora como intervenção humanitária ou simplemente na forma de arbitrariedade policial. Seja como for, a guerra está espalhada e nunca diz respeito a um só estado ou povo. Ela não apenas perpassa as relações sociais, na forma de violências diversas, como ativa todos os pontos de conflito. E persegue os refugiados como um feitiço, para onde quer que fujam. A guerra é também nômade.

Neste sentido, as guerras na República Democrática do Congo se tornam emblemática do que queremos dizer: entre a governabilidade e o massacre não há exatamente uma fronteira de separação, mas formas de gestão que se comunicam. No regime contemporâneo do biopoder, em que a vida é o lugar por excelência do investimento do poder, e a sobrevivência da espécie integra os seus cálculos, os massagres e genocídios se tornaram comum.

\footnotetext{
${ }^{225}$ Frase atribuída ao personagem do romance histórico “O Sonho do Celta”, de Mario Vargas Llosa, inspirado na vida do agente diplomático de origem irlandesa, Roger Casement, que, a serviço do Império Britânico, conheceu a violência da colonização europeia na África e na América do Sul, no início do século XX. Ele se tornou, mais tarde, ativista pela libertação da Irlanda. E acabou preso, julgado e condenado a morte, pelo crime de traição. (LLOSA, Mario Vargas. O sonho do Celta. Rio de Janeiro: Objetiva, 2011.)
} 
O Congo se torna uma das tristes ilusraçõs e mesmo um dos grandes paradigmas da atual crise dos refugiados, primeiro porque expõe a nudez dos corpos dilacerados numa das mais longas e terríveis guerras da história atual, e, mais importante, porque demonstra que a o Congo está em todo lugar.

\section{1}

\section{A diáspora e a possibilidade de lutar}

O massacre de cerca de 500 pessoas em Beni, em maio de 2016, seria mais um dentre tantos outros já noticiados na República Democrática do Congo, se não fosse uma grande mobilização realizada principalmente pelos congoleses exilados $^{226}$. A diáspora congolesa foi capaz de unificar sua indignação diante das terríveis mortes em Beni, prestando suporte a manifestantes que protestavam na capital Kinshasa, incluindo os ativistas que promoveram uma manifestação em frente à base da Missão da ONU no Congo (MONUSCO) ${ }^{227}$.

O terrível nos massacres não é apenas o grande número de vítimas ou o fato de que existam crianças entre elas, mas também a crueldade dos atos, em que a intensidade de terror é mais importante do que a extensão do extermínio. A longa guerra no Congo não cessa de proporcionar barbaridades infinitas e inimagináveis: mais uma vez, desde Burundi, Ruanda e como já havia sido antes em Beni, homens, mulheres e crianças foram mortas a golpes de facas e machados, degolados em casa ou nas ruas.

Os congoleses que vivem em outras partes do mundo, principalmente na Europa, são atores importantes na luta pela democracia no país, a despeito das várias diferenças entre eles. Primeiro, pelo esvaziamento que a diáspora provoca e, segundo, porque é possível manifestar oposição publicamente sem correr o risco de assassinato, prisão ou tortura. A diáspora congolesa é composta por uma população estimada entre 2 a 7 milhões de pessoas espalhadas pelo mundo e a

226 “La Monusco pilonne des positions des ADF à Beni”. Radio Okapi. 18/05/2016. (Disponível em http://www.radiookapi.net/2016/05/18/actualite/securite/la-monusco-pilonne-des-positionsdes-adf-beni). (Último acesso em 26/05/2016).

${ }^{227}$ MONUSCO, a Missão da ONU no Congo (em inglês, United Nations Organization Missin in Democratic Repblic of the Congo), foi estabelecida pelo Conselho de Segurança das Nações Unidas, por meio da Resolução 1279, em novembro de 1999, e estendida até pelo menos março de 2017, nos termos da Resolução 2277, especialmente por razão das eleições previstas no país. Informações disponíveis no site da Monusco (https://monusco.unmissions.org/en/timeline) (Último aceso em 28/05/2016). 
remessa de dinheiro enviada à República Democrática do Congo pela diáspora representa a primeira fonte de receitas, maior que qualquer tipo de assistência internacional.

Grande parte das remessas partem da França, Estados Unidos da América, Alemanha, Bélgica, Suíça e Reino Unido e são usadas para a educação das crianças, construção de casas ou para financiar a viagem dos que ficaram para trás. Parte do dinheiro, contudo, não é reconhecido, porque circula em circuitos paralelos ao meio oficial. Em 2011, as remessas representaram US\$ 9 bilhões, cerca de $45 \%$ do PIB do país ${ }^{228}$.

Desta vez, a diáspora também foi responsável por lançar luz sobre o que acontece em Beni e também por mostrar o que acontece com os jovens que lutam pelo fim da violência no país. Não é a primeira vez que a população de Beni - na Província de Kivu-Norte, próximo à fronteira com Uganda - é vítima de um ataque como este. No último ataque registrado, no final de 2014, 256 pessoas foram mortas a golpes de facões, incluindo crianças, e seus corpos lançados em valas comuns $^{229}$. E esta não foi sequer a primeira vez que o grupo de origem ugandense, conhecido como $\mathrm{ADF} \mathrm{Nalu}^{230}$, ataca a região.

Beni, como muitas cidades do leste do país é alvo de constantes ataques por parte do grupo, e conta com o silêncio e conivência das forças de segurança do

228 “RDC: plus de 9 milliards USD envoyés par 'les congolais de la diaspora' en 2011”. Afrique Kongotimes. 08/11/2012. (Disponível em http://afrique.kongotimes.info/rdc/diaspora/5186-congomilliards-usd-envoyes-congolais-diaspora-2011.html). E também "La diáspora congolaise génère la moitié du PIB du pays mais reste ignorée”. Financial Afrik. (Último acesso em 13/06/2016). Christian Kazmba. 22/12/2015. (Disponível em http://www.financialafrik.com/2015/12/22/ladiaspora-congolaise-genere-la-moitie-du-pib-du-pays-mais-reste-ignoree/\#.V16PlrsrLIU) (Último acesso em 13/06/2016).

229 "Políticos denunciam massacre na República Democrática do Congo". G1 (Fonte: France Presse). 24/11/2014. (Disponível em http://g1.globo.com/mundo/noticia/2014/11/politicosdenunciam-massacre-na-republica-democratica-do-congo.html) (Último acesso em 26/05/2016).

${ }^{230}$ O grupo ADF Nalu ("Forças Democráticas Aliadas” Nalu) é um grupo rebelde de oposição com base em Uganda, formado por exilados ugandenses que pretendiam derrubar o governo. Além da base no oeste de Uganda, o grupo tem bases também na RDC, especialmente na região leste de Kivu Norte, pelo menos desde os anos 1990. Trata-se de um grupo islâmico armado, considerado um dos mais antigos em ação no leste do Congo, e também o mais enigmático. Os ataques do Boko Haram na Nigéria despertaram o interesse para os grupos islâmicos na África, porém, o ADF continua agindo sem grande repercussão, apesar de duas décadas de terror. A longa vida do grupo é atribuída à sua capacidade de manter-se imperceptível, à sua forte estrutura interna (que inclui serviços médicos, e justiça baseada na sharia e de educação) e externa (através de redes internacionais com outros grupos, que garantem suprimentos, roupas, armas e dinheiro, inclusive com apoiadores situados em Londres) e também por suas ligações com as forças armadas do Congo e com influentes políticos locais, que garantem sua impunidade. "New insights on Congo's islamists rebels”. The Washingon Post. 19/02/2015. (Disponível em https://www.washingtonpost.com/blogs/monkey-cage/wp/2015/02/19/new-insights-on-congosislamist-rebels/) (Último acesso em 26/05/2016). 
país. Pelo menos mil pessoas já foram mortas ${ }^{231}$ nos últimos dois anos e 88 mil pessoas deixaram a região em razão da violência, segundo informações do ACNUR $^{232}$.

Ativistas do grupo "LUCHA” (“Luta por mudança”, em tradução livre) se colocaram em frente à sede da MONUSCO, em Goma, capital da província de Kivu Norte, para denunciar os massacres em Beni, região que permanece vulnerável à violência e instabilidade por mais de duas décadas ${ }^{233}$. Ao mesmo tempo em que pedem a imediata intervenção da força militar da ONU, os ativistas reclamam do absoluto silêncio do Presidente Joseph Kabila e das autoridades. Desta vez, os ativistas não estão sós, mas acompanhados de manifestações dos congoleses de todo o país -- independentemente de sua identidade étnica ou filiação política - de personalidades conhecidas e também dos expatriados espalhados pelo mundo, dos Estados Unidos da América até França, passando pelo Brasil. A onda de indignação se alastrou pelas redes sociais rapidamente e de forma inédita.

Novas manifestações e protestos foram realizados, incluindo a conclamação de greve feita por mulheres em Butembo. Seguindo a estratégia de comunicação utilizada após os ataques à revista “Charlie Hebdo” ${ }^{234}$, as redes passaram a adotar o enunciado “\#JeSuisBeni” ou “\#Justice4Beni” e perfis no Facebook ganharam a bandeira do país. E um manifesto, com mais de 14 mil assinaturas, corre pelo mundo, com o objetivo de tornar pública a gravidade da violência em Beni.

No entanto, a despeito do caráter pacífico e justo das manifestações, a polícia congolesa, como de praxe, reprimiu violentamente a manifestação que ativistas faziam em frente à sede da MONUSCO, em Goma. Oito pessoas ficaram

231 “La Monusco pilonne des positions des ADF à Beni”. Radio Okapi. 18/05/2016. (Disponível em http://www.radiookapi.net/2016/05/18/actualite/securite/la-monusco-pilonne-des-positionsdes-adf-beni). (Último acesso em 26/05/2016).

232 "UNHCR condemns massacres in Beni, in DRC Congo and calls for humanitarian access" UNHCR. 19/12/2014. $\quad$ (Disponível em http://www.unhcr.org/news/briefing/2014/12/54940cae6/unhcr-condemns-massacres-beni-drcongo-calls-humanitarian-access.html) (Último acesso em 26/05/2014).

233 “\#JesusBeni: les Congolais mobilisés pour em finir avec les massacres au Kivu”.Le Monde Afrique. 17/05/2016. (Disponível em http://www.lemonde.fr/afrique/article/2016/05/17/jesuisbeniles-congolais-mobilises-pour-en-finir-avec-les-massacres-au-kivu_4921091_3212.html) (Último acesso em 26/05/2016).

${ }^{234}$ Trata-se do ataque realizado em 07 de janeiro de 2015 a membros da revista Charlie Hebdo, em Paris, que causou 11 vítimas fatais e mais 11 feridos. $\mathrm{O}$ ataque foi reivindicado pelo grupo $\mathrm{Al}$ Qaeda. Informações sobre o caso podem ser encontradas em "Charlie Hebdo attack: three days of terror”. BBC News. 14/01/2015. (Disponível em http://www.bbc.com/news/world-europe30708237) (Último acesso em 26/05/2016). 
feridas, incluindo um funcionário da ONU que tentava registrar o ataque policial $^{235}$. A repressão policial acontece no contexto de severa restrição de liberdades políticas e civis no país, onde é comum a prisão arbitrária de opositores - mesmo ocasionais - e uso de força letal contra manifestantes. Pelo menos quatro ativistas do grupo LUCHA foram presos por causa de sua participação na manifestação.

E antes disso, 18 haviam sido interpelados pela justiça congolesa depois de uma grande manifestação pela liberdade de dois jovens que estão presos há mais de um ano por causa de seu ativismo. A prisão arbitrária de Fred Bauma e Yves Makwambala ficou famosa graças à divulgação que o grupo conseguiu nas redes e atualmente as grandes organizações internacionais de direitos humanos fazem parte da campanha ${ }^{236}$.

A MONUSCO - que durante dois anos e meio teve um comandante brasileiro com experiência prévia no Haiti ${ }^{237}$-- e as forças armadas congolesas responderam às manifestações, mobilizando tropas em Beni. As forças armadas lançaram a operação denominada "Usalama” (que, em suaíli significa “segurança”) ${ }^{238}$ e apesar do atraso, a presença militar na região é vista como uma vitória da mobilização dos ativistas.

235 "RDC: 4 activistes de la Lucha arrêtés lors des manifestations contre les massacres de Beni". Congo $\quad$ Forum. 14/05/2016. (Disponível em http://www.congoforum.be/fr/nieuwsdetail.asp?subitem=1\&newsid=204558\&Actualiteit=selected ) (Último acesso em 26/05/2016).

${ }^{236}$ Informações sobre a campanha em torno da libertação de Fred Bauma e Yves Makwambala podem ser encontradas na página do grupo Lucha (http://www.luchacongo.org/nosactions/freefred/qui-est-fred/) e na página da organização Human Rights Watch ("DR Congo: Free youth activists". HRW. 15/05/2016, disponível em https://www.hrw.org/news/2016/03/15/drcongo-free-youth-activists). Uma entrevista com Fred Bauma pode ser lida na página da revista Pambazuka News (Lucha: yout movement in Congo demands social justice", 30/10/2014.Disponível em http://www.pambazuka.org/governance/lucha-youth-movement-congodemands-social-justice) (Último acesso em 26/05/2016). Atribui-se a liberação dos ativistas à enorme pressão que ativistas congoleses e órgãos internacionais fizeram sobre o governo da RDC. 237 "Descrédito da ONU e violência rebelde aguardam general brasileiro no Congo". DW. 08/05/2013. (Disponível em http://www.dw.com/pt/descr\%C3\%A9dito-da-onu-eviol\%C3\%AAncia-rebelde-aguardam-general-brasileiro-no-congo/a-16790658) (Último acesso em 28/05/2016).

238 "Beni: les FARDC et la MONUSCO lancent l'operation 'Usalama' contre les ADF". 15/05/2016. Congo $\quad$ Forum. $\quad$ Disponível em http://www.congoforum.be/fr/nieuwsdetail.asp?subitem=1\&newsid=204563\&Actualiteit=selected ) (Último acesso em 26/05/2016). 


\section{2}

\section{Repressão política e opressão}

A repressão policial às manifestações pacíficas dos jovens em Goma se dá dentro de um contexto geral de grave tensão política no país. Antes da repercussão positiva em torno de Beni, poucos acreditavam que manifestações teriam alguns resultados, dado o nível de repressão no país. A situação no país tornou-se ainda mais tensa por causa das manobras que o atual Presidente Kabila tem levado adiante para prorrogar seu mandato. Há vários indícios de que o ano de 2016 será terrível para a população do país.

Em janeiro de 2015, manifestantes tomaram as ruas da capital e de outras cidades para mostrar oposição ao um projeto de lei que estenderia a permanência de Kabila no poder, extrapolando o mandato que termina em 2016. A proposta do governo consistia em convocar um censo eleitoral para organizar os assentos parlamentares, o que levaria anos para ser realizado. A oposição, por sua vez, temia que durante este tempo Kabila modificasse a constituição para então concorrer a um terceiro mandato.

A manobra de Kabila foi cancelada, mas a oposição afirma que esta foi apenas uma das suas tentativas de atrasar as eleições. Outra estratégia é prejudicar o funcionamento da Comissão Eleitoral Nacional Independente (CENI), principalmente através do bloqueio de financiamento. Os opositores também reclamam da falta de independência da CENI, que sofre influência direta do governo. Nenhum dos membros indicados pela oposição foi nomeado para a Comissão. As perspectivas são sombrias. Se não puder participar das eleições, a oposição crê que o atual presidente Kabila vai fazer de tudo para impedi-las. A sua lógica é ou ele ou a guerra civil. Além de tudo, o governo de 21 dentre as 26 províncias do país estão sendo governadas por políticos nomeados por Kabila, no lugar dos governadores eleitos pelos legislativos provinciais.

No final de 2015, Kabila anunciou que desejava realizar um diálogo nacional para preparar o caminho para as eleições, mas não disse quando iria começar. Muitos líderes da oposição se recusaram a participar, acusando mais uma tentativa de adiar as eleições e impor manobras para mudanças constitucionais. Kabila também disse que iria conceder perdões individuais para alguns presos políticos para ajudar "restaurar a calma", mas as organizações e 
ativistas de direitos humanos reclamam uma proposta mais ampla para libertação de todos os prisioneiros detidos em razão de posicionamento político.

Depois de manobras para evitar as eleições que poderiam leva-lo a deixar o poder, Joseph Kabila, presidente desde 2001 -- sucedendo ao próprio pai -- é apontado como responsável por opor consideráveis obstáculos aos seus opositores e a qualquer iniciativa democracia no país. Alguns obstáculos são mais graves, como revelam os relatos de prisões arbitrárias de opositores, ou "menos graves”, como as intimidações que inibem os encontros dos futuros candidatos e os grupos e oposição ${ }^{239}$.

Em 19 de janeiro de 2016, grupos de oposição que tentavam chegar a um encontro em Ngiri Ngiri -- uma comuna no centro da capital Kinshasa -- tiveram que enfrentar policiais e também milicianos armados. O encontro foi marcado para lembrar um ano da morte de manifestantes de oposição pelas forças de segurança do governo: de acordo com a versão oficial, foram 27 mortos, mas para a Federação Internacional de Direitos Humanos da RDC, foram 42. E há relatos de que uma centena de militantes foi presa. O governo, por meio de seu porta-voz, justifica as prisões dizendo que havia folhetos que "convidavam a população a se rebelar contra o governo".

Ainda no começo de 2016, a polícia e Guarda Republica do país abriram fogo contra manifestantes e mataram mais de 40 pessoas em plena capital, Kinshasa, e em Goma, capital de Kivu Norte. As autoridades tentam proibir manifestações políticas em várias cidades do país, enquanto jovens ativistas, estudantes, músicos, jornalistas, líderes de partidos políticos e apoiadores são sistematicamente presos. A temida ANR -- Agência Nacional de Inteligência -realizou várias detenções sem acusação formal e sem permitir acesso a advogados ou familiares. De acordo com um relatório da "Human Rights Watch”, algumas pessoas foram levadas a julgamento por acusações politicamente motivadas ${ }^{240}$.

As prisões do país estão muito abaixo dos padrões mínimos internacionais e há registros de prisioneiros que morreram em razão das condições carcerárias.

\footnotetext{
239 “DRC's opposition pushes for elections in 2016”. Al Jazeera. William Clowes. 28/01/2016. (disponível em http://www.aljazeera.com/indepth/features/2016/01/drc-opposition-pusheselections-2016-160126064334721.html). (Último acesso em 28/01/2016).

240 “DR Congo: Free political prisoners”. Human Rights Watch. 09/12/2015. Disponível em https://www.hrw.org/news/2015/12/09/dr-congo-free-political-prisoners. (Último acesso em 26/05/2016).
} 
Além de instalações completamente inadequadas, com falta de água potável e de alimentação para os presos, há relatos de violência severa cometida por parte dos carcereiros e das forças de segurança, incluindo membros da Agência Nacional de Inteligência, conhecida pelas perseguições políticas contra opositores. Maus tratos e tortura são rotineiros.

A mais famosa das prisões do país, Makala, abriga os principais prisioneiros políticos do país. O Ministro da Justiça congolês se referiu à Makala como “casa da morte” ${ }^{241}$. Prisioneiros que conseguiram escapar relatam, além dos usuais maus tratos e espancamentos, a total falta de assistência aos presos, que, na falta de ajuda de familiares, são obrigados a se alimentar de grama ou insetos ${ }^{242}$.

\section{3}

\section{A luta por direitos humanos no Congo: a coragem da verdade}

A arbitrariedade da polícia congolesa encontra respaldo nas autoridades locais e no modo de gestão de Kabila. Quando um ativista do grupo "Lucha” foi à delegacia levar comida para os jovens presos durante a manifestação em Goma, a polícia o deteve e o interrogou durante 45 minutos, depois de agredi-lo. Em novembro de 2015, o vice-prefeito de Goma ameaçou jovens do "Lucha” de desaparecimento: “vamos leva-lo para um lugar onde ninguém será capaz de encontra-lo". Dias depois, o prefeito declarou publicamente que o "Lucha” opera em "ilegalidade total” e que os membros e apoiadores deveriam cessar as atividades destinadas a "perturbar a ordem pública” ${ }^{243}$.

Em resposta, uma coligação de 33 organizações congolesas de direitos humanos, conhecidos como a "Coligação para o respeito da Constituição", publicou uma declaração exortando o governo congolês a respeitar o direito de reuniões e manifestações pacíficas. A coalizão também expressou preocupação com os atrasos nas eleições em razão da proposta de diálogo nacional anunciado

${ }^{241}$ Mais informações podem ser encontradas no relatório da Human Rights Watch, “World Report 2013 - Democratic Republic of Congo" de 31/01/2013 (disponível em http://www.refworld.org/docid/510fb4ed3c.html) (Último acesso em 27/05/2016).

${ }^{242}$ Relato feito informalmente por alguns congoleses que saíram da prisão e se tornaram solicitantes de refúgio no Brasil, atendidos pelo Programa de Atendimento a Refugiados e Solicitantes de Refúgio da Cáritas Arquidiocesana do Rio de Janeiro.

243 “DR Congo: Free Political Prisoners". Human Rights Watch. 09/12/2015. (Disponível em https://www.hrw.org/news/2015/12/09/dr-congo-free-political-prisoners) (Último acesso em 27/05/2016). 
pelo governo e que, segundo argumentam, violaria a Constituição do Congo. Dois dias mais tarde, o Ministro das Comunicações do Congo anunciou a abertura de "inquérito administrativo" para investigar os membros da coalizão.

As manobras pela extensão de seu mandato no cargo tiveram como efeito a reunião de quase toda a oposição contra Kabila, incluindo a Igreja Católica, grupos da sociedade civil, jovens ativistas e até mesmo ex-membros da coalizão majoritária que o apoiavam. Muitos estavam engajados nos protestos no início de 2016, reivindicando planos efetivos para eleições em tempo útil.

No esforço de acalmar a tensão política em um ano eleitoral, o Ministro da Justiça de Kabila anunciou que ao menos dois mil prisioneiros seriam libertados das prisões. O ministro Alexis Thambwe comprometeu-se com a libertação de 1.200 condenados por crimes leves, que tenham cumprido parte da pena. E cerca de 800 prisioneiros deverão ser liberados após perdões concedidos por Kabila a todos os presos com mais de 70 anos e que não tenham cometido crimes graves. $\mathrm{E}$ também a membros de um movimento religioso separatista.

No entanto, organizações de direitos humanos permanecem críticas. Dolly Idefo, diretor executivo da organização "Voix des sans voix” ("Voz dos sem voz”, em tradução livre), conhecida por sua luta por direitos humanos e também pelas perseguições sofridas, disse que a libertação de prisioneiros não vai suficientemente longe: "Há presos políticos em todo o país e há pessoas que foram detidos sem qualquer decisão judicial", disse ele. O governo nega que existam presos políticos em suas prisões, conhecidas pela superlotação, pelos maus tratos e tortura ${ }^{244}$. Anos atrás, Floribert Chebeya, o líder da "Vois des sans voix", conhecido defensor de direitos humanos, reconhecido por sua luta contra a ditadura do ex-presidente Mobutu, foi encontrado morto, em junho de 2010, e quatro policiais foram condenados a morte pelo crime, depois de intensa pressão internacional $^{245}$.

244 “Update 1 - Congo to release 2,000 prisoners in January”. Reuters. Aaron Ross. 05/01/2016. (Disponível em http:/www.reuters.com/article/congodemocratic-justiceidUSL8N14P1Q520160105) (Último acesso em 27/05/2016). Sobre torturas nas prisões congolesas, há informações no relatório "Rape as torture in the RDC: sexual violence beyond the conflict zone", da "Freedom from torture", de junho e 2014 (disponível em http://www.refworld.org/docid/539814554.html) (Último acesso em 27/05/2016).

245 “DR Congo: Floribert Chebeya killers sentenced to death”. BBC News. 23/06/2011. (Disponível em http://www.bbc.com/news/world-africa-13895771) (Último acesso em 28/05/2016). 
A perseguição a opositores, ainda lhe sejam atribuídas esta qualidade, é uma prática que acompanha todo o mandato do Presidente Kabila, desde sua chegada ao poder em 2001 e, antes dele, também a gestão de seu pai Laurent Kabila. Qualquer pessoa ou grupo que desafie seu plano de se manter no poder certamente se tornará alvo de perseguição injusta e arbitrária.

\section{4}

\section{Ciclos de uma guerra sem fim}

A violência no Congo é parte de uma guerra que atinge todo o país, mas de modos distintos. De uma parte, perseguição a opositores, prisão de jornalistas e fraudes nas eleições. De outro, é a mais brutal das guerras: mulheres tornadas escravas, submetidas a estupros coletivos, durante meses; crianças transformadas em cruéis soldados; canibalismo forçado, mutilações, e uma infinidade de brutalidades. Mães obrigadas a matar seus próprios filhos em pilões de triturar grãos. Fatos que nem sequer foram noticiados, mas que fazem parte do testemunho perdido dos refugiados, como em tantos outros massacres.

Parece inexplicável que uma guerra como esta aconteça, mas ela acontece há décadas. Em parte, podemos compreender esta guerra como produto do ódio entre etnias - num país em que convivem cerca de 200 diferentes etnias -- que disputam as riquezas do solo, o mais rico em recursos naturais de toda a África subsaariana, e que tem sido objeto de confiscos e disputas desde a colonização belga. E das quais a população congolesa não apenas está distante como ainda é extraída graças à exploração de sua força, em trabalhos pesados e perigosos. Para que, ao final, sejam levadas em contrabando para os países vizinhos ou comercializadas para grandes empresas, quase sempre por vias ilegais, enriquecendo os grupos que garantem a continuidade da guerra como forma de gestão $^{246}$.

O Congo é estrategicamente interessante por sua localização, pela riqueza de seu subsolo -- foi dele, aliás, que saiu o urânio utilizado na bomba de Hiroshima e de onde sai o coltan utilizado hoje em grande parte dos aparelhos

\footnotetext{
246 "Congo: a maior guerra do mundo". Adriana Carranca. Estadão. 20/10/2013 (Disponível em http://internacional.estadao.com.br/noticias/geral,congo-a-maior-guerra-do-mundo-imp-,1087710) (Último acesso em 27/05/2013).
} 
eletrônicos de comunicação - contudo, é também importante como uma das expressões da guerra global no território africano. O Congo é um dos territórios livres para as guerras de alta intensidade, que não são outra coisa que não a outra face da gestão e da governabilidade, preservando, contudo, a identidade de alguns dos grandes atores, à custa da indiferença quanto às vítimas.

A guerra na República Democrática do Congo não é apenas longa, mas extremamente complexa quanto às suas causas e aos seus desdobramentos. Ela pode ser explicada, em parte, pelo ódio entre etnias que disputam as riquezas do solo, o mais rico em recursos naturais de toda a África subsaariana, e que tem sido objeto de confiscos e disputas desde a colonização belga. A população, no entanto, não apenas está distante da riqueza como ainda é explorada em trabalhos pesados e perigosos para que elas sejam levadas em contrabando para os países vizinhos ou comercializadas para grandes empresas, quase sempre por vias ilegais $^{247}$.

A rivalidade étnica, contudo, não explica o conflito, se não se consideram as suas razões históricas e políticas. Depois de sua independência da Bélgica, em 1960 - e após ter sido parte do patrimônio pessoal do Rei Leopoldo II - o país enfrentou uma grave crise. Grupos situados em Katanga pretendiam a separação do país, motivada, sobretudo, pelas riquezas minerais que ainda hoje são cobiçadas e deixaram a região extremamente vulnerável à violência ${ }^{248}$.

Em um golpe de estado, Joseph Mobutu, que depois seria conhecido por Mobuto Sese Seko, tomou o poder, na sequência da morte de Patrice Lumumba considerado líder heroico da independência do país e o primeiro-ministro em sua estreia como democracia -- alterando o nome do país para Zaire. Lumumba havia solicitado apoio à antiga União Soviética para lidar com os separatistas de Katanga e o golpe levado adiante por Mobutu, no contexto da divisão bipolar dos anos 1960, teve apoio da Bélgica e dos Estados Unidos da América. Seu discurso no ato de independência do país o tornou célebre, mas não impediu que fosse sequestrado e morto, apesar de sua liberdade ter sido reivindicada pela União

\footnotetext{
247 "Congo: a maior guerra do mundo”. Adriana Carranca. Estadão. 20/10/2013 (Disponível em http://internacional.estadao.com.br/noticias/geral,congo-a-maior-guerra-do-mundo-imp-,1087710) (Último acesso em 27/05/2013).

248 “Entenda a história e a guerra da República Democrática do Congo”. BBC Brasil. 18/07/2003. (Disponível em http://www.bbc.com/portuguese/noticias/story/2003/07/030717_congomt.shtml) (Último acesso em 29/05/2016).
} 
Soviética perante o Conselho de Segurança da ONU, em dezembro de 1960. Seu corpo, soube-se depois, foi dissolvido em ácido por funcionários do serviço secreto da Bélgica, com apoio dos Estados Unidos da América ${ }^{249}$.

As crises apenas seguiram-se umas às outras. O país mergulhou em uma guerra sem fim, que terminou por torna-lo um dos países mais pobres e com maiores níveis de corrupção do mundo. Com o nome de Zaire, tornou-se uma base de operações contra Angola, então apoiada pela União Soviética. E nos anos 1990, sofreu invasão de Ruanda, que pretendia exterminar os rebeldes Hutus, responsáveis pelo celebre genocídio.

Novos grupos aproveitaram a ocasião e Mobutu foi deposto, com a ascensão de Laurent Kabila. Nas densas florestas do país - que novamente se tornaria a República Democrática do Congo - até mesmo Che Guevara e guerrilheiros cubanos fizeram seu esforço na empreitada de derrubar Mobutu, deixando evidente, assim, que a Guerra Fria era apenas um dos nomes da guerra de alta intensidade travada nas periferias do mundo ${ }^{250}$.

A "Primeira Guerra do Congo" foi marcada, portanto, principalmente pela queda de Mobutu e ascensão de Laurent Kabila, com apoio de Ruanda e Uganda. O conflito estava relacionado também à desestabilização no leste do país, como consequência do genocídio de Ruanda. Em represália à acolhida que Mobutu deu aos genocidas, as forças de Ruanda, sob presidência de Paul Kagame, tomaram Kinshasa e desta forma Kabila chegou ao poder.

Em agosto de 1998, eclodiu a chamada "Segunda Guerra do Congo”, como reação às tentativas de Kabila em expulsar os antigos aliados ugandeses e ruandeses. E nas décadas seguintes, além da disputa pelo poder na capital, diversos conflitos tornaram a situação ainda mais dramática, especialmente na região leste, onde chegaram a atuar pelo menos 70 diferentes grupos armados, a despeito da presença da missão da ONU. Dentre eles, os mais relevantes são a FDLR (Forças Democráticas para Libertação de Ruanda), as Foças Aliadas de

\footnotetext{
249 'President 'ordered murder' of Congo leader'. The Guardian. Martin Kettle. 10/08/2000. (Disponível em http://www.theguardian.com/world/2000/aug/10/martinkettle); “Opening the secret files on Lumumba's murder". Washington Post. Stephen Weissman. 21/07/2002; e "Belgium confronts its heart of darkness; unsavory colonial behavior in the Congo will be tackled by a new study”. The New York Times. Alan Riding. 21/09/2002. (Último acesso em 29/05/2016). 250 ANDERSON, Jon Lee. “Che Guevara, uma biografia”. Rio de Janeiro: Objetiva, 2005., pág. 553.
} 
Uganda (ADF) e o M23, que chegaram a tomar territórios do país para obtenção de recursos naturais ${ }^{251}$.

Um dos mais conhecidos, o M23, supostamente apoiado por Ruanda, formado principalmente por ex-integrantes do antigo grupo armado CNDP (Congresso para Defesa do Povo) -- então liderado por um dos mais conhecidos “Senhores da Guerra” da RDC, Laurent Nkunda, posteriormente preso e acusado por crimes de guerra, incluindo recrutamento de crianças, estupro em massa, assassinatos e pilhagens -- tomou parte do território de Goma, onde permaneceu de 2009 até 2013, até serem derrotados pelas forças da ONU ${ }^{252}$.

Em reação à crescente violência na região leste, pela primeira vez a ONU autorizou uma missão ofensiva, com liderança do general brasileiro Carlos Cruz, que tinha deixado o Haiti ${ }^{253}$. Outros grupos se seguiram ao M23, disputando poder e riquezas minerais, aproveitando-se do contexto de caos e ingovernabilidade na região leste do país.

O LRA (Lord's Resistance Army, em tradução livre, Exército de Resistência do Senhor), fundado no final dos anos 1980, em Uganda, por Joseph Kony -- misto de "Senhor de Guerra", líder religioso e místico, acusado formalmente por crimes de guerra e contra os direitos humanos pela Corte Internacional Criminal, pelo sequestro de dezenas de milhares de crianças, recrutadas forçadamente como soldados ou escravas sexuais - pretendia estabelecer um estado religioso, fundamentalismo cristão, baseado nos “dez mandamentos”, nos territórios do Congo e do Sudão ${ }^{254}$. O LRA é acusado, ainda, de orquestrar massacres em pelo menos quatro campos de refugiados.

Ao lado dos grupos mais organizados e estruturados, há ainda diversas milícias conhecidas como Mai-Mai ou May-May, que atuam principalmente em

251 Informações constantes do site “Global Conflict Tracker”. 26/05/2016. (Disponível em http://www.cfr.org/global/global-conflict-tracker/p32137\#!/conflict/violence-in-the-democraticrepublic-of-congo) (Último acesso em 29/05/2016).

252 “DRCongo: Who are the rebel groups at war?” France 24. 22/08/2012. (Disponível em http://www.france24.com/en/20120822-democratic-republic-congo-various-rebel-groups-warrwanda-uganda) (Último acesso em 29/05/2016).

253 “General brasileiro diz que ONU mudou meta militar no Congo”. BBC Brasil. Luis Kawaguti. $11 / 02 / 2014$ (Disponível

em http://www.bbc.com/portuguese/noticias/2014/02/140210_general_congo_fdlr_lk) (Último acesso em 29/05/2016).

254 “A Lords Resistance Army commander goes on trial but Joseph Kony still eludes justice”. Time. Aislinn Laing. 21/01/2016. (Disponível em http://time.com/4186861//ra-kony-ongwen/) (Último acesso em 29/05/2016). 
Kivu Norte e Kivu Sul, disputando territórios, mas também pilhando aldeias, roubando e cometendo crimes graves, como matança indiscriminada, estupros e recrutamento forçado de crianças, motivados, principalmente, por razões étnicas. Dentre muitos destes grupos, os mais conhecidos são o Mai-Mai Sheka, Mai-Mai Kifuafua, Mai-Mai Simba e Mai-Mai Yakutumba.

Os soldados Mai-Mai são temidos por seus adversários porque supostamente são invulneráveis a tiros, em razão de um "líquido mágico” que usam sobre seus corpos. Sheka, líder do Mai-Mai Sheka, que tinha Walikale como território de atuação, tem contra si mandados de prisão por crimes contra humanidade e conseguiu manter-se impune graças à ajuda de soldados das forças armadas, com quem mantém relações ${ }^{255}$.

Por fim, grande parte da terrível violência sofrida pelo povo congolês é praticada pelo exército do próprio país. Um relatório do escritório da "United Nations Joint Human Rights Office” contabiliza pelo menos 135 casos de violência sexual perpetrada por membros das forças armadas apenas na cidade de Minova, durante o mês de novembro de 2012, no auge do conflito entre o exército e o grupo M23. Outros crimes, incluindo pilhagens, roubos e agressões são atribuídos a membros das forças armadas ${ }^{256}$.

No final de 2014, o Coronel Bedi Enganela, conhecido como "Coronel 106”, foi sentenciado à prisão perpétua por crimes contra a humanidade, além de ter sido condenado por ter mantido mulheres como escravas sexuais. Quase na mesma época, o general Jerome Kakwavu, outro oficial de alta patente das forças armadas, foi condenado a 10 anos por estupro, assassinato e tortura. Em outro julgamento, 25 soldados que atuavam em Kivu Norte e na Província Oriental foram condenados por estupro de mulheres e garotas que deveriam ter protegido $^{257}$. A impunidade, no entanto, não é apenas comum, mas tornou inclusive uma forma de gerir os conflitos: muitos membros de grupos rebeldes são

\footnotetext{
255 "DR Congo: Wanted rebel's troops instill fear". Human Rights Watch. 06/01/2015. (Disponível em https://www.hrw.org/news/2015/01/06/dr-congo-wanted-rebels-troops-instill-fear) (Último acesso em 29/05/2016).

256 "UNJHRO report on human rights violations by FARDC and M23 in Goma, Sake and around Minova. 15 nov - 2 dec 2012”. Reliefweb. 08/05/2013. (Disponível em http://reliefweb.int/report/democratic-republic-congo/un-denounces-sexual-violence-other-seriousviolations-eastern-drc) (Último acesso em 29/05/2016).

257 "UN envoys welcome conviction of Congolese army officer for crimes against humanity". UN News Service. 16/12/2014. (Disponível em http://www.refworld.org/docid/549404ba4.html) (Último acesso em 29/05/2016).
} 
anistiados e integrados às forças armadas como condição para entregar as $\operatorname{armas}^{258}$.

\section{5}

\section{Modulações da guerra}

Além das mortes causadas diretamente pelas guerras e conflitos entre diferentes grupos, as doenças e a má nutrição foram responsáveis pela morte de mais de mil pessoas por dia naquele país, segundo relato da "International Rescue Committee”, uma agência humanitária com sede em Nova Iorque ${ }^{259}$. E há um incalculável número de pessoas submetidas a trabalhos forçados ou degradantes, principalmente nas minas do país.

A respeito da relação entre guerra e os minérios, a Anistia Internacional publicou relatório revelando que as mais importantes empresas de produtos eletrônicos e de informática - Apple, Samsung e Sony, dentre outras, cujo lucro global gira em cerca de US\$ 125 bilhões -- “falharam em identificar” o uso de trabalho infantil nos minerais usados em seus aparelhos.

Crianças de sete anos de idade foram encontradas trabalhando em minas de cobalto, sob condições extremamente perigosas. Nas minas do Congo - país responsável por mais de cinquenta por cento do cobalto produzido no mundo morreram pelo menos 80 pessoas entre setembro de 2014 e dezembro de 2015 . Também foi revelado que empresas chinesas subsidiárias de uma grande empresa mineradora chinesa -- Zhejiang Huayou Cobalt - estão envolvidas como intermediárias no comércio do cobalto. A Anistia relata casos de garotos órfãos, com idade de 12 anos, trabalhando 24 horas nos túneis ${ }^{260}$. De acordo com a UNICEF estima-se que 40 mil crianças estejam nestas condições no Congo ${ }^{261}$.

258 “Congo, Democratic Republic of (Kinshasa)”. Freedom House. 2015 (Disponível em https://freedomhouse.org/report/freedom-world/2015/congo-democratic-republic-kinshasa) (Último acesso em 29/05/2016).

259 "1,000 a day dying in Congo, agency says”. CBCNews Wordl. 10/12/2004. (Disponível em http://www.cbc.ca/news/world/1-000-a-day-dying-in-congo-agency-says-1.475042) (Último acesso em 29/05/2016).

${ }^{260}$ Sobre o tema, há o documentário "Les Enfants du diable”, de Daniel Grandclément (disponível em https://www.youtube.com/watch?v=x6qaBGkbya0) (Último acesso em 31/05/2016).

261 "Relatório acusa Apple, Samsung e Sony de conivência com trabalho infantil". BBC Brasil. 19/01/2016. 


\section{6}

\section{Operação "Likofi" e o massacre de crianças}

Quanto às crianças, elas mereceriam atenção especial em qualquer narrativa sobre a imensa guerra no Congo, tal a variedade de brutalidades de que são vítimas. Desde crianças recrutadas como soldados a garotas sexualmente escravizadas, passando por trabalho em minas e uma série de outras violências. Uma das mais emblemáticas desta guerra é a operação policial que o governo congolês desencadeou contra crianças de rua, sob o pretexto de diminuir a criminalidade urbana, atribuída sobretudo às gangues de jovens, os chamados "kulunas”.

A operação policial contra as crianças e jovens permite-nos ver como a guerra fragilizou ou erodiu completamente as instituições de amparo e de justiça, e, ao mesmo tempo, como ela se manifesta em diferentes modulações, ora na expressão mais tradicional do que se entende por guerra, em sua alta intensidade soldados, infantarias e comandos -- e também em sua expressão cotidiana, de baixa intensidade, atravessando as relações sociais como um todo, na forma do extermínio de crianças e de estupro contra as meninas.

Somente em 2014, cerca de cem garotos apontados como "kulunas” foram “desaparecidos” das ruas, enquanto algumas dezenas fugiram da República Democrática do Congo, temendo por suas vidas ${ }^{262}$. Desaparecimentos e motes dos adolescentes coincidem com o começo da operação "Likofi” (em tradução livre, seria algo como "punho” ou “soco”), implementada pelo presidente Joseph Kabila, em cumprimento à sua promessa, feita durante as campanhas, de acabar com a criminalidade das gangues ${ }^{263}$. A operação durou alguns meses, entre o fim

(Disponível em http://www.bbc.com/portuguese/noticias/2016/01/160119_trabalhoinfantil_anistia_rp?ocid=socialf low_facebook\%3FSThisFB). (Último acesso em 20/01/2016).

262 Os vídeos $\quad$ estão $\quad$ disponíveis nas https://www.youtube.com/watch?v=YmEwxgmzbcQ) e são úteis para ilustrar a violência brutal cometida contra crianças e adolescentes dentro do contexto da operação "Likofi”.

263 Human Rights Watch, Operation Likofi: Police Killings and Enforced Disappearances in Kinshasa, Democratic Republic of Congo , 21 November 2014, ISBN: 978-1-6231-32040 , available at: http://www.refworld.org/docid/546f3b064.html [Acessado dia 03/02/ 2015]. 
de 2013 até março de $2014^{264}$, e foi pensada como um plano para "erradicar" problemas de segurança urbana $^{265}$.

Na internet, circulam alguns vídeos sobre a violência contra os kulunas. Em um deles, dois garotos andam pelas ruas, ladeados por policiais militares e cercados por uma multidão. Eles estão com os braços amarrados nas costas e carregam cartazes feitos de papelão, com escritos quase ilegíveis. Estão muito machucados, com o rosto sangrando, ferimentos na cabeça e o corpo marcado por golpes. Assustados com os gritos da multidão e com os policiais que os observam, falam entre soluços. Na multidão, há homens, mulheres e crianças, muitas delas aparentemente se divertindo com o espetáculo. Não é possível entender o que dizem, mas é evidente o que acontece.

Eles foram eleitos para um espetáculo de violência. Em uma das placas improvisadas sob o pescoço de um dos jovens, é possível ler "kuluna”. Em outro vídeo, o corpo de um garoto é visto dentro de um poço. Há muitas marcas de violência, como um grande corte no ombro. E grandes pedras sobre o corpo. De costas, é possível ver que ele tentava proteger o rosto e a cabeça. Novamente, há uma turba em volta e muitos sorriem. Crianças brincam em volta. Enquanto falam aos gritos diante da câmera, alguns homens mostram expressões severas. O garoto é apontado como um "kuluna” e foi morto por populares.

Os jovens "kulunas” foram apontados como responsáveis por um surto de roubos e outros crimes na capital do país desde 2006 e foram também recrutados por políticos durante as eleições para intimidar seus adversários ${ }^{266}$. Em apenas dez dias de operação, ao menos vinte pessoas, entre as quais 12 crianças, foram mortas de maneira arbitrária por agentes do governo ${ }^{267}$. Em março de 2014, de acordo com organizações internacionais protetoras de Direitos Humanos, o

264 OCHA: "UNICEF and MONUSCO are concerned by reports on the disappearance and assassination of youth and children in Kinshasa". 27 de Novembro de 2013. Disponível em: "http://reliefweb.int/report/democratic-republic-congo/unicef-and-monusco-are-concerned-reportsdisappearance-and [Acessado dia 25/06/2014].

${ }^{265}$ France: Office français de protection des réfugiés et apatrides, Rapport de mission en République démocratique du Congo (RDC), Abril 2014, Disponível em: http://www.refworld.org/docid/537ef09a4.html [Acessado dia 26/06/2014].

${ }^{266}$ Ibid referência.

${ }^{267}$ Ibid referência. 
número de desaparecidos superava uma centena de jovens ${ }^{268}$. Os relatos incluem execuções sumárias e extrajudiciais feitas em áreas públicas ${ }^{269}$.

Para garantir sua impunidade, policiais envolvidos nas mortes e desparecimentos passaram a intimidar e ameaçar familiares e amigos das vítimas, assim como testemunhas. Chegaram a impedir que familiares reclamassem pelos corpos ou que realizassem o funeral Jornalistas e médicos também eram ameaçados para não relatarem informações sobre a operação, sob o argumento de tratar-se de “assunto confidencial do governo" ${ }^{270}$. O mesmo padrão de arbitrariedade e violência que se vê em outros contextos e países, para comprovar que a guerra é mesmo uma condição geral e global deste tempo.

Em novembro de 2013, uma operação executada pelo general Kanyama, comandante da Polícia Nacional do Congo, do distrito de Lukunga, prendeu em Brazzaville, capital da República do Congo, 45 supostos membros de "kulunas" que haviam fugido ao país buscando refúgio. Há registros de que outros membros de "kulunas" que tentaram fugir da capital para demais regiões da RDC também foram interceptados e presos ${ }^{271}$. Algumas pessoas também testemunharam o abuso policial direcionada às famílias dos suspeitos: os policiais entravam em suas casas e, além de intimida-las, saqueavam a casa, levando joias, celulares e outros itens de valor. Quando o suspeito procurado não se encontrava em casa, os policias às vezes levavam outras pessoas em seu lugar ${ }^{272}$.

A UNICEF e a MONUSCO requisitaram às autoridades congolesas que realizassem investigações e, caso fosse necessário, que punissem os responsáveis. Ambas as organizações emitiram nota no sentido de que se garantissem, em quaisquer condições, a defesa dos direitos humanos e a proteção especial das crianças, como consta em suas leis internas e nos tratados e convenções internacionais dos quais o país é signatário.

Em novembro de 2013, a Organizações das Nações Unidas requisitou às autoridades congolesas medidas imediatas quanto à apuração, investigação e punição dos responsáveis. A ONU se prontificou a auxiliar o país na busca por

\footnotetext{
${ }^{268}$ BBC NEWS, Maud Julien. "DR Congo police accused of brutality against Kinshasa gangs". 18 de março de 2014. Disponível em: http://www.bbc.com/news/world-africa-26638525 [Acessado dia 25/06/2014]

269 Ibid.

${ }^{270}$ Ibid referência.

${ }^{271}$ Ibid referência.

${ }^{272}$ Ibid referência.
} 
soluções concretas e duráveis para a situação da sua juventude ${ }^{273}$. Na mesma linha, no dia 30 de Novembro de 2013, o RENADHOC, a "Rede Nacional de Organizações de Direitos Humanos da República Democrática do Congo”, denunciou e condenou os métodos implementados pelas autoridades do país no âmbito da operação "Likofi”"274.

O chefe da força de polícia congolesa, Charles Bisengimana, afirmou em entrevista à emissora BBC, que foram cometidos “abusos” durante a realização da operação, contudo, negou os assassinatos, afirmando, por fim, que os responsáveis pelos “excessos” foram levados à justiça. Acrescentou ainda que alguns dos membros da polícia declarados culpados foram sentenciados a prisão perpétua, ou mesmo à pena de morte. Contudo, magistrados entrevistados afirmaram que nenhum policial envolvido nos abusos foi preso ou condenado por assassinatos ou desaparecimentos $^{275}$.

De acordo com reportagem da Radio Okapi, a Radio das Nações Unidas na RDC, no dia 11 de dezembro de 2013, o Ministro do Interior, Richard Muyej Mangez, compareceu à Assembleia Nacional congolesa para responder às alegações das execuções dos jovens vinculados às “kulunas” durante a operação "Likofi”. O Ministro reconheceu que houve abusos por parte dos policiais, mas alegou que algumas das mortes foram atos de legitima defesa. Na audiência, o ministro afirmou ainda que a primeira das operações "Likofi” aprisionou 669 “kulunas” até o dia da audiência ${ }^{276}$.

Segundo relatório do Departamento de Estado dos Estados Unidos, destas 669 pessoas detidas, 349 foram enviadas para penas de prisão perpétua, 28 eram menores de idade, 23 foram enviados a tribunais da juventude e cinco foram liberados. Cinco policiais envolvidos foram presos. No entanto, não há informações disponíveis quanto à natureza das acusações ou sobre o processo de

273 CONSELHO DE SEGURANÇA DA ONU, Report of the Secretary-General on the United Nations Organization Stabilization Mission in the Democratic Republic of the Congo , 17 December 2013, S/2013/757, Disponível em: http://www.refworld.org/docid/52d3afbf4.html [Acessado dia 25/06/2014].

274 RENADHOC: "Déclaration du RENADHOC au sujet de la traque des « kuluna » dans la ville de Kinshasa en République Démocratique du Congo" 30 de Novembro de 2013. http://www.renadhoc.org/?p=613 [Acessado em 26/06/2014]

${ }^{275}$ Ibid referência.

276 RADIO KAPI. “Opération «Likofi» : le ministre de l’Intérieur s’explique sur les allégations d'exécutions” 12 de Dezembro de 2013. Disponível em: radiookapi.net/actualite/2013/12/12/operation-likofi-le-ministre-de-linterieur-sexplique-sur-lesallegations-dexecutions/\#.U6r_vpRdW-1 [Acessado dia 25/06/2014] 
investigação e de julgamento do caso $^{277}$. Entre novembro e dezembro de 2013, houve um aumento de $121,7 \%$ da demanda por abrigos por parte de crianças de rua, no exato período da implementação da operação Likofi ${ }^{278}$. Crianças de rua fugiram temendo serem confundidas com membros das "kulunas"279.

277 United States Department of State, 2013 Country Reports on Human Rights Practices Democratic Republic of the Congo, 27 February 2014, Disponível: http://www.refworld.org/docid/53284b3514.html [Acessado dia 26/06/2014].

${ }^{278}$ UNICEF. “ Monthly Humanitarian Situation Report - 24th of November 2013-02 January 2014 in Democratic Republic of the Congo" . Disponível em http://www.protectingeducation.org/sites/default/files/documents/unicef_drc_sitrep_24nov2013_2j an2014.pdf [Acessado dia 26/06/2014].

${ }^{279}$ RADIO OKAPI. “4 5 Kulunas arrêtés à Brazzaville renvoyés à Kinshasa” 28 de novembro de 2013. Disponível em: http://radiookapi.net/actualite/2013/11/28/45-kulunas-arretes-brazzavillerenvoyes-kinshasa/\#.U6xh5pRdW-0 [Acessado dia 26/06/2014]. 


\section{9}

\section{Dimensão afirmativa da crise}

"Prospero: We cannot miss Caliban. He does make our fire, fetch in our wood, and serves in office.

That profit us".

The Tempest.

Shakespeare.

"Eles não sabem fazer nada, mas tudo sabem fazer".

Jean Rouche $e^{280}$

O monstro Caliban não pode ser simplesmente morto ou banido. Seu trabalho é necessário e por isso ele é mantido cativo dentro da ilha. O selvagem Caliban, personagem de "Tempestade”, de Shakespeare, é a figura emblemática da ameaça representada pelo nativo colonizado. $\mathrm{O}$ anagrama para Canibal, como observam Hardt e Negri (2009, p. 97). Mas Caliban pode também ser retomado como símbolo da resistência nas lutas anticoloniais travadas no Caribe durante o século XX.

Se do ponto de vista dos colonizadores, o monstro está aprisionado entre a razão e loucura, progresso e barbárie ou modernismo e anti-modernismo, da perspectiva do colonizado, em sua luta por libertação, não há dualismos, nem dialéticas. Caliban, com mais razão e civilização que os colonizadores, é monstruoso na medida em que seu desejo por libertação excede as relações coloniais.

Prospero não pode viver sem Caliban, assim como o capital não vive sem a força dos trabalhadores. A história da modernidade -- e, portanto, também a história da república - é marcada por este imenso escândalo que é a escravidão. E a despeito de todos os esforços para apagar a escravidão da história da

\footnotetext{
${ }^{280}$ Assim o documentarista Jean Rouche descreveu um grupo de jovens nigerianos, em 1958, que
} migravam para a Costa do Marfim em busca de emprego. 
modernidade ou para recolocá-la como o momento negativo e indesejado do capitalismo, a verdade é que a violência da escravidão foi e ainda é o componente essencial dos mecanismos de exploração capitalista.

A ambivalência da modernidade, entretanto, contém o elemento da resistência, do êxodo e das lutas por libertação. É a outra dimensão da modernidade e da civilização. É por isso que a modernidade será sempre duas modernidades. E se a noção de conquista enfatiza a violência e brutalidade da expansão colonialista, isso não significa considerar os colonizados como passivos.

O esforço por reconhecer a relação entre escravidão e a república moderna, revela, de outro lado, a ambivalência da modernidade, constituída, de um lado, pela exploração violenta pela escravidão e, de outro, pela resistência dos escravos. Não como figura abstrata, sempre imagem da subjugação, mas como sujeito que só pode ser tornar escravo porque é livre.

Se os escravos estivessem sempre sob absoluta dominação, não haveria poder a exercer sobre eles, pois somente sobre os homens livres pode haver poder e tentativa de dominação. Ninguém é capaz de transferir completamente para outro todos os seus direitos e seu poder, sem abandonar sua condição de humano, nem haverá soberano que poderá fazer tudo o que deseja, dizia, em outras palavras, Baruch Spinoza ${ }^{281}$.

A escravidão, como mostra a história da Revolução Haitiana -- a despeito de todos os esforços por apaga-la da história das revoluções e, principalmente, por negar-lhe a qualidade de primeira revolução republicana da era moderna -- foi vencida não pela consciência dos valores republicanos, nem tampouco pela evolução progressiva do capital, como se tratasse de um resquício pré-moderno e pré-capitalista. Em vez disso, a escravidão foi destruída pela resistência dos próprios escravos.

É a história dos escravos que protagonizaram sua emancipação nos Estados Unidos da América -- como lembram Hardt e Negri (2009, p. 76), citando W.E.B. Du Bois ${ }^{282}$-- jogando luz sobre a incongruência entre escravidão e democracia, e tornando possível uma democracia que inclui as pessoas de todas as cores. A resistência dos escravos pode ser considerada anti-moderna não porque se opõe

\footnotetext{
${ }^{281}$ Spinoza, Baruch. Tratado Teológico Político, São Paulo: Perspectiva, 2014, p. 296.

${ }^{282}$ HARDT \& NEGRI, 2009, pág. 76, citando W.E.Du Bois. Black Reconstruction. New York, Russel \& Russel, 1935 e The Gift of Black Folk. New York. AMS Press, 1971.
} 
aos valores ideológicos de liberdade e igualdade, mas justamente porque desafia as relações hierárquicas de poder no centro da modernidade, constituindo, pelas lutas, os valores mais importantes da modernidade.

\section{1}

\section{Pós-modernidade, êxodo e subtração}

A modernidade não foi apenas abatida por crises, mas instituída desde sua origem como uma crise. E sempre, desde sua gênese, como negatividade e afirmação. De um lado, a escravidão, o colonialismo e a expropriação, de outro, as lutas por independência, liberdade e autonomia. Os desafios para a liberdade e democracia no mundo pós-moderno ou da soberania do biopoder são diferentes do que eram antes. E hoje a guerra global e generalizada, a vampirização das subjetividades e o enclausuramento são o terreno onde se dão as lutas. E as lutas, dentre suas várias possibilidades, se dão especialmente pelo êxodo, isto é, pela subtração do corpo em relação à opressão, pelo esvaziamento do biopoder.

Se a modernidade era constituída principalmente pelo terror da escravidão, a pós-modernidade do biopoder e do "biocapitalismo” (Negri, 2015) apresenta aos indivíduos outras formas de enclausuramento. Contudo, outras formas de resistir foram criadas e mesmo Caliban, o monstro, ganha outro aspecto.

De certo ponto de vista, o monstro pode ser associado à ideia da ameaça externa, da desordem, do caos e da violência. Ou ainda, de um corpo disforme, assimétrico, distante dos padrões normais de estética ou comportamento. O Caliban é temido e escravizado pelas mesmas razões: por sua desmedida. Monstro também é o corpo sem estrutura definida e que não tem funções orgânicas determinadas. Anterior à formação das classes sociais, dos corpos institucionais, como diz Barbara Szaniecki ${ }^{283}$. Anterior à “multidão”, nos termos do conceito desenvolvido por Hardt e Negri (2005). O monstro, no entanto, não é anterior a nada e sua presença é constante, sempre à espreita, como diz Szaniecki. Nem bom, nem mau, nem verdadeiro, nem falso, o monstro é o terreno da produção

${ }^{283}$ SZANIECKI Barbara. "Monstro e multidão: a estética das manifestações”. Entrevista Instituto Humanitas Unisinos. 15/07/2013. (Disponível em http://www.ihu.unisinos.br/entrevistas/521910monstro-e-multidao-a-estetica-das-manifestacoes-entrevista-especial-com-barbara-szaniecki)

(Último acesso em 04/07/2016) 
biopolítica de democracia e dos sujeitos. A possibilidade de abertura em meio ao caos e à crise da pós-modernidade.

Talvez seja justamente esta desmedida tão ameaçadora que traga em si a crise como criação. No terreno do biocapitalismo, a despeito de todas as formas de expropriação, opressão e enclausuramento, a desmedida é possível, inclusive e sobretudo pela forma da subtração e do êxodo. E se o poder investe diretamente sobre o corpo, é pelo corpo, mesmo o corpo mais fraco e ferido, que se farão as fugas.

No mundo pós-moderno da soberania do biopoder, a fuga pode surgir como possibilidade de democracia. Ou a emergência da democracia pode assumir a forma de uma subtração. Como dizem Hardt e Negri (2005, p. 35), na forma da fuga e do êxodo da soberania. E a despeito do que parece, o êxodo nunca será pacífico ou conciliatório, mas implica mesmo uma resistência ativa, um combate de guerrilha contra as forças do biopoder. Uma maneira de esvaziar o poder do inimigo e de construção de uma nova sociedade por parte dos sujeitos que fogem.

Apesar de todo o poder e de todo o arsenal disponível, o capital não é um monarca; é uma relação (Negri, 2015, p. 62). Se não houvesse o trabalho vivo -inclusive o trabalho feito pelos migrantes e inclusive o trabalho implicado na fuga e na constituição de autonomia - o capital sequer existiria. Como diz Sandro Mezzadra, “não há capitalismo sem migração” (2005, p. 144). E poderíamos dizer, sem mobilidade. O capitalismo, a propósito, transformou a liberdade e a mobilidade em competitividade (Ibidem).

Frente a toda exploração e a toda opressão sempre há formas de resistência. A liberdade da fuga não é menos liberdade porque se dá em situações miseráveis e desesperadas; ao contrário, é justamente isso que a faz mais livre (Negri \& Cocco, 2005). É preciso insistir, ainda, que a fuga sempre é primeira; e que o enclausuramento dos sujeitos é um projeto do poder, seja para evitar a mobilidade dos trabalhadores em busca de melhores condições, seja para impedir que os sujeitos fugissem das várias formas de exploração. 


\section{2 \\ Insubmissão, desutopia e libertação}

A crise é o modo que se convencionou dar à recomposição reativa do biopoder, ou seja, a tentativa de domesticar a potência que a fuga possui de desestabilizar as hierarquias de poder, as identidades e os pontos fixos das relações de dominação. Neste sentido, ela é apenas negatividade e medo; confirmação de toda dor e, mais grave, anuncia a impotência frente à dor.

Contudo, a crise é também criação e positividade. Neste sentido, a crise é a fuga em si mesma, a criação que se realiza na desestabilização e a produção de novas subjetividades. Uma crise que se faz não sem dor, mas ainda assim se faz como afirmação e produção de vida. E que tem a liberdade dos sujeitos - ou sua luta por libertação - como projeto, mas também como motor.

Somente porque são livres os refugiados e sujeitos que fogem, e justamente porque lutam por sua libertação, é que a crise pretende se impor contra eles com o nome de escassez. As relações de poder e dominação, de um lado, e a insubmissão da liberdade, de outro, não estão nunca separadas. Somente sobre sujeitos livres e enquanto livres se pode exercer o poder, entendido como forma de governo ou governabilidade. A liberdade aparece sempre como condição de existência do poder, ao mesmo tempo em que as lutas e a resistência surgem como antecedente a ele, não exatamente no sentido do tempo, mas no sentido da produção e da constituição do ser.

Por isso dizemos que há uma crise que é determinada pelos sujeitos em fuga e por isso dizemos que esta crise é não apenas afirmação dos sujeitos, mas é constituinte, porque é no desenrolar da crise que eles se constituem, na produção de sua liberdade - ou melhor, libertação - e na sua própria produção como sujeitos. A crise diz respeito a uma ontologia. E quanto a isso, à produção dos sujeitos em sua luta, dizemos que se trata de uma produção que conjura qualquer comiseração, qualquer negatividade e, sobretudo, qualquer utopia.

Assumimos, no entanto, aquilo que mais nos interessa: a crise em sua dimensão positiva e constituinte, isto é, a crise em seu sentido mais profundo e em sua potência criativa. Eis a crise como uma crise determinada pelos sujeitos em fuga, conduzida pelo esvaziamento que as diásporas, os êxodos e as fugas provocam, ao mesmo tempo em que fecundam novas comunidades e territórios. A 
crise é uma abertura determinada pelos sujeitos em fuga, graças à produção subjetiva que a fuga, prenhe pelo desejo e pela afirmação, é capaz de criar.

Insistiremos, assim, que a fuga, movimento simultaneamente negativo e positivo, como recusa e afirmação, deve ser considerada em sua força extraordinária de criar vida, em sua capacidade de produzir excedentes. Pois, como forma de resistência contra a opressão, tirania e exploração, é a brecha para a ampliação da própria vida. Em vez de escassez e exceção, produção de maisvida. E, por isso, a fuga é resistência e criação. Há uma crise, portanto, que é pura afirmação; uma crise de excedente de vida.

E do que é então feita esta resistência que constitui a fuga dos refugiados? Se não uma reação, como a resistência pode determinar uma crise constituinte? Em primeiro lugar, é preciso ver que em toda relação de poder - inclusive as relações que determinaram o "deslocamento forçado" ou que fecharam as fronteiras - há resistência. No cerne nas relações de poder e como condição de sua existência, há uma insubmissão que persiste e, portanto, não existe relação de poder sem escapatória ou sem reviravolta eventual (Foucault, 2014, pág. 138).

Toda relação de poder implica, ao menos virtualmente, uma estratégia de luta, desde que não se trate de uma luta de morte, em que um dos lados seja totalmente massacrado ou inviabilizado. Para cada relação de poder, a estratégia de luta constitui uma fronteira, em que a indução calculada das condutas entre os outros não pode mais ir além da réplica à sua própria ação (Foucault, 2014, pág.139). Entre relação de poder e estratégia de luta há sempre encadeamento e inversão, um jogo constante de enfrentamento. Quase nunca se trata de uma luta simétrica, pois a situação de poder não é sempre a mesma e a relação entre poder e luta é sempre em termos desiguais.

É correto porém dizer que há inversões e que se trata de um jogo dinâmico, em que ora um leva vantagem sobre o outro, determinando-se reciprocamente em suas condutas, mas sem que isso seja uma dialética. Sempre é possível mudar a situação. Se não houvesse resistência, nem sequer haveria relações de poder, porque tudo se resumiria a uma questão de pura dominação. Da mesma forma que não se pode tomar o poder sempre como um negativo, em termos de repressão e fechamento, a resistência não quer dizer simplesmente algo reativo, um dizer não.

Ela é também um processo de criação. A resistência, na verdade, vem em primeiro lugar, é anterior ao poder que ela enfrenta; é coextensiva a ele e 
absolutamente contemporânea (Foucault, 2004, pág. 241); está superior a todas as forças do processo, na medida em que ela obriga, sob seu efeito, as relações de poder a mudar (Foucault, 2014, pág. 257). Dizer não constitui a forma mais simples e mínima de resistência, ainda que, em certos momentos, seja o necessário ou o possível. Quanto a isso, não há um lugar fora desta relação, não há lugar fora das relações de poder.

Por isso, em relação aos refugiados e aos que fogem, é a fuga em si mesma, seja nomeada como deslocamento voluntário ou não, e justamente pelo desejo que a constitui, que se torna objeto dos dispositivos de controle: fugir é o pecado que cometem. Insubordinaram-se contra a violência em seu país e contra as barreiras que os queriam retidos num determinado território ou numa determinada identidade. O poder não é capaz de impedir completamente os deslocamentos, êxodos e diásporas, mas investe-se de forma a desativar o potencial subversivo que faz parte da fuga. Ou seja, os efeitos de poder dizem respeito a uma prática de docilização dos sujeitos que pretenderam subverter a lógica das fronteiras. Lógica essa que se remete a conjunto de normas, saberes e poderes que governam os dispositivos de segurança, os territórios e as populações.

A fuga dos refugiados e migrantes denuncia um mundo todo em colapso, uma guerra generalizada e descentralizada, de diferentes intensidades - ocupação militar "pacífica” e repressão de manifestantes com armas "não letais”, de um lado, bombardeio com armas químicas, de outro - indicam também a crise convulsiva do estado-nação e das tradicionais formas de exploração e opressão. Tais deslocamentos, movidos não pela falta, mas pelo desejo e pela afirmação da vida - ainda que deixando para trás a mais brutal violência - são capazes de criar novas comunidades, novas formas de relação, novos sentidos, novas terras imaginadas e, enfim, novos sujeitos.

Na relação entre poder e resistência, há uma diferença de qualidade entre as forças ativas e as forças reativas. Enquanto as forças reativas incidem sobre a realidade como ela é, constituídas em um movimento secundário de adaptação ou de negação, as primeiras são forças plásticas que procuram constituir uma realidade, determinando, sobretudo, a diferença de um novo lugar (Pacheco et al, 2002). As forças reativas não possuem potência afirmativa e portanto não podem ser duplicadas ou dobradas, enquanto que as forças ativas, mesmo quando contidas em um movimento aparentemente de retirada - como é a fuga - são 
capazes de criar excedência de ser e de vida. Esta é a capacidade constituinte da resistência.

Mesmo diante das fronteiras, dos mares e abismos, ou mesmo frente a uma imensa rede de poder que também nomadizou, as formas de resistência continuam atuando, sempre produzindo excedentes, em termos de uma vida mais ampla, de uma vida coletiva com mais conexões e cooperação e com inteligência. Toda fronteira é também o conjunto de outras vozes e narrativas dissonantes, irrupções dissidentes, enunciadas por mulheres, pelos loucos, pelos colonizados, pelos traços e grupos minoritários, incluindo aqueles que portam sexualidades e comportamentos constantemente policiados. Por tudo isso, Homi Bhabha diz que a “demografia do novo internacionalismo é a história da migração pós-colonial, as narrativas da diáspora cultural e política, os grandes deslocamentos sociais de comunidades camponesas e aborígenes, as poéticas do exílio, a prosa austera dos refugiados políticos e econômicos” (apud Pelbart, 2003, p.124).

\section{3}

\section{Exceção como potência: a vida como excedente}

Seguir os passos de Fassin e Agamben sobre o campo como exceção, no entanto, nos faria fechar os olhos para duas coisas importantes: a primeira, que o governo do biopoder faz operar a exceção como regra e, neste sentido, a existência destes espaços - os campos - não confirmam a ausência, mas, ao contrário, a presença da regra, da lei e do estado. Em segundo lugar, nos impediria de ver que estes espaços funcionam sim como exceção, mas a exceção afirmativa das lutas, as mesmas que constituem novos espaços de vida. Sangatte, Calais e os outros campos são também os espaços de fuga e espaços onde resistência é forjada.

Diagnosticar a exceção não pode implicar na negação de suas ambivalências, ou seja, do seu caráter ao mesmo tempo trágico e também afirmativo. Temos estes planos sobre os quais experimentar uma nova afirmação da vida, a partir mesmo da exceção, mas agora em sua dimensão afirmativa ou positiva. A vida nua não pode ser referida sempre à pura e absoluta impotência. E esta é a primeira e principal crítica que se faz à teoria da exceção desenvolvida por Agamben. Não se trata de negar o drama de que são vítimas os refugiados ou a 
tragédia que determina sua fuga. Nem é possível fechar os olhos para a violência que se abate sobre os imigrantes as minorias do mundo. Mas é preciso ir além e verificar que mesmo naquilo que parece o último sopro de vida ainda há resistência.

Uma das fortes objeções que são feitas ao uso do conceito de vida nua, como Agamben a formulou e como se a utiliza, é que a vida em si, isto é, o simples fato de viver já é, em si, e por si, a afirmação vital e política. Antes de tudo, a vida, como tal, nunca é nua. Essa vida que parece nua e animal só é nua em aparência, mesmo aquela dos muçulmanos, pois ela é sempre “composição de relações, amizades intensas, vida vivida, natureza naturante, força produtora de formas de vida, de estratégias, de avaliações” (Pelbart, 2003). Até o silêncio, nos diz Pelbart, ou também a recusa de se falar ou de se alimentar - como o jejuador de Kafka ${ }^{284}$ - pode ser expressão de uma riqueza de relações.

Nomeada como vida nua pelo poder, porque desprovida da qualidade que a protegeria, a vida mesmo não faz escolha, se não resistir, se não pensar em si mesma para além das determinações, do julgamento e da autoridade. A vida nua, portanto, não se submete a uma soberania que lhe é exterior, para então afirmar a sua própria (Pelbart, 2003, pág. 66). O pensamento de Agamben sobre a exceção supõe, portanto, uma zona de indistinção que se produz entre humanidade e animalidade e que ele descreve como uma vida meramente biológica.

Essa vida é, segundo ele, resultado do próprio processo de hominização e é o único lugar onde pode se constituir uma resistência ao poder. Ocorre, no entanto, que sua ideia de resistência se aproxima demasiadamente da ideia de negação ou profanação da própria vida. A resistência termina, por fim, em pura impotência, e em vez de uma resistência biopolítica, mostra-se como "tanatopolítica”.

Quanto ao conceito de vida nua, é preciso ver ainda que Agamben supõe uma separação irreal entre homem e natureza, como se a natureza existisse apartada da cultura e a cultura como uma diferença radical da natureza, por vezes, como um algo a mais, uma evolução resultante do trabalho humano (hominização) em relação à natureza estável e sempre originária. Essa separação ignora, entretanto, que a vida, não só do homem, mas de todos os seres, nunca existiu se

${ }^{284}$ Referência a conto de F. Kafka, “O artista da fome”, de 1922. 
não em uma cultura, ou melhor, em várias e diversas culturas. Denunciar a exceção não pode implicar na negação de suas ambivalências, ou seja, do seu caráter ao mesmo tempo trágico e também afirmativo.

Temos estes planos sobre os quais experimentar uma nova afirmação da vida, a partir mesmo da exceção, mas agora em sua dimensão afirmativa ou positiva. A vida nua não pode ser referida sempre à pura e absoluta impotência. E esta é a primeira e principal crítica que se faz à teoria da exceção desenvolvida por Agamben. Não se trata de negar o drama de que são vítimas os refugiados ou a tragédia que determina sua fuga. Nem é possível fechar os olhos para a violência que se abate sobre os imigrantes as minorias do mundo. Mas é preciso ir além e verificar que mesmo naquilo que parece o último sopro de vida ainda há resistência.

O “muçulmano”, a figura cinzenta que habita o campo de concentração e do qual todos os demais prisioneiros guardavam distância, mesmo ele, preserva em si a capacidade de resistência. Mesmo na sua aparente resignação às pancadas que lhe eram dadas pelos guardas, ainda ali havia uma perseverança na vida. O que não se pode esquecer é que a exceção guarda também uma dimensão positiva, pois se o poder se estende globalmente sobre vida, a própria insubordinação se difunde socialmente, inclusive na vida supostamente nua, generalizando as condições do antagonismo (Cocco, 2009).

Em resposta ao vazio da vida inumana que Agamben descreve, o pensamento de Deleuze traça uma resposta positiva. Em vez de vazio, o limiar da vida é sempre pleno. É a partir desta perspectiva que se pode afirmar a vida dos muçulmanos. Desprovidos da energia mínima para falar ou para andar, sem ânimo para se defender dos ataques, eles são a prova viva, o testemunho absoluto do horror dos campos de concentração. Ao lado do poder, diz Negri, autor que segue a tradição spinozista, há sempre potência e ao lado da dominação há sempre a insubordinação.

É justamente contra a vida reduzida e diminuída que se insurgem os refugiados e os migrantes, ou melhor, os sujeitos em fuga. É contra a redução do corpo ao limite, à sua quase neutralização, que irrompem os êxodos, diásporas e fugas. É contra a cidadania baseada na vida mínima, homologada pelo Estado, que se luta. E a insurgência já é o próprio gesto da fuga. 
Dizer que os refugiados lutam por sobreviver, e que sobrevivem por superar a dor ainda é pouco generoso. Os sujeitos em fuga não superam nada, nem nada transpõem. O que há é mesmo algo que os supera. Mas não é nem passivamente que se faz essa transposição, nem tampouco ativamente. É um movimento novo, de produção de si (do ser). Este gesto de fuga já é ampliação da vida, alargamento do território existencial e expansão do corpo para muito além dos limites da sua suposta nudez.

A cicatriz não enuncia apenas o sofrimento, os golpes de dor ou o trauma inscrito no espírito, mas vai enunciar, na fuga, novos caminhos para a emergência de novas subjetividades, novas formas de vida, novos modos de associação e cooperação. É um traçado de novos territórios. Os deslocamentos forçados são, eles mesmos, deslocamentos geográficos, redefinição de fronteiras e novos espaços de exercício da soberania e de resistência. Assim como não há um corpo que seja totalmente natural, totalmente nu, não há fronteira ou território que não seja movediço.

Os deslocamentos não são apenas o efeito negativo e reativo da opressão e da violência. São também a expressão dos corpos lutando para ampliar a vida e os direitos. Na fuga, não é apenas o corpo vivendo no limite que se desloca, mas a própria potência do ser que se lança a novas fronteiras. Não apenas a vida por um fio que resiste contra a morte, mas é a vida que se constitui como acréscimo de vida, produção de vida que excede, na sua luta por libertação, como potência constituinte de vida, territórios e de direitos. E de democracia. Porque é por democracia, afinal, que se luta e que se foge.

A fuga, movimento simultaneamente negativo e positivo, como recusa e afirmação, contém uma força extraordinária, pois é uma forma de se produzir a resistência contra a opressão, tirania e exploração. Neste sentido, pode-se afirmar, então, que os refugiados, migrantes e deslocados - os sujeitos em fuga - são uma ameaça constante de desestabilização das hierarquias e divisões globais de que depende o poder capitalista global e, por isso, a fuga é resistência. E neste sentido, há uma crise que é pura afirmação.

A experiência da fuga, dizem Hardt e Negri, é como um treinamento para o desejo de liberdade. Ainda que os refugiados - mas também grande parte dos migrantes e dos sujeitos que fogem - sejam movidos pela necessidade de escapar da violência pura, da fome ou privação, eles carregam consigo o desejo positivo 
de riqueza, paz e liberdade (2005, p. 176). Fugir da insegurança constante é uma boa maneira, dizem eles, de se preparar para resistir à opressão, às formas exploração do trabalho e à apropriação de toda a riqueza comunitária (incluindo todo o aspecto imaterial, como relações, cooperação, afeto, conhecimento, etc.).

Isso não significa, é preciso insistir, em suavizar o caráter trágico dos fatos. Significa, sim, ressaltar que apesar de toda pobreza e da falta de recursos materiais, essas pessoas efetivamente dispõe de uma enorme riqueza em seus conhecimentos e poderes de criação. O migrante, o refugiado, enfim, o sujeito fuga é a figura emblemática de uma ontologia da produção, em que a resistência é antecedente ao poder. A resistência que vem primeiro, eis que antecede à própria individuação dos sujeitos que a exercem ${ }^{285}$. Há, portanto, outra tradição política que percebe, no sujeito em fuga, as linhas de luta por democracia e por um novo sujeito político.

Resistência em todas as suas formas, do modo como for possível, ainda que seja preciso recuar, recusar, fugir, nomadizar, fazer pactos. Neste sentido, a resistência nunca será uma celebração ao sacrífico ou à morte, mas sim a afirmação máxima do desejo e da vida. É preciso criar armas que não sejam apenas destrutivas, mas sejam elas próprias formas de poder constituinte, armas capazes de construir a democracia e derrotar os exércitos do Império. Não se trata de tomar o poder e comandar os exércitos, mas de destruir sua própria possibilidade.

O que importa menos na fuga é o seu caráter involuntário, pois a fuga já é resistência e como tal é potência ontológica. Apesar de toda dor que existe na involuntariedade da fuga, a distinção que se faz entre migração forçada ou espontânea serve apenas como armadilha. Todo sujeito que foge, mesmo que movido pela iminência de aniquilamento, deseja sua fuga: foge porque deseja viver e assim afirma seu desejo. E, neste sentido, não se fala mais em mera sobrevivência: é “mais vida”, uma vida maior, adicionada de outros movimentos, expansões, alianças.

${ }^{285}$ CORSINI, Leonora “OO Êxodo constituinte: multidão, democracia e migrações”. Tese de doutorado defendida na Escola de Serviço Social da Universidade Federal do Rio de Janeiro (2007). 
O refugiado congolês que foge, por exemplo, agencia, em sua fuga, novas forças, um novo pensamento, um povo inteiro (na forma da diáspora, por exemplo) no lugar do estado-parasita e de sua guerra incessante de retroalimentação. De certo modo, pode dizer que a democracia hoje assume também a forma de subtração, fuga, êxodo da soberania. Êxodo como fuga, mas sempre como resistência ativa, guerra de retaguarda contra as forças perseguidoras da soberania (Negri e Hardt, 2005).

Não é correto dizer, portanto, que a falte voz aos refugiados. Quem não pode dizer sobre si é o regime de terror do biopoder e por isso as guerras são narrativas fragmentadas, explicadas como questões locais, como disputas entre grupos, batalhas étnicas ou insurgências terroristas. É ao poder que falta voz e a capacidade de dizer sobre si: não há no vocabulário humanitário nada sobre o terror do capitalismo e sobre os genocídios que se pratica em seu nome. Nada que possa macular os relatórios assépticos que reportam a “crise dos refugiados”. Não há sangue nos balanços e reports, ainda que seja crescente o número de vítimas, de pessoas deslocadas, de ativistas presos, de desaparecimentos, da repressão a jornalistas, etc.

Por isso, as fugas são narradas como vitimas se deslocando e como crise. O corpo, sempre visto como uma individualidade ameaçada. E a vida, como uma benção sagrada, que teria direitos concedidos pelo soberano apenas pelo fato de existir. Fragmentação da realidade para mascarar a violência, diminuir a vida e docilizar os corpos. Neutralização de qualquer forma de insurgência, ainda e sobretudo, quando a insurgência é desesperada; porque no desespero reside uma grande força.

\section{4}

\section{A vida maior contra a sobrevivência}

Se seguimos a crise dos refugiados apenas em sua dimensão reativa, e a vida apenas como sobrevida, veremos a crise também como criação e a vida como produção incessante de excedente de mais vida e a dor como a possibilidade de pensar o mundo em sua realidade. Insistimos que não se trata de recusar a tragédia e a dor, mas sim recuperá-las do vazio e da impotência e recuperá-las da única narrativa que lhe dá o poder, que é a da vitimização passiva. 
Acusamos a razão humanitária -especialmente por sua tentativa de neutralizar a vida como resistência e por sua tentativa em gerir a vida como uma generalidade -- para apontar sua fraqueza, seu limite conceitual e seu "equívoco ontológico”. E, sobretudo, para verificar como a razão humanitária é parte componente e ativa dos massacres. E não somente por causa da ambiguidade das ações das agências e organizações (estatais, não estatais ou supra-estatais) de proteção dos refugiados, ou porque, em seu nome, se justificam as intervenções militares.

No limite, a razão humanitária, pela indistinção das vidas e generalização do sofrimento, se articula com os dispositivos mais sofisticados e com os mais arcaicos e brutais de controle, contenção e exploração. A razão humanitária se articula com os dispositivos binários do estado, propondo continuas distinções e dualidades. E se tal articulação é contingente, como é o caso dos dispositivos de poder, em geral, trata-se de ver então o momento ou o local em que a retórica das razões humanitárias investe contra a vida.

A razão humanitária que move o direito internacional dos refugiados pressupõe a vida nua como o critério de justiça. Supõe a equivalência entre as vidas a partir do sofrimento, seja no tempo passado ou na possibilidade futura, propondo então uma comunidade moral em que a vitimização (mesmo que apenas virtual) torna-se a condição de igualdade entre todos os indivíduos. Neste sentido, a inscrição na humanidade se faz justamente pela eleição do sofrimento como condição de igualdade - todos podem sofrer - e faz da nudez da vida o principal fato político. Dessa forma, a inscrição de alguns indivíduos como "humanos” só pode ocorrer quando a vida nua encontra-se na iminência do aniquilamento. Contra todas as evidências do dia-a-dia, porém, omite-se que a violência e a miséria não atingem igualmente a vida dos indivíduos.

O problema em relação à proteção "humanitária” da vida nua é que ela se sustenta sobre a piedade, isto é, no amor à vida, mas a vida fraca, doente, reativa, o que equivale, em última instância, à despontecialização da resistência. Capturado pelo engodo da sacralidade do direito à vida, o humano percebe a vida como concessão do (poder) soberano. A experiência das lutas - inclusive a dos refugiados e imigrantes - entretanto, mostra que é a própria vida que reclama seus direitos. Neste sentido, o direito originário não é o direito à vida, mas o direito à resistência; ela é sempre primeira, como constituinte mesmo da vida, como 
ontologia do humano. É ela quem cria, garante e amplia todos os demais direitos, inclusive o que se chama direito à vida.

Estes mesmos direitos naturais, eternos e imutáveis, criados para salvar o humano, nos condena a uma decisão transcendente sobre a nossa qualidade "humana”, e isso deveria ser suficiente para concluirmos que há um conceito de "humano" a ser superado. Neste sentido, a alteridade dos refugiados e dos mirantes - aquilo que é a riqueza contida na criatividade e potência dos pobres e nômades - é a força capaz de resistir, transmutar valores e criar novas comunidades e novos direitos.

Acima de tudo, a crítica às razões humanitárias é a tentativa de reconhecer a incrível força da fuga e reconhecer a justiça da sobrevivência. Não permitir que a sobrevivência seja a diminuição da vida, mas, ao contrário, seja o mínimo necessário para o máximo da vida. Empreender uma luta contra a “quase vida” é não apenas um objetivo, mas a escolha de um método: um modo de pensar a crise em todas as suas dimensões. Método que não se separa do objeto e meios que não se separam dos fins.

\section{5}

\section{Cidadania como potência e o direito dos mais fortes}

O estatuto político e jurídico dos sujeitos que fogem, não é definido pelo soberano: a cidadania e o direito são terrenos de luta e os refugiados e migrantes afirmam-se como sujeitos e cidadãos quando exercem seu direito de resistência. Neste sentido, é preciso pensar a justiça como terreno atual das lutas e da força dos movimentos, ou da produção biopolítica da resistência. Assumimos, então, que a resistência antecede o poder, no sentido que é o poder que se reorganiza para bloquear a resistência. Trata-se, portanto, de pensar um direito que se produz na materialidade das lutas e da vida. O fundamento deste direito não está em um modelo transcendente, mas sim no próprio exercício do direito, como expressão de uma potência singular.

É preciso afirmar então, no caso dos sujeitos em fuga, a força constituinte e ontológica de sua fuga. Isso significa sustentar o caráter antecedente e constituinte da fuga, e, em seguida, o direito como terreno imanente às lutas dos refugiados, de 
onde emergirá, assim, uma nova narrativa sobre o direito e sobre a justiça. Neste terreno de lutas, a fuga dos refugiados é produção de resistência, de subjetividades: produção do ser. E o direito surge como fruto da potência constituinte.

Isso quer dizer que o direito dos refugiados tem como origem a produção de que é capaz o próprio êxodo dos refugiados, considerando sua potência constituinte de fazer emergir novas subjetividades. A normatividade baseada no contratualismo ou no paradigma positivista dá lugar, portanto, ao direito fundado na ontologia do êxodo e dos deslocados. Uma normatividade que segue a imanência da produção ontológica dos novos sujeitos constituídos em sua luta por uma vida maior. É de uma vida maior que trata este direito e de um direito mais forte que se trata.

Distantes tanto da complacência da vitimização, quanto da romantização do herói (Mezzadra 2005), o gesto da fuga é um processo de êxodo em busca da liberdade e, simultaneamente, é esta mobilidade que compõe a base de muitos movimentos sociais, mesmo aqueles com os quais a migração não tem uma relação direta. O direito de fugir não está preso à perspectiva biopoder, mas no sentido de práticas sociais concretas, que envolvem, ao mesmo tempo, a busca de igualdade e a recusa de integração ou assimilação.

Trata-se de uma recusa da cidadania subordinada, em nome da construção de uma cidadania que Mezzadra (Ibidem) denomina “cidadinização”, isto é, uma cidadania de fronteira. O desafio é, portanto, perscrutar a vida não no limiar, mas no terreno onde ela emerge constitutivamente, isto é, na materialidade ontológica da resistência, ainda que na forma da recusa, da fuga ou da negação.

Em vez da vida no limiar ou da existência sob risco, o direito do refugiado está situado na resistência. E a dignidade da vida, fundada no humano como generalidade e na vida como abstração, tem a fuga como fundamento. No caso das pessoas que atravessam fronteiras em busca de segurança, paz, justiça e melhores condições de vida, a fuga é a própria dignidade. Deste ponto de vista, é a vida como resistência que é objeto de proteção e é justamente este movimento - de fuga e resistência - que constitui a dignidade da vida e a própria vida. O direito de fugir da violência, de resistir à opressão, de desejar uma vida sem miséria, tudo isso é o que constitui o direito originário, aquele que precisa de proteção. É a vida em seu esforço de resistir que faz constituir a vida; é o que define a ontologia do 
humano. É a resistência - e o desejo subjacente à resistência - que cria, garante e amplia todos os demais direitos, inclusive o que se chama "direito à vida”.

O direito de refúgio se afirma, portanto, em ato. Não apenas a partir de uma perspectiva do estado acolhedor, mas do ponto de vista da pessoa que foge, pois fugir, neste caso, aponta não apenas para a violência como um fato e uma causa. Aponta também para o desejo em resistir, assim como o desejo em constituir apesar e através da fuga - novas relações, novas comunidades, novos mundos. O direito, assim, deve ser entendido como a capacidade, o desejo e a potência de fazer o próprio direito existir. Direito dos mais fortes. 


\section{Conclusões}

"Resiste-se somente quando se tem a capacidade de construirse como sujeito, e é somente assim que se pode falar em estratégias constituintes, em constituição genealógica do sujeito, em êxodo."

Antonio Negri ${ }^{286}$

"O gordo de cartola vive nas costas dos pobres que ele esmaga, é justo. Mas que o gordo seja o capitalismo, não é totalmente justo. [...] A imagem não está completa. Por isso não é boa. $O$ capitalismo é um sistema de dependências que vão de dentro para fora e de fora para dentro. De cima para baixo e de baixo para cima. Tudo é dependente, tudo está encadeado. O capitalismo é um estado do mundo e da alma."

Franz Kafka ${ }^{287}$

Tratamos da crise em duas perspectivas: uma primeira que é a crise em sua dimensão negativa, representada não apenas pelo extraordinário número de pessoas deslocadas no mundo em razão de guerras e perseguições, mas pela guerra generalizada, incluindo a guerra contra os refugiados e migrantes; a segunda, que é a crise em sua dimensão afirmativa ou positiva, produzida pelo gesto dos sujeitos em fuga, recusando a guerra, ao mesmo tempo em que afirmam a vida. A partir destas duas perspectivas, podemos desenvolver nossas conclusões em alguns breves pontos:

1. A crise é generalizada. Mais de 60 milhões de pessoas deslocadas forçadamente, dentre os quais pelo menos cinco milhões se deslocaram apenas na primeira metade do ano de 2015. Pelo menos três milhões de pessoas aguardam

${ }^{286}$ NEGRI, A. “Cinco lições sobre Império”. Rio de Janeiro: DP\&A, 2003, p.136 .

287 JANOUCH, Gustav. Conversas com Kafka., São Paulo: Novo século, 2008, p. 184. 
decisão para seus pedidos de refúgio ${ }^{288}$. Contudo, a crise está concentrada especialmente na parte sul do mundo, onde está a grande maioria dos refugiados e solicitantes de refúgio. É também na parte sul do mundo que concentra os maiores fluxos migratórios: ao contrário das imagens que se divulgam, a migração sul sul é o maior fluxo no mundo (37\% do total), superior à migração entre sul e norte (35\%), correspondendo a 90,2 milhões de pessoas em deslocamento ${ }^{289}$.

Não apenas de deslocados a crise é feita, ou de vítimas fatais, feridos e mutilados. A crise é feita também a forma de gestão e de governo: ampliação das fronteiras e dos muros e obstáculos, perseguição violenta aos refugiados e migrantes, processos burocráticos que mal dissimulam o preconceito e o racismo como elemento fundamental do regime do biopoder, dentre outras medidas. O principal elemento desta crise, porém, é a gestão da iniquidade: a parte mais pobre do planeta suporta a maioria absoluta dos refugiados. E isso não é um dado secundário. A distinção entre refugiados e solicitantes é continuamente marcada e construída, para impedir o acesso dos grandes fluxos nos países do norte. A crise dos refugiados surge como retórica justamente quando os sujeitos estão determinados a globalizar as lutas, ou seja, forçadamente incluir no norte (sobretudo na Europa) as suas demandas por paz, segurança e democracia.

O que chamamos aqui de “crise” é, no entanto, a recomposição de estratégias por parte do biopoder, isto é, uma forma reativa de conter fluxos e irrupções de desejos por liberdade e expansão. Lamentavelmente, esta contenção não é feita apenas pela repressão, mas também pela captura da empatia e da sensibilidade coletiva, inclusive pela produção de um conceito de vida que é sempre diminuída e pela criação de uma cidadania que é sempre subordinada.

2. A “crise de refugiados" não é apenas um modo de distinguir entre refugiados inocentes e refugiados falsos, ou entre refugiados e migrantes, mas é também um modo de fazer da distinção um dispositivo permanente e contínuo de produção de verdade (saber e poder). Não se trata tampouco de incluir alguns (os refugiados) em prejuízo de outros (os migrantes, por exemplo), mas de incluir todos, de modo diferenciado. E se trata principalmente de fazer incluir de uma

288 "Millions in asylum claim backlog”. IRIN. Londres, 20/06/2016. (Disponível em http://www.irinnews.org/maps-and-graphics/2016/06/20/millions-asylum-claim-backlog) (Último acesso em 13/07/2016).

289 “Global migration data analysis centre - 2015 Global Migration Trends”. International Organization for Migration. Berlim. Abril de 2016. 
determinada maneira. Operação de positividade do poder, produzindo subjetividades.

A retórica da crise é o pretexto para a ampliação dos investimentos em segurança e repressão nas fronteiras, mas, principalmente, para a construção e ampliação das fronteiras: os traços de “anormalidade” também justificam a ampliação da definição do que é risco e de quais são as figuras que hoje representam riscos. A crise é a própria retórica, ou melhor, o recrudescimento da violência.

Neste sentido, é a justificativa para ampliar a própria definição de migrante, de refugiado ou de terrorista, ou melhor, da anormalidade que tais figuras portam e das linhas de anormalidade presentes em tantas outras formas de insubordinação. É preciso, contudo, insistir que não se trata apenas de criar barreiras, mas produzir "saber" e "verdade".

Os dispositivos do biopoder, em sua pretensão de bloquear o movimento dos indivíduos e em sua constante operação de distinguir, selecionar e classificar, não age simplesmente em termos de escolha: um em detrimento de outro, ou de incluir uns, enquanto exclui outros. Não é apenas separar os migrantes dentre os refugiados, excluindo aqueles e incluindo estes. Não é tanto a exclusão que interessa, mas a técnica, o procedimento que seleciona e exclui; é esta mecânica do poder que interessa, assim como as técnicas de medicalização da sexualidade, da loucura ou da delinquência interessaram antes.

Ao mesmo tempo, não interessa apenas o mecanismo de inclusão e exclusão e, em especial, o que se exclui. Interessa ver que, de certo modo, nada nem ninguém fica excluído, e que o mecanismo de separação ou distinção serve como classificação, atribuindo a cada um seu próprio modo de produção. Não se pode tomar tais mecanismos - que evidentemente são dispositivos de poder, ou, de outro modo, dispositivos biopolíticos - apenas por seus efeitos negativos, de repressão, recalcamento e exclusão.

Da mesma forma como a resistência não se toma apenas pela reação negativa, o poder igualmente se realiza também pela positividade, pela produção de realidade e de verdade. O que interessa ao poder, sobretudo, não é impedir a ação dos sujeitos, mas sim gerir suas vidas, controlar suas ações e extrair o máximo de suas potencialidades. Mesmo quando pensamos nos refugiados ou nos pobres em geral, é preciso ver como estão todos, a seu modo, incluídos nos 
mecanismos de extração do trabalho vivo, ainda que o trabalho vivo tenha como simples condição a cidadania ou a mera existência na cidade. Ou mesmo a mobilidade.

Esta dinâmica dos mecanismos de poder pretendem ao mesmo tempo uma intervenção econômica - aumento de produção e de extração - e política reduzindo a capacidade de revolta e insubordinação, tornando politicamente dóceis os sujeitos. Mais do que impedir os movimentos, o poder e seus mecanismos visam normalizar os sujeitos e evitar a força irruptiva e subversiva que eles provocam, inclusive e sobretudo, atuando sobre as conexões entre os sujeitos, sobre suas redes de cooperação e sobre as individualidades. Assim, esses dispositivos produzem subjetividades, seja demarcando os limites da legalidade e da normalidade, seja impondo aos sujeitos a internalização da culpa ou ainda através da simples segregação.

Ao mesmo tempo, os mecanismos de poder justificam e ampliam sua própria capacidade de atuação. A demarcação do limite entre refugiados e migrantes, vítimas e mentirosos, nacionais e estrangeiros, por exemplo, não funciona apenas para que se faça aplicar sobre estes últimos uma repressão específica ou um poder diferenciado. Trata-se de criar condições para que se soterrem alteridades “ameaçadoras” e potenciais irrupções de insubordinação, mesmo no interior do que talvez se possa chamar de subjetividade do "normal” ou do "nacional".

E ainda assim, mesmo que a ação de poder não seja capaz de neutralizar completamente a insurgência dos sujeitos, ele será capaz de manter o jogo de forma a incluir em seus cálculos a força desta resistência, driblando-a ou capturando-a, produzindo conhecimento e verdade. Mas sempre em uma dinâmica de estratégias, em que constantes inversões tentam imobilizar a outra parte ou ganhar um passo adiante. Tanto em sua dimensão disciplinar ou de controle, ao poder e aos seus mecanismos nunca interessou apenas agir sobre aqueles pontos específicos ou sobre os sujeitos que as fazem eclodir. Interessa, em vez disso, criar vastas redes capilarizadas, descentralizadas e diluídas de controle e sujeição, que possam prevenir e intimidar novas implosões, se possível, dentro da subjetividade de cada sujeito, ou melhor, na forma de subjetivação dos indivíduos.

3. Os fluxos de refugiados e migrantes, ou o fluxo dos sujeitos em fuga, são fluxos singulares e igualmente fluxos de singularidades. Dizemos isso não para 
acusar o universalismo e a abstração do que seria oficialmente o direito de refúgio e sua pretensão em determinar a verdade sobre os sujeitos, mas para dizer que a singularidade do fluxo anuncia sua própria verdade. Quanto a isso, queremos dizer que em oposição a um poder que reclama a confissão individual das vítimas, há os fluxos - fugas, êxodos e principalmente diásporas - que enunciam sua própria verdade.

E é a própria fuga que dá o valor da recusa, que atribui verdade aos motivos do deslocamento. Isso quer dizer que é a fuga que qualifica o "fundado temor de perseguição” ou a “a grave e generalizada violação de direitos humanos”. Em última análise, é a fuga que qualifica a dignidade da vida, o valor da liberdade e da segurança.

Por isso, insistimos que a crise tem a sua dimensão positiva e é determinada afirmativamente pela fuga. E isso implica em dizer que além ou entre as várias classificações - refugiados inocentes, refugiados falsos, migrantes, deslocados forçados, ilegais, etc. -- há um outro sujeito que enuncia sua própria dignidade na fuga.

4. O Estatuto dos refugiados - ou dos sujeitos em fuga - é o estatuto da vida como afirmação e resistência e não da vida como sobrevivência. E a fuga é a condição de nossa existência no regime da soberania imperial e da guerra generalizada. Os refugiados e migrantes, contudo, apesar de toda a violência e de todas as guerras, estão vivos e sua fuga é expressão da vida e não da morte. Ainda que se oponham a eles todas as barreiras, continuarão a fugir e insistirão em viver.

Se os refugiados são a expressão negativa da crise - ao menos desta atual crise --, talvez o Congo possa ser considerado o sintoma e o paradigma da guerra global, provando que a guerra é, ao mesmo tempo, brutal e cotidiana e que os massacres sobreviveram à transição da modernidade para a soberania do biopoder, não como último resquício de irracionalidade, mas como violência "legítima” do biopoder, como expressão da violência em que vivemos diariamente. E, ainda, que o poder, a guerra e também as fronteiras são móveis e nômades. A "crise dos refugiados”, isto é, a mais recente expressão da guerra contra os refugiados e migrantes, nos demonstra que os próprios sujeitos são marcados com(o) as fronteiras - por sua cor, classe, origem, pelo passaporte que apresentam ou pelo desespero que carregam. 
O que nos interessa é insistir que a despeito de toda dor e de toda miséria, a fuga - na forma do deslocamento, das diásporas, do êxodo -- são experiências de recusa -- à morte, à violência e ao poder de matar - e igualmente são experiências de afirmação da vida. O Congo, neste sentido, é também o paradigma da resistência e da afirmação da vida, na forma da fuga e das diásporas. A crise dos refugiados é, primeiramente, esta força constituinte que altera a ordem do mundo e que faz o próprio mundo fugir.

Se a guerra é a expressão da "crise dos refugiados”, a resistência e a vida são expressão dos “refugiados como crise”. E se a guerra surge como paradigma destes tempos, a fuga e o êxodo surgem como paradigma da vida como resistência e produção do tempo por vir, que é o tempo constituído na fuga e pela fuga. O sujeito em êxodo -- incluindo o êxodo dentro e a partir do próprio corpo, como na miscigenação -- surge como figura emblemática de uma ontologia da produção, em que a resistência é antecedente ao poder. A resistência que vem primeiro, eis que antecede à própria individuação dos sujeitos que a exercem ${ }^{290}$.

5. Inspirados por Silvio Pedrosa ${ }^{291}$, dizemos que todos somos refugiados; mas não dizemos isso como parte de uma retórica humanizante. Afirmamos que somos refugiados como uma declaração que, em primeiro lugar, constata e exprime solidariedade frente a uma tragédia que consideramos exterior, mas, sobretudo, que adquire toda uma potência performativa quando descobrimos, não como observadores, mas como viventes, que a fuga é a condição generalizada da subjetividade e que a figura objetiva do refugiado é paradigmática do nosso tempo. Quando é possível estender a mão para aqueles que fogem, sem imaginálos como pobres vítimas do mundo, mas nos reconhecendo neles, já diferentes, em nossa admiração de sua coragem diante da vida e compreendendo que o que temos em comum é a potência que vemos explodir neles através dessa coragem alegre com que eles desejam, ainda e apesar de tudo, viver.

Querem os pobres (e por pobres o capital entende e reduz todo aquele que é perigoso para a sua dinâmica: índios, mulheres, negros, homossexuais, em suma, a multiplicidade) apenas enquanto presas e temem, sobretudo, que eles possam se

290 Como bem destacou Leonora Corsini em sua tese de doutorado “O Êxodo constituinte: multidão, democracia e migrações”, defendida na Escola de Serviço Social da Universidade Federal do Rio de Janeiro (2007).

291 Texto publicado por Silvio Pedrosa no $\quad$ Facebook (https://www.facebook.com/shgpedrosa/posts/1057524690926969) 
tornar predadores. Pois o grande medo é que no êxodo de todos dias que é a vida no nosso tempo, os pobres possam, à maneira de George Jackson ${ }^{292}$, procurar uma arma e reivindicar a sua humanidade sem ter que suportar a condescendência dos que os desejam humanizar através da inclusão que identifica o ainda-não-humano como humano a normalizar. Essa reivindicação de humanidade como relação é, afinal, aquilo que entendemos (ou deveríamos entender) por libertação (os escravos tão bem o souberam). Ninguém a concede, é preciso rugir, como os animais, para consegui-la ${ }^{293}$.

${ }^{292}$ George Lester Jackson, nascido em setembro de 1941, se tornou um ativista pela liberdade dos negros nos Estados Unidos da América, depois de ser preso, acusado pelo roubo de \$ 0,70 de um posto de gasolina. Sentenciado a um ano de prisão, ficou anos preso, até ser morto em uma tentativa de fuga, em agosto de 1971. Marxista, foi membro dos "Panteras Negras", fundou o grupo "Black Guerrila Family" e se tornou um dos "Soledad Brothers".

$\begin{array}{llllll}{ }^{293} \text { Texto publicado por } & \text { Silvio } & \text { Pedrosa } & \text { no } & \text { Facebook }\end{array}$ (https://www.facebook.com/shgpedrosa/posts/1057524690926969). 


\section{Referências bibliográficas}

AGAMBEN, Giorgio. Homo Sacer. O poder soberano e a vida nua. Belo Horizonte: UFMG, 2002. . Estado de Exceção. São Paulo: Boitempo, 2003.

ARENDT, Hannah. Origens do Totalitarismo. Anti-Semitismo, Imperialismo, Totalitarismo. São Paulo: Companhia das Letras, 1998. . Sobre a Revolução. Lisboa: Relógio D’água, 2001.

BALIBAR, Étienne. Politics and the Other Scene. Verso, London: 2002, 2011. BLANCHOT, Maurice. “L' Espèce humaine” in L'entretien infini. Paris: Gallimard, 1969.

COCCO, Giuseppe. Korpobraz: por uma política dos corpos. Rio de Janeiro: Mauad X, 2014.

DELEUZE, Gilles. Sobre as sociedades de controle. In: Conversações - 19721990, Rio de Janeiro: Ed. 34, 1992.

. Nietzsche e a filosofia. Porto: Rés-Editora, 2001. Foucault. São Paulo: Brasiliense, 2005.

DELEUZE, Gilles e GUATARRI, Félix. $O$ Anti-Édipo: capitalismo $e$ esquizofrenia. São Paulo: Ed. 34, 2010.

DELEUZE, Gilles e PARNET, Claire. Diálogos. Lisboa: Relógio D`água, 2004.

DREYFUS, H.L. \& RABINOW, PAUL. Michel Foucault, uma trajetória filosófica. Rio de Janeiro: Editora Forense, 2013.

FASSIN, Didier. Humanitarian reason: a moral history of the present. University of California Press, California, 2012.

FOUCAULT, Michel. Em defesa da sociedade. São Paulo: Martins Fontes, 1999. 
Microfísica do Poder. Graal, 2004, São Paulo.

. A verdade e as formas jurídicas. Rio de Janeiro : NAU Editora, 2005.

- Estratégia, Poder-Saber. Ditos e Escritos IV. Rio de Janeiro: Forense Universitária, 2006.

. História da sexualidade (vol. I): a vontade de saber. 18. ed. Rio de Janeiro: Edições Graal, 2007a.

. Segurança, Território, População. São Paulo: Martins Fontes, 2008.

. Nascimento da biopolítica: curso no Collège de France: (19781979). São Paulo: Martins Fontes, 2008b.

. Ética, Sexualidade, Política. Ditos \& Escritos V. Rio de Janeiro: Forense Universitária, 2010.

. Genealogia da Ética, Subjetividade e Sexualidade. Ditos \& Escritos

IX. Rio de Janeiro: Forense Universitária, 2014.

GROS, Frédéric. Estados de Violência. Ensaios sobre o fim da guerra. São Paulo: Editora Idéias e Letras, 2009.

DIDI-HUBERMAN,Georges. A sobrevivência dos vagalumes. Belo Horizonte, Editora UFMG, 2011.

GUIMARAENS, Francisco de. Direto, ética e política em Spinoza. Rio de Janeiro: Lumen Juris, 2011.

HARDT, Michel e NEGRI, Antonio. Multidão. Guerra e democracia na era do Império. Rio de Janeiro: Record, 2005.

. Império. Rio de Janeiro: Record, 2006.

. Commonwealth. Cambridge: Harvard University Press, 2009.

LEVI, Primo. É isto um homem? Rio de Janeiro: Rocco, 1988. 
LLOSA, Mario Vargas. O sonho do Celta. Rio de Janeiro: Objetiva, 2011.

MEZZADRA, Sandro. Derecho de fuga, Madrid: Traficantes de Sueños, 2005

MEZZADRA, Sandro e NEILSON, Brett. Border as Method, or, the multiplication of labor. Durham and London: Duke University Press, 2013.

NEGRI, Antonio. Exílio. São Paulo: Ed. Iluminuras, 2001.

Poder constituinte: ensaio sobre as alternativas da modernidade. Rio de Janeiro: DP\&A, 2002.

. Cinco Lições sobre Império. Rio de Janeiro: DP\&A, 2003.

.. Biocapitalismo: entre Spinoza e a contribuição política do presente. São Paulo, Ed. Iluminuras, 2015.

NEGRI, Antonio e DUFOURMANTELLE, Anne. Negri on Negri. Routledge, New York/London, 2002.

NEGRI, Antonio e COCCO, Giuseppe. GlobAL: biopoder e lutas em uma Amérca Latina globalizada. Rio de Janeiro: Record, 2005.

PACHECO, Anelise, COCCO, Giuseppe e VAZ, Paulo (organizadores). O trabalho da multidão: império e resistências. Rio de Janeiro: Gryphus: Museu da República, 2002.

PAPADOPOULOS, Dimitris;STEPHENSON, Niamh \& TSIANS, Vassilis. Escape routes. London: Pluto Press, 2008.

PELBART, Peter Pal. Vida Capital. Ensaios de biopolítica. São Paulo: Iluminuras, 2003.

REVEL, Judith. Dicionário Foucault. Rio de Janeiro: Forense Universitária, 2011.

SPINOZA, Baruch. Tratado Teológico Político, São Paulo: Perspectiva, 2014. 
VAN HEAR, Nicholas. New Diasporas: the mass exodus, dispersal and reagrouping of migrant communities. University College London Press, London, 1998

\section{Publicações}

CAVA, Bruno \& MENDES, Alexandre Fabiano. “A vida dos direitos - violência e modernidade em Foucault e Agambem”, Revista Filosofia Polícia do direito, Rio de Janeiro: Núcleo de Pesquisa Lyrian, Agon, 2008.

\section{Teses e dissertações.}

CORSINI, Leonora. “O Êxodo constituinte: multidão, democracia e migrações”. Tese defendida na Escola de Serviço Social da Universidade Federal do Rio de Janeiro (2007).

MOREIRA, Julia Bertino. "Política em relação aos refugiados no Brasil (1947 2010)”. Tese defendida no Instituto de Filosofia e Ciências Humanas da Universidade Estadual de Campinas (2012),

WALDELY, Aryadne B. "Narrativas da 'vida em fuga': a construção políticajurídica da condição de refugiado no Brasil”. Dissertação de Mestrado. Programa de Pós-graduação em Direito da Faculdade Nacional do Rio de Janeiro, defendida em maio de 2016.

\section{Manuais}

"Manual de procedimentos e critérios para a determinação da condição de refugiado, de acordo com a Convenção de 1951 e o Protocolo de 1967 Relativos ao Estatuto dos Refugiados”, Genebra, ACNUR, 2011.

\section{Artigos}

AGIER, Michel. "Refugiados diante da nova ordem mundial”. Tempo social, Revista de sociologia da USP. V. 18, n.2, pp. 197-215. Novembro de 2006. 
BEARD, Jennifer \& NOLL, Gregor. "Parrhesia and Credibility: The sovereign of refugee status determination”. Social \& Legal Sutides, Vol. 18(4), 455-477, 2009.

BETTS, Alexander. “Survival Migration: A New Protection Framework”. Global Governance: A Review of Multilateralism and International Organizations: JulySeptember 2010, Vol. 16, No. 3, pp. 361-382. (Disponível em http://siteresources.worldbank.org/INTRANETSOCIALDEVELOPMENT/Resour ces/244329-1255462486411/Betts_Survival_Migration.pdf).

BINGHAM, John K., in Cadernos de Debates: “Refúgio, Migrações e Cidadania”, v.5, n.5 (2010), Brasília: Instituto Migrações e Direitos Humanos.

CORRÊA, Murilo Duarte Costa. "Os direitos humanos na encruzilhada biopolítica”. Direito e Democracia, v.12, n.1, jan./jun. 2011 (disponível em http://murilocorrea.blogspot.com.br).

DOUZINAS, Costas. “As Muitas Faces do Humanitarismo”, Revista Direito \& Praxis, vol. 06. N.11, 2015, p. 375-424.

FASSIN, Didier. "La Souffrance du monde. Considérations Anthropologiques sur les Politiques Contemporaines de La Compassion”. Évolution Psichyatrique, 67, pp. 676-89. 2002.

FASSIN, Didier. "Humanitarianism as a Politics of Life”. Public Culture, 19:3. pp. 499- 520. Duke University Press, 2007.

FASSIN, Didier. "La economia moral del asilo. Reflexiones críticas sobre la ‘crisis de los refugiados’ de 2015 em Europa”. Revista de Dialectologia y Tradiciones Populares. Vol. LXX, n.2, pp.277-290, julho-dezembro 2015.

HURTADO, Michael Reed, “The Cartagena Declaration on Refugees and the Protection of People Fleeing Armed Conflict and Other Situations of Violence in Latin America”. United Nations High Commissioner for Refugees, 2013, disponível em http://www.unhcr.org/pages/4a16b17a6.html. 
KONGO, Charly. Diáspora congolesa e o nosso apelo aos irmãos brasileiros. 16 nov. 2014. (Disponível em: http://www.pordentrodaafrica.com/cultura/nossoapelo-aos-irmaos-brasileiros-por-charly-kongo).

MENDES, Alexandre. "Joaquín Herrera Flores e a dignidade da luta”. Direito e Práxis, V. 02, n. 01, 2011.

MENDES, Alexandre. "Ocupações estudantis: novas assembleias constituintes diante da crise?”. Uninomade Brasil. (Disponível em http://uninomade.net/tenda/ocupacoes-estudantis-novas-assembleias-constituintesdiante-da-crise-2/)

MEZZADRA, Sandro. “Capitalismo, Migraciones y luchas sociales. La mirada de la autonomia”. Nueva Sociedad $\mathrm{N}^{-}$237, janeiro-fevereiro de 2012, ISSN: 02513552 (disponível em www.nuso.org).

REIS, Rossana Reis Rocha \& MOREIRA, Julia Bertino. "Regime Internacional para refugiados: mudanças e desafios”. Revista Sociologia e Política, v. 18, n.37, pp. 17-30, Curitiba, outubro de 2010.

SOUZA, Fabrício T. “O êxodo dos refugiados e o direito a resistir”. Revista Direito e Praxis, V. 5, n, 9, pp. 101-117, 2014.

SOUZA, Fabrício T. et al.” Migração como crime, êxodo como liberdade”. REMHU: Revista Interdisciplinar de Mobilidade Humana, vol. 23, n. 45, pp. 235247, 2015.

SOUZA, Fabrício T. et al "Cartagena + 30: pelo fortalecimento do direito de refúgio”. Cadernos de Debates Refúgio, Migração e Cidadania, v.9, n. 9, pp. 3152. Instituto Migrações e Direitos Humanos e ACNUR, Brasília, Dezembro de 2014. 